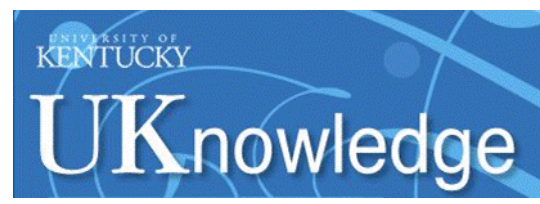

University of Kentucky

UKnowledge

Theses and Dissertations--Earth and Environmental Sciences

\title{
THE FORESTRY RECLAMATION APPROACH: MEASURING SEDIMENT MASS ACCUMULATION RATES IN RECLAIMED MINE LANDS AND NATURALLY REGENERATED LOGGED FORESTS OF EASTERN KENTUCKY
}

William E. Bond

University of Kentucky, zaku399@hotmail.com

Digital Object Identifier: https://doi.org/10.13023/etd.2019.382

Right click to open a feedback form in a new tab to let us know how this document benefits you.

\section{Recommended Citation}

Bond, William E., "THE FORESTRY RECLAMATION APPROACH: MEASURING SEDIMENT MASS

ACCUMULATION RATES IN RECLAIMED MINE LANDS AND NATURALLY REGENERATED LOGGED

FORESTS OF EASTERN KENTUCKY" (2019). Theses and Dissertations--Earth and Environmental Sciences.

75.

https://uknowledge.uky.edu/ees_etds/75

This Master's Thesis is brought to you for free and open access by the Earth and Environmental Sciences at UKnowledge. It has been accepted for inclusion in Theses and Dissertations--Earth and Environmental Sciences by an authorized administrator of UKnowledge. For more information, please contact UKnowledge@lsv.uky.edu. 


\section{STUDENT AGREEMENT:}

I represent that my thesis or dissertation and abstract are my original work. Proper attribution has been given to all outside sources. I understand that I am solely responsible for obtaining any needed copyright permissions. I have obtained needed written permission statement(s) from the owner(s) of each third-party copyrighted matter to be included in my work, allowing electronic distribution (if such use is not permitted by the fair use doctrine) which will be submitted to UKnowledge as Additional File.

I hereby grant to The University of Kentucky and its agents the irrevocable, non-exclusive, and royalty-free license to archive and make accessible my work in whole or in part in all forms of media, now or hereafter known. I agree that the document mentioned above may be made available immediately for worldwide access unless an embargo applies.

I retain all other ownership rights to the copyright of my work. I also retain the right to use in future works (such as articles or books) all or part of my work. I understand that I am free to register the copyright to my work.

\section{REVIEW, APPROVAL AND ACCEPTANCE}

The document mentioned above has been reviewed and accepted by the student's advisor, on behalf of the advisory committee, and by the Director of Graduate Studies (DGS), on behalf of the program; we verify that this is the final, approved version of the student's thesis including all changes required by the advisory committee. The undersigned agree to abide by the statements above.

William E. Bond, Student

Dr. Kevin M. Yeager, Major Professor Dr. Edward W. Woolery, Director of Graduate Studies 
THE FORESTRY RECLAMATION APPROACH: MEASURING SEDIMENT MASS ACCUMULATION RATES IN RECLAIMED MINE LANDS AND NATURALLY REGENERATED LOGGED FORESTS OF EASTERN KENTUCKY

THESIS

A thesis submitted in partial fulfillment of the requirements for the degree of Master of Science in the College of Arts and Sciences at the University of Kentucky

By

William Edward Bond

Lexington, Kentucky

Director: Dr. Kevin M. Yeager, Associate Professor of Earth and Environmental Sciences

Lexington, Kentucky

2019

Copyright (C) William Edward Bond 2019 


\section{ABSTRACT OF THESIS}

\section{THE FORESTRY RECLAMATION APPROACH: MEASURING SEDIMENT MASS ACCUMULATION RATES IN RECLAIMED MINE LANDS AND NATURALLY REGENERATED LOGGED FORESTS OF EASTERN KENTUCKY}

The spread of surface coal mining has resulted in loss of forests in the Appalachian region. The Forestry Reclamation Approach (FRA) was developed to provide guidance for restoring forests on reclaimed mined land. This study hypothesizes that the FRA will result in larger magnitude of sediment accumulation rates in reclaimed mine sites compared to those reclaimed using grassland reclamation. Three sediment cores and six trenches were sampled within four reclaimed mined and three previously logged sites in eastern Kentucky. Samples were processed for radionuclides, grain-size, stable isotopes $\left(\delta^{13} \mathrm{C}\right)$, and POC. LIDAR data were used to identify valley fills, while historical aerial photography was used to identify changes in vegetative cover from 1994 to 2016. Radionuclide dating was used to determine sediment accumulation rates over the previous 100 years. Results from logged sites are inconclusive. $\delta^{13} \mathrm{C}$ data for all sites fall within the range expected for forested landscapes (C3), and do not show any transitions from grassland to forests. POC data indicates that inventories and fluxes were the same for mined and logged sites. Sediment accumulation rates for reclaimed mined lands show elevated values after the implementation of the FRA, compared to grassland reclamation, thus supporting the hypothesis for previously mined sites.

KEYWORDS: Forestry Reclamation Approach (FRA), Radionuclide Analysis Sediments, Stable Isotope Analysis Sediment, Particulate Organic Carbon, Reclaimed Mines

William Edward Bond

September 20, 2019 
THE FORESTRY RECLAMATION APPROACH: MEASURING SEDIMENT MASS ACCUMULATION RATES IN RECLAIMED MINE LANDS AND NATURALLY REGENERATED LOGGED FORESTS OF EASTERN KENTUCKY

By

William Edward Bond

Dr. Kevin M. Yeager

Director of Thesis

Dr. Edward W. Woolery

Director of Graduate Studies

September 20, 2019 


\section{ACKNOWLEDGEMENTS}

I would like to thank my research advisor, Dr. Kevin M. Yeager, for providing me with guidance and support throughout my time as a graduate student in the Department of Earth and Environmental Sciences at the University of Kentucky. The high standards that he set for myself and all of his graduate students have challenged me to expand my studies beyond previous research efforts in environmental geology and geochemistry, as well as my knowledge in studies outside of geology. These high expectations have prepared me for my professional future as a scientist. I would also like to thank the other two members of my research committee, Dr. Christopher Barton and Dr. Andrea Erhardt for their guidance and support during my research.

Thank you to Dr. Jordan Munizzi at the Kentucky Stable Isotope Geochemistry Laboratory (KSIGL). I truly appreciate all of his help in analyzing particulate organic carbon and stable isotopes. In addition, I thank the Office of Surface Mining, Reclamation and Enforcement (OSMRE) for their financial support from the Applied Science Program, via a grant entitled, "Evaluating the Influence of the Forestry Reclamation Approach on Water Quality and Hydrology on Appalachian Coal Mines”. This study would not have been possible without the financial support provided by OSMRE.

Next, I want to thank my family. My loving wife Christina Bond and my mother Betty Bond have stood by me and supported me in every way possible as I furthered my studies. My father Eddie Bond, who passed away in 2018, was a source of inspiration and 
guidance, and always supported my pursuit to further myself as a scientist. I know that without him I would not have been able to achieve what I have.

Finally, I want to thank my fellow lab workers and graduate student at the Sedimentary Environmental and Radiochemical Research Laboratory $\left(\mathrm{SER}_{2} \mathrm{~L}\right)$ for their help: Becky Smiley, Spencer Dixon, Jude Odomon, Daulton Hanes, Gabriella Evans, and Kimberly Schindler. Without the continued support of all mentioned I would not have been able to succeed while studying at the University of Kentucky. From the bottom of my heart, I want to thank you for everything you have done to help me. 


\section{TABLE OF CONTENTS}

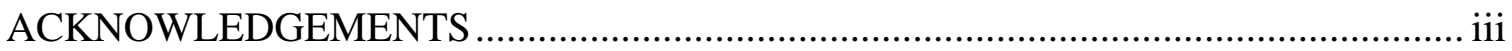

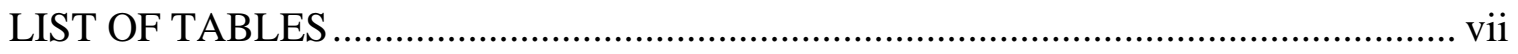

LIST OF FIGURES ...................................................................................... viii

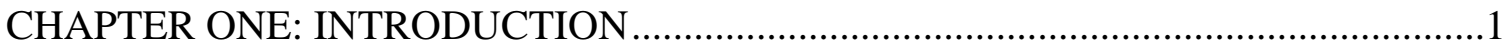

1.1 History and Impacts of Mining and Logging in Eastern Kentucky .........................1

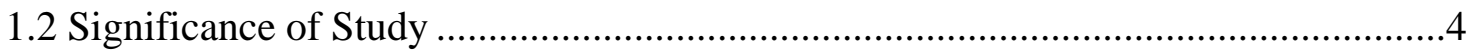

1.2.1 Surface Mining Control and Reclamation Act (SMCRA) .............................. 5

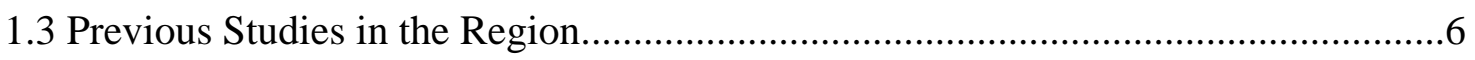

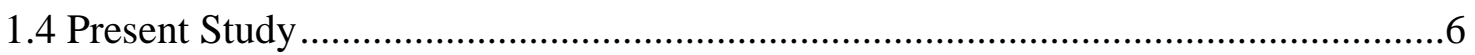

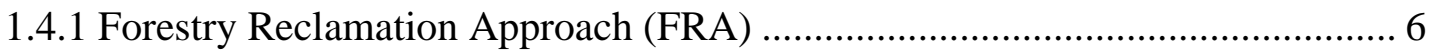

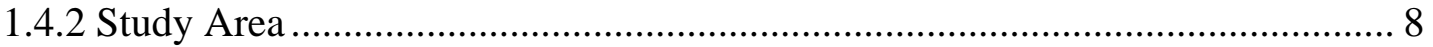

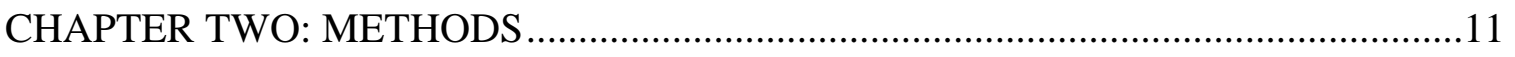

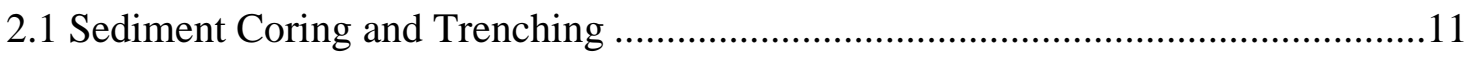

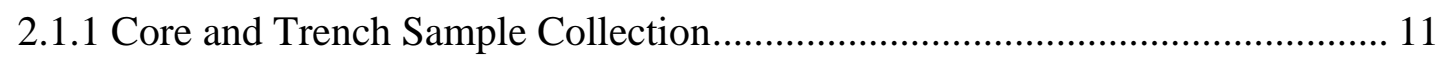

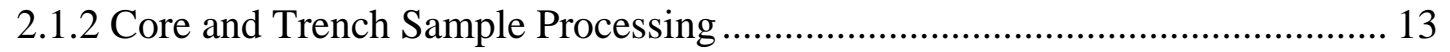

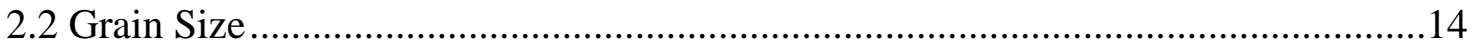

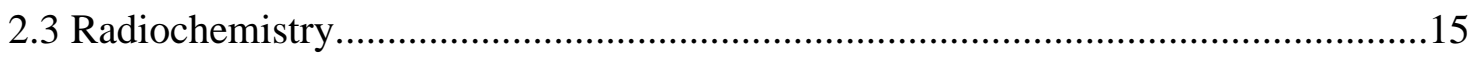

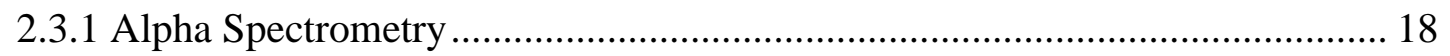

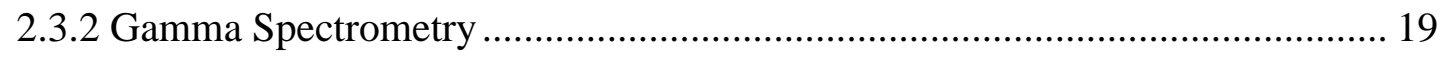

2.4 Particulate Organic Carbon and Stable Carbon Isotopes .....................................20

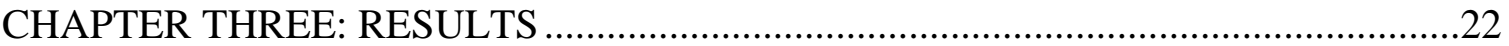

3.1 Reclaimed Mine Land Digital Elevation Models (DEM) ................................ 22

3.2 Robinson Forest Satellite Imagery and Sub-Basins ..................................... 24

3.3 Bent Mountain Satellite Imagery and Sub-Basins.......................................... 29

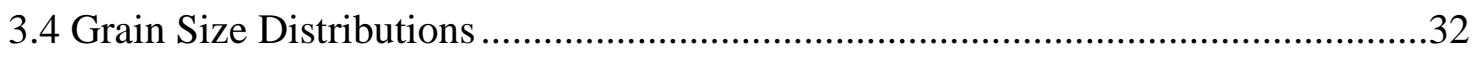

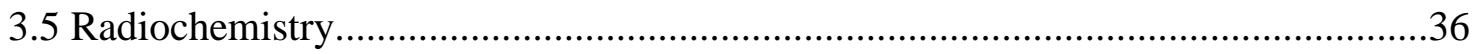

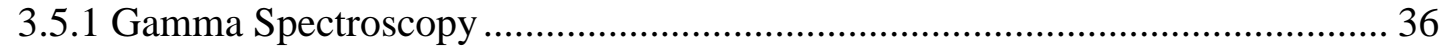

3.5.2 Alpha Spectroscopy and Sediment Accumulation Rates .............................. 43

3.6 Particulate Organic Carbon and Stable Isotopes ...............................................52

3.6.1 Particulate organic carbon and bulk density ............................................... 52

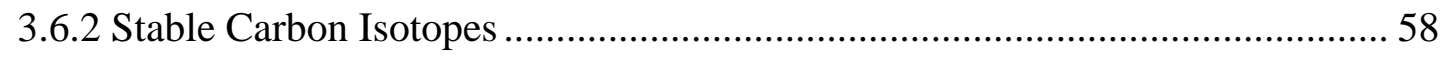




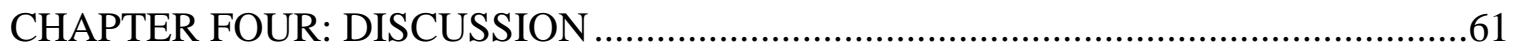

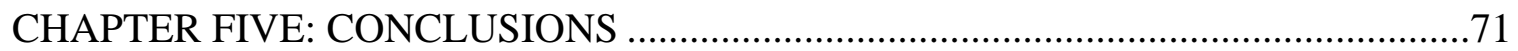

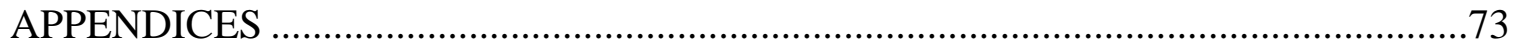

Appendix A. Study Site Coordinates, Core Shortening, Calculated Mining Activity,

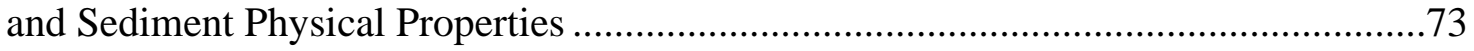

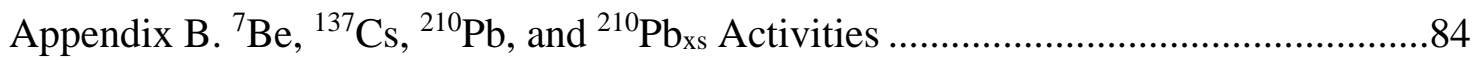

Appendix C. Stable Isotope and POC Values .......................................................93

Appendix D. Sediment Accumulation Rates.......................................................102

Appendix E. Full Core and Trench Profiles .......................................................106

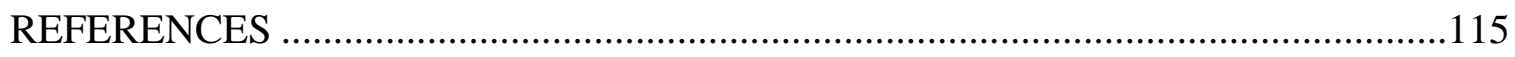

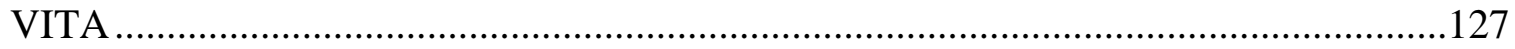




\section{LIST OF TABLES}

Table 1. Study sites summary, including types of disturbances, when reclamation occurred, reclamation methods, and when sites were sampled. 10

Table 2. ${ }^{137} \mathrm{Cs}$ and ${ }^{7} \mathrm{Be}$ inventories for all trenches and cores. ${ }^{*}$ Indicates incomplete ${ }^{137} \mathrm{Cs}$

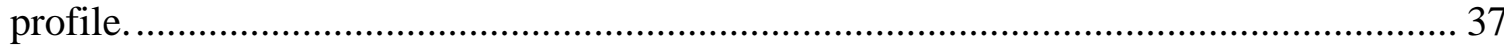

Table 3. LARs and MARs from 1952 and 1963 for sites with ${ }^{137} \mathrm{Cs}$ data...................... 38

Table 4. ${ }^{210} \mathrm{~Pb}_{\text {ex }}$ inventories for all cores compared against inventories expected from atmospheric deposition alone, and sedimentation ratios. 45

Table 5. Comparison of average ${ }^{210} \mathrm{~Pb}_{\mathrm{xs}}$ MARs and LARs for all sites. All uncertainties

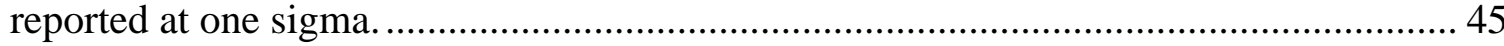
Table 6. POC inventories $(1-10 \mathrm{~cm})$, and surface $(0-2 \mathrm{~cm}$ for trenches; and mean value of 1-2 cm for push cores) POC fluxes for all cores and trenches. POC fluxes are calculated using mean ${ }^{210} \mathrm{~Pb}$ ex-derived sediment accumulation rates. 


\section{LIST OF FIGURES}

Figure 1. Locations of all mined (red) and logged (green) study sites. The top map shows site locations within the Johns Creek and Troublesome Creek drainage basins, and the Kentucky counties within which each are located. The bottom map shows 2016 satellite imagery (ArcGIS 10.5) for all sites............................................................................... 9 Figure 2. Typical sediment profile of reclaimed mine land with core extraction (top of core in red). Example sediment layers include fine-grained sands (A), silt/clays (B), silt/clays with larger erratic cobbles (C), and sand/silt with large cobbles (D) ................ 12 Figure 3. ${ }^{238} \mathrm{U}$ decay series (University of Wisconsin, wisc.edu).................................. 16 Figure 4. High resolution DEMs of reclaimed mine lands around study sites at Robinson Forest Guy Cove (top left - RFGC), Star Fire Mine (top right - SFMC), Bent Mountain Mine (lower left - BM), and Valley Fill Williams Branch (bottom right - VFWB). Valley fills near VFWB and RFGC are shown by white arrows. 23

Figure 5. High resolution DEMs of logged areas around study sites at Robinson Forest Millseat (top left - RFMS), Forestry control (top right - FCA), and Field branch (bottom left - RFFB).

Figure 6. Satellite imagery (2016) showing the locations of previously logged sites (red) and the sub-basins (blue) within which they are located. RFMS (top left) and RFFB (top right) are both located within the Clemons Fork sub-basin. FCA (bottom left) is located within the Coles Fork sub-basin. 25

Figure 7. Satellite imagery (2016) showing RFGC (red) and its location within the Laurel Fork sub-basin (blue). Barren areas of the sub-basin (black) are shown for 1994, and 1998 26

Figure 8. Changes in mining activity for the Laurel Fork sub-basin from 1994-2016.... 27 Figure 9. Satellite imagery (2016) showing SFMC (red) and its location within the Long Fork sub-basin (blue). Barren areas of the sub-basin (black) are shown for 1994, 1998,

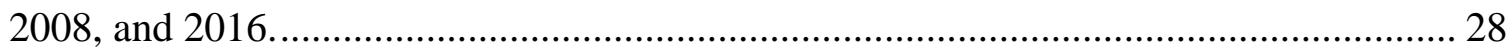

Figure 10. Changes in mining activity for the Long Fork sub basin from 1994-2016.... 29 Figure 11. Satellite imagery (2016) showing VFWB (red) and its location within the Troublesome Creek sub-basin (blue). Barren areas of the sub-basin (black) are shown for 1998, 2008, and 2016. 30

Figure 12. Changes in mining activity for the Troublesome Creek sub basin from 19942016.

Figure 13. Satellite imagery (2016) showing BM (red) and its location within the Brush Fork sub-basin (blue). Barren areas of the sub-basin (black) are shown for 1994, 1998, 2008, and 2016...... 31

Figure 14. Changes in mining activity for the Brush Fork sub-basin from 1994-2016.... 32 Figure 15. Grain size distributions vs. depth for control site trenches RFMS_17T (left) and FCA_15 (right). 
Figure 16. Grain size distributions vs. depth for trenches RFGC_17T (left) and

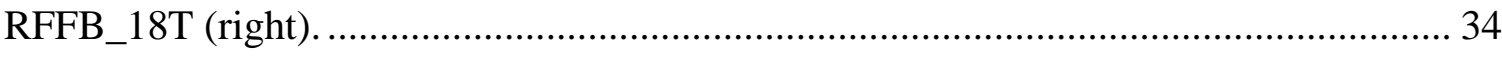

Figure 17. Grain size distributions vs. depth for push cores RFGC_17PC_A (left) and

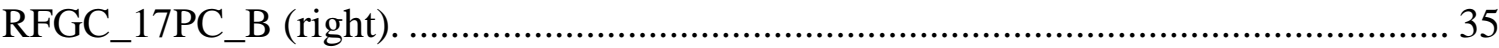
Figure 18. Grain size distributions vs. depth for trenches SFMC_15 (left) and BM_07_16

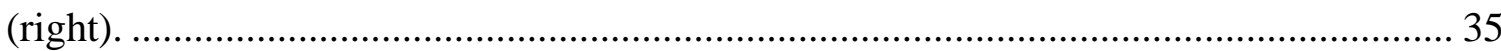

Figure 19. Grain size distribution vs. depth for push core VFWB_17PC_A. .................. 36 Figure $20 .{ }^{7} \mathrm{Be}$ (left) and ${ }^{137} \mathrm{Cs}$ (right) activity concentration profiles for trench RFMS_17T. The dashed line denotes the year 1952 ..................................................... 39 Figure $21 .{ }^{7} \mathrm{Be}$ (left) and ${ }^{137} \mathrm{Cs}$ (right) activity concentration profiles for trench FCA_15.

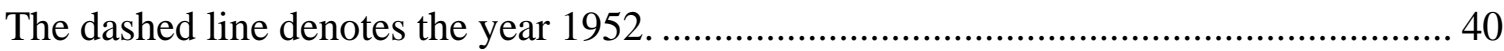
Figure 22. ${ }^{7} \mathrm{Be}$ (left) and ${ }^{137} \mathrm{Cs}$ (right) activity profiles for trench RFGC_17T. ............... 41 Figure 23. ${ }^{137} \mathrm{Cs}$ activity concentration profiles for push cores RFGC_17PC_A (left) and RFGC_17PC_B (right). The dashed and solid lines denote the years 1952, and 1963,

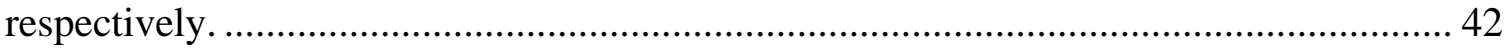

Figure $24 .{ }^{7} \mathrm{Be}$ activity profile for trench SFMC_15.................................................. 42

Figure $25 .{ }^{137} \mathrm{Cs}$-based sediment accumulation rates based on the 1952 (top) and 1963 (bottom) time markers for RFMS, FCA, and RFGC. Values for RFGC are based on mean values for the two push cores taken at the site. Uncertainties reported at one standard deviation. 44

Figure 26. Sediment mass accumulation rates (left) and linear accumulation rates (right)

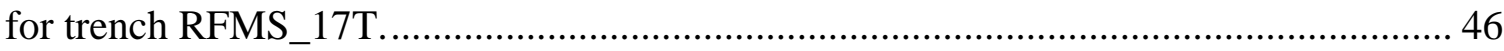

Figure 27. Sediment mass accumulation rates for trench FCA_15. Exponential regression is shown for data spanning 60 years BP to the present.

Figure 28. Sediment mass accumulation rates (left) and linear accumulation rates (right) for trench RFGC_17T. Shaded sections provide the timing of grassland reclamation (red) and the FRA (blue)

Figure 29. Sediment mass accumulation rates (left) and linear accumulation rates (right) for push core RFGC_17PC_A. Shaded sections provide the timing of grassland reclamation (red) and the FRA (blue).

Figure 30. Sediment mass accumulation rates (left) and linear accumulation rates (right) for push core RFGC_17PC_B. Shaded sections provide the timing of grassland reclamation (red) and the FRA (blue). Exponential regression fits for 40 years BP to present are shown (left, both plots), as are fits from 40 to 100 years BP (right, both plots).

Figure 31. Sediment mass accumulation rate for trench SFMC_15. The shaded section of the graph provides the timing of the FRA (blue) ............................................................. 51 Figure 32. ${ }^{210} \mathrm{~Pb}$ ex MARs and LARs for study sites. Uncertainties reported at one standard

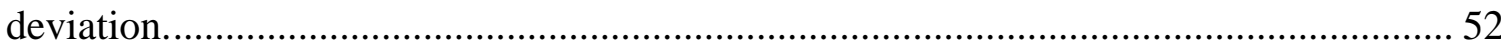
Figure 33. POC inventory $(1-10 \mathrm{~cm}$ ) (top), and POC flux (bottom) for all study sites.... 53 Figure 34. Comparison of ${ }^{210} \mathrm{~Pb}_{\mathrm{ex}}$ mass accumulation rates and $\mathrm{POC}$ inventories for all

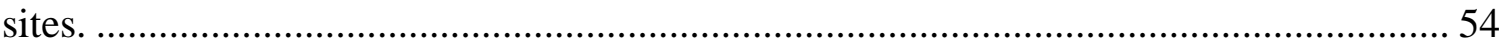


Figure 35. Particulate organic carbon (POC) concentration profiles for trenches RFMS_17T (left) and FCA_15 (right).

Figure 36. Particulate organic carbon (POC) concentration profiles for trenches

RFFB_18T (left) and RFGC_17T (right). 55

Figure 37. Particulate organic carbon (POC) concentration profiles for push core RFGC_17PC_A (left) and RFGC_17PC_B (right). 56

Figure 38. Particulate organic carbon (POC) concentration profiles for trenches SFMC_15 (left) and BM_07_16 (right). 57

Figure 39. Particulate organic carbon (POC) concentration profile for push core VFWB_17PC_A. 57

Figure $40 . \delta^{13} \mathrm{C}$ profiles for trenches RFMS_17T (left) and FCA_15 (right). 58

Figure $41 . \delta^{13} \mathrm{C}$ profiles for trench RFGC_17T (left) and push core VFWB_17PC_A (right). 59 Figure $42 . \delta^{13} \mathrm{C}$ profiles for push cores RFGC_17PC_A (left) and RFGC_17PC_B (right). 60

Figure 43. $\delta^{13} \mathrm{C}$ profiles for trenches SFMC_15 (left) and BM_07_16 (right)................. 60 


\section{CHAPTER ONE: INTRODUCTION}

\subsection{History and Impacts of Mining and Logging in Eastern Kentucky}

Since the arrival of Europeans, coal mining and timber production have continually spread throughout Appalachia. Coal was discovered in Kentucky in 1750, and by 1774, the first European settlement was established (Harrison and Klotter 2009). This also led to the increased need for timber production to construct housing and provide fuel for heating and cooking.

The first commercial coal mine was established in Kentucky in 1820, and from that time until 1970 coal mining was a major source of economic prosperity throughout Appalachia (Goldberg and Power 1972). In 1970, coal production saw a large increase that lead to a major economic boom that lasted until the mid-1980's (Black et al. 2005a). From 1969 to 1974 the price of coal increased by roughly 44\%. Coal production continued to increase until 1977, at which point prices stabilized until 1982. After this time, the price of coal drastically decreased until the late 1980's (Black et al. 2005b). With the growing availability of more efficient energy sources (including natural gas), declining Appalachian coal reserves (Milici 2000), and increasing awareness of the environmental impacts of mining, coal mining is today no longer a major economic force in Appalachia.

In 1990, the Clean Air Act of 1963 (Public Law 88-206) was amended to address air pollution and acid rain (Public Law 101-549). The coal found throughout Kentucky contains a relatively high concentration of sulfur, which contributes to acid rain (Huffman et al. 1991; Eble and Hower 1997). Natural gas was discovered in Kentucky in 1818 , and its recovery and use has continued to increase over time with roughly 4,000 
operating gas wells present by the mid-20 $0^{\text {th }}$ century (Hunter and Young 1953). By 1999, $\sim 84 \%$ of the natural gas produced in the U.S. originated from the Antrim Shale (Michigan basin) and Ohio Shale (Appalachian basin) since then, other basins throughout the country have increased production (Curtis 2002).

Unfortunately, coal mining in its various forms has led to many detrimental impacts on the environment, some of which persist for years, decades, or much longer after mining activities have decreased or ceased entirely. Coal mining affects plant and animal life, soils, sediments, water quality, and the atmosphere. The effects on plant life are seen in areas where mountain top removal mining practices and accompanying valley fills have led to decreased botanical biodiversity in the region (e.g., Meier et al. 1995; Schuler and Gillespie 2000; Wyatt and Silman 2010; Sheoran et al. 2010; Ussiri and Lal 2005). This decrease in plant diversity not only reduces viable habitats for wildlife, but also decreases future timber production prospects due to the loss of commercially important native hardwood trees. Mining has also been shown to increase sediment loading in adjacent streams during storm flow events (e.g., Bonta 2007; Mangena and Brent 2006). A study from the late 1960s showed that wildlife was heavily impacted by the disturbance of over 800,000 acres of land, resulting in 5,000 miles of streams and some 13,800 acres of impoundments being contaminated by both sediment and acid mine water due to mining in Appalachia (Boccardy and Spaulding 1968).

From 1992 to 2006, areas throughout Appalachia with the highest mining activity were shown to have lost up to $7.6 \%$ of the total forest in the area, but the loss of interior forests ranged from 7-20\% (Wickham et al. 2007). The loss of interior forests is as significant as the loss of total forests because it leads to habitat fragmentation for native 
wildlife. The loss of interior forests was up to $5 \%$ greater than the loss of total forested land where strip mining occurred (Wickham et al. 2013). Mining activities affect both soils and sediments, primarily by erosion, including the loss of topsoil from mining activity (Holl and Cairns 1994; Kozlowski 1999). Topsoil loss from mining inhibits the regrowth of native hardwood tree species, in part due to losses of organic material and seeds (Bradshaw and Chadwick 1980).

Runoff from mined areas often shows decreases in water quality, which can be further degraded by valley fills, in part by the burial and/or capture of headwater streams (e.g., Ryan and Meiman 1996; Palmer et al. 2010). Adverse, generally local effects from mining on water quality include: increases in electrical conductivity (EC), increased dissolved concentrations of sulfate and various heavy metals, organic matter (OM) enrichment, increased turbidity, lower invertebrate density, and decreased plant diversity (e.g., Bernhardt et al. 2012; Fritz et al. 2010; Price and Wright 2016; Swer and Singh 2004).

Extensive logging occurred within the Robinson Forest of eastern Kentucky from 1908 to 1923 (Kalisz and Dotson 1989). During this period, logs were transported to mills by floating them down river or by railroad. Logging can significantly affect soil erosion, stream flow, and surface water quality (Arthur et al. 2007; Hatten et al. 2018), as well as forest management (Foil and Ralston 1967; Shaw et al. 1987). Deforestation has been shown to cause large changes in microbial communities in sandy soils (Crowther et al. 2014). Regions that have been previously logged have shown a decline in soil nutrient availability due to the removal of OM (Brais et al. 1995; Hamlett et al. 1990; Huang et al. 
1996). Due to the demand for greater timber production, mechanized logging operations are still prevalent within Appalachian hardwood forests (Wang et al. 2005).

Modern logging operations can adversely affect soils by increasing compaction and decreasing water content (Reisinger et al. 1988). Increased soil compaction and disturbances on steep slopes can lead to higher rates of erosion, which subsequently drive higher sediment fluxes to nearby streams and increased sedimentation (Martin 1988; Martin and Hornbeck 1994). Areas around streams can potentially be affected the most by increased compaction due to a reduction in water content from increased bulk density and reduced macropore spacing (Moehring and Rawls 1970; Greacen and Sands 1980).

\subsection{Significance of Study}

This study is significant to this region due to the loss of forestlands and their degradation due to longstanding and spatially extensive mining and logging activities. These disturbances have drastically altered regions of eastern Kentucky from their natural state. This can lead to damaged topsoil, or topsoil that has been removed entirely, especially in areas that have been previously mined (Mensah 2015). This study can aid in comparing the effect of different reclamation techniques on sediment accumulation rates in reclaimed mine lands. Erosion from logging activity can occur from the construction and use of roads and the loss of sediment from tree roots (McCashion and Rice 1983; Kochenderfer 1970). Logging operations have been shown to increase sediment yields 100-fold in affected watersheds (O'Loughlin et al. 1980, 1982; O'Loughlin and Pearce 1976). Areas that have been previously strip-mined show adverse changes in sediment transport (i.e., high sedimentation of streams) due to elevated stream bank erosion (Fox 2009). In general, areas disturbed by current strip-mining operations show elevated 
sediment loads within their respective watersheds (Wood and Armitage 1997). Reclaimed mines show an initial increase in sediment loading due to reclamation disturbances, followed by a drastic decrease in sediment loading (Bonta 2000). Efforts to stabilize stream banks and reduce sediment loading in affected streams, due to mining and logging disturbances, could be aided by this study.

\subsubsection{Surface Mining Control and Reclamation Act (SMCRA)}

The Surface Mining Control and Reclamation Act (SMCRA) (Public Law 95-87 Federal Register, 445-532) was introduced in 1977 by Morris K. Udall to mitigate the detrimental effects of strip mining on land stability, erosion, and sedimentation. Grassland reclamation is the primary technique used post SMCRA (e.g., Burger 2011; Zipper et al. 2011). Grassland reclamation falls under SMCRA, but has led to higher rates of soil compaction and the proliferation of widespread ground covers that slow the natural encroachment of forests (e.g., Angel et al. 2009; Groninger et al. 2007). The groundcover vegetation commonly used in grassland reclamation are often low diversity and exotic cool season grasses and forbs, that tend to form denser biomass cover, are shallow rooted, and aggressive (e.g., Cavender et al. 2014; Bauman et al. 2015; Swab et al. 2017).

This use of groundcover commonly decreases water infiltration (Clark and Zipper 2016; Bohrer et al. 2017) and prevents the establishment of plant species with deep root systems that can reduce soil compaction (Angel et al. 2006; Martin 2006). Soil compaction has the potential to decrease the available nutrients and water that plants can uptake, depending on the soil grain sizes present (Arvidsson 1999). The severity of soil compaction can be heavily influenced by the grain size of soil (Hamza and Anderson 
2005; Gomez et al. 2002). Coarse-grained materials (i.e., sands, gravels) are less compactable, while fine-grained materials (i.e., silts, clays) are highly susceptible to compaction (Schuler et al. 1986). Reclaimed mine lands with high soil compaction have also been shown to experience increased frequency of flooding events, due to reduced water infiltration (e.g., Phillips 2004; Ferrari et al. 2009).

\subsection{Previous Studies in the Region}

Previous studies in this region have focused heavily on the restoration of reclaimed mine lands by utilizing different reclamation techniques. The grassland reclamation approach emphasizes the use of aggressive ground cover species while maintaining low grazing pressure from livestock. This method is commonly used in mid-western strip mines to mitigate the cost of reclamation and stabilize the ecosystem (Ussiri et al. 2006). The grassland reclamation approach can take decades to centuries or much longer before natural reforestation returns these areas to pre-mining conditions (e.g., Holl 2002; Angel et al. 2009; Lima et al. 2016). A study conducted in 2008 compared a mine reclaimed 15 years prior using grassland reclamation to an unmined watershed, and showed that annual runoff volumes were similar in both watersheds. However, the reclaimed mining site showed higher volumes of runoff during storm flow events due to high soil bulk density and reduced infiltration rates (Simmons et al. 2008). A 2015 study conducted in West Virginia showed that mined watersheds exhibited an increase in silt and sand deposition compared to unmined watersheds (Jaeger 2015).

\subsection{Present Study}

\subsubsection{Forestry Reclamation Approach (FRA)}

This study focused on the Forestry Reclamation Approach (FRA), and grassland 
reclamation, and their impacts on sediment accumulation rates. The FRA uses a five-step approach to reforest mined lands and decrease overall recovery time for forest establishment. The first step is the creation of suitable topsoil (4 ft.) to allow for the best achievable conditions for tree seedling survival using weathered sandstones and existing topsoil. In the second step, topsoil is loosely graded to limit soil compaction. This is done by dumping and leveling soil in separate operations using the lightest available equipment. The third step uses indigenous ground cover species that facilitate tree growth such as foxtail millet (Setaria italica), red top (Agrotis palustris), perennial ryegrass (Lolium perenne), rye (Secale cereal), orchardgrass (Dactylis glomerate), birdsfoot trefoil (Lotus corniculatus), and Ladino clover (Trifolium repens). The fourth step is the planting of two native tree species; one chosen to provide wildlife forage and to promote soil stability, and the second selected primarily as a commercial crop. Species used to promote wildlife forage and soil stability include redbud (Cercis canadensis), hawthorn (Crataegus mollis), dogwood (Cornus florida), and black locust (Robinia pseudoacacia) (Burger and Zipper 2002). Commonly utilized commercial hardwood species include red oak (Quercus rubra), white oak (Quercus alba), green ash (Fraxinus pennsylvanica), black cherry (Prunus serotina), sugar maple (Acer saccharum), and yellow-poplar (Liriodendron tulipifera). The final step is to use proper planting techniques to reduce the loss of new saplings (Adams 2017; Angel et al. 2009), including proper storage of seedlings to prevent drying out, planting during the late winter and early spring to ensure adequate soil moisture and higher soil temperature, and planting to a proper depth. Use of the FRA method has been shown to increase the number of surviving seedlings of native hardwood tree species (Groninger et al. 2007). This method is superior to grassland 
reclamation because of its potential to minimize soil compaction while reestablishing native forests.

\subsubsection{Study Area}

This study is mainly focused on four separate reclaimed coal mines (mountain top removal), and three previously logged sites, for a total of seven research sites. The sites include (1) Robinson Forest Mill Seat (RFMS_17T), (2) Robinson Forest Guy Cove (RFGC_17T, RFGC_17PC_A, RFGC_17PC_B), (3) Valley Fill Williams Branch (VFWB_17PC_A), (4) Robinson Forest Field Branch (RFFB_18T), (5) Star-Fire mines (SFMC_15), (6) Bent Mountain mines (BM_07), and (7) Robinson Forest Control site (FCA_15). The Bent Mountain mines are located within the Johns Creek drainage basin that covers an area of $581 \mathrm{~km}^{2}$. All other research sites are found within the Troublesome Creek drainage basin, which encompasses an area of $637 \mathrm{~km}^{2}$ (Figure 1). Sites RFGC, VFWB, SFMC, and BM_07 were previously mined. Sites RFMS, RFFB, and FCA were previously logged (Table 1). Mill Seat, Guy Cove, Field Branch, and Williams Branch were sampled within riparian areas. Robinson Forest control was sampled from a ridgetop, while Star Fire and Bent Mountain were sampled from upland areas. 

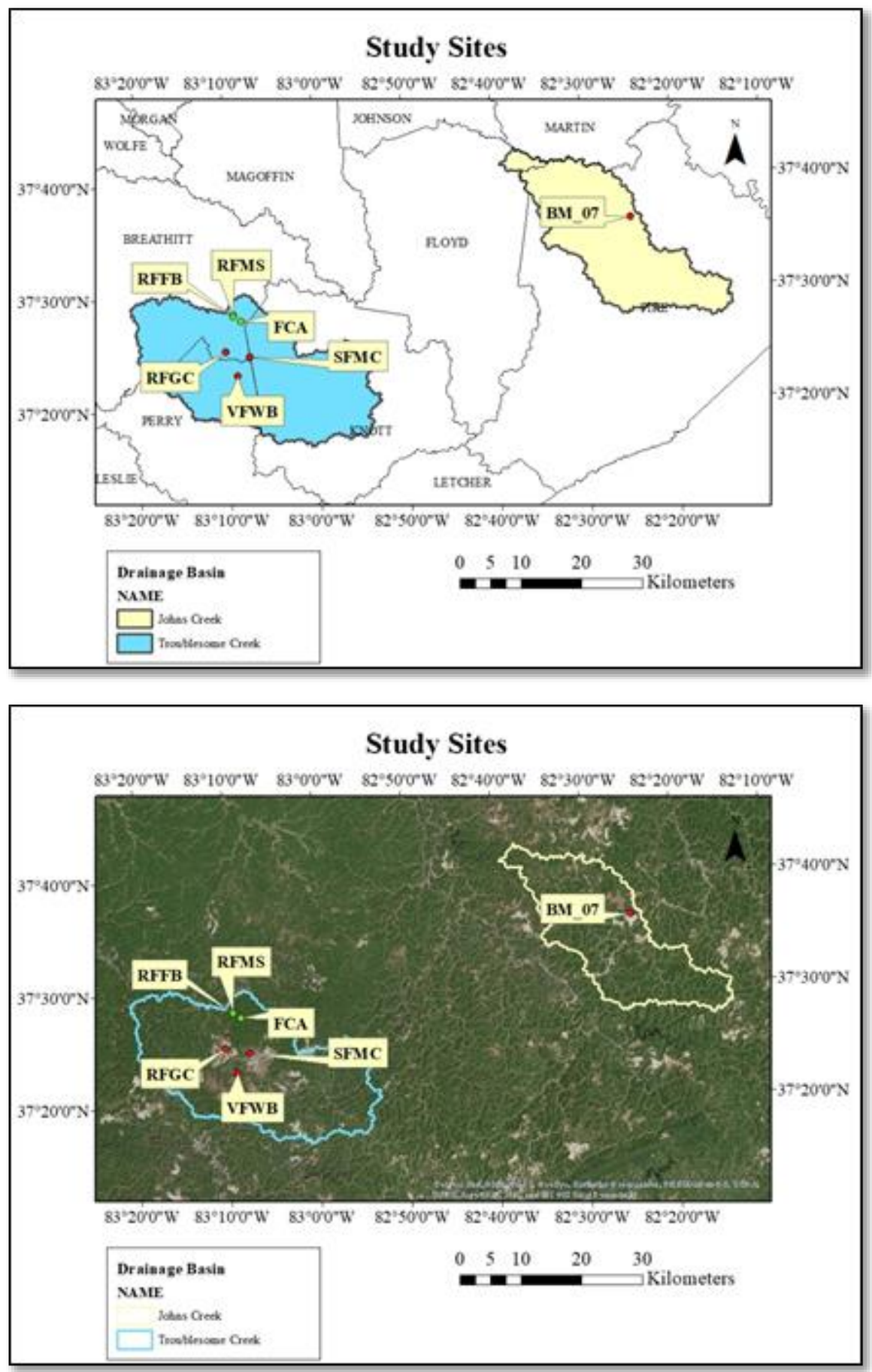

Figure 1. Locations of all mined (red) and logged (green) study sites. The top map shows site locations within the Johns Creek and Troublesome Creek drainage basins, and the Kentucky counties within which each are located. The bottom map shows 2016 satellite imagery (ArcGIS 10.5) for all sites. 
Table 1. Study sites summary, including types of disturbances, when reclamation occurred, reclamation methods, and when sites were sampled.

\begin{tabular}{|c|c|c|c|c|}
\hline \multirow{2}{*}{ Site } & Disturbance & $\begin{array}{c}\text { Year } \\
\text { regenerated or } \\
\text { reclaimed }\end{array}$ & Method & $\begin{array}{c}\text { Year } \\
\text { Sampled }\end{array}$ \\
\hline RFMS & Logged & 1923 & Natural Regeneration & 2017 \\
\hline FCA & Logged & 1925 & Natural Regeneration & 2015 \\
\hline RFFB & Logged & 1982 & Natural Regeneration & 2018 \\
\hline RFGC & Mined & 1997 and 2007 & Pasture and FRA & 2017 \\
\hline VFWB & Mined & 2012 & Pasture & 2017 \\
\hline BM_07 & Mined & 2004 & FRA & 2016 \\
\hline SFMC & Mined & 1997 & FRA & 2015 \\
\hline
\end{tabular}

The RFMS site was logged until 1923 ( 94 years prior to sampling) and naturally regenerated from seed and stump sprouts (Gough 2013). The FCA site was logged until 1925 (90 years prior to sampling), and then naturally regenerated. The RFFB site was logged up to 1982 (36 years before sampling), and then naturally regenerated. The RFGC site was mined and initially reclaimed as pasture 20 years ago (1997), and was subsequently disturbed and restored using the FRA in 2007. The VFWB site was mined and reclaimed as pasture five years before sampling (2012). The SFMC and BM sites were both mined, and both then reclaimed using the FRA 18 (1997), and 12 years (2004) prior to sampling, respectively. SFMC was constructed using mine spoil to a depth up to 6 feet.

The RFMS, FCA, and RFFB sites have histories of logging and natural regeneration, whereas the RFGC, SFMC, BM, and VFWB sites were mined using mountain top removal that led to valley fills (Bernhardt and Palmer 2011). While valley fills contribute to the loss of habitat for terrestrial species (elk, deer, black bears), they are also known to lower the diversity of benthic organisms in streams (Pond et al. 2014). 
These valley-fill areas can bury, capture, or decrease the flow of headwater streams, thus negatively impacting stream and forest ecology downstream over considerable distances (up to 300 km) (e.g., Price et al. 2016; Fritz et al. 2010; Tiwary 2001).

This study hypothesizes that the FRA will result in larger magnitude sediment accumulation rates in reclaimed mine lands as compared to those reclaimed using grassland reclamation. The analytical approaches used for this study are:

1. Sites mapped with ArcGIS software for high resolution DEMs with satellite imagery to track changes in land affected by mining activity

2. Grain size analysis

3. Radiochemical analysis

4. Particulate organic carbon (POC) analysis

5. Stable isotope $\left(\delta^{13} \mathrm{C}\right)$ analysis of sedimentary $\mathrm{OM}$

\section{CHAPTER TWO: METHODS}

2.1 Sediment Coring and Trenching

\subsubsection{Core and Trench Sample Collection}

At each site, sediment cores and trench samples were collected where possible. A total of six trenches were sampled for all of the study sites. Trenches were excavated with a shovel to a depth of $50 \mathrm{~cm}$, or until the water table was reached, and sampled at $2 \mathrm{~cm}$ intervals using two-meter sticks braced against the side of the trench wall. All samples were bagged and held in cold storage until processing began. Sediment cores (Figure 2) 
were collected from each of the sites if possible, for a total of three cores, utilizing aluminum core sleeves (4 in. diameter).

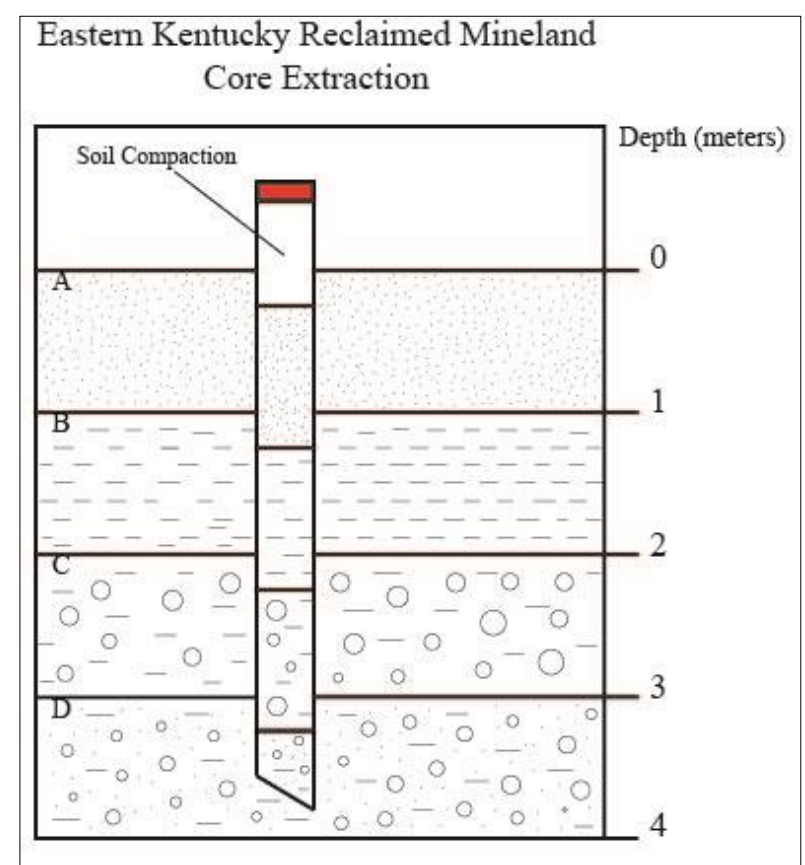

Figure 2. Typical sediment profile of reclaimed mine land with core extraction (top of core in red). Example sediment layers include fine-grained sands (A), silt/clays (B), silt/clays with larger erratic cobbles (C), and sand/silt with large cobbles (D).

Aluminum core sleeves were used due to the common presence of large clastic materials; reclaimed mine land soils can contain up to $80 \%$ rock fragments derived from bedrock exposed by mining (e.g., Haering et al. 2004; Jaeger 2015). Core sampling depths ranged up to $\sim 1 \mathrm{~m}$ with the intention of recovering sediment representing pre- and post-disturbance (mining or logging) periods for analysis and comparison. Each casing was physically driven into the sediment, and headspace was measured for each core prior to extraction to account for soil compaction during sampling (core shortening). Sediment accumulation rates are expressed in terms of mass accumulation rates to account for core shortening. All cores were sealed after extraction to minimize the risk of sediment 
mixing. Finally, cores and trench materials were transported to and stored at the Sedimentary and Environmental Radiochemistry Research Laboratory $\left(\mathrm{SER}_{2} \mathrm{~L}\right)$, Department of Earth and Environmental Sciences, at the University of Kentucky in preparation for physical, geochemical, and radiochemical analyses.

\subsubsection{Core and Trench Sample Processing}

Core casings were cut longitudinally using a rotary saw, with care taken to minimize disturbance of the sediment inside. After the casings were cut, medium gauge piano wire was used to cut through the sediments inside, allowing the core to be split open longitudinally. All cores were then photographed at a fixed distance of $1 \mathrm{~m}$ directly above, and described noting changes in grain size, textures, facies and color based on comparison to the USGS Munsell soil color chart.

All cores were sectioned at uniform intervals to provide sediment aliquots for various analyses. The first step was the collection of bulk density plugs for RFMS, RFGC, VFWB, and RFFB. Bulk density was not measured for SFMC, BM_07, and FCA. Bulk density was calculated using:

$$
B d=\frac{M_{s}}{V_{t}}
$$

where $\mathrm{M}_{\mathrm{s}}$ is the mass of dried soil, and $\mathrm{V}_{\mathrm{t}}$ is the total volume. Each plug was collected at $2 \mathrm{~cm}$ intervals spanning the full length of each core. The bulk density data allow sediment accumulation rates to be presented as linear accumulation rates. Each plug was placed into a pre-weighed $40 \mathrm{ml}$ aluminum tin, weighed, and dried at $70^{\circ} \mathrm{C}$ for 24 hours (or longer as needed). All sample were then re-weighed and archived.

The first $50 \mathrm{~cm}$ of each core was divided into $1 \mathrm{~cm}$ sections, and the remainder was sectioned at $2 \mathrm{~cm}$ intervals. All samples were placed into pre-weighed $250 \mathrm{ml}$ aluminum 
tins, weighed and dried at $70^{\circ} \mathrm{C}$. After 48 hours, dried samples were re-weighed. All samples were then wet sieved (as needed) to remove macro OM and coarse clastic materials (larger than $500 \mu \mathrm{m}$ ), which was dried and weighed.

Trenches were excavated using shovels until bedrock or the water table was reached. Meter sticks were used to sample trench walls at $2 \mathrm{~cm}$ intervals, with samples removed using a hand spade and then bagged on site for transport. All core and trench samples were separated into aliquots for physical, radiochemical, and stable carbon isotope analyses. All radiochemical aliquots were homogenized using a Retsch RM200 mortar grinder.

\subsection{Grain Size}

Grain size analysis was utilized to assess changes in sedimentary environments over the period of record for each set of samples (cores, trenches), and between sites. Changes in particle size can reflect changes in transport energy and deposition (Robinson and Slingerland 1998; Koestner et al. 2011). Sample aliquots for grain size were weighed at 5-10 g and placed into $250 \mathrm{ml}$ clear Pyrex beakers. Samples were then treated with $10 \mathrm{ml}$ each of sodium hexametaphosphate, acetone, de-ionized water, and concentrated hydrogen peroxide $\left(\mathrm{H}_{2} \mathrm{O}_{2}\right)$. Micro organic material was oxidized using $\mathrm{H}_{2} \mathrm{O}_{2}$, preventing it from acting as a binding agent that can potentially skew mineral grain size data (Hillier 2001; Yeager et al. 2005). Sodium hexametaphosphate is a common dispersion agent that increases the surface area of the sample to facilitate OM oxidation by $\mathrm{H}_{2} \mathrm{O}_{2}$ (Plouffe et al. 2001). Samples were treated with $\mathrm{H}_{2} \mathrm{O}_{2}$ at room temperature for $\sim 24$ hours, and then heated at $100^{\circ} \mathrm{C}$ on hotplates while receiving 5-10 ml additions of $\mathrm{H}_{2} \mathrm{O}_{2}$ until obvious reactions ceased. 
After removal of micro organic material, samples were rinsed into $50 \mathrm{ml}$ centrifuge tubes and treated with magnesium chloride $(\mathrm{MgCl}$; if needed) to flocculate any fine suspended sediment. Each sample was then centrifuged using an Allegra 14-X centrifuge at 2,000 rpm, and treated with additional $\mathrm{MgCl}$ until the water in the sample was clear, and decanted. This process was repeated three times to remove excess $\mathrm{H}_{2} \mathrm{O}_{2}$. Samples were placed into pre-weighed tins, dried in an oven at $70^{\circ} \mathrm{C}$ for 24 hours, and sieved to remove particles larger than $2 \mathrm{~mm}$ in diameter. Material larger than $2 \mathrm{~mm}$ (gravel) was weighed and bagged separately to be included in the grain size determinations. Gravels were removed from samples due to particle size constraints of the Malvern Mastersizer. Once dried and re-weighed, samples were analyzed using a Malvern Mastersizer S2000 to obtain grain size measurements for particles ranging from 0.02 to $2,000 \mu \mathrm{m}$. Grain size data for each sample is presented as fractions of clay $(<4 \mu \mathrm{m})$, silt $(63-4 \mu \mathrm{m})$, and sand ( $2 \mathrm{~mm}-63 \mu \mathrm{m}$ ) according to the Wentworth scale (Wentworth, 1922).

\subsection{Radiochemistry}

Radionuclide data have been used to estimate short-term sediment mixing depths, to establish a time frame for sediment deposition, and to determine sediment accumulation rates at these sites, whenever possible (e.g., Al Hamarneh et al. 2003; Rice 1986). This was accomplished by analyzing samples to determine activity concentrations of the fallout radionuclides Cesium-137 $\left({ }^{137} \mathrm{Cs}\right)$, Lead-210 $\left({ }^{210} \mathrm{~Pb}\right)$, and Beryllium-7 $\left({ }^{7} \mathrm{Be}\right) .{ }^{7} \mathrm{Be}$, given its short half-life $\left(\mathrm{t}_{1 / 2}=53 \mathrm{~d}\right)$, was used to provide information on short-term $(\sim 1$ year) sediment mixing depths (Krishnaswami et al. 1980; Sharma et al. 1987).

The radionuclides ${ }^{137} \mathrm{Cs}$ and ${ }^{210} \mathrm{~Pb}$ were used to determine sediment accumulation rates (Baskaran 2011; Matisoff et al. 2002). ${ }^{137} \mathrm{Cs}$ has a half-life of 30.2 years (Ritchie 
and McHenry 1990). Large activity concentrations of ${ }^{137} \mathrm{Cs}$ appear in soils and sediments beginning in 1952, due to increases in the number and magnitudes of above-ground thermo-nuclear weapon tests, which reached their maxima in 1963 (e.g., Yeager et al. 2007; Ritchie and McHenry 1990). The largest activity concentration peaks typically represent 1963, due to the onset of the Partial Nuclear Test Ban Treaty in 1964. Sediment accumulation rates are calculated using ${ }^{137} \mathrm{Cs}$ here by:

$$
S=\frac{R_{p e a k}}{T}
$$

where $\mathrm{S}=$ sediment accumulation rate, $\mathrm{R}_{\text {peak }}=$ the depth (or cumulative mass depth) at which the ${ }^{137}$ Cs peak activity concentration appears, and $\mathrm{T}=$ time since 1963.

The radionuclide ${ }^{210} \mathrm{~Pb}$ has a half-life of 22.3 years and is part of the Uranium-238 decay series (Figure 3).

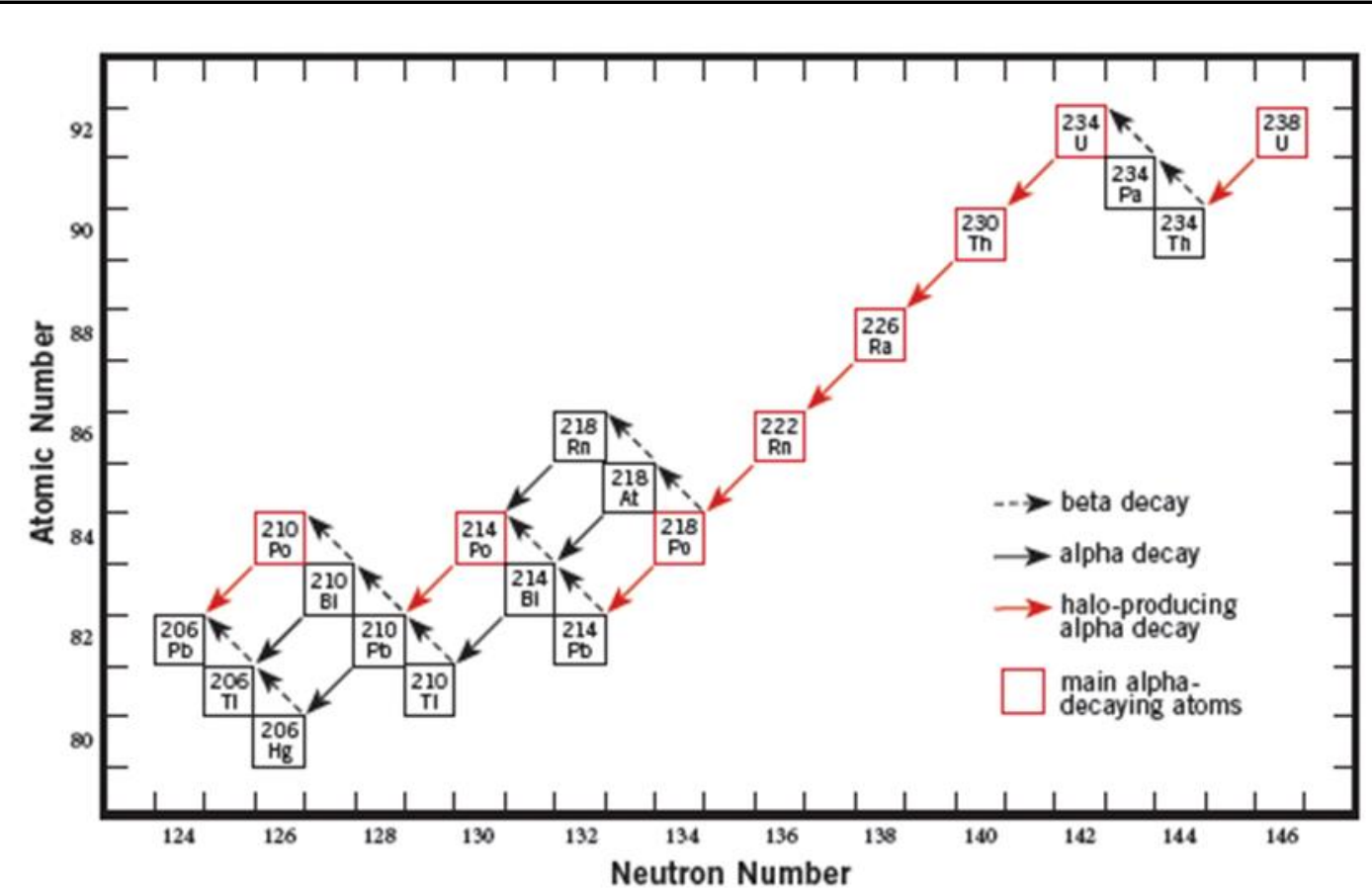

Figure $3 .{ }^{238} \mathrm{U}$ decay series (University of Wisconsin, wisc.edu). 
Excess ${ }^{210} \mathrm{~Pb}\left({ }^{210} \mathrm{~Pb}\right.$ ex $)$ is that fraction of total ${ }^{210} \mathrm{~Pb}$ delivered to soils through atmospheric fallout (principally bound to accumulating sediments), where it is combined with the supported fraction $\left({ }^{210} \mathrm{~Pb}\right.$ sup $)$ of total ${ }^{210} \mathrm{~Pb}\left({ }^{210} \mathrm{~Pb}_{\text {tot }}\right)$, which is produced by the in-situ decay of ${ }^{238} \mathrm{U}$ series isotopes in rocks, sediments, and soils (Walling et al. 2011; Benmansour et al. 2011). Supported ${ }^{210} \mathrm{~Pb}$ is determined using the mean value of the lowermost 3-5 samples at depth in the ${ }^{210} \mathrm{~Pb}$ tot profile. ${ }^{210} \mathrm{~Pb}$ ex is calculated using:

$$
{ }^{210} P b_{\text {ex }}={ }^{210} \mathrm{~Pb} \text { tot }-{ }^{210} \mathrm{~Pb} \text { sup }
$$

Sediment chronologies are calculated using the constant rate of supply model (Lubis 2013):

$$
t=\frac{1}{\lambda} \times \ln \left(A_{o} / A\right)
$$

where $\lambda=$ the decay constant of ${ }^{210} \mathrm{~Pb}\left(0.031 \mathrm{yr}^{-1}\right), \mathrm{A}_{\mathrm{o}}={ }^{210} \mathrm{~Pb}$ ex inventory of the entire sediment section, and $\mathrm{A}={ }^{210} \mathrm{~Pb}$ ex inventory below the sample being dated. Sediment mass accumulation rates are determined using the equation:

$$
S_{a}=\frac{\Delta m}{\Delta t}
$$

where $\Delta \mathrm{m}$ is the change in mass depth, and $\Delta \mathrm{t}$ is the change in time (Yeager et al. 2005, 2007). The three assumptions used for this model are: (1) ${ }^{210} \mathrm{~Pb}_{\text {ex }}$ is delivered to sediments at a constant rate through time, (2) the initial concentration of ${ }^{210} \mathrm{~Pb}$ in the sediment is variable, and (3) rates of sediment accumulation are variable. Sediment linear accumulation rates are calculated by dividing $S_{a}$ by the mean bulk density of the sediment section. 
The expected ${ }^{210} \mathrm{~Pb}_{\mathrm{ex}}$ inventory from atmospheric deposition alone $\left(537.42 \mathrm{mBq} \mathrm{cm}{ }^{-2}\right.$; Santschi et al. 1999; Baskaran et al. 1993) is used to compare against measured values at all sites to estimate net deposition or erosion over the last $\sim 100$ years. The expected ${ }^{210} \mathrm{~Pb}_{\mathrm{ex}}$ inventory was calculated by dividing the expected flux of ${ }^{210} \mathrm{~Pb}$ ex $\left(16.66 \mathrm{mBq} \mathrm{cm}{ }^{-2}\right.$ $\mathrm{yr}^{-1}$; Turekian et al. 1977) by the ${ }^{210} \mathrm{~Pb}$ decay constant $\left(0.031 \mathrm{yr}^{-1}\right)$. The expected ${ }^{137} \mathrm{Cs}$ inventory from atmospheric deposition alone has also been calculated $\left(135.20 \mathrm{mBq} \mathrm{cm}{ }^{-2}\right.$; Walling 1998; Larsen 1984). This was calculated using ${ }^{90} \mathrm{Sr}$ as a proxy for ${ }^{137} \mathrm{Cs}$ with the value decay corrected for 2016 using the equation:

$$
A_{t}=A_{0} \times e^{\lambda t}
$$

Where $A_{t}$ is the activity at $2016, A_{0}$ is the original activity, $\lambda$ is the decay constant for ${ }^{137} \mathrm{Cs}\left(0.023 \mathrm{yr}^{-1}\right)$ and $\mathrm{t}$ is the time elapsed (from 1983 to 2016 , see Larsen 1984).

Calculated radionuclide inventories can be compared to those expected from atmospheric deposition alone to assess if study sites are net depositional or erosional. All of the radionuclides considered here $\left({ }^{7} \mathrm{Be},{ }^{137} \mathrm{Cs},{ }^{210} \mathrm{~Pb}\right)$ readily adsorb onto fine-grained sediments at Earth's surface $\left({ }^{210} \mathrm{~Pb}\right.$ also adsorbs onto POC; e.g., Ab Razak et al. 1996; Wan et al. 2005; Vaaramaa et al. 2010) due to their low solubility and geochemistry (e.g., Baskaran 2011; Matisoff et al. 2002).

\subsubsection{Alpha Spectrometry}

Alpha spectrometry was used to determine activity concentrations of total ${ }^{210} \mathrm{~Pb}$ in samples. This was accomplished using acid digestion with concentrated hydrochloric $(\mathrm{HCl})$, nitric $\left(\mathrm{HNO}_{3}\right)$, and hydrofluoric acids $(\mathrm{HF})$. Sample material $(\sim 1 \mathrm{~g})$ was placed into pre-weighed Teflon beakers and spiked with $500 \mu \mathrm{L}$ of ${ }^{209}$ Po tracer (National Institute of Standards and Technology (NIST), SRM-4326A) that allows for the 
quantification of ${ }^{210} \mathrm{Po}$. The tracer ${ }^{209} \mathrm{Po}$ was used because it does not occur in nature and has a half-life of 102 years. Polonium-210 is a naturally occurring, alpha emitting radionuclide (Rani et al. 2014). A major assumption of this method is that ${ }^{210} \mathrm{Po}$ and ${ }^{210} \mathrm{~Pb}$ are in equilibrium with one another (Persson and Holm 2011). Samples received multiple treatments with the three concentrated acids $\left(\mathrm{HF}, \mathrm{HNO}_{3}, \mathrm{HCl}\right)$ under heat $\left(\sim 110-135^{\circ} \mathrm{C}\right)$ until the sediment was completely dissolved. Samples were then brought up in $50 \mathrm{ml}$ of 1.5 normal $\mathrm{HCl}$, heated to $100^{\circ} \mathrm{C}$, and stirred for 15 minutes. Ascorbic acid was then added to bind free Fe in the solution (e.g., Narita et al., 1989; Miura et al., 1999; Vesterbacka and Ikaheimonen, 2005). Silver plates $\left(1 \mathrm{~cm}^{2}\right)$ were added to each sample and allowed to set at $100^{\circ} \mathrm{C}$ for 2.5 hours as the sample was stirred. Polonium in solution was bound to the silver plates (e.g., Santschi et al., 1999; Poet et al., 1972), which were then analyzed using a Canberra 7200 Integrated Alpha spectrometer.

\subsubsection{Gamma Spectrometry}

Gamma spectrometry was used to determine activity concentrations of ${ }^{137} \mathrm{Cs}$ and ${ }^{7} \mathrm{Be}$. Homogenized samples were placed into $10 \mathrm{ml}$ test tubes and packed at a ratio of $1 \mathrm{~g}: 1$ $\mathrm{ml}$ to match all standards used. The sediment standards used included Ocean Sediment Powder (NIST, SRM-4357) and Rocky Flats Soil Number 2 (NIST, SRM-4353A). To ensure that equal geometries were obtained, samples received small additions of silica gel (if needed) as filler. Samples were then sealed with epoxy and allowed to grow into equilibrium for 21 days to prevent radon $\left({ }^{222} \mathrm{Rn}\right)$ from escaping the sample. Samples were then analyzed using Canberra High Purity Germanium well detectors and multi-channel analyzers (DSA-1000). 


\subsection{Particulate Organic Carbon and Stable Carbon Isotopes}

POC concentrations were determined, and used to derive POC inventories within, and fluxes to these sediments. Stable carbon isotope analysis of organic carbon was used to characterize the source of plant material at each site (Hobbie and Werner 2004). All aliquots for POC and stable isotopes were analyzed at the Kentucky Stable Isotope Geochemistry Laboratory (KSIGL), Department of Earth and Environmental Sciences, at the University of Kentucky. Carbon isotope data were compared with radionuclide data to identify and constrain, if possible, the timeframe when the dominant vegetation at study sites shifted from C4- to C3-dominated. C4 pathway plants are predominately grasses, while all trees utilize the $\mathrm{C} 3$ pathway. While $\mathrm{C} 4$ pathway plants are usually grasses, there are some grasses that are C3 plants. All of the sites originally had drainage basins that were originally forests (C3). Some sites were cleared of vegetation and reclaimed using different grasses $(\mathrm{C} 4)$ and afterwards trees were planted, or allowed to naturally regenerate. This change in isotopic values was used to determine if OC stored in these sediments recorded the transitions.

Stable isotopic values of carbon derived from OM present in soils and sediments are commonly coupled with geochronology to infer past climatic shifts as reflected by major changes in vegetation, including changes from cooler climate $\mathrm{C} 3$ pathway plants, to warmer climate C4 pathways plants (e.g., Phillips and Gregg, 2001; Stevenson et al., 2005; Kohn, 2010). Plant matter acts as a reservoir for atmospheric carbon (Bernoux et al., 1998; Peterson and Fry 1987), which is isotopically fractionated depending on plant type. Values of $\delta^{13} \mathrm{C}$ from organic sources (i.e., plant matter in soil) were compared with known value ranges of differing photosynthetic pathways; $\delta^{13} \mathrm{C}$ values for $\mathrm{C} 3$ pathway 
plants (forests) range from $-20 \%$ to $-35 \%$, and $\mathrm{C} 4$ pathways (grassland) have a range of 11\% to - $15 \%$ (Dawson et al., 2002; Kohn, 2010). Isotopic ratios of carbon are expressed in the form:

$$
X=\left(\frac{R_{\text {Sample }}-R_{\text {Standard }}}{R_{\text {Standard }}}\right) \times 1000
$$

where $\mathrm{X}$ represents $\delta^{13} \mathrm{C}$, and R represents ${ }^{13} \mathrm{C} /{ }^{12} \mathrm{C}$.

The supplies of organic carbon and nitrogen to soils in eastern Kentucky are primarily controlled by atmospheric inputs, OM decay, microbial processes, and the types and densities of in situ vegetation (e.g., Compton et al., 2007; Updegraff et al., 1995; Fornara and Tilman, 2008). POC inventories have been calculated for the upper $10 \mathrm{~cm}$ of all study sites, and POC fluxes were calculated for all sites where sediment accumulation rates could be determined. For trenched sites, the surface is represented by the first measurement taken from $0-2 \mathrm{~cm}$. In push cores, the surface is represented by the mean of the POC measurements taken at the $0-1$ and $1-2 \mathrm{~cm}$ intervals.

Sample aliquots for stable carbon isotope and POC analyses were bathed in dilute $\mathrm{HCl}(10 \%)$ and heated in an oven for 1 hour at $100^{\circ} \mathrm{C}$ to remove inorganic carbon. Then samples were filtered, dried, weighed, and rolled into tin capsules ( $\sim 5 \mathrm{mg})$. Each sample was then run through an elemental analyzer (Costech ECS 4010 EA), and from there into an isotope ratio mass spectrometer (Thermo Finnigan Delta Plus XP, Thermo Fisher Scientific, Inc.) by continuous flow through (Conflo IV, Thermo Fisher Scientific, Inc.). All POC and stable isotope samples have been compared against certified standards, including Acetanilide (SRM-141D), USGS 40 (SRM-8573), USGS 41 (SRM-8574), and NIST (SRM-1515). All data collected were corrected for drift and linearity. Calculated 
carbon isotope values were compared to the international Vienna PeeDee Belemnite (VPDB) standard (O’Leary 1988).

\section{CHAPTER THREE: RESULTS}

\subsection{Reclaimed Mine Land Digital Elevation Models (DEM)}

High resolution DEMs have been acquired for all sites using ArcGIS to aid in the identification of valley fills near study sites RFGC, VFWB, BM_07, and SFMC (Figure 4) and logging sites RFMS, RFFB, and FCA (Figure 5). No valley fills were found within the sub-basins of any of the logging sites. The Star Fire (SFMC) and Bent Mountain (BM_07) are located on top of valley fills unlike RFGC and VFWB that are below valley fills. Five separate valley fills are located within the sub-basin including the study site at Guy Cove (RFGC). 

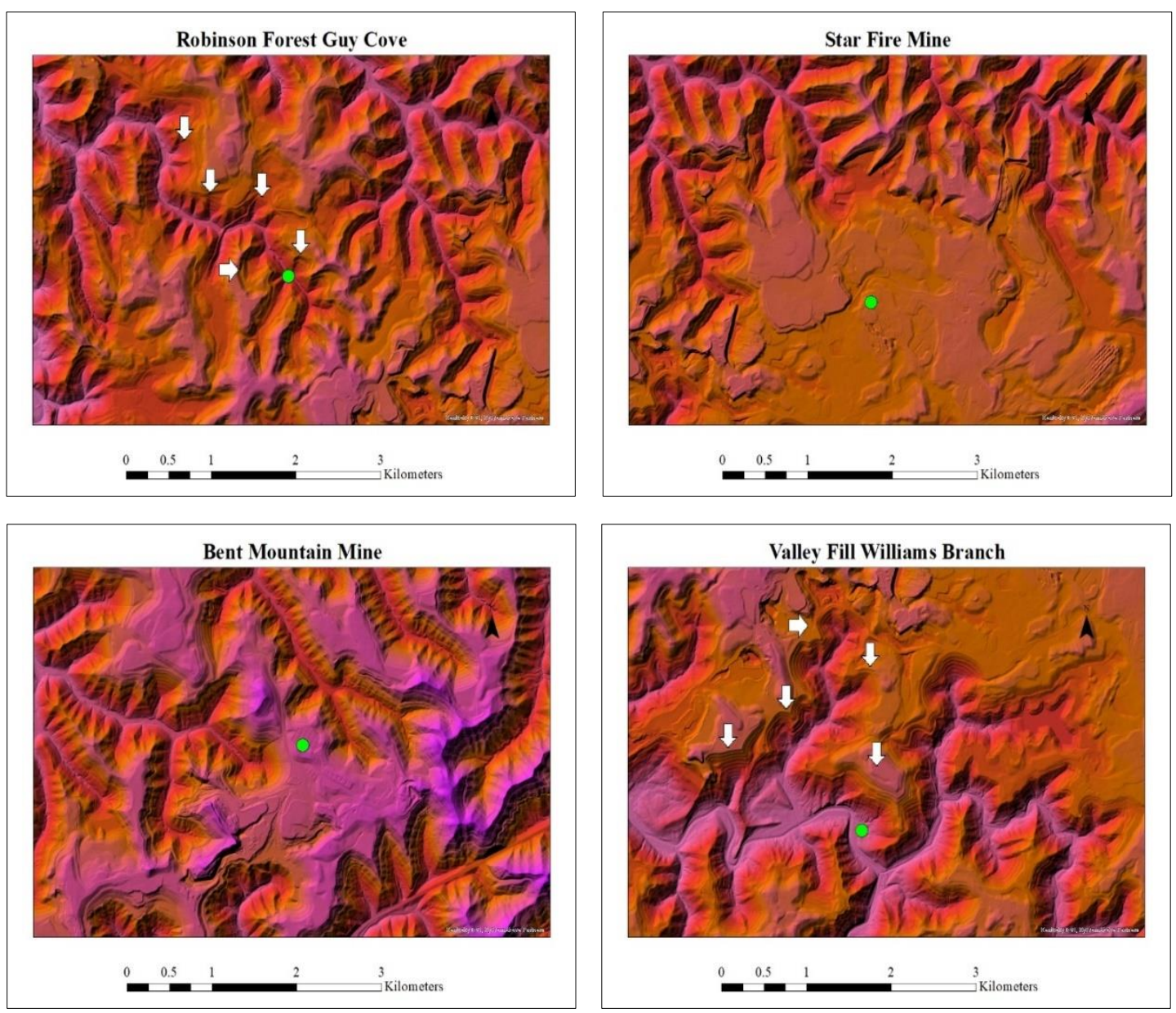

Figure 4. High resolution DEMs of reclaimed mine lands around study sites at Robinson Forest Guy Cove (top left - RFGC), Star Fire Mine (top right - SFMC), Bent Mountain Mine (lower left - BM), and Valley Fill Williams Branch (bottom right - VFWB). Valley fills near VFWB and RFGC are shown by white arrows.

These valley fills can be identified by terraced topographic areas. The study site VFWB lives up to its name with the presence of a large valley fill located to the north of the sampling site and four additional valley fills near the site for a total of five, all within the sub-basin that includes this site. The valley fills located at RFGC are all downstream of the site where cores and trenches were collected and do not affect the site. The five valley fills around VFWB do not affect the sampling site is in an isolated tributary. 

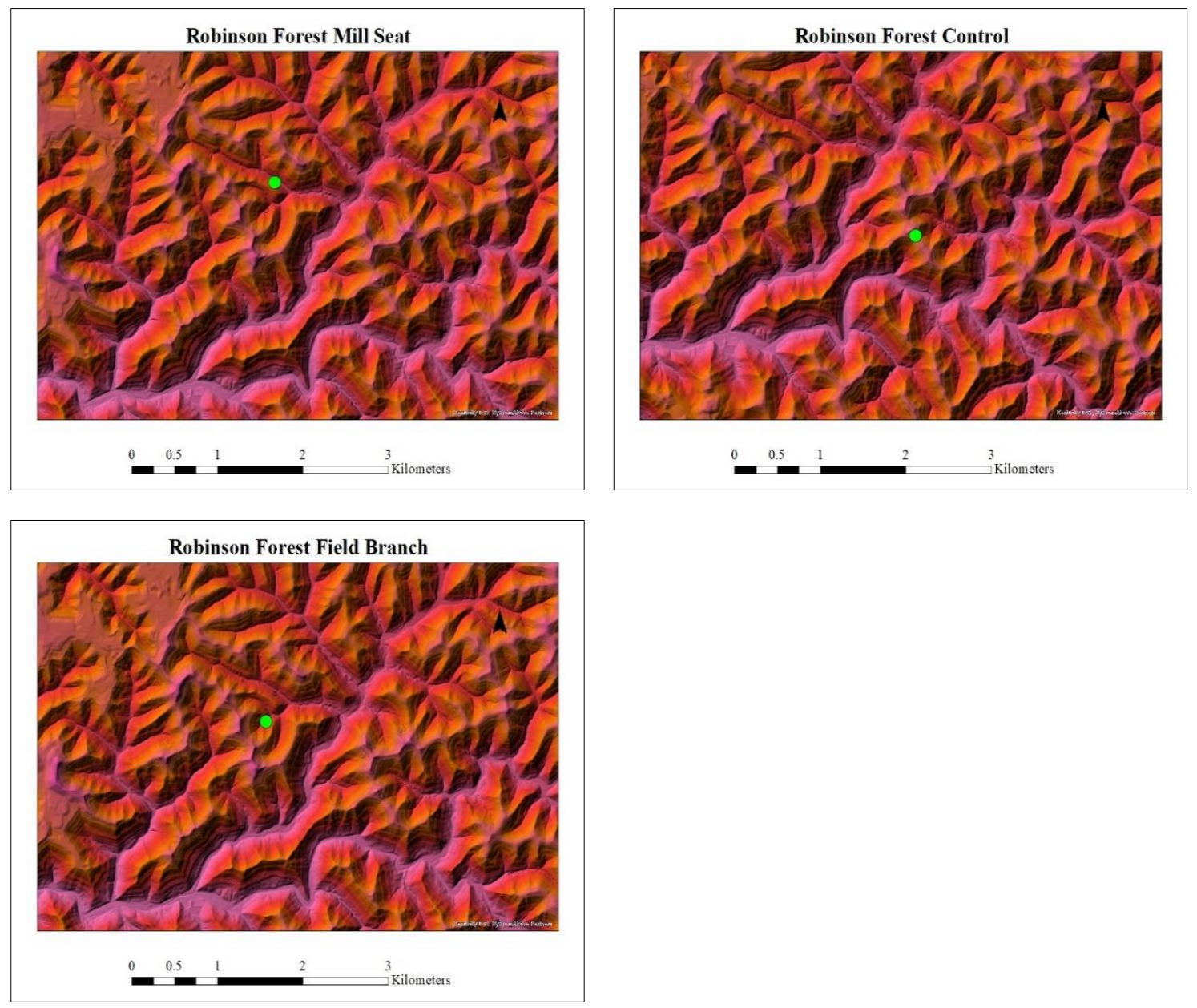

Figure 5. High resolution DEMs of logged areas around study sites at Robinson Forest Millseat (top left - RFMS), Forestry control (top right - FCA), and Field branch (bottom left - RFFB).

\subsection{Robinson Forest Satellite Imagery and Sub-Basins}

Satellite images from 2016 (Google Earth) were used to outline sub-basins for all sites. Satellite images from 1994 to 2016, taken at an altitude of approximately 15 miles, have been used to identify land scarring due to mining activity and overlaid on sub-basins to show how much of each was mined. Changes in mining activity are listed in Appendix A. The logged sites RFMS, RFFB, and FCA (Figure 6) are located within two separate 
sub-basins. RFMS and RFFB are located in the Clemons Fork sub-basin that encompasses an area of $4.20 \mathrm{~km}^{2}$. One trench was excavated at each of the sites for a total of two sampling trenches within the Clemons Fork sub-basin (RFMS_17T, RFFB_18T). FCA is located in the Coles Fork sub-basin with an area of $17.20 \mathrm{~km}^{2}$. A single trench was excavated at FCA for the Coles Fork sub-basin (FCA_15)
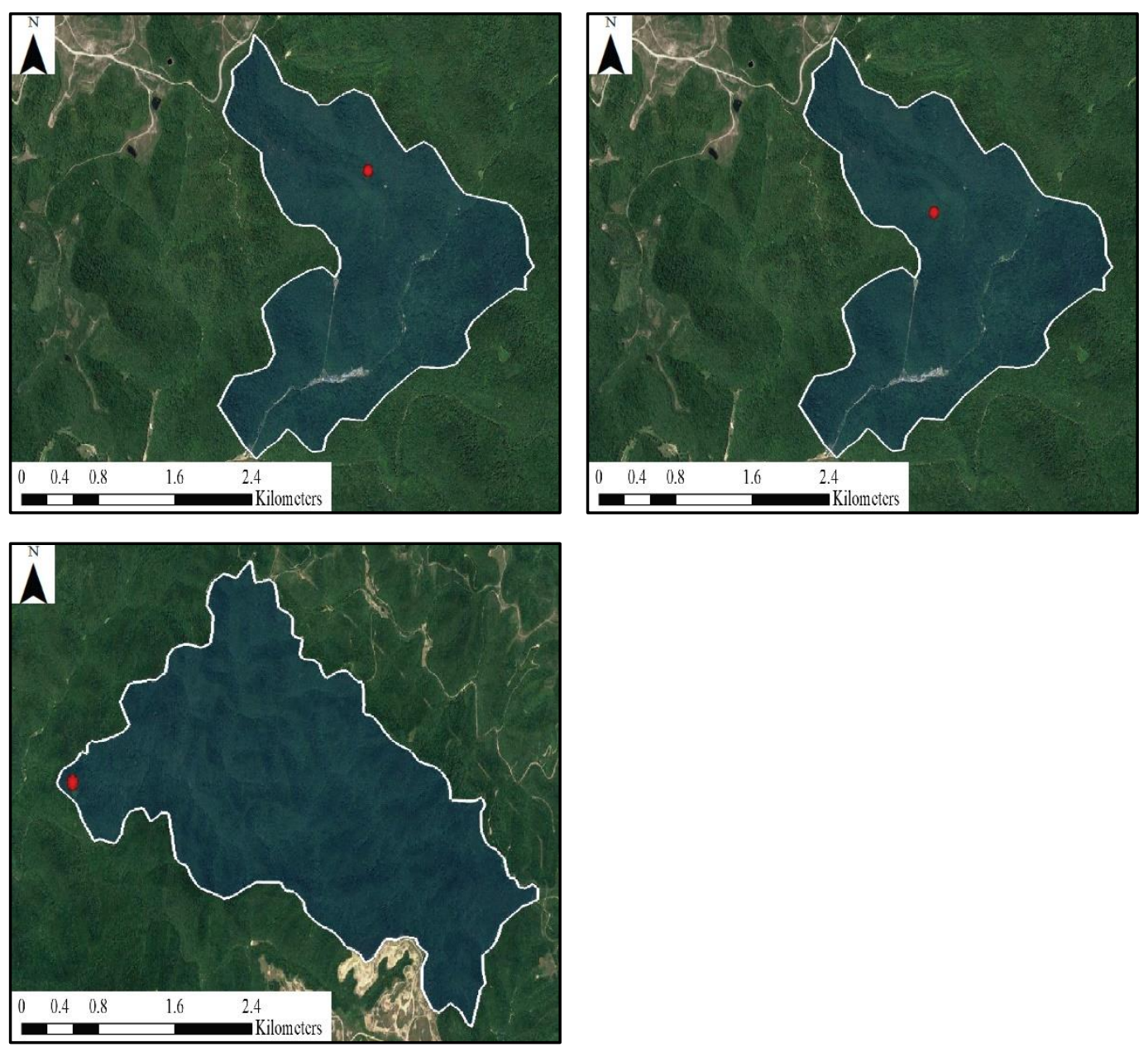

Figure 6. Satellite imagery (2016) showing the locations of previously logged sites (red) and the sub-basins (blue) within which they are located. RFMS (top left) and RFFB (top right) are both located within the Clemons Fork sub-basin. FCA (bottom left) is located within the Coles Fork sub-basin.

The mined site RFGC (Figure 7) is located within the Laurel Fork sub-basin that covers an area of $6.56 \mathrm{~km}^{2}$. In $1994, \sim 4.28 \mathrm{~km}^{2}$ of the Laurel Fork sub-basin $(65 \%)$ 
showed land scarring due to mining activity. By 1998, mining activity decreased slightly to an area of $4.21 \mathrm{~km}^{2}(64 \%)$. In 1998, RFGC was reclaimed as pastureland. RFGC was disturbed in 2008, and then reclaimed using the FRA. In images examined from 2008, and from 2016, no land scarring from mining was evident within the Laurel Fork subbasin. Changes in mined area for the Laurel Fork sub-basin are shown in Figure 8. Once trench and two push cores were collected from the Laurel Fork sub-basin from RFGC (RFGC_17T, RFGC_17PC_A, RFGC_17PC_B).
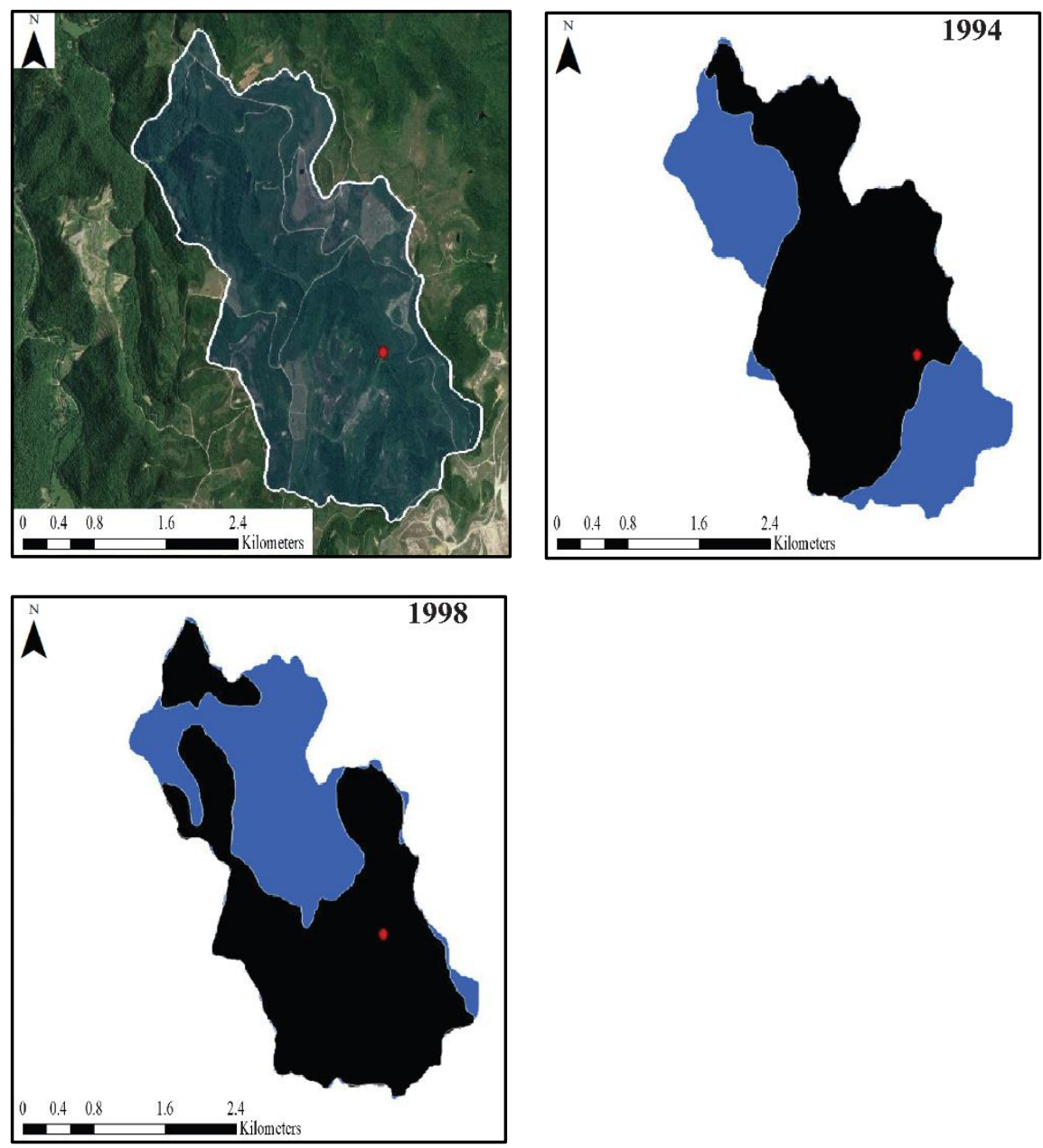

Figure 7. Satellite imagery (2016) showing RFGC (red) and its location within the Laurel Fork sub-basin (blue). Barren areas of the sub-basin (black) are shown for 1994, and 1998. 


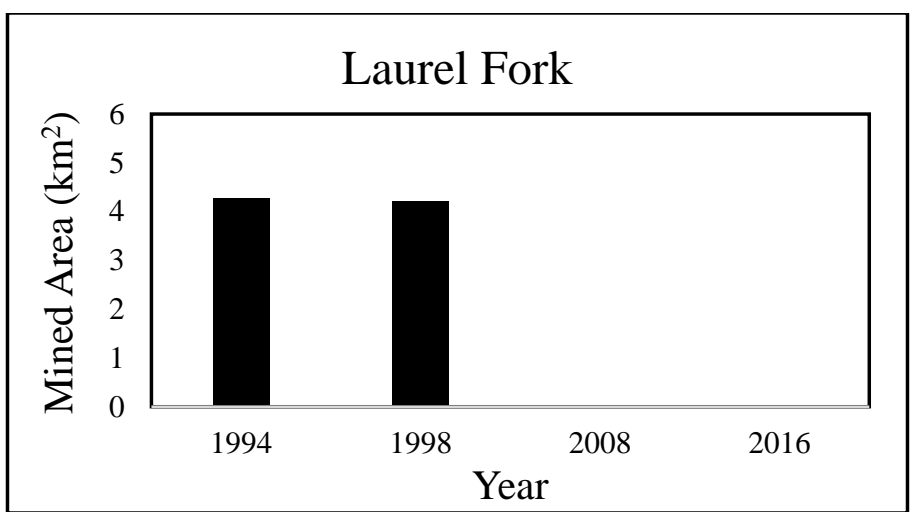

Figure 8. Changes in mining activity for the Laurel Fork sub-basin from 1994-2016.

The mined site SFMC (Figure 9) is located within the Long Fork sub-basin that covers an area of $10.80 \mathrm{~km}^{2}$. In $1994,1.10 \mathrm{~km}^{2}$ of the Long Fork sub-basin (10\%) had been mined. In 1997, SFMC was reclaimed using the FRA, but mining within the Long Fork sub-basin continued. By 1998, mining had increased to cover an area of $3.34 \mathrm{~km}^{2}$ (31\%). In 2008, mining decreased to an area of $3.13 \mathrm{~km}^{2}(29 \%)$, and by 2016 , it had increased to its maximum extent, covering $4.34 \mathrm{~km}^{2}$ (40\%). Changes in land scarring from mining are shown in Figure 10. A single sampling trench was excavated from SFMC within the Long Fork sub-basin (SFMC_15). 

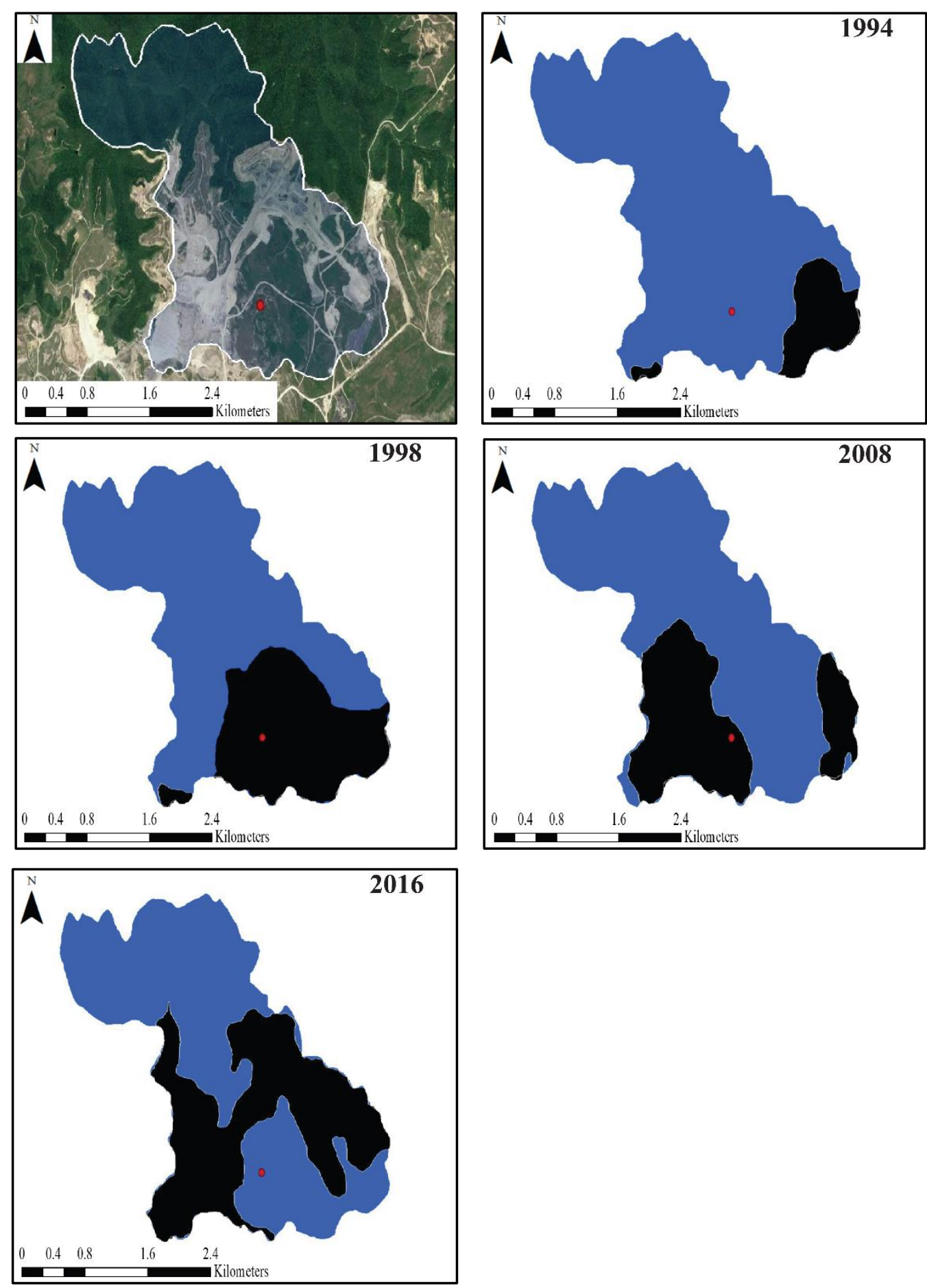

Figure 9. Satellite imagery (2016) showing SFMC (red) and its location within the Long Fork sub-basin (blue). Barren areas of the sub-basin (black) are shown for 1994, 1998, 2008, and 2016. 


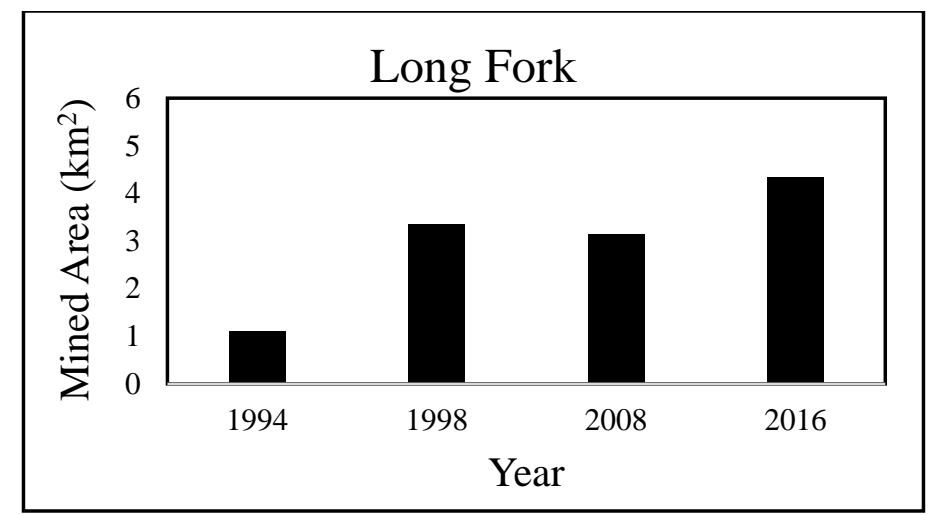

Figure 10. Changes in mining activity for the Long Fork sub basin from 1994-2016.

VFWB (Figure 11) is located in the Troublesome Creek sub-basin that encompasses an area of $8.17 \mathrm{~km}^{2}$. In 1994, there was no land scarring from mining within the subbasin. In $1998,0.11 \mathrm{~km}^{2}$ of the Troublesome Creek sub-basin (1\%) had been mined, and this increased to its maximum extent of $2.51 \mathrm{~km}^{2}(31 \%)$ in 2008. In 2013, VFWB was reclaimed as pastureland, and by 2016, mining activity decreased to an area of $0.88 \mathrm{~km}^{2}$ (11\%). Changes in mining activity for VFWB are shown in Figure 12. One push core was sampled from VFWB within the Troublesome Creek sub-basin (VFWB_17PC_A).

\subsection{Bent Mountain Satellite Imagery and Sub-Basins}

The mined site at BM (Figure 13) is located in the Brush Fork sub-basin that covers an area of $28.40 \mathrm{~km}^{2}$. In 1994, mining covered $\sim 1.92 \mathrm{~km}^{2}$ of the sub-basin (7\%). In 1998 , land scarring decreased to $1.22 \mathrm{~km}^{2}$ (4\%). In 2004, the site was reclaimed using the FRA, but mining within the sub-basin continued. By 2008, the mining area increased to its maximum extent at $3.79 \mathrm{~km}^{2}(13 \%)$. By 2016, land scarring decreased to an area of 1.74 $\mathrm{km}^{2}(6 \%)$. Changes in land scarring from mining activity for BM are shown in Figure 14. One sampling trench was excavated from the Bent Mountain mines within the Brush Fork sub-basin (BM_07). 

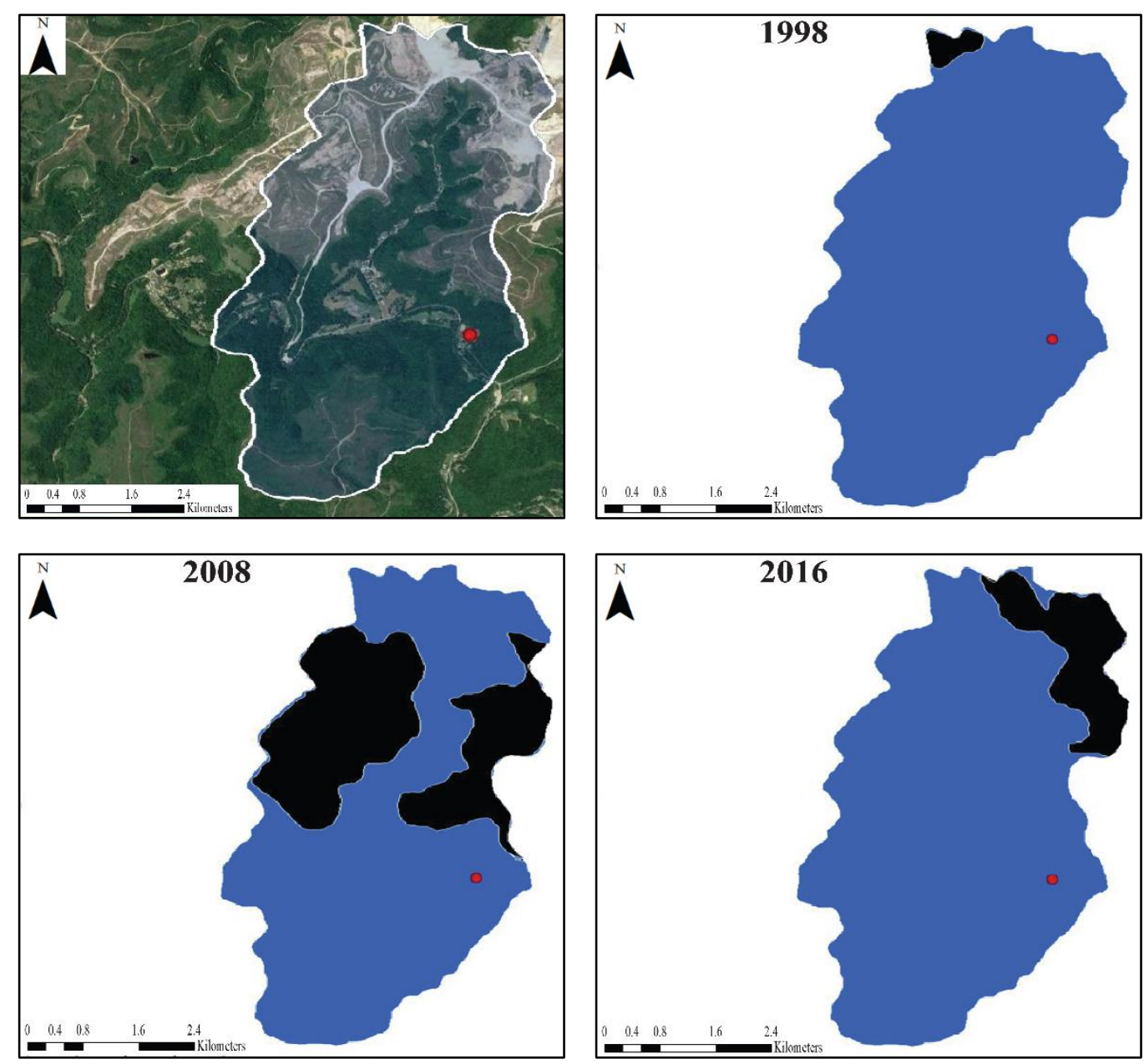

Figure 11. Satellite imagery (2016) showing VFWB (red) and its location within the Troublesome Creek sub-basin (blue). Barren areas of the sub-basin (black) are shown for 1998, 2008, and 2016.

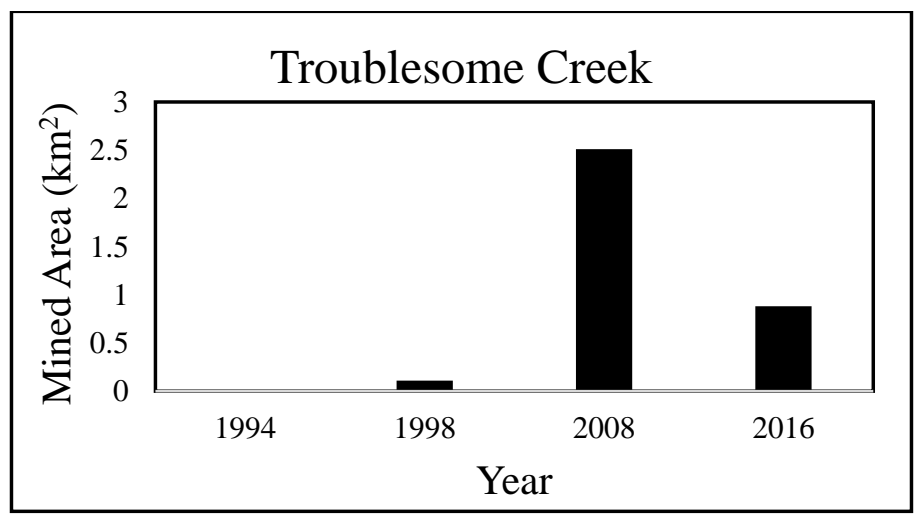

Figure 12. Changes in mining activity for the Troublesome Creek sub basin from 19942016. 

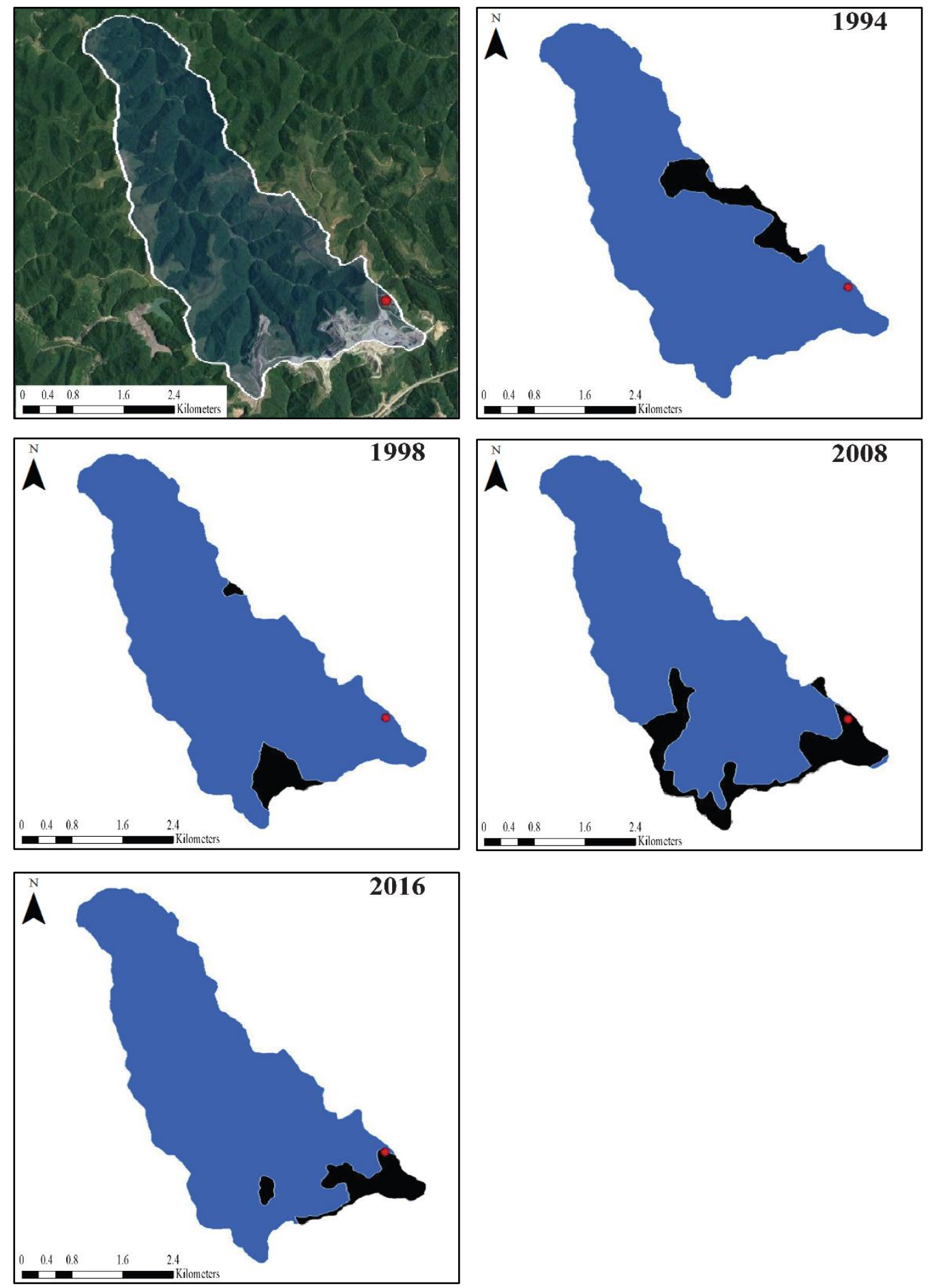

Figure 13. Satellite imagery (2016) showing BM (red) and its location within the Brush Fork sub-basin (blue). Barren areas of the sub-basin (black) are shown for 1994, 1998, 2008, and 2016. 


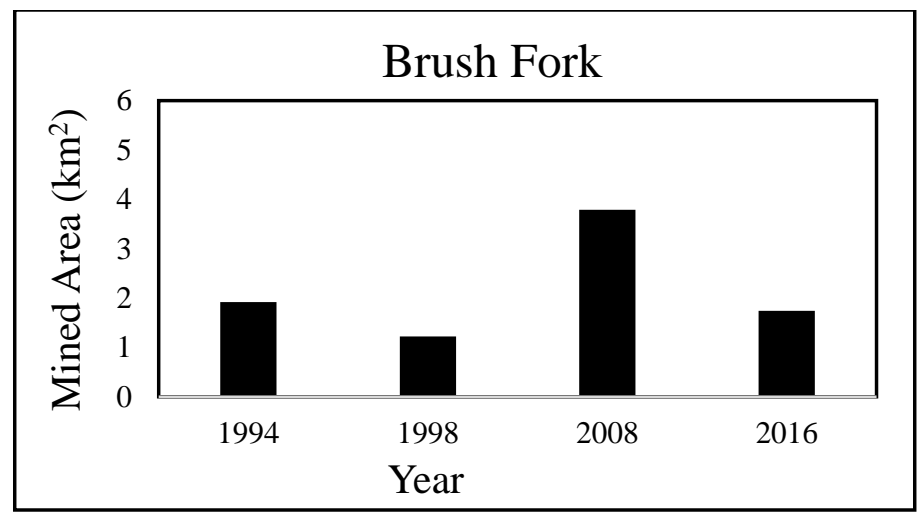

Figure 14. Changes in mining activity for the Brush Fork sub-basin from 1994-2016.

\subsection{Grain Size Distributions}

Grain size distribution data were compiled for all cores and trenches sampled. Analysis of push cores was completed at $1 \mathrm{~cm}$ intervals from $0-50 \mathrm{~cm}$, and at $2 \mathrm{~cm}$ intervals from $50 \mathrm{~cm}$ to the end of the core. Trenches were quantified at $2 \mathrm{~cm}$ intervals. All grain size results are summarized in Appendix A.

The control site trenches RFMS _17T and FCA_15 (Figure 15) were analyzed to a depth of $50 \mathrm{~cm}$. RFMS _ $17 \mathrm{~T}$ was sampled at $2 \mathrm{~cm}$ intervals over its entire depth, whereas FCA_15 was sampled at $2 \mathrm{~cm}$ intervals to $20 \mathrm{~cm}$ depth, and then at $5 \mathrm{~cm}$ intervals over the remaining depth. RFMS_17T sediments are predominantly sands (43-69\%), then silts (20-46\%), gravels (4-22\%), and minor amounts of clay sized particles (0.9-5\%). This trench does have a fining upward sequence from $0-16 \mathrm{~cm}$. Data below $16 \mathrm{~cm}$ are more erratic, with a large spike in gravel at $36 \mathrm{~cm}(33 \%)$. FCA _ 15 is dominated by silts from $10-50 \mathrm{~cm}(39-57 \%)$, and contains a low percentage of clay-sized particles $(2-14 \%)$. The upper $10 \mathrm{~cm}$ of the trench shows a noticeably higher amount of gravels (36-75\%). There is an overall fining downward sequence at FCA_15. 
RFGC_17T and RFFB_18T were sampled to depths of $26 \mathrm{~cm}$ and $22 \mathrm{~cm}$, respectively (Figure 16), and both were sampled at $2 \mathrm{~cm}$ intervals over these depths. RFGC_17T sediments are predominantly silts (50-63\%), and then sands $(25-44 \%)$ from $0-10 \mathrm{~cm}$. From 10-26 cm sands become dominant (50-60\%), while silts decrease (31-43\%). Small
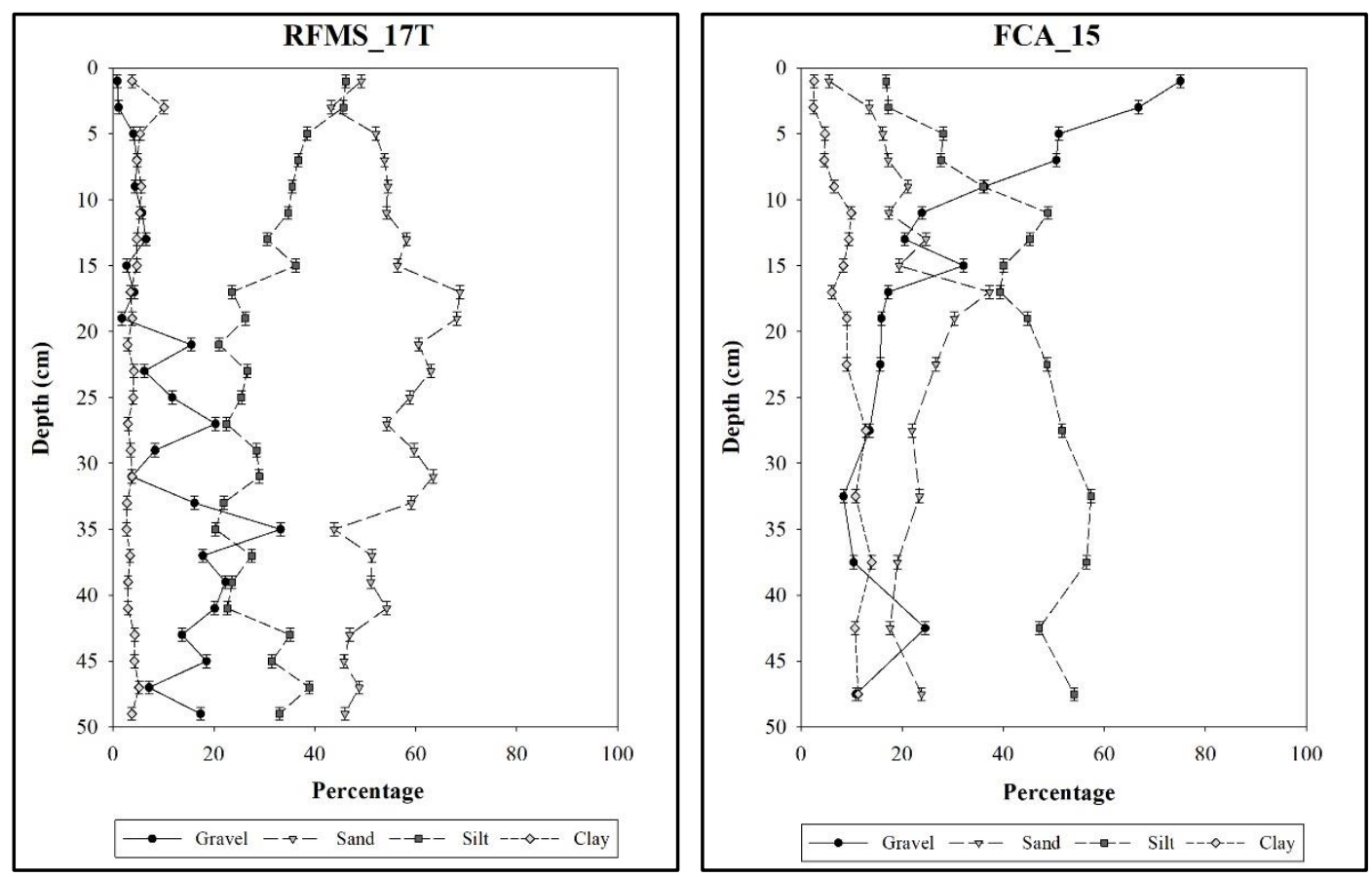

Figure 15. Grain size distributions vs. depth for control site trenches RFMS_17T (left) and FCA_15 (right).

amounts of clay-sized particles (5-11\%), and minor gravels (0.5-4\%) are present throughout the entire sampled depth and show a fining upward sequence. The dominant particle size throughout all of RFFB_18T is sand (40-63\%). Gravels and silts show similar values ( 20-30\%) over the entire sampled depth, with minor amounts of claysized particles (1-2\%). 

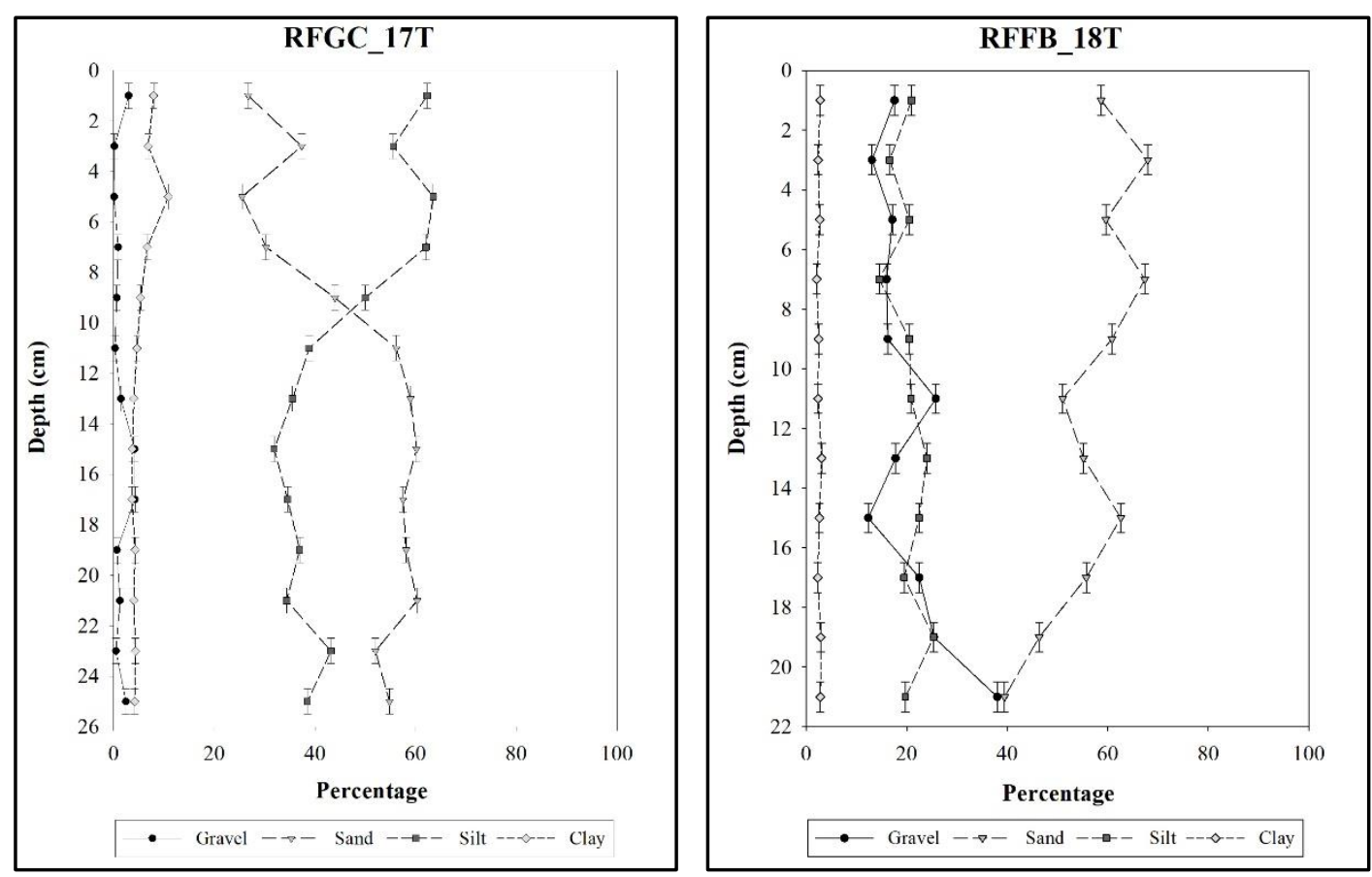

Figure 16. Grain size distributions vs. depth for trenches RFGC_17T (left) and RFFB_18T (right).

The two push cores RFGC_17PC_A and RFGC_17PC_B (Figure 17) were collected within $0.5 \mathrm{~m}$ of one another and reached depths of $96 \mathrm{~cm}$ and $98 \mathrm{~cm}$, respectively. The top $18 \mathrm{~cm}$ of both cores fine upward, with increasing amounts of silts and clay-sized particles towards the surface. Below $18 \mathrm{~cm}$, both cores exhibit a dominant mixture of sands and silts over the remaining section (with RFGC_17PC_B having more sand at depth), and both show an increase in gravels after $\sim 70 \mathrm{~cm}$.

Trenches SFMC_15 and BM_07_16 (Figure 18) were both sampled to depths of 50 $\mathrm{cm}$ and sectioned at $2 \mathrm{~cm}$ intervals for $20 \mathrm{~cm}$, and then at $5 \mathrm{~cm}$ intervals over the remainder of the sections. These two sites show large differences in particle size distributions. SFMC_15 is the only site with gravel as the dominant particle size throughout the entire profile, with values ranging from 40-90\%. After gravel, silts (8$40 \%$ ), and sands (4-15\%) make up the dominant size classes, with little clay sized 

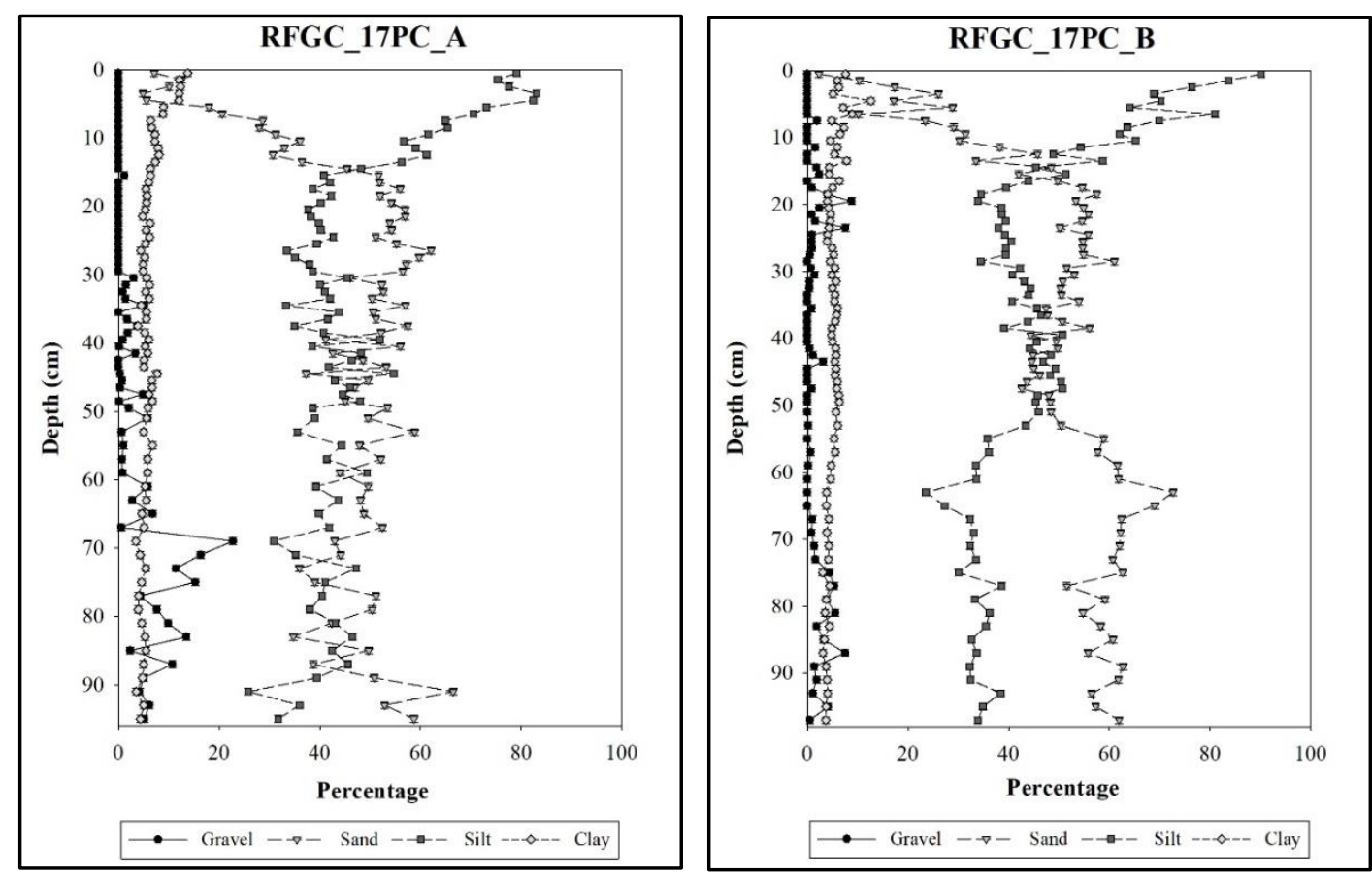

Figure 17. Grain size distributions vs. depth for push cores RFGC_17PC_A (left) and RFGC_17PC_B (right).
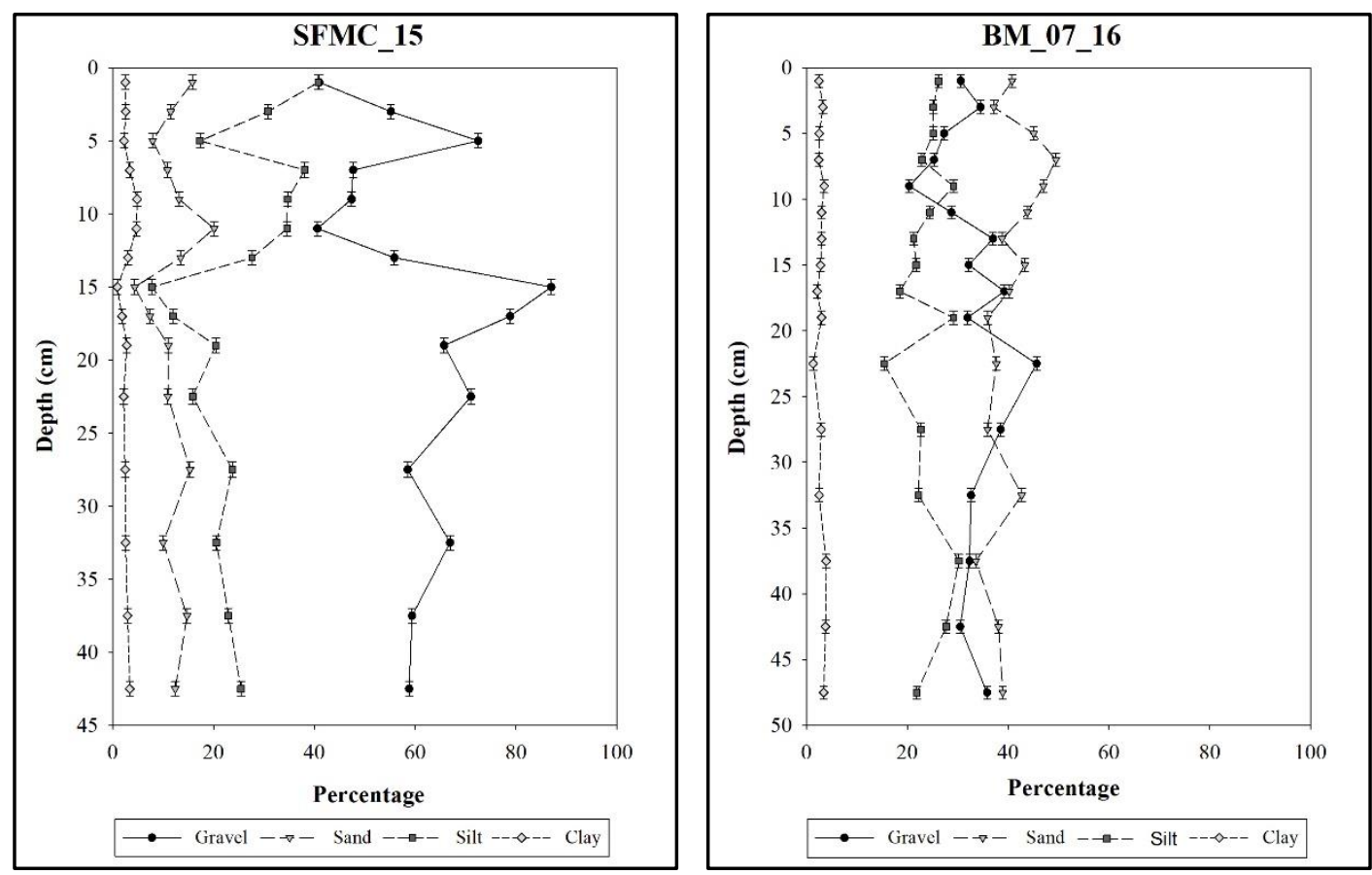

Figure 18. Grain size distributions vs. depth for trenches SFMC_15 (left) and BM_07_16 (right). 
particles present $(0.5-3.7 \%)$. BM_07_16 is dominated by sands and gravel over the whole section, with some silts $(\sim 20 \%)$, and minor clay-sized particles $(<5 \%)$.

The VFWB_17PC_A core (Figure 19) was sampled to a depth of $68 \mathrm{~cm}$. The top 6 $\mathrm{cm}$ are dominated by silts (44-70\%) with smaller amounts of sand (20-28\%). Gravels

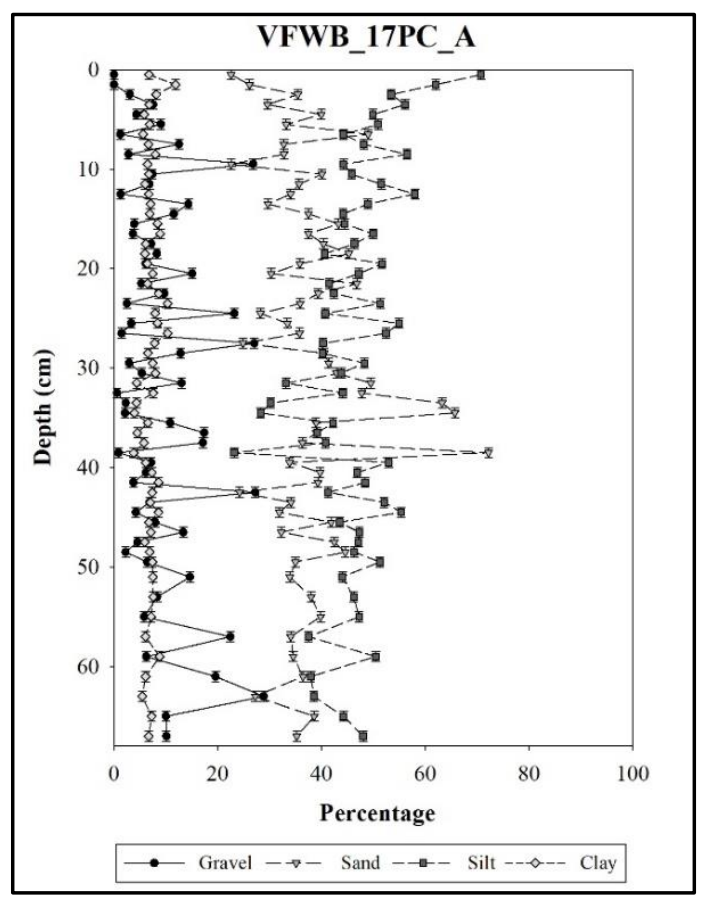

Figure 19. Grain size distribution vs. depth for push core VFWB_17PC_A.

(0.4-27\%) and clay-sized particle (5-12\%) fractions are low thoughout the core. From 6$68 \mathrm{~cm}$, the particle size distribution becomes more erratic, with sands and silts dominating, with appreciable gravel over many depth intervals, and lesser amounts (typically $\sim 10 \%$ or less) of clay-sized particles.

\subsection{Radiochemistry}

\subsubsection{Gamma Spectroscopy}

${ }^{7} \mathrm{Be}$ was resolved at four of the six trenches sampled, but was not detected in the three push cores. ${ }^{137} \mathrm{Cs}$ activity concentration profiles were constructed for three trenches and 
two push cores. All radiochemical data are provided in Appendix B. Inventories of ${ }^{137} \mathrm{Cs}$ and ${ }^{7} \mathrm{Be}$ are compared in Table 2, along with the expected ${ }^{137} \mathrm{Cs}$ inventory from atmospheric deposition alone. By comparing actual ${ }^{137} \mathrm{Cs}$ inventories to those expected from atmospheric deposition alone, a sedimentation ratio can be calculated.

Sedimentation ratio values $<1$ indicate that the site is net erosional, values $>1$ indicate that net deposition has occurred, while values $\sim 1$ indicates that erosion and deposition have been roughly equal to one another, or that no deposition (hiatus) has occurred at that site during the period of record. Based on ${ }^{137} \mathrm{Cs}$ sedimentation ratios, all sites with measurable ${ }^{137} \mathrm{Cs}$ are net depositional with the exception of RFGC_17T. This site appears to be a depositional environment, but the ${ }^{137} \mathrm{Cs}$ profile is incomplete. ${ }^{137} \mathrm{Cs}$ linear (LAR) and mass (MAR) accumulation rates for 1952 and 1963 are compared in Table 3.

Table 2. ${ }^{137} \mathrm{Cs}$ and ${ }^{7} \mathrm{Be}$ inventories for all trenches and cores. ${ }^{*}$ Indicates incomplete ${ }^{137} \mathrm{Cs}$ profile.

\begin{tabular}{|lccc|} 
Core/Trench & $\begin{array}{c}{ }^{137} \text { Cs Inventory } \\
\left(\mathrm{mBq} \mathrm{cm}^{-2}\right)\end{array}$ & $\begin{array}{c}{ }^{7} \text { Be Inventory } \\
\left(\mathrm{mBq} \mathrm{cm}^{-2}\right)\end{array}$ & $\begin{array}{c}\text { Sedimentation } \\
\text { Ratio }\end{array}$ \\
\hline Atmospheric & 135.20 & N/A & -- \\
\hline RFFB_18T & 0 & N.D. & -- \\
\hline RFMS_17T & 288.23 & 13.12 & 2.13 \\
\hline FCA_15 & 472.01 & 28.30 & 3.49 \\
\hline RFGC_17T* & 155.84 & 5.04 & 1.15 \\
\hline RFGC_17PC_A & 336.64 & N.D. & 2.49 \\
\hline RFGC_17PC_B & 393.36 & N.D. & 2.91 \\
\hline VFWB_17PC_A & 0 & N.D. & -- \\
\hline SFMC_15 & 0 & 18.72 & -- \\
\hline BM_07_16 & 0 & N.D. & -- \\
\hline
\end{tabular}


Table 3. LARs and MARs from 1952 and 1963 for sites with ${ }^{137}$ Cs data.

\begin{tabular}{|c|c|c|c|c|c|c|}
\hline Core/Trench & $\begin{array}{c}{ }^{137} \mathrm{Cs} \\
\text { LAR } \\
(1963) \\
\left(\mathrm{cm} \mathrm{yr}^{-1}\right)\end{array}$ & $\begin{array}{c}{ }^{137} \mathrm{Cs} \\
\text { LAR } \\
(1952) \\
\left(\mathrm{cm} \mathrm{yr}^{-1}\right)\end{array}$ & $\begin{array}{c}{ }^{137} \mathrm{Cs} \\
\text { MAR } \\
(1963) \\
\left(\mathrm{g} \mathrm{cm}^{-2}\right. \\
\left.\mathrm{yr}^{-1}\right)\end{array}$ & $\begin{array}{c}{ }^{137} \mathrm{Cs} \\
\mathrm{MAR} \\
(1952) \\
\left(\mathrm{g} \mathrm{cm}^{-2}\right. \\
\left.\mathrm{yr}^{-1}\right)\end{array}$ & $\begin{array}{c}\text { Mean } \\
\text { LAR } \\
\left(\mathrm{cm} \mathrm{yr}^{-1}\right)\end{array}$ & $\begin{array}{c}\text { Mean } \\
\operatorname{MAR}(\mathrm{g} \\
\left.\mathrm{cm}^{-2} \mathrm{yr}^{-1}\right)\end{array}$ \\
\hline RFMS_17T & N.D. & $\begin{array}{c}0.23 \pm \\
0.03\end{array}$ & N.D. & $\begin{array}{c}0.36 \pm \\
0.07\end{array}$ & -- & -- \\
\hline FCA_15 & N.D. & $\begin{array}{c}0.37 \pm \\
0.03\end{array}$ & N.D. & $\begin{array}{c}0.51 \pm \\
0.10\end{array}$ & -- & -- \\
\hline RFGC_17T & N.D. & N.D. & N.D. & N.D. & -- & -- \\
\hline RFGC_17PC_A & $\begin{array}{c}0.55 \pm \\
0.02 \\
\end{array}$ & $\begin{array}{c}0.68 \pm \\
0.02 \\
\end{array}$ & $\begin{array}{c}0.73 \pm \\
0.15\end{array}$ & $\begin{array}{c}0.95 \pm \\
0.19\end{array}$ & $\begin{array}{c}0.62 \pm \\
0.02\end{array}$ & $\begin{array}{c}0.79 \pm \\
0.17\end{array}$ \\
\hline RFGC_17PC_B & $\begin{array}{c}0.55 \pm \\
0.02\end{array}$ & $\begin{array}{c}0.65 \pm \\
0.02\end{array}$ & $\begin{array}{c}0.76 \pm \\
0.15\end{array}$ & $\begin{array}{c}0.96 \pm \\
0.19\end{array}$ & $\begin{array}{c}0.60 \pm \\
0.02\end{array}$ & $\begin{array}{c}0.86 \pm \\
0.17\end{array}$ \\
\hline
\end{tabular}

${ }^{7} \mathrm{Be}$ is present in the uppermost interval (0-2 cm) at site RFMS_17T (Figure 20), indicating that some limited physical or biological mixing has taken place here recently ( $\leq 1$ year). ${ }^{137} \mathrm{Cs}$ appears at $17 \mathrm{~cm}$ and its activity concentration increases moving towards the surface, however there is no clear peak in ${ }^{137} \mathrm{Cs}$ activity. This could be due to flooding that occurred within the watershed in 2009. This led to a change in the stream bed and multiple landslides. The first appearance of ${ }^{137} \mathrm{Cs}$ can be taken to represent the year 1952 , from which mass and linear accumulation rates of $0.36\left(\mathrm{~g} \mathrm{~cm}^{-2} \mathrm{yr}^{-1}\right)$ and $0.23\left(\mathrm{~cm} \mathrm{yr}^{-1}\right)$ were derived.

${ }^{7} \mathrm{Be}$ and ${ }^{137} \mathrm{Cs}$ activity concentration profiles at FCA_15 (Figure 21) were similar to those at RFMS_17T. ${ }^{7} \mathrm{Be}$ is present in the uppermost interval $(0-2 \mathrm{~cm})$ at this site, indicating that some limited physical or biological mixing has taken place here recently ( $\leq 1$ year). ${ }^{137} \mathrm{Cs}$ appears at $19 \mathrm{~cm}$ and its activity concentration generally increases moving towards the surface; however, there is no clear peak in ${ }^{137} \mathrm{Cs}$ activity. The first 
appearance of ${ }^{137} \mathrm{Cs}$ can be taken to represent the year 1952, from which mass and linear accumulations rates of $0.51\left(\mathrm{~g} \mathrm{~cm}^{-2} \mathrm{yr}^{-1}\right)$ and $0.37\left(\mathrm{~cm} \mathrm{yr}^{-1}\right)$ were derived.
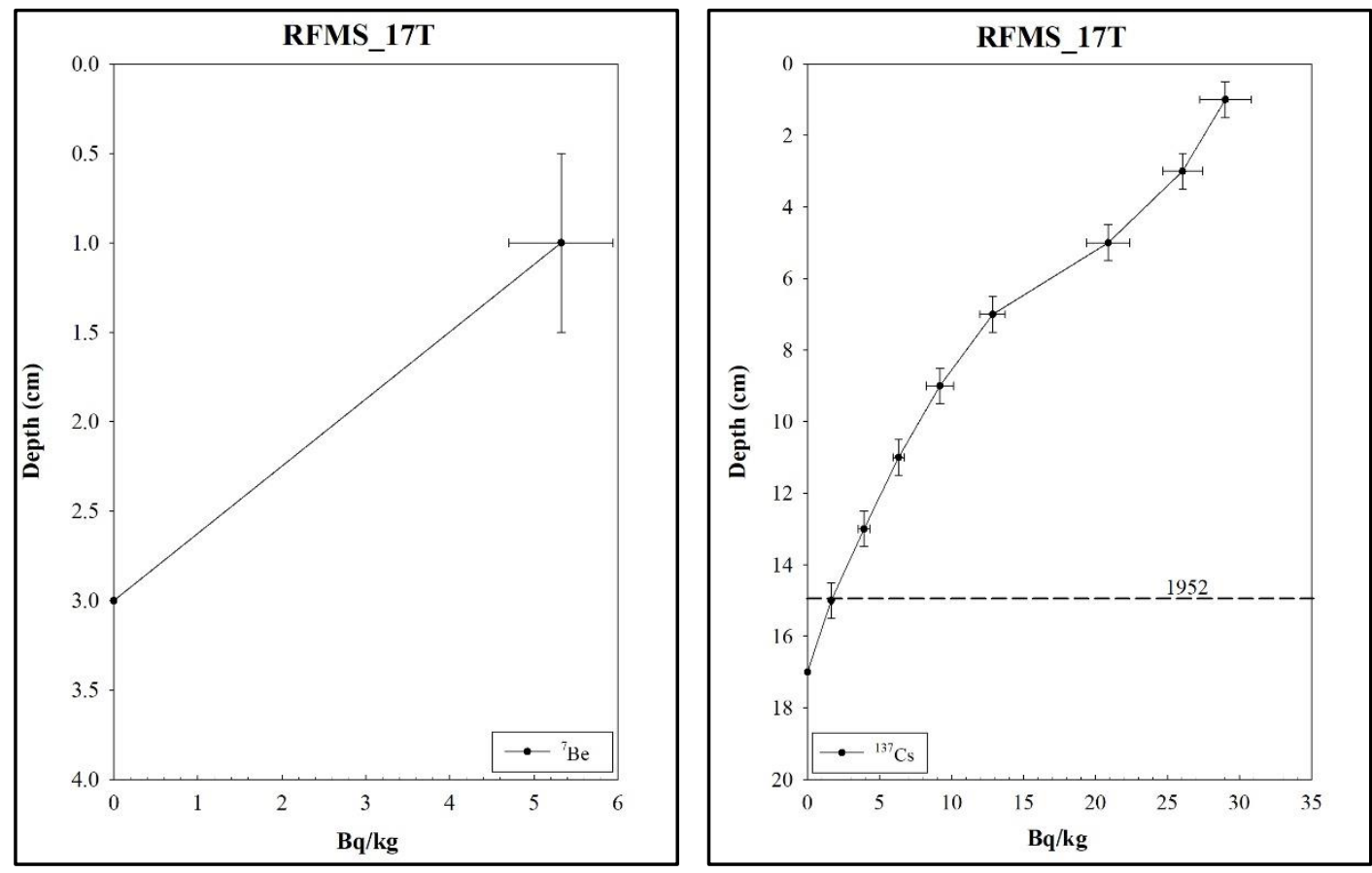

Figure $20 .{ }^{7} \mathrm{Be}$ (left) and ${ }^{137} \mathrm{Cs}$ (right) activity concentration profiles for trench RFMS_17T. The dashed line denotes the year 1952. 

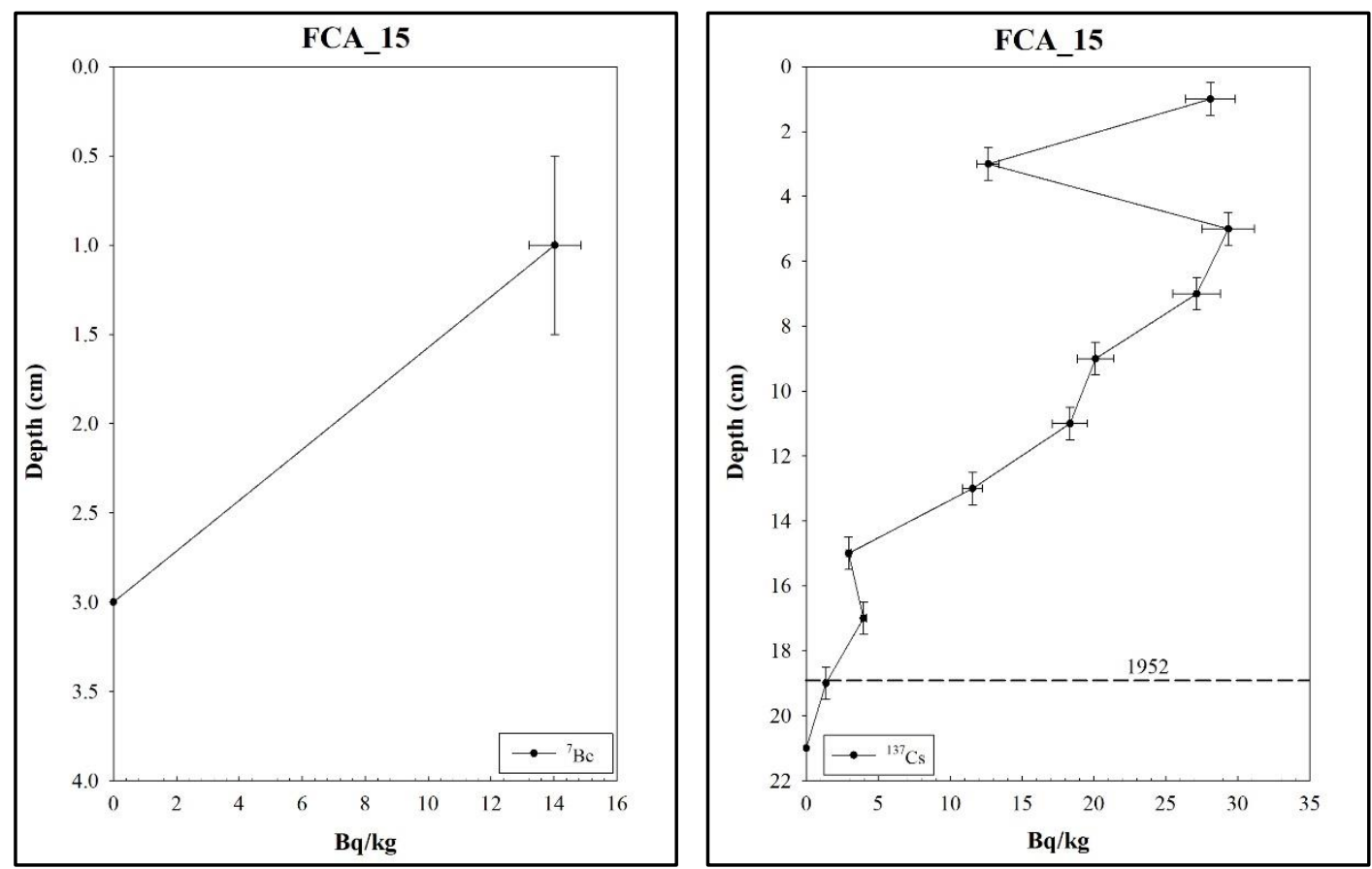

Figure $21 .{ }^{7} \mathrm{Be}$ (left) and ${ }^{137} \mathrm{Cs}$ (right) activity concentration profiles for trench FCA_15. The dashed line denotes the year 1952 .

${ }^{7} \mathrm{Be}$ is present in the uppermost interval (0-2 cm) at site RFGC_17T (Figure 22), indicating that some limited physical or biological mixing has taken place here recently ( $\leq 1$ year). The ${ }^{137} \mathrm{Cs}$ activity concentration profile appears to be truncated, and does not include the first appearance of ${ }^{137} \mathrm{Cs}$, nor a clear peak in activity (both likely due to the shallow depth of this section), making the determination of sediment accumulation rates using ${ }^{137} \mathrm{Cs}$ impossible. The two cores taken from this area, RFGC_17PC_A and RFGC_17PC_B (Figure 23), show no ${ }^{7}$ Be activity, but do provide much more complete ${ }^{137} \mathrm{Cs}$ profiles. The absence of ${ }^{7} \mathrm{Be}$ indicates no recent mixing $(\leq 1$ year). In both of these cores, ${ }^{137} \mathrm{Cs}$ activity begins around $45 \mathrm{~cm}$ (1952) and maximum activity occurs around 30 cm (1963). From 1952, RFGC_17PC_A has a mass accumulation rate of $0.95\left(\mathrm{~g} \mathrm{~cm}^{-2} \mathrm{yr}^{-}\right.$ $\left.{ }^{1}\right)$, and a linear accumulation rate of $0.68\left(\mathrm{~cm} \mathrm{yr}^{-1}\right)$. From 1963, both the mass and linear accumulation rates decrease to $0.73\left(\mathrm{~g} \mathrm{~cm}^{-2} \mathrm{yr}^{-1}\right)$ and $0.55\left(\mathrm{~cm} \mathrm{yr}^{-1}\right)$, respectively. The 
mean mass and linear accumulation rates based on ${ }^{137} \mathrm{Cs}$ for RFGC_17PC_A are 0.79 (g $\left.\mathrm{cm}^{-2} \mathrm{yr}^{-1}\right)$ and $0.62\left(\mathrm{~cm} \mathrm{yr}^{-1}\right)$, respectively. From 1952, RFGC_17PC_B has a mass accumulation rate of $0.96\left(\mathrm{~g} \mathrm{~cm}^{-2} \mathrm{yr}^{-1}\right)$ and a linear accumulation rate of $0.65\left(\mathrm{~cm} \mathrm{yr}^{-1}\right)$. From 1963, these rates decreased to $0.76\left(\mathrm{~g} \mathrm{~cm}^{-2} \mathrm{yr}^{-1}\right)$ and $0.55\left(\mathrm{~cm} \mathrm{yr}^{-1}\right)$, respectively. The mean mass and linear accumulation rates based on ${ }^{137} \mathrm{Cs}$ for RFGC_17PC_B are 0.86 $\left(\mathrm{g} \mathrm{cm}^{-2} \mathrm{yr}^{-1}\right)$ and $0.60\left(\mathrm{~cm} \mathrm{yr}^{-1}\right)$, respectively.

SFMC_15 shows no ${ }^{137} \mathrm{Cs}$ activity, but ${ }^{7} \mathrm{Be}$ is present within the upper $2 \mathrm{~cm}$ at this site, indicating that some limited physical or biological mixing has taken place here recently ( $\leq 1$ year) (Figure 24$)$. The absence of ${ }^{137} \mathrm{Cs}$ is likely due to the mining activity that has taken place at the Star Fire mines and the young age of the site post reclamation (18 yr.).
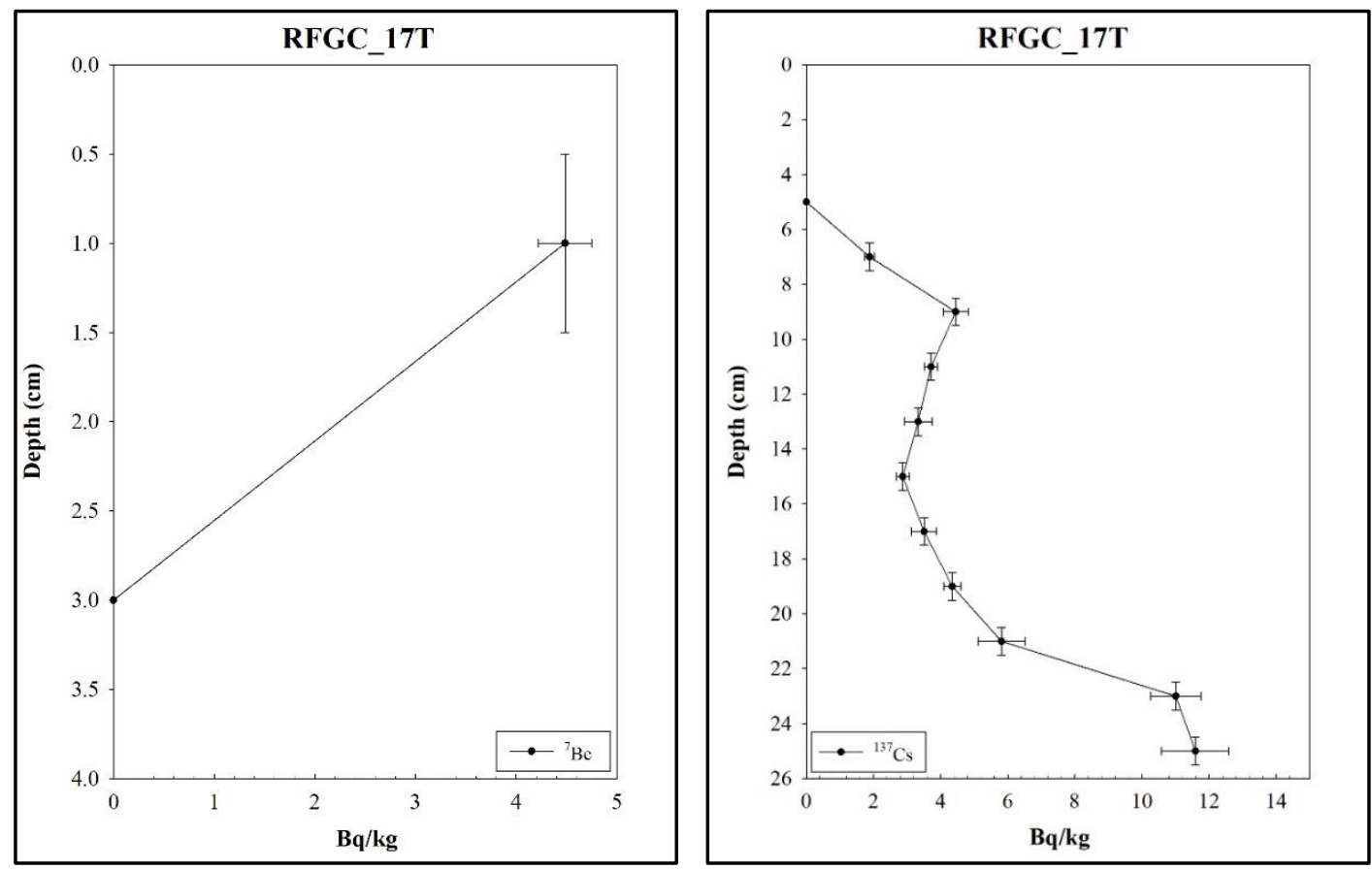

Figure $22 .{ }^{7} \mathrm{Be}$ (left) and ${ }^{137} \mathrm{Cs}$ (right) activity profiles for trench RFGC_17T. 

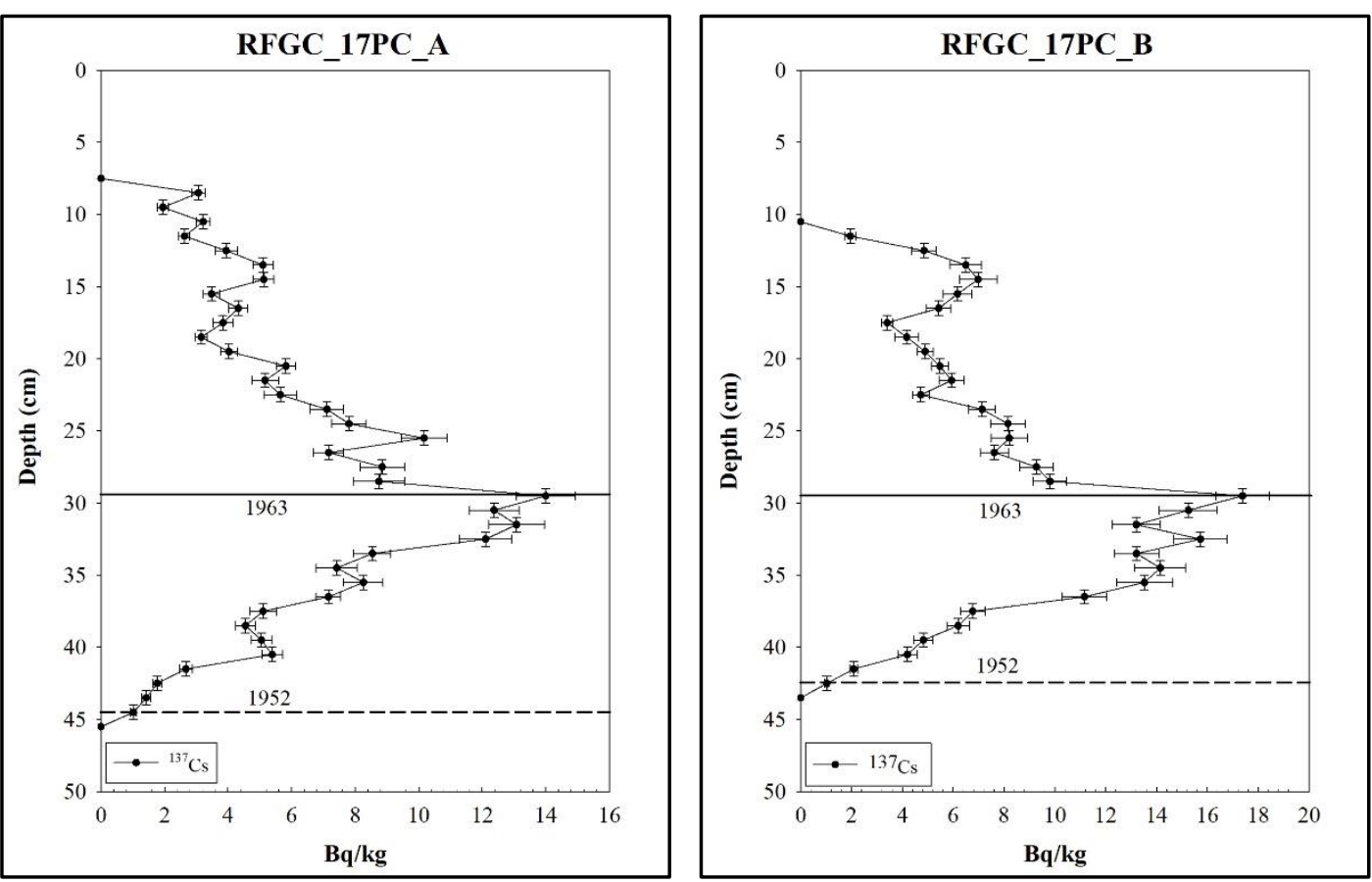

Figure $23 .{ }^{137} \mathrm{Cs}$ activity concentration profiles for push cores RFGC_17PC_A (left) and RFGC_17PC_B (right). The dashed and solid lines denote the years 1952, and 1963, respectively.

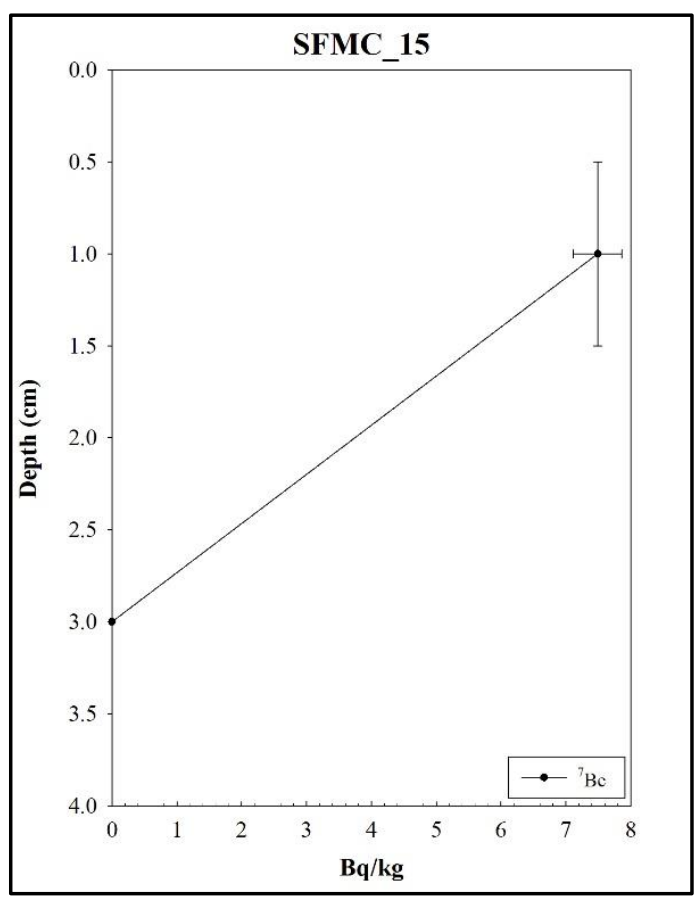

Figure $24 .{ }^{7} \mathrm{Be}$ activity profile for trench SFMC_15. 
${ }^{137} \mathrm{Cs}$ and ${ }^{7} \mathrm{Be}$ are also absent from sites VFWB_17PC_A, RFFB_18T, and BM_07_16. The lack of these radionuclides at sites VFWB_17PC_A and BM_07_16 is due the young age of these sites post reclamation (5, and 12 yrs., respectively). A lack of these radionuclides at RFFB_18T may be due to large amounts of sand sized particles at the site (see Figure 16). ${ }^{137}$ Cs-based sediment accumulation rates for all sites are presented in Figure 25.

\subsubsection{Alpha Spectroscopy and Sediment Accumulation Rates}

Alpha spectrometry was performed on five of the six trenches and all three push cores sampled. Activities of ${ }^{210} \mathrm{~Pb}$ and ${ }^{210} \mathrm{~Pb}$ ex for all sites are listed in Appendix B. Mass accumulation rates spanning $~ 100$ years BP have been summarized in Appendix D. The only site that did not yield ${ }^{210} \mathrm{~Pb}$ ex or ${ }^{137} \mathrm{Cs}$ was RFFB_18T. The mined sites SFMC and $\mathrm{BM}$ did not contain ${ }^{137} \mathrm{Cs}$, but do show ${ }^{210} \mathrm{~Pb}_{\text {ex. }}$. Grain size is similar for these three sites with very little clay present, but higher amounts of sands and gravel. Radionuclides readily absorb onto smaller grain size particles like clay and silt, but not sands or gravel (Mabit et al. 2008; He and Walling 1996; Matisoff et al. 2002). However, RFFB shows very low amounts of POC compared to SFMC and BM. The higher amounts of POC could explain the presence of ${ }^{210} \mathrm{~Pb}$ ex within the mined sites, but not at RFFB. 

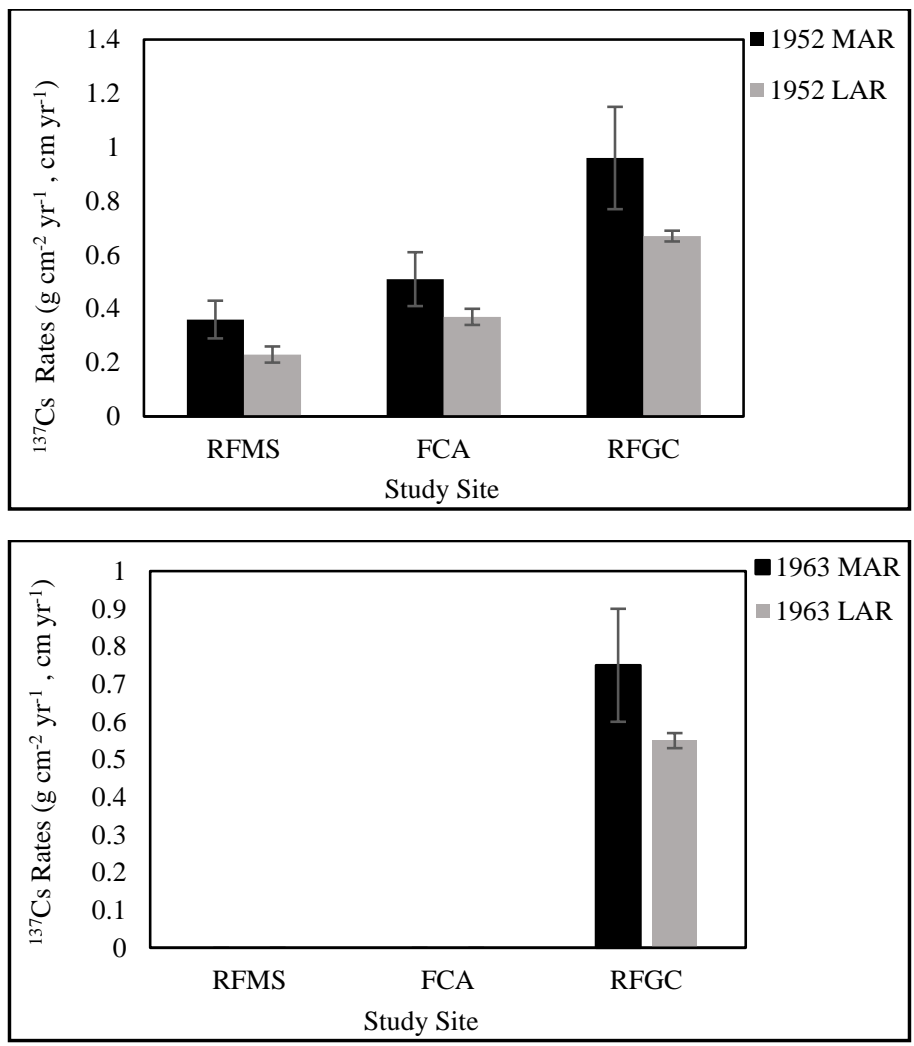

Figure 25. ${ }^{137} \mathrm{Cs}$-based sediment accumulation rates based on the 1952 (top) and 1963 (bottom) time markers for RFMS, FCA, and RFGC. Values for RFGC are based on mean values for the two push cores taken at the site. Uncertainties reported at one standard deviation.

The inventories of ${ }^{210} \mathrm{~Pb}_{\text {ex }}$ are listed in Table 4, along with the ${ }^{210} \mathrm{~Pb}$ ex inventory expected from atmospheric deposition alone, and sedimentation ratios based on ${ }^{210} \mathrm{~Pb}_{\text {ex. }}$. Sedimentation ratios indicate that RFGC_17T, VFWB, SFMC, and BM_07 show net erosion over the last century. RFMS, FCA, and both RFGC cores all show net deposition over the last century. MARs and LARs are listed in Table 5. 
Table 4. ${ }^{210} \mathrm{~Pb}$ ex inventories for all cores compared against inventories expected from atmospheric deposition alone, and sedimentation ratios.

\begin{tabular}{|ccc|}
\hline Trench/Core & ${ }^{210} \mathrm{~Pb}_{\text {ex }}$ Inventory $\left(\mathrm{mBq} \mathrm{cm}^{-2}\right)$ & $\begin{array}{c}\text { Sedimentation } \\
\text { Ratio }\end{array}$ \\
\hline Atmospheric & 537.42 & - \\
\hline RFMS_17T & 711.98 & 1.32 \\
\hline FCA_15 & $1,393.15$ & 2.59 \\
\hline RFGC_17T & 306.66 & 0.57 \\
\hline RFGC_17PC_A & $1,032.33$ & 1.92 \\
\hline RFGC_17PC_B & $2,094.61$ & 3.89 \\
\hline VFWB_17PC_A & 52.92 & 0.09 \\
\hline SFMC_15 & 410.43 & 0.76 \\
\hline BM_07_16 & 9.55 & 0.02 \\
\hline
\end{tabular}

Table 5. Comparison of average ${ }^{210} \mathrm{~Pb}_{\mathrm{xs}}$ MARs and LARs for all sites. All uncertainties reported at one sigma.

\begin{tabular}{|lcc|}
\multicolumn{1}{r}{ Trench/Core } & ${ }^{210} \mathrm{~Pb}$ ex $\mathrm{MAR}\left(\mathrm{g} \mathrm{cm}^{-2} \mathrm{y}^{-1}\right)$ & ${ }^{210} \mathrm{~Pb}$ ex LAR $\left(\mathrm{cm} \mathrm{y}^{-1}\right)$ \\
\hline RFMS_17T & $0.20 \pm 0.05$ & $0.14 \pm 0.04$ \\
\hline FCA_15 & $0.58 \pm 0.63$ & N.D. \\
\hline RFGC_17T & $0.14 \pm 0.09$ & $0.13 \pm 0.08$ \\
\hline RFGC_17PC_A & $0.22 \pm 0.15$ & $0.23 \pm 0.15$ \\
\hline RFGC_17PC_B & $1.11 \pm 1.00$ & $0.85 \pm 0.76$ \\
\hline SFMC_15 & $0.60 \pm 0.33$ & N.D. \\
\hline BM_07_16 & N.D. & N.D. \\
\hline
\end{tabular}

Analysis of RFMS_17T (Figure 26) provides mass and linear accumulation rates determined using ${ }^{210} \mathrm{~Pb}$ ex. Accumulation rates are the lowest around 80 years $\mathrm{BP}$ with values at $0.11\left(\mathrm{~g} \mathrm{~cm}^{-2} \mathrm{yr}^{-1}\right)$ and $0.08\left(\mathrm{~cm} \mathrm{yr}^{-1}\right)$. From 80 to 50 years BP rates increase to $0.23\left(\mathrm{~g} \mathrm{~cm}^{-2} \mathrm{yr}^{-1}\right)$ and $0.17\left(\mathrm{~cm} \mathrm{yr}^{-1}\right)$. After this, rates remain between 0.20 to $0.24\left(\mathrm{~g} \mathrm{~cm}^{-2}\right.$ $\left.\mathrm{yr}^{-1}\right)$ and 0.15 to $0.17\left(\mathrm{~cm} \mathrm{yr}^{-1}\right)$. The relatively strong linear regression fit for linear and mass accumulation rates $\left(\mathrm{R}^{2}=0.72 ; \mathrm{p}=0.03\right)$ indicates that sediment accumulation rates have steadily increased over time at this site. 

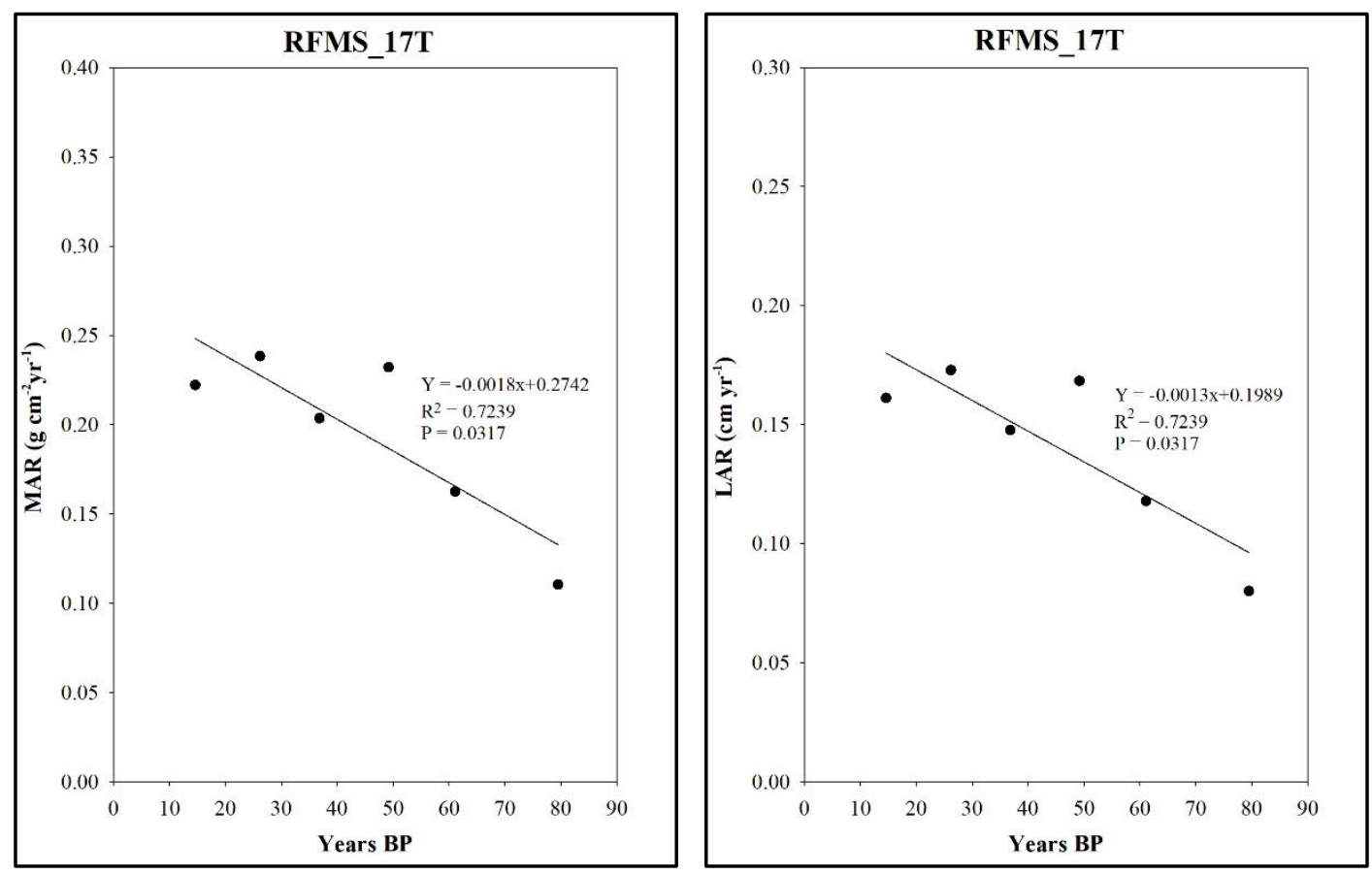

Figure 26. Sediment mass accumulation rates (left) and linear accumulation rates (right) for trench RFMS_17T.

Analysis of FCA_15 provides MAR data determined using ${ }^{210} \mathrm{~Pb}$ ex (Figure 27), spanning the last $\sim 120$ years BP. There is no LAR data for this site due to a lack of measured bulk density. The highest rates are seen at 101 years BP at $2.40\left(\mathrm{~g} \mathrm{~cm}^{-2} \mathrm{yr}^{-1}\right)$. This very high rate is likely due to logging activity that occurred up until 90 years BP around this site. Rates show a sharp decline from 100 to 80 years BP. A strong exponential regression fit $\left(\mathrm{R}^{2}=0.77 ; \mathrm{p}=0.01\right)$ from 60 years $\mathrm{BP}$ to the present shows that accumulation rates have rapidly decreased within that $60-y r$. time period. 


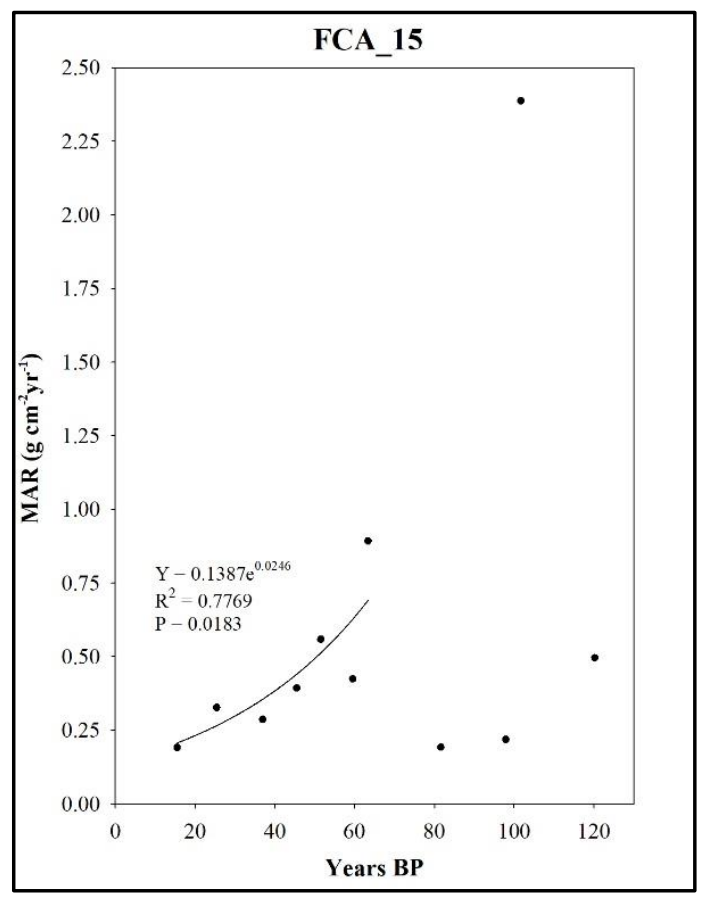

Figure 27. Sediment mass accumulation rates for trench FCA_15. Exponential regression is shown for data spanning 60 years BP to the present.

Analysis of RFGC_17T (Figure 28) begins to provide a clearer picture of the effects of the FRA as opposed to grassland reclamation. Sediment MAR and LAR are measured up to 50 years $\mathrm{BP}$, and the strong exponential regression fits $\left(\mathrm{R}^{2}=0.98 ; \mathrm{p}=0.01\right)$ indicate rapid and progressively increasing rates between 50 - and 20 -years BP, when the site was initially reclaimed as pastureland. During this period (red in Figure 28), accumulation rates were at $0.15\left(\mathrm{~g} \mathrm{~cm}^{-2} \mathrm{yr}^{-1}\right)$ and $0.14\left(\mathrm{~cm} \mathrm{yr}^{-1}\right)$. At 10 years BP, the FRA was implemented, and rates are shown to continue increasing to their maximum values, at $0.27\left(\mathrm{~g} \mathrm{~cm}^{-2} \mathrm{yr}^{-1}\right)$ and $0.24\left(\mathrm{~cm} \mathrm{yr}^{-1}\right)$. 

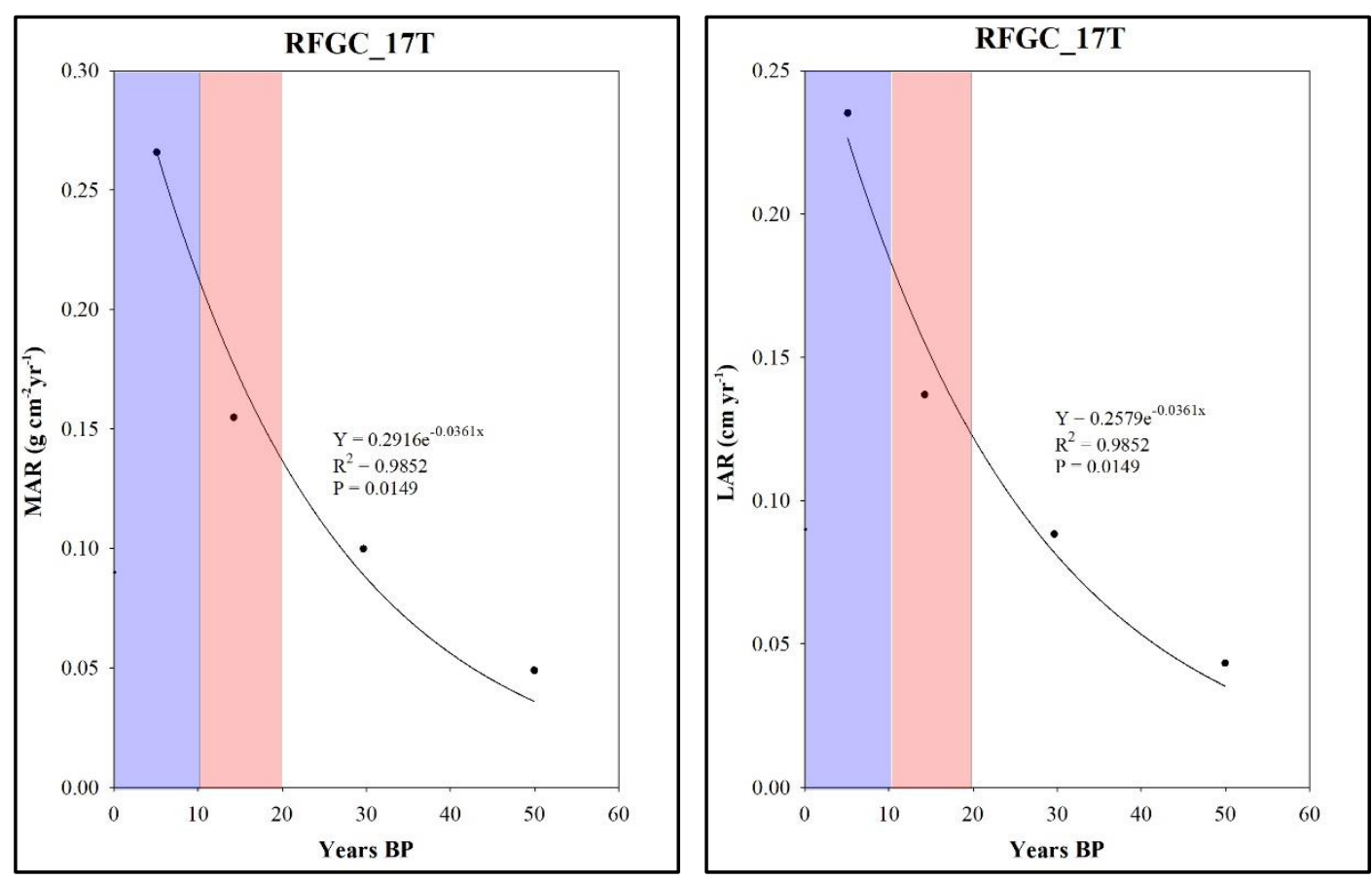

Figure 28. Sediment mass accumulation rates (left) and linear accumulation rates (right) for trench RFGC_17T. Shaded sections provide the timing of grassland reclamation (red) and the FRA (blue).

${ }^{210} \mathrm{~Pb}$ xs data from the two push cores collected in RFGC provide better resolution than the trench site at RFGC_17T. RFGC_17PC_A (Figure 29) and RFGC_17PC_B (Figure 30) exhibit large differences in both sediment MARs and LARs. Sediment accumulation rates for RFGC_17PC_A are measured up to 110 years BP. Twenty years ago, when the site was reclaimed using grassland reclamation, the rates were $0.13\left(\mathrm{~g} \mathrm{~cm}^{-2} \mathrm{yr}^{-1}\right.$, and cm $\left.\mathrm{yr}^{-1}\right)$. At 10 years BP, the FRA was implemented. At this time both MARs and LARs increased significantly to the highest values since the site was reclaimed, at $0.18\left(\mathrm{~g} \mathrm{~cm}^{-2}\right.$ $\mathrm{yr}^{-1}$, and $\left.\mathrm{cm} \mathrm{yr}^{-1}\right)$.

The average rates for RFGC_17PC_B are abnormally high when compared with all other sampling trenches and push cores. This push core did show the most robust ${ }^{210} \mathrm{~Pb}$ ex 
profile of all sampled sites. These highly elevated results are likely due to heterogeneity over small spatial scales; i.e., processes captured in the record at one core site were not captured at a second core site.
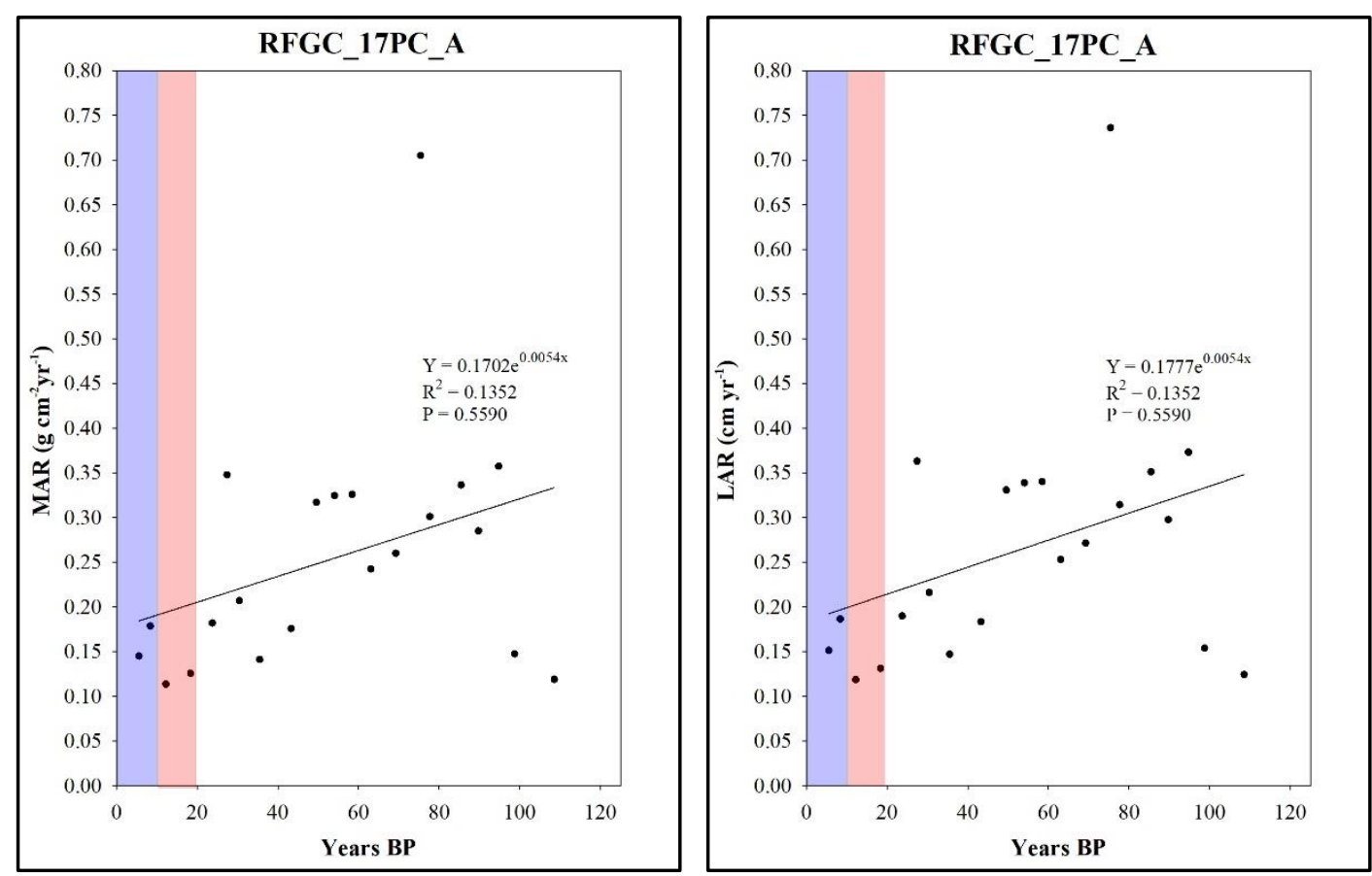

Figure 29. Sediment mass accumulation rates (left) and linear accumulation rates (right) for push core RFGC_17PC_A. Shaded sections provide the timing of grassland reclamation (red) and the FRA (blue). 

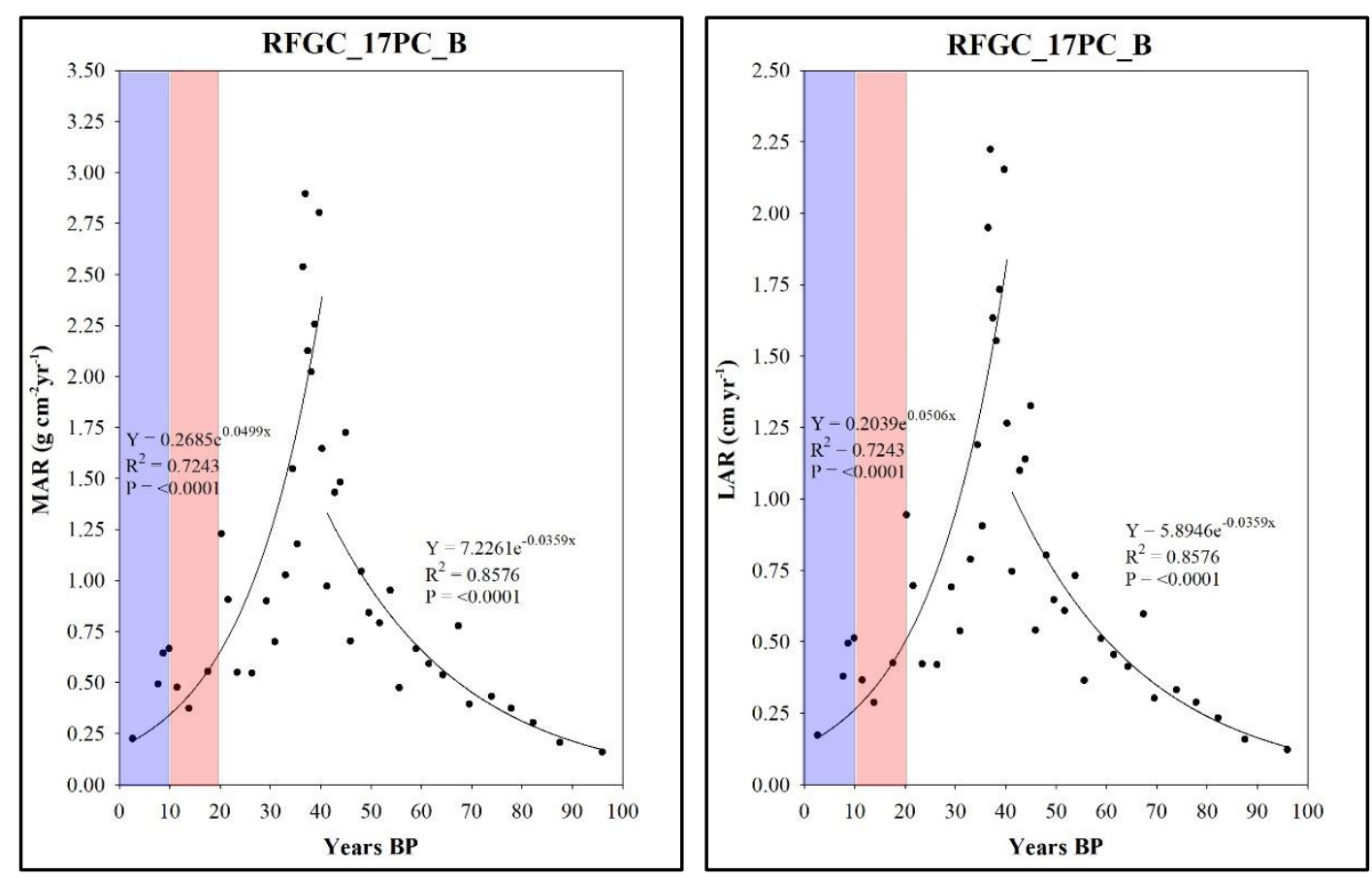

Figure 30. Sediment mass accumulation rates (left) and linear accumulation rates (right) for push core RFGC_17PC_B. Shaded sections provide the timing of grassland reclamation (red) and the FRA (blue). Exponential regression fits for 40 years BP to present are shown (left, both plots), as are fits from 40 to 100 years BP (right, both plots).

There are strong exponential regression fits $\left(\mathrm{R}^{2}=0.85, \mathrm{P}<0.01\right)$ for both sediment LAR and MAR from 100 to 40 years BP, indicating that sediment accumulation rates rapidly increased during this period. From 40 years BP to the present, there is another set of strong exponential regression fits $\left(\mathrm{R}^{2}=0.72, \mathrm{P}<0.01\right)$ for both sediment LAR and MAR, indicating that sediment accumulation rates rapidly decreased during this period. At 20 years BP the site was reclaimed as pasture, and MAR and LAR both increase due to reclamation disturbances to $0.55\left(\mathrm{~g} \mathrm{~cm}^{-2} \mathrm{yr}^{-1}\right)$ and $0.43\left(\mathrm{~cm} \mathrm{yr}^{-1}\right)$, respectively. After this, soils likely stabilized due to reclamation, and then sediment accumulation rates decreased to $0.48\left(\mathrm{~g} \mathrm{~cm}^{-2} \mathrm{yr}^{-1}\right)$ and $0.37\left(\mathrm{~cm} \mathrm{yr}^{-1}\right)$. The site was again disturbed 10 years $\mathrm{BP}$ using the FRA, and sediment accumulation rates increased again to $0.67\left(\mathrm{~g} \mathrm{~cm}^{-2} \mathrm{yr}^{-1}\right)$ and $0.51\left(\mathrm{~cm} \mathrm{yr}^{-1}\right)$. 
VFWB and BM_07 did not yield any useful ${ }^{210} \mathrm{~Pb}$ data. This is likely due to the relatively young age of these reclaimed mine sites (5, and 12 yrs., respectively). Analysis of the reclaimed mining site SFMC_15 (Figure 31) does not provide LAR data due to a lack of measured bulk density at the site. This trench provided evidence of increased MAR associated with the timing of the FRA. Sediment MARs for the site were determined to 82 years BP. At SFMC_15, a strong exponential regression fit $\left(\mathrm{R}^{2}=0.78\right.$, $\mathrm{P}<0.01$ ) shows that rates have increased rapidly over this period. At 18 years BP, the FRA was implemented when the MAR was $\sim 0.61\left(\mathrm{~g} \mathrm{~cm}^{-2} \mathrm{yr}^{-1}\right)$, and similar to MARs determined in push cores taken from site RFGC, there is a slight decrease in MAR from reclamation disturbance, followed by an increase to its maximum value at $1.12\left(\mathrm{~g} \mathrm{~cm}^{-2} \mathrm{yr}^{-}\right.$ $\left.{ }^{1}\right)$. Figure 32 compares the mean ${ }^{210} \mathrm{~Pb}$ ex MAR and LAR rates.

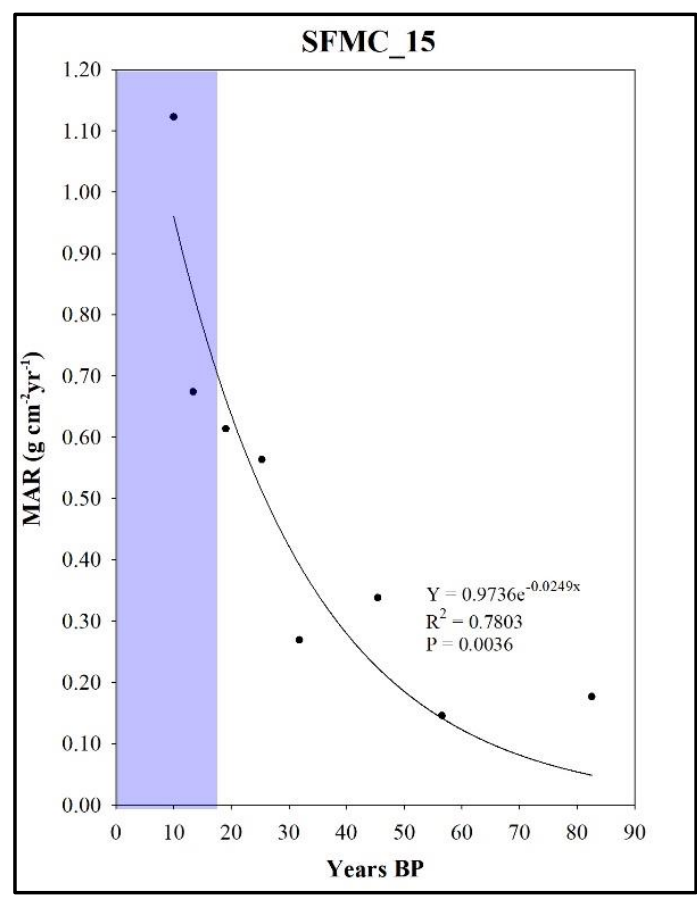

Figure 31. Sediment mass accumulation rate for trench SFMC_15. The shaded section of the graph provides the timing of the FRA (blue). 


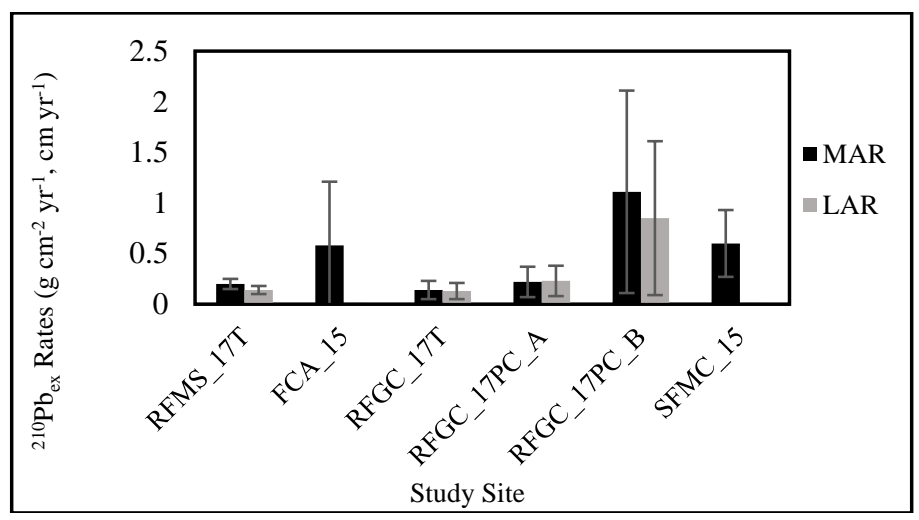

Figure 32. ${ }^{210} \mathrm{~Pb}_{\mathrm{ex}}$ MARs and LARs for study sites. Uncertainties reported at one standard deviation.

\subsection{Particulate Organic Carbon and Stable Isotopes}

\subsubsection{Particulate organic carbon and bulk density}

POC concentrations were determined for samples from all six trenches and the three push cores. Bulk density was calculated for all sampling sites with the exceptions of SFMC_15, FCA_15, and BM_07_16. All cores and trench data show, as expected, an inverse relationship between POC and bulk density, with bulk density increasing with depth while POC concentrations decrease. At all sites, POC is enriched at the surface (as expected). POC inventories over the top $10 \mathrm{~cm}$, and POC fluxes (determined using ${ }^{210} \mathrm{~Pb}$ ex-based rates) are listed in Table 6. Inventory and flux values are depicted in Figure 33. POC inventories are also compared with ${ }^{210} \mathrm{~Pb}$ ex based mass accumulation rates in Figure 34 . 
Table 6. POC inventories $(1-10 \mathrm{~cm})$, and surface $(0-2 \mathrm{~cm}$ for trenches; and mean value of 1-2 $\mathrm{cm}$ for push cores) POC fluxes for all cores and trenches. POC fluxes are calculated using mean ${ }^{210} \mathrm{~Pb}_{\text {ex }}$-derived sediment accumulation rates.

\begin{tabular}{|lcc|}
\multicolumn{1}{r}{ Trench/Core } & POC Inventories $\left(\mathrm{g} \mathrm{cm}^{-2}\right)$ & POC Flux $\left(\mathrm{g} \mathrm{cm}^{-2} \mathrm{y}^{-1}\right)$ \\
\hline RFMS_17T & 0.157 & 0.004 \\
\hline FCA_15 & 0.831 & 0.120 \\
\hline RFFB_18T & 0.032 & N.D. \\
\hline RFGC_17T & 0.204 & 0.003 \\
\hline RFGC_17PC_A & 0.251 & 0.018 \\
\hline RFGC_17PC_B & 0.772 & 0.203 \\
\hline VFWB_17PC_A & 0.229 & N.D. \\
\hline SFMC_15 & 0.369 & 0.019 \\
\hline BM_07_16 & 0.369 & N.D. \\
\hline
\end{tabular}
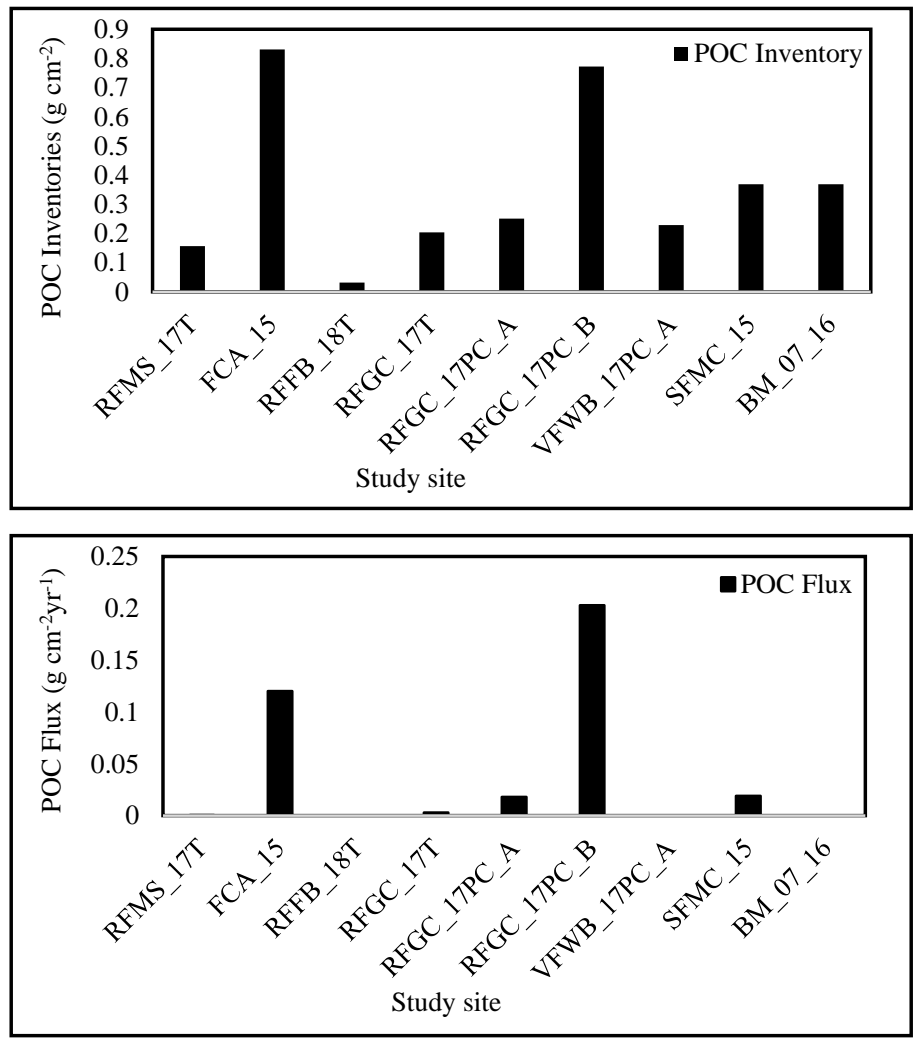

Figure 33. POC inventory $(1-10 \mathrm{~cm})$ (top), and POC flux (bottom) for all study sites. 


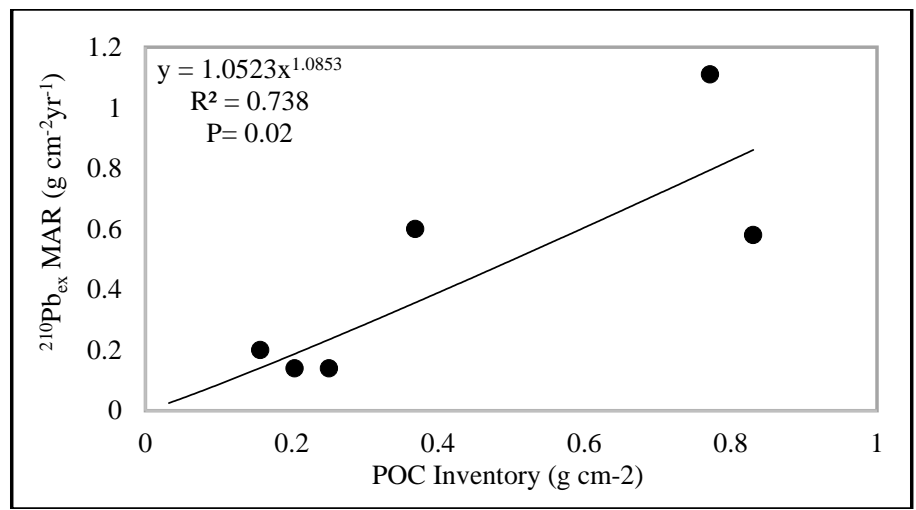

Figure 34. Comparison of ${ }^{210} \mathrm{~Pb}_{\text {ex }}$ mass accumulation rates and POC inventories for all sites.

The two control sites RFMS_17T and FCA_15 (Figure 35) both show similar trends in POC concentrations with depth. In both trenches, POC concentrations are highest near the surface and decreases with depth with the exception of concentrations at 14 and 32 cm for RFMS_17T, where there is a slight increase in POC. RFFB_18T and RFGC_17T (Figure 36) show similar trends as RFMS_17T. RFFB_18T shows small increases in POC concentrations at $8,14,16$, and $18 \mathrm{~cm}$. RFGC_17T shows a decrease in POC concentrations from 2-4 cm, after which an increase occurs at $6 \mathrm{~cm}$ for the highest value at $2.9 \%$. Values continually drop until $12 \mathrm{~cm}$, at which point they remain constant between $0.1-0.5 \%$ to the bottom of the trench. 

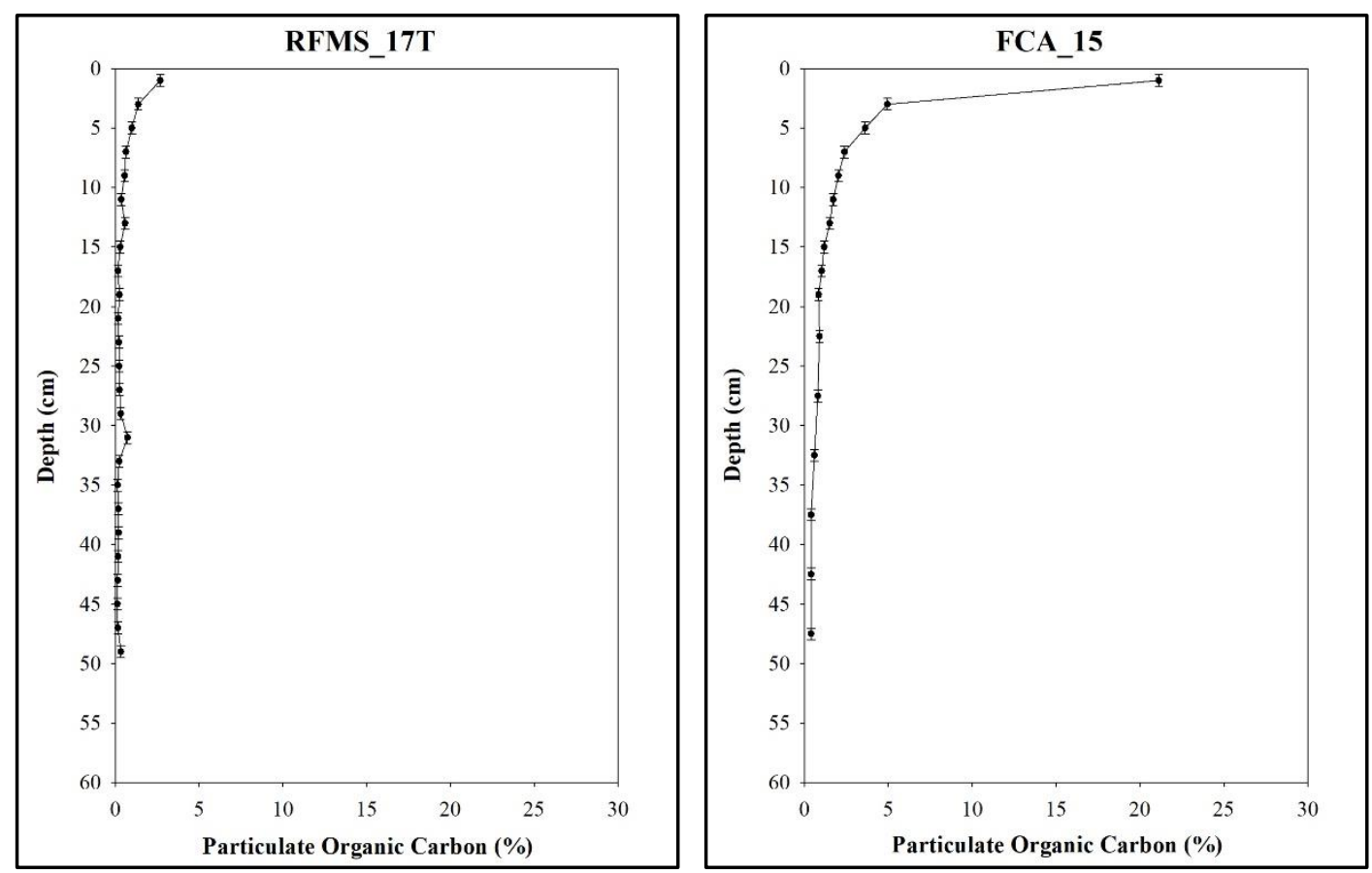

Figure 35. Particulate organic carbon (POC) concentration profiles for trenches RFMS_17T (left) and FCA_15 (right).
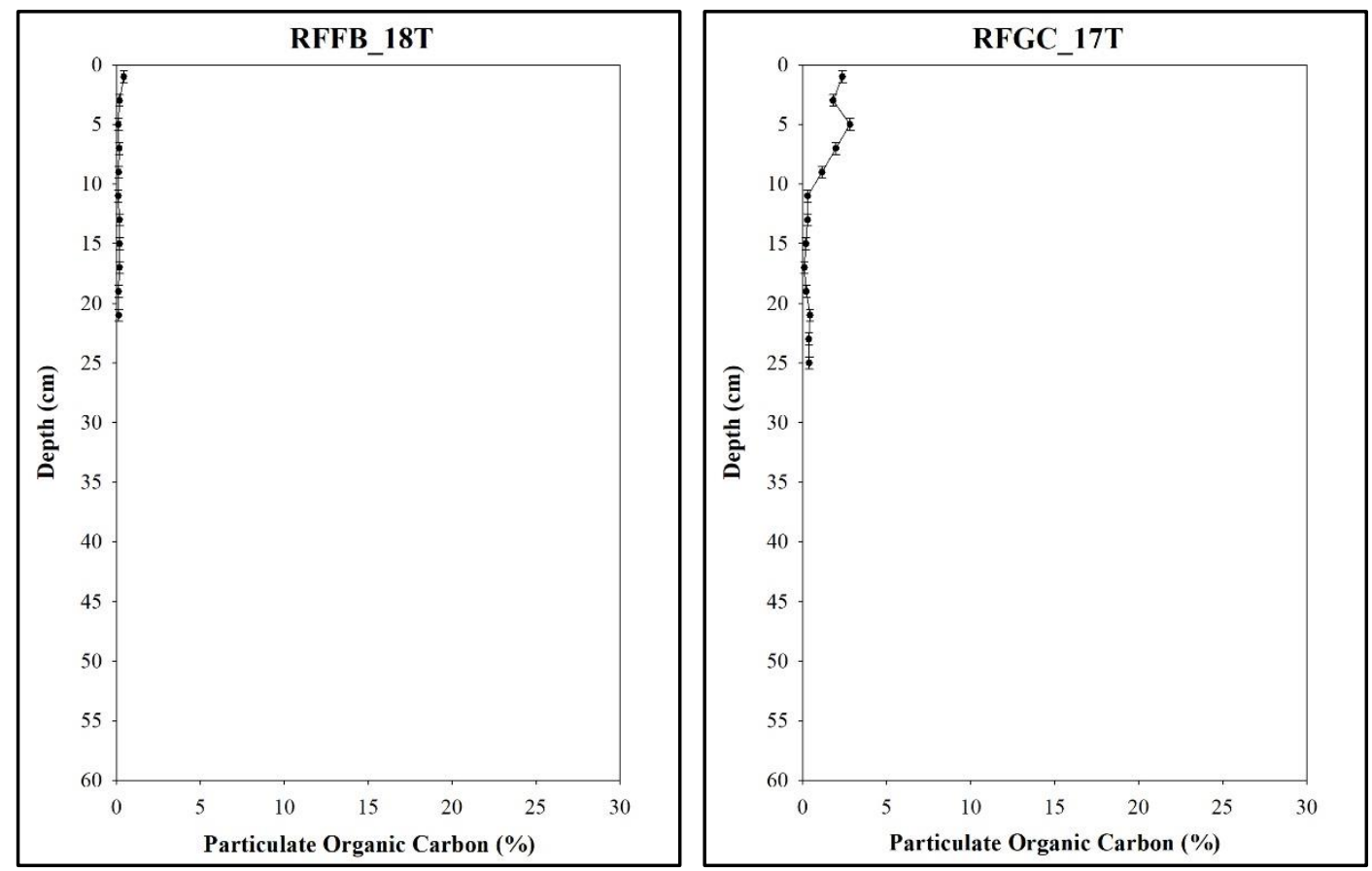

Figure 36. Particulate organic carbon (POC) concentration profiles for trenches RFFB_18T (left) and RFGC_17T (right). 
The two push cores RFGC_17PC_A and RFGC_17PC_B (Figure 37) show the same trends as the previous sites. RFGC_17PC_A and RFGC_17PC_B show almost identical POC concentration profiles. However, RFGC_17PC_B is shown to have much higher maximum POC concentrations.
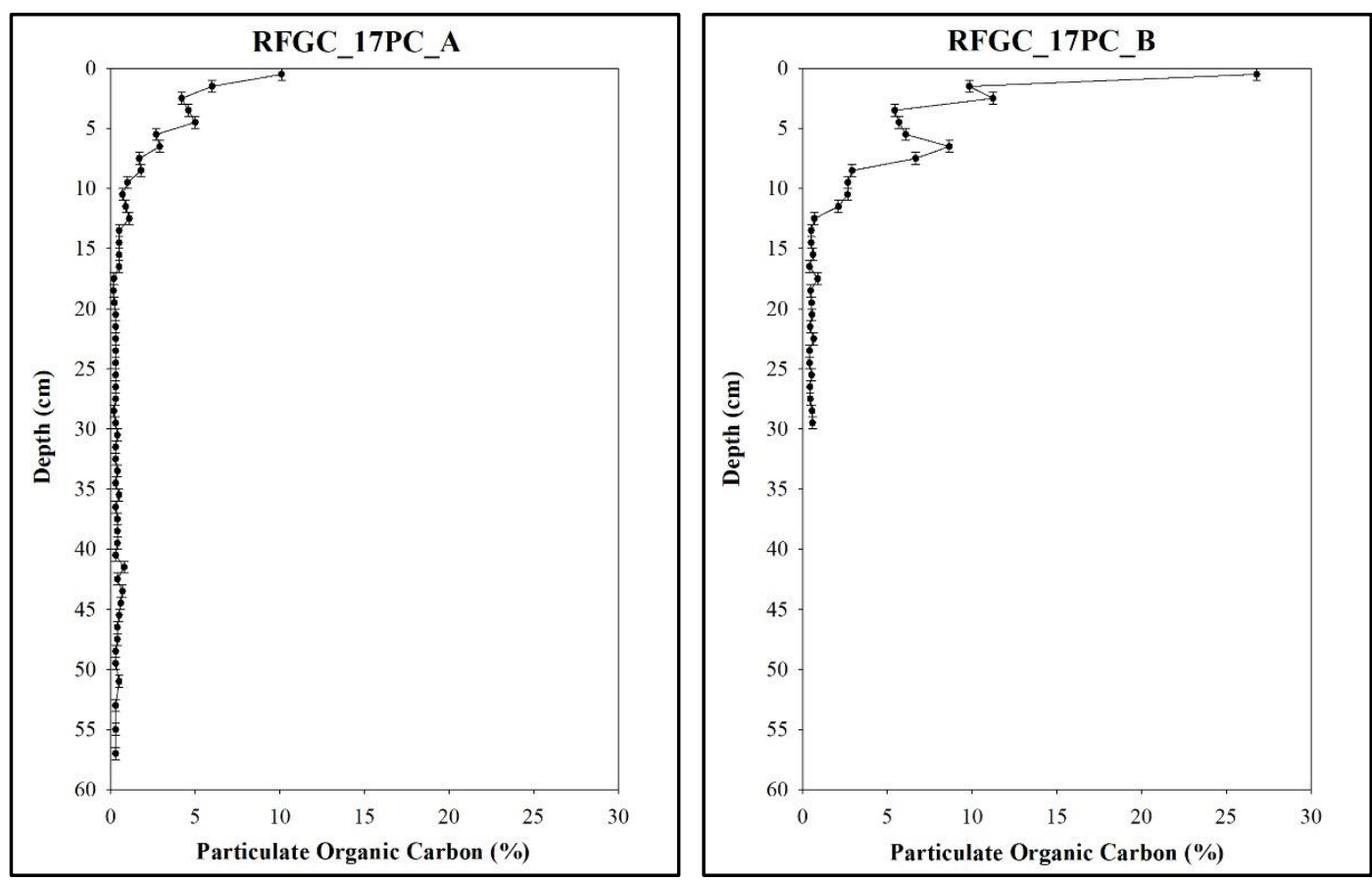

Figure 37. Particulate organic carbon (POC) concentration profiles for push core RFGC_17PC_A (left) and RFGC_17PC_B (right).

The trenches from the reclaimed mine lands at SFMC_15 and BM_07_16 are depicted in Figure 38. BM_07_16 follows the general trend seen for POC concentration profiles, with small spikes in POC concentrations at 18, 30, and $40 \mathrm{~cm}$. SFMC_15 shows fluctuations from 5 to $15 \mathrm{~cm}$ with a spike in values between 20 and $25 \mathrm{~cm}$. The final push core VFWB_17PC_A (Figure 39) shows the same trend as seen throughout the previous study sites. 

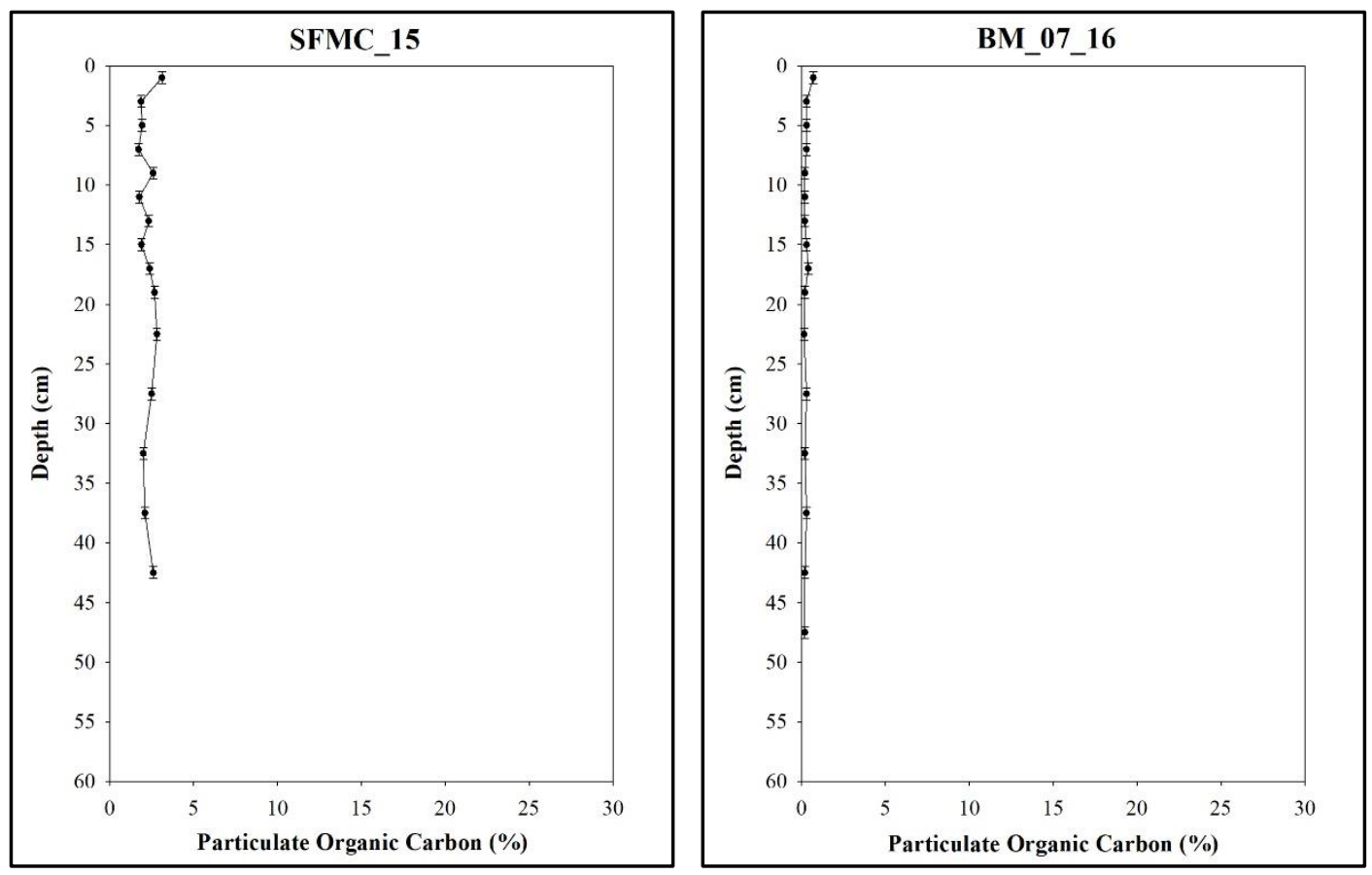

Figure 38. Particulate organic carbon (POC) concentration profiles for trenches SFMC_15 (left) and BM_07_16 (right).

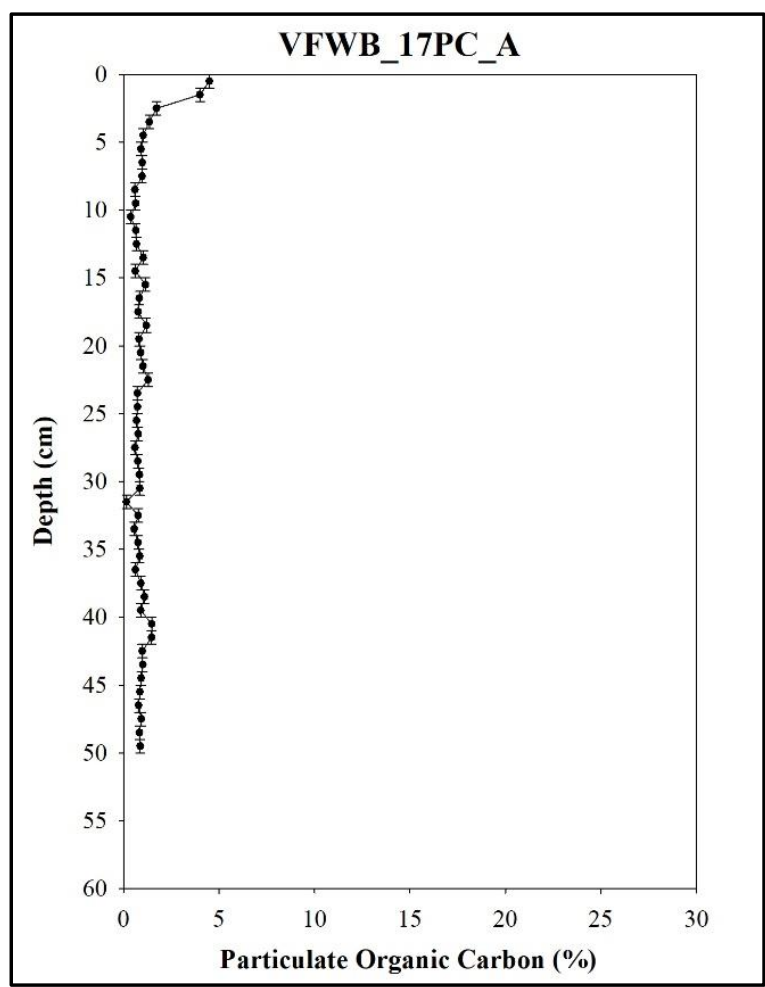

Figure 39. Particulate organic carbon (POC) concentration profile for push core VFWB_17PC_A. 


\subsubsection{Stable Carbon Isotopes}

Stable carbon isotope data were compiled for five trenches and the three push cores. Gaps in $\delta^{13} \mathrm{C}$ profiles are due to carbon isotope values that did not fall within acceptable detection limits. All $\delta^{13} \mathrm{C}$ profiles fall within values associated with forested landscapes (20\% to -35\%). Trenches RFMS_17T and FCA_15 are depicted in Figure 40. The values at RFMS_17T fall between $-25 \%$ to $-29 \%$. $\delta^{13} \mathrm{C}$ data for FCA_15 range from $-28 \%$ o to 26.1\%o, and show an enrichment in ${ }^{13} \mathrm{C}$ as depth increases.
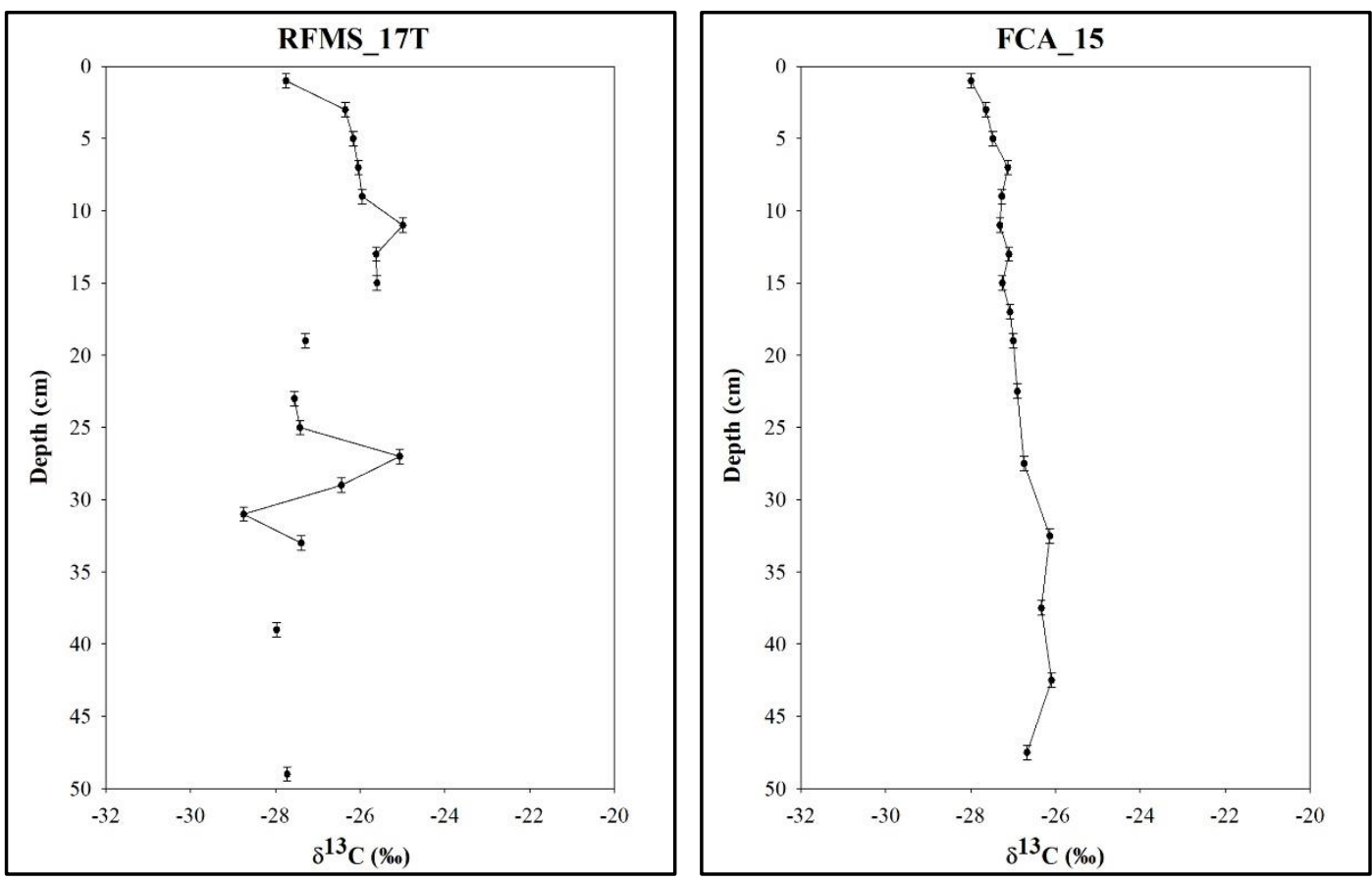

Figure 40. $\delta^{13} \mathrm{C}$ profiles for trenches RFMS_17T (left) and FCA_15 (right).

$\delta^{13} \mathrm{C}$ profiles for trench RFGC_17T and push core VFWB_17PC_A are depicted in

Figure $41 . \delta^{13} \mathrm{C}$ values for RFGC_17T range from $-26.8 \%$ to $-29 \%$. The values for VFWB_17PC_A range from -28\%o to $-25.5 \%$ with an overall enrichment in ${ }^{13} \mathrm{C}$ with increasing depth, with the exception of a depletion of ${ }^{13} \mathrm{C}$ at $23 \mathrm{~cm}$. The push cores RFGC_17PC_A and RFGC_17PC_B are depicted in Figure 42. RFGC_17PC_A exhibits 
enrichment in ${ }^{13} \mathrm{C}$ with depth. $\delta^{13} \mathrm{C}$ values range from $-31 \%$ to $-25.5 \%$. RFGC_17PC_B shows a depletion in ${ }^{13} \mathrm{C}$ as depth increases, with values ranging from $-25 \%$ to $-28 \%$.

BM_07_16 and SFMC_15 (Figure 43) both show a slight shift to more positive $\delta^{13} \mathrm{C}$ values as depth increases. SFMC_15 values range from $-26.9 \%$ to $-25.2 \%$ and shift to more positive values with increasing depth. BM_07_16 shows a slight enrichment with increased depth with values ranging from $-27.6 \%$ to $-25 \%$.
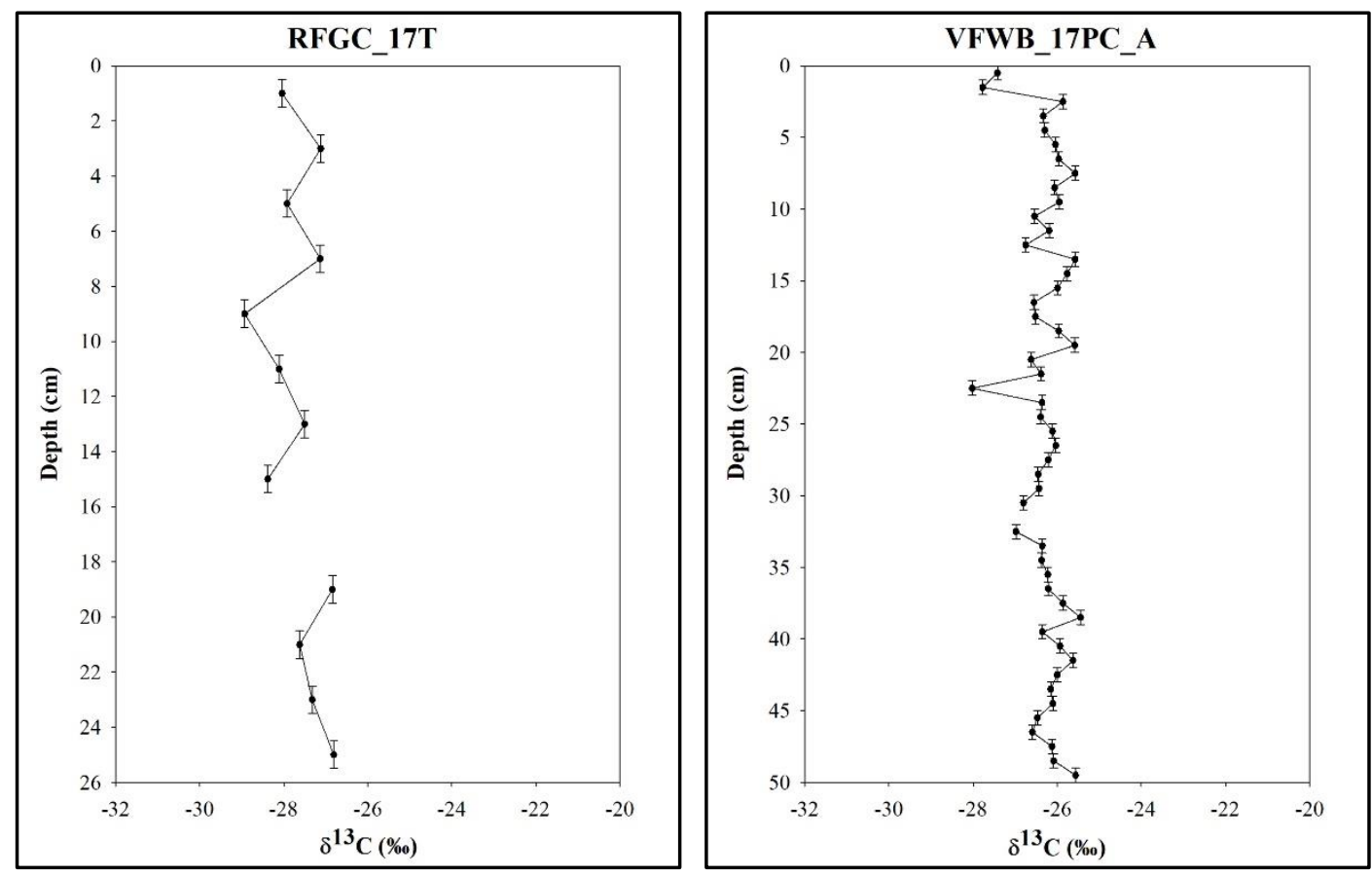

Figure $41 . \delta^{13} \mathrm{C}$ profiles for trench RFGC_17T (left) and push core VFWB_17PC_A (right). 

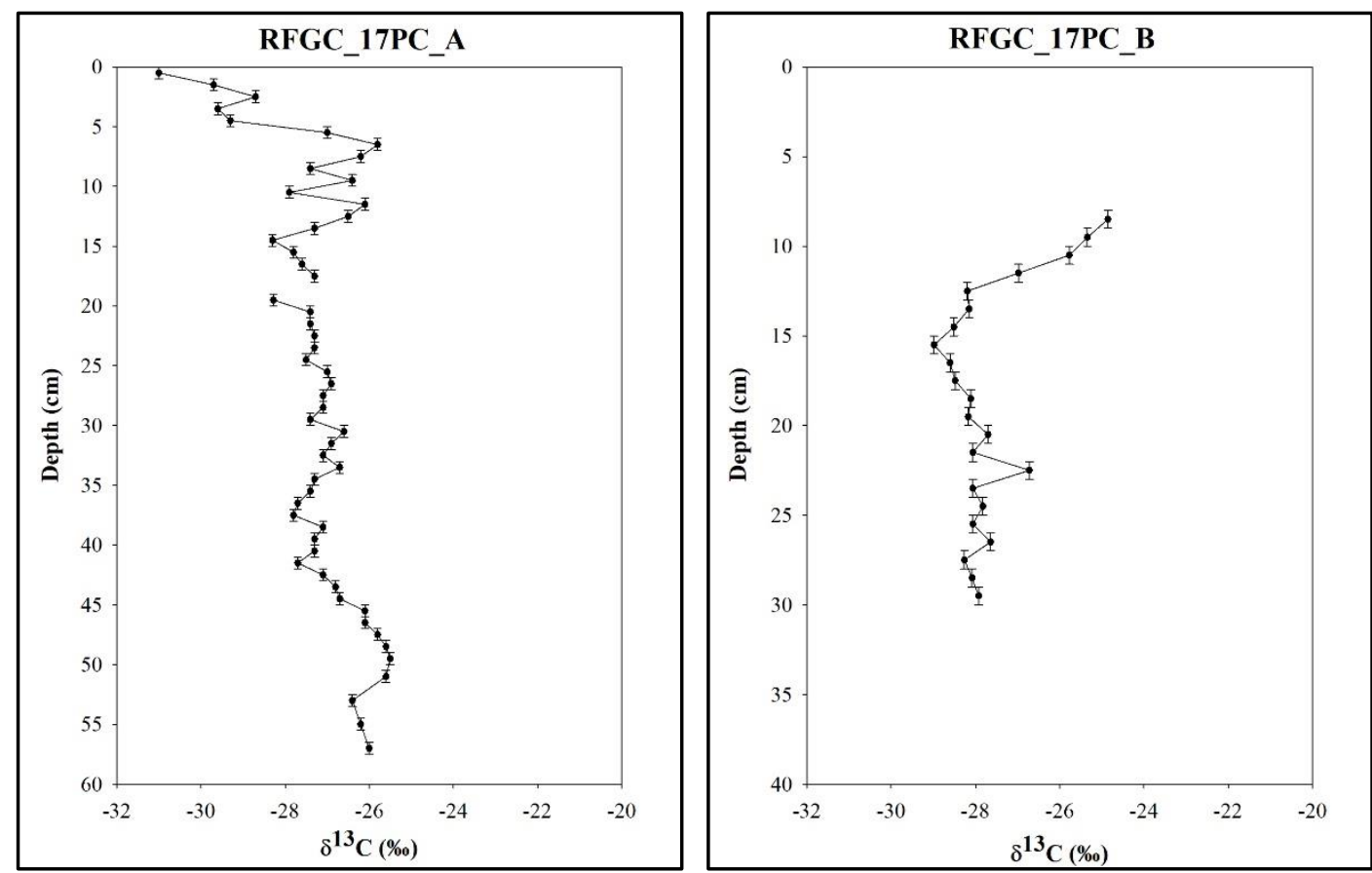

Figure $42 . \delta^{13} \mathrm{C}$ profiles for push cores RFGC_17PC_A (left) and RFGC_17PC_B (right).
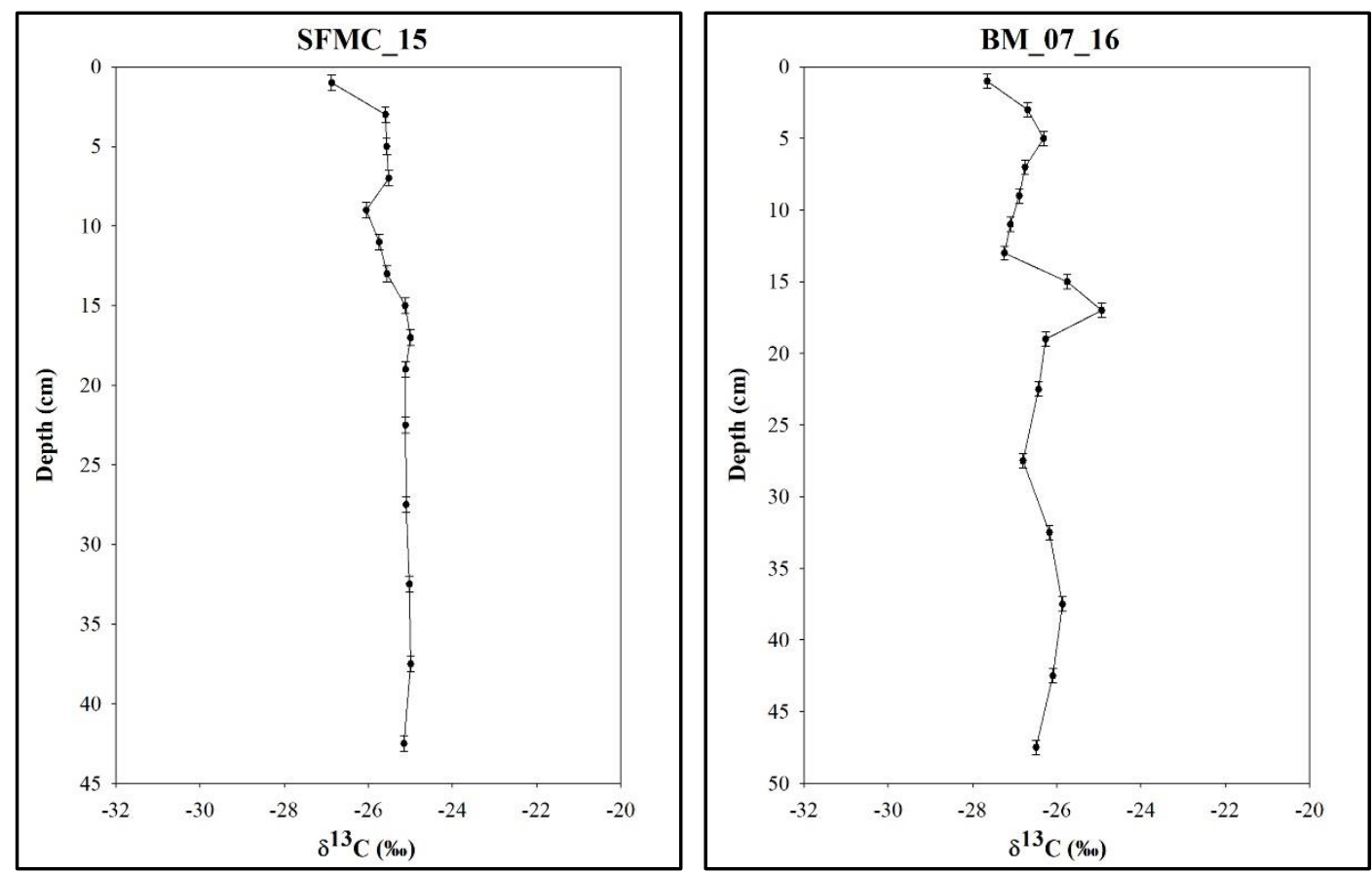

Figure 43. $\delta^{13}$ C profiles for trenches SFMC_15 (left) and BM_07_16 (right). 


\section{CHAPTER FOUR: DISCUSSION}

Little work has been done to measure sediment accumulation rates, and bulk changes in sedimentary organic matter $\delta^{13} \mathrm{C}$ in reclaimed mine lands and formerly logged areas. The findings of this study could potentially aid in the recovery of native hardwood forests that have been adversely impacted by the effects of strip mining and logging, in Kentucky and elsewhere. Results of this study are summarized by full core and trench profiles for all sites in Appendix E to aid in addressing the hypothesis.

RFFB_18T yielded the least amount of data for all study sites and only shows grain size and POC concentrations. As expected, the grain size profile in Figure 16 for this stream bank site shows that this site is dominated by sands, with appreciable gravel ( $20 \%$ throughout) and little variability in evidence over the section. The larger amount of gravel at the base of the trench ( 40\%) could indicate a change in the energy of the depositional system. The presence of more sand at this site is likely the reason that radionuclides are absent. However, the site is adjacent to a stream and sediments with radionuclides could have also been removed during scouring events from floods that occurred within the watershed in 2009. POC concentrations and inventory for this site (Figures 33, 36) are the lowest of all study sites. These low quantities of POC could also be an indicator of scouring at the study site. Logging ceased in this area over 36 years ago, but the site shows less organic carbon than the other two logging sites and the most recently reclaimed mining sites at VFWB and BM_07.

As expected, the control site at RFMS_17T shows that the site is dominated by sand size particles (Figure 15; 50\% over the whole section), with no erratic variations in particle size distribution within the fining upward sequence of the top $16 \mathrm{~cm}$. These 
results are similar to the grain size data at RFFB, which was also located adjacent to a small perennial stream. The changes in grain size from $20 \mathrm{~cm}$ to the end of the core may indicate an increase in the energy of the depositional environment. Due to this site's close proximity to a stream, this could be a result of flooding events in 2009 , since mining did not occur at this site. Radionuclide data (see below) suggests that sediments deeper than $\sim 20 \mathrm{~cm}$ likely represent the period during or immediately following active logging in this sub-basin, which is in congruence with the presence of appreciable gravel (20-40\%) and less silt between $20 \mathrm{~cm}$ and the end of the section. POC concentrations and inventory for the site (Figures 33, 35) do not show any irregularities, but there is less organic carbon at this site compared to the other control site at FCA (POC inventories are lower than FCA by more than a factor of 4). This is likely due to the location where sampling occurred (virtually no surface vegetation) and the potential for removal of organic matter from scouring events.

Neither ${ }^{137} \mathrm{Cs}$ (Figure 20) nor ${ }^{210} \mathrm{~Pb}$ ex are found below $15 \mathrm{~cm}$ in the section, suggesting that sediments below this depth represent $\sim 100$ years BP or more (during or immediately following active logging). The relatively strong linear regression fit for ${ }^{210} \mathrm{~Pb}$ ex sediment accumulation rates (Figure 26) show a gradual increase over the last century. These results were unexpected because logging within watersheds corresponds to increased magnitudes of sediment transport and deposition (Brown and Krygier 1971). Watersheds that have been logged show an increase in sedimentation by a factor of 0.6 to 5.0 (Megahan and Kidd 1972; Beschta 1978). This continuous increase in accumulation rates is likely not due to landslide activity in the area. Satellite imagery does not show any evidence of recent landslides (Figure 6). If landslides had occurred in the area, 
radionuclides would likely not be present due to deep burial of sediments. There were, however, multiple flooding events including a large event in 2009.

The increase in sedimentation could also be due to an overall increase in stream power. Both logged and undisturbed watersheds have shown increases in sedimentation with higher stream power (Rice et al. 1979). Periods with decreased streamflow could have been caused by large influxes of woody debris to streams from logging activity. Typically, undisturbed logged watersheds do not transport large amounts of woody debris (Benda 2005), so higher amounts of woody material could create dams that slow stream flow. The ${ }^{137}$ Cs-based sediment accumulation rates from 1952 are a bit higher than the average ${ }^{210} \mathrm{~Pb}$ ex accumulation rates (Tables 3 and 5), but compare reasonably well. Both radionuclides do indicate that over the last century the site has shown net deposition (Tables 2 and 4).

The trench grain size profile at the second control site FCA_15 (Figure 15) shows a coarsening upwards sequence from $\sim 20 \mathrm{~cm}$ to the surface (increasing gravel and decreasing silt) with no erratic changes in particle size distribution over the section. This does not appear to be out of the ordinary due to the site's location at a ridgetop. In this setting, very fine-grained sediments are either not deposited, or can be winnowed by wind and rain, or localized events (Foufoula-Georgiou et al. 2010). The upper $10 \mathrm{~cm}$ of this site are dominated by gravel likely from colluvium, with the rest dominated by siltsized particles (20-40\%) with some sand (5-30\%) and minor clay (5-10\%). The POC concentrations, inventory and flux for this site are all much higher than the other two logged sites in the study (Figure 35), unsurprisingly. This is very likely due to the site's location on a forested ridgetop, where both trees and ground cover vegetation are 
relatively abundant; and its distance from any streams that could periodically remove organic-rich sediments.

${ }^{137} \mathrm{Cs}$ extends to $19 \mathrm{~cm}$ (Figure 21 ) and ${ }^{210} \mathrm{~Pb}$ ex to $27 \mathrm{~cm}$ in the section, suggesting that sediments below this depth $(27 \mathrm{~cm})$ represent more than 100 years $\mathrm{BP}$, and so one or both of these radionuclides record the period during which this area was logged. ${ }^{210} \mathrm{~Pb}_{\mathrm{ex}}$ based sediment accumulation rates from $\sim 120-70$ years BP are erratic (Figure 27), but capture the highest resolved sediment accumulation rate $\left(\sim 2.49 \mathrm{~g} \mathrm{~cm}^{-2} \mathrm{y}^{-1}\right)$ of any site, at $\sim 100$ years BP, when this area was actively logged. A strong exponential regression fit for ${ }^{210} \mathrm{~Pb}_{\mathrm{ex}}$ (Figure 27 ) shows that rates sharply declined from $60 \mathrm{BP}$ to the present. This is likely due to the regrowth of forests in the area. Both radionuclides indicate that the site has been net depositional over the period of record (Tables 2 and 4$)$. The average ${ }^{210} \mathrm{~Pb}_{\mathrm{ex}}-$ based and ${ }^{137} \mathrm{Cs}$-based sediment mass accumulation rates are very similar (Tables 3 and 5).

Results for RFGC_17T grain size (Figure 16) shows a fining upward sequence from $\sim 12 \mathrm{~cm}$ to the surface, without any erratic changes to particle size distribution over the section. The upper $10 \mathrm{~cm}$ is dominated by silts (50-70\%), with the lower section of the trench dominated by sands $(\sim 60 \%)$. The high amount of silt in the upper part of this trench is not unexpected, as the site is located in the floodplain of a small stream. The sandier sediments lower in the profile were likely deposited during periods of elevated mining activity that would have led to elevated sediment loading and deposition. The presence of these coarser sediments could also indicate an increase in the energy of the environment, which would explain why this site is shown as net erosional. POC concentrations, inventory and flux for this site follows the same general trend seen at all 
other sampling sites, but shows less organic carbon than the two cores collected at this site (Figure 36).

The erratic and truncated nature of the ${ }^{137} \mathrm{Cs}$ profile is unsurprising, given the shallow depth of this trench $(26 \mathrm{~cm}) .{ }^{210} \mathrm{~Pb}$ ex penetrates to $\sim 11 \mathrm{~cm}$, resolving $\sim 50$ years of record. A strong exponential regression fit to ${ }^{210} \mathrm{~Pb}_{\mathrm{ex}}$-based sediment accumulation rates indicates a rapid increase in rates over this period (Figure 28). This should be expected due to mining activity. Although the site was reclaimed as pasture 20 year ago (1997), in 1998 there was still a large amount (64\%) of land scarring within the watershed due to mining activity (Figure 7). This exposed sediment would still be unstable and lead to increased sediment loading at the study site. The ${ }^{210} \mathrm{~Pb}_{\text {ex }}$ sedimentation ratio indicates the site has been net erosional over the period of record (Table 4), which is expected given the shallow penetration depth and reduced temporal range resolved using this isotope. After the site was disturbed and reclaimed using the FRA (2007), accumulation rates continued to increase, but does not necessarily support the hypothesis due to a lack of captured time.

The two push cores collected from Guy Cove, RFGC_17PC_A and RFGC_17PC_B, show many similarities to one another, as expected. Both grain size profiles (Figure 17) exhibit fining upward sequences from $\sim 20 \mathrm{~cm}$ to the surface. This same trend (from $\sim 12$ $\mathrm{cm}$ to the surface) is seen within the trench collected from this site. In both cores, the sections below $20 \mathrm{~cm}$ are dominated by sands (50-80\%), with appreciable gravel appearing below $70 \mathrm{~cm}$ in core A (up to $\sim 20 \%$ ). These coarser sediments could reflect a higher energy setting and a different, and dominantly coarser, supply of sediment than in recent time, both certainly due to mining here. Another explanation for the courser 
sediments is that it represents and older stream bed that was buried. POC concentrations, inventories and fluxes for both sites show the same trends, but RFGC_17PC_B shows the highest POC flux, and second highest POC inventory (after control site FCA) of all stations (Figure 37). The differences observed between the two cores and one trench sampled at this site reflect heterogeneities over small spatial scales.

The ${ }^{137}$ Cs-based sediment accumulation rates for RFGC_17PC_A and RFGC_17PC_B are similar to one another, as expected. Both cores show that rates decreased from 1952 to 1963 (Table 3). Strong exponential regression fits to ${ }^{210} \mathrm{~Pb}_{\mathrm{ex}}$ derived sediment accumulation rates from RFGC_17PC_B (Figure 30) show that accumulation rates rapidly increased from $\sim 100$ years to $\sim 40$ years $\mathrm{BP}$, and then rapidly decreased from $\sim 40$ years BP to the present, with some fluctuations over the last $\sim 30$ years BP. These large changes are not evident at RFGC_17PC_A (Figure 29), but this is likely be due to a less robust ${ }^{210} \mathrm{~Pb}$ ex profile for this core.

This large spike in accumulation rates at RFGC_17PC_B occurred before mining began around this site in the late 1980s. The increase in accumulation rates around 30 years BP are likely from the strip mining that occurred within the watershed, there should have been a large increase in sediment loading around this site due to the large amount of mine spoil produced (Ramani 2012). This should show that the site has been net depositional, which is supported by both ${ }^{137} \mathrm{Cs}$ and ${ }^{210} \mathrm{~Pb}$ ex sedimentation ratios (Tables 2 and 4). The site was reclaimed using grassland reclamation 20 years BP, and was then redisturbed 10 years later to implement the FRA. After implementation of the FRA, accumulation rates in both cores increased, which supports the hypothesis. The results 
from the trench and two cores from RFGC not only support the hypothesis, but also contain the most robust record of what occurred at any of the study sites.

The grain size distribution for trench SFMC_15 (Figure 18) shows that this is the only site dominated by gravel sized particles over the entire section, with the highest value at $90 \%$, and average value at $\sim 60 \%$. This is to be expected due to mining activity that occurred 18 years ago at this site and the disturbance of bedrock from strip mining (Haering et al. 2004; Jaeger 2015) and the reconstruction of the site using large amounts of mine spoil. The POC concentration profile for this area does not show any major irregularities (Figure 38). POC inventories and fluxes are similar to the other mined sites (Figure 33, Table 6).

There was no detectable ${ }^{137} \mathrm{Cs}$ present at this site. ${ }^{210} \mathrm{~Pb}_{\text {ex }}$-based sediment accumulation rates (Figure 31) over time have increased exponentially at this site over the period of record ( 80 years), with the highest values seen after the FRA was implemented 18 years BP, which supports the hypothesis. Values prior to 30 years BP may be inaccurate due to how the site is constructed. The thick layers of mine spoil used to reconstruct the site would have covered radionuclides present before the site was reclaimed. The rapid rise in sediment accumulation rates over the period of record is not likely attributable to mining activity in this area, but the presence of vegetation on the site. As these plants grow their root systems will continually break down the thick layers of mine spoil present. The ${ }^{210} \mathrm{~Pb}_{\text {ex }}$ sedimentation ratio indicates that the site has been net erosional over the period of record (Table 4), which is likely due to a combination of some episodic erosion and the coarse-grained nature of the sediments here, which are poor adsorption surfaces for ${ }^{210} \mathrm{~Pb}$. 
The grain size profile for BM_07_16 (Figure 18) shows high quantities of sands and gravels, with moderate amounts of silt ( 20-30\%) and little clay ( $5 \%)$. The POC concentration profile does not show an irregular trend, but shows the lowest POC concentrations of all the reclaimed mining sites (Figure 38). POC inventories are similar to the other previously mined sites (except for RFGC_17PC _B, which was much higher), and POC fluxes could not be determined for this site. There was no ${ }^{137} \mathrm{Cs}$ present at BM_07_16 and there was also insufficient ${ }^{210} \mathrm{~Pb}$ ex to determine sediment accumulation rates, both likely due to the prevalence of sand and gravel and the young age of the reclaimed site (12 yr.).

The grain size distribution for VFWB_17PC_A (Figure 19) is dominated by silts and sands, and appears fairly consistent over the entire section. Gravels are present throughout much of the section, comprising as much as $20 \%$ in places, with lesser amounts of clay-sized particles $(\sim \leq 10 \%)$. These results should be expected due to the very young age (5 years) of this reclaimed mining site. This explains the lack of ${ }^{137} \mathrm{Cs}$, and very limited ${ }^{210} \mathrm{~Pb}_{\text {ex }}$ data. Any sediments deposited here prior to mining were likely either eroded, or deeply buried during mining due to subsequent valley fill operations with sediments lacking either of these radionuclides. POC concentration data for this site follows the normal trend seen with other sites but is slightly irregular at the surface (Figure 39). The site is a wetland and should show higher amounts of organic carbon similar to what is seen at RFGC.

The grain size and radionuclide data from this study are valuable tools for understanding the complex erosion, sediment transport and depositional processes following coal mine reclamation in eastern Kentucky and other parts of the world. The 
results for RFGC are a good indicator of increased sediment loading due to valley fill operations, as seen by the increase and decrease in accumulation rates 0 to 40 years BP. The results showing a large spike in sediment accumulation is typical of areas that have valley fills from previous strip mining (Bovis et al. 1998; Bernhardt and Palmer 2011). If reclamation techniques based on the FRA are widely implemented, both ridgetop and watersheds within mine lands could show increases in sediment loading and transport.

The ${ }^{7} \mathrm{Be}$ data present in this study could be a potential tool for observing short term bioturbation (Sharma et al. 1987) at reclaimed mines and logged watersheds. ${ }^{7} \mathrm{Be}$ is only present at older sites (RFMS, FCA, RFGC_17T, and SFMC) with the exception of the stream site RFFB. The lack of ${ }^{7} \mathrm{Be}$ at RFFB should be expected due to no other radio nuclides being present at the site and low POC concentrations and inventories. The presence of ${ }^{7} \mathrm{Be}$ at the older sites could indicate that bioturbation is occurring which would be beneficial in soil development. At this time, it is difficult to infer the effects of bioturbation because there is no data pertaining to invertebrate organisms in the sampled sediment. Another possible explanation for ${ }^{7} \mathrm{Be}$ present at these sites could be from short term surface erosion (Yang et al. 2006).

POC concentration profiles represented by figures 35-39 show that all sites follow the typical and expected trends, with the largest amount of POC near the surface, where it is sourced from decaying plant matter. Organic carbon typically decreases with depth (Jobbágy and Jackson 2000). A site by site comparison of POC (1-10 cm) inventories and fluxes (Figure 33) appears to show that reclaimed mine lands tend to have higher POC inventories and lower fluxes than reclaimed logging sites. However, comparing the mean values of POC inventories and fluxes between the two populations (logged vs. mined) 
yields values for both that are not different when considering their uncertainties. These results were unexpected due to the different site histories. It was believed that the POC inventories and fluxes of mined sites would be much lower than previously logged sites. Naturally regenerated logging sites in this study have had more recovery time than all mined sites and would likely have more organic carbon. Mined areas such as SFMC and BM_07 would likely have had a large portion of the topsoil damaged or completely removed (Mensah 2015) and should have showed low amounts of organic carbon in the top $10 \mathrm{~cm}$. Figure 34 plots the relationship between mean ${ }^{210} \mathrm{~Pb}_{\text {ex }}$ mass accumulation rates and POC inventories for all sites. There is a strong relationship $\left(\mathrm{R}^{2}=0.74, \mathrm{P}=0.02\right)$ indicating that as MARs increase more POC is delivered to the site.

Figures 40-43 show that all sites have no stable isotope values to indicate a transition from $\mathrm{C} 3$ to $\mathrm{C} 4$ to $\mathrm{C} 3$ plants, all values are within the ranges of forested lands. Reclaimed mine lands, however, show that $\delta^{13} \mathrm{C}$ becomes more depleted over time. Reclaimed mines show values ranging from $-22 \%$ to $-27 \%$ in sites that range from 0 to 80 years old (Maharaj et al. 2007). Stable isotope values for all sites did not show enrichments near $22 \%$. There may not have been an adequate amount of organic matter or too much time had passed to show a transition from grasses (C4) to trees (C3). Another possible explanation for this lack of transition could be caused the respiration of $\mathrm{CO}_{2}$ from decaying organic matter. $\mathrm{CO}_{2}$ from decomposition is shown to be depleted in Carbon-13 (Wynn et al. 2006) implying that Carbon-12 is removed from the soil with the gas. The steady removal of Carbon-12 from organic decomposition would likely prevent stable isotope values from reflecting the actual source of the organic material. 


\section{CHAPTER FIVE: CONCLUSIONS}

The results of this study successfully addressed the hypothesis. Sites that have been reclaimed from mining have yielded adequate data to form a conclusion. There is insufficient evidence to link changes in sediment accumulation rates with the size of site sub-basins, or the areas of these sub-basins that were mined since the 1990's. VFWB and BM_07 do not contain enough ${ }^{210} \mathrm{~Pb}$ ex data to provide adequate sediment accumulation rates up to the timing of reclamation. This study concludes that the FRA does show increased sediment accumulation rates compared to grassland reclamation in reclaimed mine lands and leads to increased accumulation rates in mine lands that were not previously reclaimed as pasture.

These findings show that areas reclaimed with the FRA would see an increase in sediment transport, loading, and erosion. While the FRA shows increases in the previously listed sedimentary processes, they are likely not severe enough to be detrimental to the recovery of these disturbed sites. A major benefit from the FRA could be seen with the restoration of forest soils. The strong relationship between ${ }^{210} \mathrm{~Pb}_{\text {ex }}$ MARs and POC inventories show that even in sites with extensive strip mining and topsoil loss (SFMC, BM_07), increased accumulation rates are delivering organic carbon to the upper $10 \mathrm{~cm}$ of soil.

The results of this study agree with the finding of previous work on sediment transport and loading within reclaimed mine watersheds, but future work is needed to study the effects of the FRA. Future studies should include an in-depth look at sedimentation ponds constructed to trap eroded sediment within watersheds. These ponds will likely show a more accurate representation of sediment transport and loading. The 
results of ${ }^{7} \mathrm{Be}$ show that in the future, invertebrate organisms should be taken into account when sampling to help determine if short term surface mixing is due to bioturbation or erosional processes. More logged sites are needed to provide a clearer picture of the recovery time and changes in sediment transport before and after reclamation. Overall, the objectives of this study were completed, and the hypothesis is supported by the radionuclide accumulation rates. 


\section{APPENDICES}

Appendix A. Study Site Coordinates, Core Shortening, Calculated Mining Activity, and Sediment Physical Properties

\begin{tabular}{|c|c|c|}
\hline \multicolumn{2}{|c|}{ Table A1. Study Site Coordinates } \\
\hline Study Site & Latitude & Longitude \\
\hline RFMS & 37.47425 & -83.15474 \\
\hline RFFB & 37.47160 & -83.15600 \\
\hline FCA & 37.46400 & -83.14100 \\
\hline RFGC & 37.41930 & -83.17088 \\
\hline VFWB & 37.38360 & -83.15010 \\
\hline SFMC & 37.41151 & -83.12571 \\
\hline BM_07 & 37.60211 & -82.41103 \\
\hline
\end{tabular}

\begin{tabular}{|c|c|c|c|}
\hline \multicolumn{4}{|c|}{ Table A2. Core Shortening } \\
\hline Study Site & Inner Core $(\mathrm{cm})$ & Outer Core $(\mathrm{cm})$ & Core Shortening $(\mathrm{cm})$ \\
\hline RFGC_17PC_A & 55.5 & 36.0 & 19.5 \\
\hline RFGC_17PC_B & 53.5 & 34.0 & 19.5 \\
\hline VFWB & N.D. & N.D. & N.D. \\
\hline
\end{tabular}

\begin{tabular}{|c|c|c|c|c|}
\hline \multicolumn{5}{|c|}{ Table A3. Sub Basin Mining Extent 1994-2008 } \\
\hline Sub Basin & $\begin{array}{c}\text { Mined Area } \\
1994\left(\mathrm{~km}^{2}\right)\end{array}$ & $\begin{array}{c}\text { Mined Area } \\
1998\left(\mathrm{~km}^{2}\right)\end{array}$ & $\begin{array}{c}\text { Mined Area } \\
2008\left(\mathrm{~km}^{2}\right)\end{array}$ & $\begin{array}{c}\text { Mined Area } \\
2016\left(\mathrm{~km}^{2}\right)\end{array}$ \\
\hline Laurel Fork & 4.28 & 4.21 & 0.00 & 0.00 \\
\hline Long Fork & 1.10 & 3.34 & 3.13 & 4.34 \\
\hline $\begin{array}{c}\text { Troublesome } \\
\text { Creek }\end{array}$ & 0.00 & 0.11 & 2.51 & 0.88 \\
\hline
\end{tabular}




\begin{tabular}{|c|c|c|c|c|}
\hline \multicolumn{5}{|c|}{ Table A3. Continued } \\
\hline Brush Fork & 1.92 & 1.22 & 3.79 & 1.74 \\
\hline
\end{tabular}

\begin{tabular}{|c|c|c|}
\hline \multicolumn{3}{|c|}{ Table A4. Areal Extent of Mining } \\
\hline Sub Basin & Basin Area $\left(\mathrm{km}^{2}\right)$ & Maximum Areal Extent of Mining (\%) \\
\hline Clemons Fork & 4.20 & 0 \\
\hline Coles Fork & 17.20 & 0 \\
\hline Laurel Fork & 6.56 & 65 \\
\hline Long Fork & 10.80 & 40 \\
\hline Troublesome Creek & 8.17 & 31 \\
\hline Brush Fork & 28.40 & 13 \\
\hline
\end{tabular}

\begin{tabular}{|c|c|c|c|c|c|c|c|}
\hline \multicolumn{7}{|c|}{ Table A5. RFMS_17T Sediment Physical Properties } \\
\hline $\begin{array}{c}\text { Sample } \\
\text { Interval } \\
(\mathrm{cm})\end{array}$ & $\begin{array}{c}\text { Organic } \\
\text { Carbon } \\
(\%)\end{array}$ & $\begin{array}{c}\text { Bulk density } \\
\left(\mathrm{g} / \mathrm{cm}^{3}\right)\end{array}$ & $\begin{array}{c}\text { Cumulative } \\
\text { Mass depth } \\
\left(\mathrm{g} / \mathrm{cm}^{2}\right)\end{array}$ & $\begin{array}{c}\text { Gravel } \\
(\%)\end{array}$ & $\begin{array}{c}\text { Sand } \\
(\%)\end{array}$ & $\begin{array}{c}\text { Silt } \\
(\%)\end{array}$ & $\begin{array}{c}\text { Clay } \\
(\%)\end{array}$ \\
\hline $0-2$ & 2.68 & 0.58 & $2.46 \pm 0.25$ & 0.87 & 49.22 & 46.14 & 3.77 \\
\hline $2-4$ & 1.37 & 0.61 & $5.04 \pm 0.50$ & 1.09 & 43.20 & 45.59 & 10.11 \\
\hline $4-6$ & 0.98 & 0.63 & $7.57 \pm 0.76$ & 4.06 & 52.07 & 38.47 & 5.40 \\
\hline $6-8$ & 0.63 & 0.63 & $10.09 \pm 1.01$ & 4.79 & 53.81 & 36.68 & 4.73 \\
\hline $8-10$ & 0.55 & 0.71 & $12.85 \pm 1.29$ & 4.36 & 54.48 & 35.53 & 5.63 \\
\hline $10-12$ & 0.35 & 0.73 & $15.84 \pm 1.58$ & 5.76 & 54.19 & 34.70 & 5.35 \\
\hline $12-14$ & 0.58 & 0.81 & $19.47 \pm 1.95$ & 6.55 & 58.20 & 30.51 & 4.74 \\
\hline $14-16$ & 0.29 & 0.82 & $23.09 \pm 2.31$ & 2.69 & 56.36 & 36.20 & 4.75 \\
\hline $16-18$ & 0.15 & 0.75 & $27.02 \pm 2.70$ & 4.21 & 68.74 & 23.58 & 3.47 \\
\hline $18-20$ & 0.25 & 0.71 & $30.98 \pm 3.10$ & 1.76 & 68.13 & 26.26 & 3.84 \\
\hline $20-22$ & 0.17 & 0.78 & $34.82 \pm 3.48$ & 15.54 & 60.55 & 21.03 & 2.89 \\
\hline $22-24$ & 0.21 & 0.73 & $38.80 \pm 3.88$ & 6.22 & 63.01 & 26.60 & 4.16 \\
\hline $24-26$ & 0.22 & 0.78 & $42.58 \pm 4.26$ & 11.75 & 58.83 & 25.42 & 4.01 \\
\hline $26-28$ & 0.25 & 0.82 & $46.4 \pm 4.64$ & 20.32 & 54.23 & 22.50 & 2.95 \\
\hline $28-30$ & 0.32 & 0.77 & $50.71 \pm 5.07$ & 8.35 & 59.66 & 28.48 & 3.51 \\
\hline $30-32$ & 0.73 & 0.75 & $55.10 \pm 5.51$ & 3.74 & 63.46 & 28.99 & 3.81 \\
\hline $32-34$ & 0.23 & 0.81 & $59.47 \pm 5.95$ & 16.14 & 59.13 & 21.94 & 2.80 \\
\hline $34-36$ & 0.13 & 0.86 & $63.56 \pm 6.36$ & 33.21 & 43.80 & 20.30 & 2.69 \\
\hline $36-38$ & 0.18 & 0.82 & $67.73 \pm 6.77$ & 17.80 & 51.32 & 27.49 & 3.39 \\
\hline $38-40$ & 0.20 & 0.83 & $72.01 \pm 7.20$ & 22.29 & 51.09 & 23.62 & 2.99 \\
\hline $40-42$ & 0.16 & 0.77 & $76.29 \pm 7.63$ & 20.17 & 54.22 & 22.65 & 2.95 \\
\hline $42-44$ & 0.14 & 0.85 & $80.25 \pm 8.03$ & 13.66 & 46.92 & 35.10 & 4.32 \\
\hline $44-46$ & 0.12 & 0.78 & $83.97 \pm 8.40$ & 18.53 & 45.75 & 31.47 & 4.25 \\
\hline
\end{tabular}




\begin{tabular}{|l|l|l|l|c|c|c|c|}
\hline \multicolumn{8}{|c|}{ Table A5. Continued } \\
\hline $46-48$ & 0.15 & 0.76 & $87.99 \pm 8.80$ & 7.14 & 48.79 & 38.88 & 5.18 \\
\hline $48-50$ & 0.33 & 0.87 & $91.72 \pm 9.17$ & 17.35 & 45.94 & 32.98 & 3.73 \\
\hline
\end{tabular}

\begin{tabular}{|c|c|c|c|c|c|c|c|}
\hline \multicolumn{7}{|c|}{ Table A6. FCA_15 Sediment Physical Properties } \\
\hline $\begin{array}{c}\text { Sample } \\
\text { Interval } \\
(\mathrm{cm})\end{array}$ & $\begin{array}{c}\text { Organic } \\
\text { Carbon } \\
(\%)\end{array}$ & $\begin{array}{c}\text { Bulk density } \\
\left(\mathrm{g} / \mathrm{cm}^{3}\right)\end{array}$ & $\begin{array}{c}\text { Cumulative } \\
\text { Mass depth } \\
\left(\mathrm{g} / \mathrm{cm}^{2}\right)\end{array}$ & $\begin{array}{c}\text { Gravel } \\
(\%)\end{array}$ & $\begin{array}{c}\text { Sand } \\
(\%)\end{array}$ & $\begin{array}{c}\text { Silt } \\
(\%)\end{array}$ & $\begin{array}{c}\text { Clay } \\
(\%)\end{array}$ \\
\hline $0-2$ & 21.12 & ND & $2.15 \pm 0.22$ & 75.05 & 5.51 & 16.85 & 2.59 \\
\hline $2-4$ & 4.95 & ND & $5.12 \pm 0.51$ & 66.78 & 13.48 & 17.31 & 2.43 \\
\hline $4-6$ & 3.62 & ND & $8.36 \pm 0.84$ & 51.01 & 16.16 & 28.10 & 4.73 \\
\hline $6-8$ & 2.39 & ND & $11.67 \pm 1.17$ & 50.50 & 17.25 & 27.66 & 4.60 \\
\hline $8-10$ & 2.03 & ND & $15.02 \pm 1.50$ & 36.30 & 21.15 & 35.99 & 6.55 \\
\hline $10-12$ & 1.72 & ND & $18.39 \pm 1.84$ & 23.90 & 17.34 & 48.84 & 9.92 \\
\hline $12-14$ & 1.51 & ND & $21.79 \pm 2.18$ & 20.51 & 24.72 & 45.32 & 9.46 \\
\hline $14-16$ & 1.18 & ND & $25.24 \pm 2.52$ & 32.14 & 19.41 & 40.08 & 8.37 \\
\hline $16-18$ & 1.03 & ND & $28.76 \pm 2.88$ & 17.27 & 37.28 & 39.37 & 6.08 \\
\hline $18-20$ & 0.85 & ND & $32.32 \pm 3.23$ & 15.88 & 30.31 & 44.76 & 9.05 \\
\hline $20-25$ & 0.90 & ND & $41.35 \pm 4.13$ & 15.67 & 26.65 & 48.69 & 8.99 \\
\hline $25-30$ & 0.80 & ND & $50.52 \pm 5.05$ & 13.56 & 21.94 & 51.67 & 12.84 \\
\hline $30-35$ & 0.60 & ND & $59.77 \pm 5.98$ & 8.40 & 23.43 & 57.39 & 10.77 \\
\hline $35-40$ & 0.40 & ND & $69.01 \pm 6.90$ & 10.41 & 19.06 & 56.52 & 14.01 \\
\hline $40-45$ & 0.40 & ND & $78.22 \pm 7.82$ & 24.58 & 17.60 & 47.15 & 10.67 \\
\hline $45-50$ & 0.40 & ND & $87.40 \pm 8.74$ & 10.84 & 23.83 & 54.02 & 11.31 \\
\hline
\end{tabular}

\begin{tabular}{|c|c|c|c|c|c|c|c|}
\hline \multicolumn{7}{|c|}{ Table A7. RFFB_18T Sediment Physical Properties } \\
\hline $\begin{array}{c}\text { Sample } \\
\text { Interval } \\
(\mathrm{cm})\end{array}$ & $\begin{array}{c}\text { Organic } \\
\text { Carbon } \\
(\%)\end{array}$ & $\begin{array}{c}\text { Bulk density } \\
\left(\mathrm{g} / \mathrm{cm}^{3}\right)\end{array}$ & $\begin{array}{c}\text { Cumulative } \\
\text { Mass depth } \\
\left(\mathrm{g} / \mathrm{cm}^{2}\right)\end{array}$ & $\begin{array}{c}\text { Gravel } \\
(\%)\end{array}$ & $\begin{array}{c}\text { Sand } \\
(\%)\end{array}$ & $\begin{array}{c}\text { Silt } \\
(\%)\end{array}$ & $\begin{array}{c}\text { Clay } \\
(\%)\end{array}$ \\
\hline $0-2$ & 0.44 & 0.55 & $2.49 \pm 0.25$ & 17.58 & 58.68 & 20.95 & 2.80 \\
\hline $2-4$ & 0.18 & 0.76 & $5.98 \pm 0.60$ & 13.08 & 67.94 & 16.61 & 2.36 \\
\hline $4-6$ & 0.11 & 0.76 & $9.86 \pm 0.99$ & 17.15 & 59.63 & 20.54 & 2.69 \\
\hline $6-8$ & 0.16 & 0.79 & $13.49 \pm 1.35$ & 15.99 & 67.39 & 14.54 & 2.08 \\
\hline $8-10$ & 0.13 & 0.73 & $17.33 \pm 1.73$ & 16.21 & 60.84 & 20.48 & 2.47 \\
\hline $10-12$ & 0.11 & 0.83 & $20.81 \pm 2.08$ & 25.78 & 51.03 & 20.84 & 2.35 \\
\hline $12-14$ & 0.18 & 0.77 & $24.22 \pm 2.42$ & 17.77 & 55.18 & 23.99 & 3.07 \\
\hline $14-16$ & 0.18 & 0.78 & $27.65 \pm 2.76$ & 12.33 & 62.60 & 22.44 & 2.63 \\
\hline $16-18$ & 0.18 & 0.75 & $30.95 \pm 3.09$ & 22.50 & 55.73 & 19.48 & 2.29 \\
\hline $18-20$ & 0.12 & 0.88 & $34.26 \pm 3.43$ & 25.41 & 46.36 & 25.35 & 2.88 \\
\hline
\end{tabular}




\begin{tabular}{|l|l|l|l|l|l|l|l|}
\hline \multicolumn{1}{|c|}{ Table A7. Continued } \\
\hline $20-22$ & 0.14 & 0.83 & $37.50 \pm 3.75$ & 38.01 & 39.45 & 19.73 & 2.81 \\
\hline
\end{tabular}

\begin{tabular}{|c|c|c|c|c|c|c|c|}
\hline \multicolumn{7}{|c|}{ Table A8. RFGC_17T Sediment Physical Properties } \\
\hline $\begin{array}{c}\text { Sample } \\
\text { Interval } \\
(\mathrm{cm})\end{array}$ & $\begin{array}{c}\text { Organic } \\
\text { Carbon } \\
(\%)\end{array}$ & $\begin{array}{c}\text { Bulk density } \\
\left(\mathrm{g} / \mathrm{cm}^{3}\right)\end{array}$ & $\begin{array}{c}\text { Cumulative } \\
\text { Mass depth } \\
\left(\mathrm{g} / \mathrm{cm}^{2}\right)\end{array}$ & $\begin{array}{c}\text { Gravel } \\
(\%)\end{array}$ & $\begin{array}{c}\text { Sand } \\
(\%)\end{array}$ & $\begin{array}{c}\text { Silt } \\
(\%)\end{array}$ & $\begin{array}{c}\text { Clay } \\
(\%)\end{array}$ \\
\hline $0-2$ & 2.36 & 0.26 & $1.12 \pm 0.11$ & 2.99 & 26.76 & 62.30 & 7.95 \\
\hline $2-4$ & 1.81 & 0.64 & $3.56 \pm 0.36$ & 0.18 & 37.37 & 55.56 & 6.89 \\
\hline $4-6$ & 2.82 & 0.60 & $5.94 \pm 0.59$ & 0.10 & 25.51 & 63.51 & 10.88 \\
\hline $6-8$ & 1.98 & 0.51 & $7.97 \pm 0.80$ & 0.91 & 30.31 & 62.08 & 6.71 \\
\hline $8-10$ & 1.15 & 0.57 & $10.21 \pm 1.02$ & 0.64 & 43.96 & 50.01 & 5.38 \\
\hline $10-12$ & 0.30 & 0.81 & $13.50 \pm 1.35$ & 0.28 & 56.20 & 38.88 & 4.64 \\
\hline $12-14$ & 0.30 & 0.76 & $16.72 \pm 1.67$ & 1.46 & 58.99 & 35.53 & 4.02 \\
\hline $14-16$ & 0.20 & 0.79 & $20.22 \pm 2.02$ & 4.17 & 60.20 & 31.89 & 3.75 \\
\hline $16-18$ & 0.10 & 0.76 & $23.41 \pm 2.34$ & 4.24 & 57.53 & 34.57 & 3.66 \\
\hline $18-20$ & 0.22 & 0.67 & $26.27 \pm 2.63$ & 0.67 & 58.11 & 36.96 & 4.26 \\
\hline $20-22$ & 0.44 & 0.75 & $29.39 \pm 2.94$ & 1.26 & 60.32 & 34.37 & 4.05 \\
\hline $22-24$ & 0.37 & 0.80 & $32.48 \pm 3.25$ & 0.48 & 52.04 & 43.17 & 4.31 \\
\hline $24-26$ & 0.39 & 0.73 & $35.35 \pm 3.53$ & 2.46 & 54.84 & 38.52 & 4.18 \\
\hline
\end{tabular}

\begin{tabular}{|c|c|c|c|c|c|c|c|}
\hline \multicolumn{7}{|c|}{ Table A9. RFGC_17PC_A Sediment Physical Properties } \\
\hline $\begin{array}{c}\text { Sample } \\
\text { Interval } \\
(\mathrm{cm})\end{array}$ & $\begin{array}{c}\text { Organic } \\
\text { Carbon } \\
(\%)\end{array}$ & $\begin{array}{c}\text { Bulk density } \\
\left(\mathrm{g} / \mathrm{cm}^{3}\right)\end{array}$ & $\begin{array}{c}\text { Cumulative } \\
\text { Mass depth } \\
\left(\mathrm{g} / \mathrm{cm}^{2}\right)\end{array}$ & $\begin{array}{c}\text { Gravel } \\
(\%)\end{array}$ & $\begin{array}{c}\text { Sand } \\
(\%)\end{array}$ & $\begin{array}{c}\text { Silt } \\
(\%)\end{array}$ & $\begin{array}{c}\text { Clay } \\
(\%)\end{array}$ \\
\hline $0-1$ & 10.10 & 0.35 & $0.42 \pm 0.04$ & 0.00 & 7.11 & 79.12 & 13.78 \\
\hline $1-2$ & 6.00 & 0.35 & $0.83 \pm 0.08$ & 0.00 & 12.60 & 75.32 & 12.08 \\
\hline $2-3$ & 4.20 & 0.68 & $1.53 \pm 0.15$ & 0.00 & 10.08 & 77.59 & 12.32 \\
\hline $3-4$ & 4.60 & 0.68 & $2.22 \pm 0.22$ & 0.00 & 4.87 & 83.09 & 12.04 \\
\hline $4-5$ & 5.00 & 0.68 & $2.89 \pm 0.29$ & 0.00 & 5.59 & 82.40 & 12.02 \\
\hline $5-6$ & 2.70 & 0.68 & $3.56 \pm 0.36$ & 0.00 & 17.94 & 73.10 & 8.96 \\
\hline $6-7$ & 2.90 & 0.91 & $4.61 \pm 0.46$ & 0.00 & 20.61 & 70.53 & 8.86 \\
\hline $7-8$ & 1.70 & 0.91 & $5.66 \pm 0.57$ & 0.00 & 28.67 & 64.95 & 6.39 \\
\hline $8-9$ & 1.80 & 0.91 & $6.76 \pm 0.68$ & 0.00 & 27.98 & 65.40 & 6.62 \\
\hline $9-10$ & 1.00 & 0.91 & $7.86 \pm 0.79$ & 0.00 & 31.19 & 61.54 & 7.27 \\
\hline $10-11$ & 0.70 & 1.23 & $9.28 \pm 0.93$ & 0.00 & 36.09 & 56.67 & 7.24 \\
\hline $11-12$ & 0.90 & 1.23 & $10.71 \pm 1.07$ & 0.00 & 33.01 & 59.08 & 7.90 \\
\hline $12-13$ & 1.10 & 1.27 & $12.21 \pm 1.22$ & 0.00 & 30.69 & 61.27 & 8.04 \\
\hline $13-14$ & 0.50 & 1.27 & $13.71 \pm 1.37$ & 0.00 & 36.45 & 56.22 & 7.33 \\
\hline
\end{tabular}




\begin{tabular}{|c|c|c|c|c|c|c|c|}
\hline \multicolumn{8}{|c|}{ Table A9. Continued } \\
\hline $14-15$ & 0.50 & 1.35 & $15.31 \pm 1.53$ & 0.00 & 45.42 & 48.21 & 6.37 \\
\hline $15-16$ & 0.50 & 1.35 & $16.91 \pm 1.69$ & 1.14 & 51.70 & 40.79 & 6.38 \\
\hline $16-17$ & 0.50 & 1.51 & $18.54 \pm 1.85$ & 0.00 & 51.89 & 42.06 & 6.05 \\
\hline $17-18$ & 0.20 & 1.51 & $20.17 \pm 2.02$ & 0.00 & 56.00 & 38.56 & 5.44 \\
\hline 18-19 & 0.17 & 1.62 & $21.78 \pm 2.18$ & 0.00 & 51.99 & 42.31 & 5.70 \\
\hline $19-20$ & 0.22 & 1.62 & $23.40 \pm 2.34$ & 0.00 & 54.23 & 40.21 & 5.56 \\
\hline $20-21$ & 0.30 & 1.45 & $24.97 \pm 2.50$ & 0.00 & 56.95 & 37.70 & 5.34 \\
\hline $21-22$ & 0.30 & 1.45 & $26.54 \pm 2.65$ & 0.00 & 56.97 & 38.22 & 4.81 \\
\hline $22-23$ & 0.30 & 1.36 & $28.13 \pm 2.81$ & 0.00 & 53.91 & 39.79 & 6.30 \\
\hline $23-24$ & 0.30 & 1.36 & $29.73 \pm 2.97$ & 0.00 & 54.31 & 40.19 & 5.50 \\
\hline $24-25$ & 0.30 & 1.44 & $31.29 \pm 3.13$ & 0.00 & 51.13 & 42.70 & 6.17 \\
\hline $25-26$ & 0.30 & 1.44 & $32.86 \pm 3.29$ & 0.00 & 55.26 & 39.36 & 5.38 \\
\hline $26-27$ & 0.30 & 1.48 & $34.47 \pm 3.45$ & 0.00 & 62.13 & 33.43 & 4.43 \\
\hline $27-28$ & 0.30 & 1.48 & $36.08 \pm 3.61$ & 0.00 & 59.75 & 35.05 & 5.21 \\
\hline $28-29$ & 0.20 & 1.57 & $37.63 \pm 3.76$ & 0.00 & 57.16 & 37.94 & 4.90 \\
\hline $29-30$ & 0.30 & 1.57 & $39.18 \pm 3.92$ & 0.00 & 56.50 & 38.60 & 4.89 \\
\hline $30-31$ & 0.40 & 1.54 & $40.74 \pm 4.07$ & 2.99 & 46.01 & 45.40 & 5.60 \\
\hline $31-32$ & 0.30 & 1.54 & $42.29 \pm 4.23$ & 1.45 & 52.35 & 40.03 & 6.17 \\
\hline $32-33$ & 0.30 & 1.67 & $43.86 \pm 4.39$ & 0.88 & 52.67 & 41.04 & 5.41 \\
\hline $33-34$ & 0.40 & 1.67 & $45.44 \pm 4.54$ & 1.39 & 50.40 & 42.07 & 6.14 \\
\hline $34-35$ & 0.30 & 1.64 & $46.9 \pm 4.69$ & 5.17 & 57.03 & 33.30 & 4.50 \\
\hline $35-36$ & 0.50 & 1.64 & $48.37 \pm 4.84$ & 0.00 & 50.65 & 43.79 & 5.54 \\
\hline $36-37$ & 0.30 & 1.47 & $49.82 \pm 4.98$ & 1.70 & 51.18 & 41.57 & 5.54 \\
\hline $37-38$ & 0.40 & 1.47 & $51.27 \pm 5.13$ & 3.70 & 57.53 & 34.96 & 3.82 \\
\hline $38-39$ & 0.40 & 1.35 & $52.70 \pm 5.27$ & 1.82 & 52.20 & 40.76 & 5.22 \\
\hline $39-40$ & 0.40 & 1.35 & $54.12 \pm 5.41$ & 0.85 & 41.17 & 51.94 & 6.04 \\
\hline $40-41$ & 0.30 & 1.35 & $55.56 \pm 5.56$ & 0.16 & 56.03 & 38.52 & 5.29 \\
\hline $41-42$ & 0.80 & 1.35 & $57.01 \pm 5.70$ & 3.35 & 42.60 & 48.24 & 5.81 \\
\hline $42-43$ & 0.40 & 1.51 & $58.53 \pm 5.85$ & 0.00 & 48.57 & 46.34 & 5.09 \\
\hline $43-44$ & 0.70 & 1.51 & $60.06 \pm 6.01$ & 0.00 & 53.23 & 41.73 & 5.03 \\
\hline $44-45$ & 0.60 & 1.56 & $61.62 \pm 6.16$ & 0.32 & 37.26 & 54.71 & 7.72 \\
\hline $45-46$ & 0.50 & 1.56 & $63.18 \pm 6.32$ & 0.73 & 49.64 & 42.99 & 6.64 \\
\hline $46-47$ & 0.40 & 1.31 & $64.81 \pm 6.48$ & 0.33 & 46.99 & 45.97 & 6.71 \\
\hline $47-48$ & 0.40 & 1.31 & $66.43 \pm 6.64$ & 4.84 & 44.55 & 44.55 & 6.06 \\
\hline $48-49$ & 0.30 & 1.61 & $68.10 \pm 6.81$ & 0.15 & 45.05 & 48.03 & 6.77 \\
\hline $49-50$ & 0.30 & 1.61 & $69.78 \pm 6.98$ & 2.03 & 53.52 & 38.57 & 5.88 \\
\hline $50-52$ & 0.50 & 0.78 & ND & 5.81 & 49.58 & 39.00 & 5.61 \\
\hline $52-54$ & 0.30 & 0.88 & ND & 0.64 & 58.88 & 35.52 & 4.98 \\
\hline $54-56$ & 0.30 & 0.98 & ND & 1.00 & 47.90 & 44.33 & 6.77 \\
\hline
\end{tabular}




\begin{tabular}{|c|c|c|c|c|c|c|c|}
\hline \multicolumn{7}{|c|}{ Table A9. Continued } \\
\hline $56-58$ & 0.30 & 0.75 & ND & 0.70 & 52.16 & 41.36 & 5.78 \\
\hline $58-60$ & ND & 0.84 & ND & 0.81 & 43.99 & 49.41 & 5.79 \\
\hline $60-62$ & ND & 0.85 & ND & 5.82 & 49.62 & 39.26 & 5.29 \\
\hline $62-64$ & ND & 0.91 & ND & 2.71 & 48.10 & 43.62 & 5.58 \\
\hline $64-66$ & ND & 0.81 & ND & 6.80 & 48.78 & 39.76 & 4.66 \\
\hline $66-68$ & ND & 0.88 & ND & 0.55 & 52.46 & 41.91 & 5.09 \\
\hline $68-70$ & ND & 0.81 & ND & 22.72 & 42.93 & 30.89 & 3.46 \\
\hline $70-72$ & ND & 0.72 & ND & 16.31 & 44.16 & 35.22 & 4.31 \\
\hline $72-74$ & ND & 0.75 & ND & 11.38 & 35.96 & 47.25 & 5.42 \\
\hline $74-76$ & ND & 0.79 & ND & 15.29 & 39.03 & 41.06 & 4.62 \\
\hline $76-78$ & ND & 0.81 & ND & 4.35 & 51.17 & 40.45 & 4.03 \\
\hline $78-80$ & ND & 0.81 & ND & 7.60 & 50.41 & 38.06 & 3.93 \\
\hline $80-82$ & ND & 0.82 & ND & 9.85 & 42.37 & 43.14 & 4.65 \\
\hline $82-84$ & ND & 0.72 & ND & 13.50 & 34.74 & 46.50 & 5.27 \\
\hline $84-86$ & 0.30 & 0.80 & ND & 2.33 & 49.73 & 42.46 & 5.47 \\
\hline $86-88$ & ND & 0.73 & ND & 10.73 & 38.72 & 45.58 & 4.96 \\
\hline $88-90$ & 0.30 & 0.78 & ND & 5.00 & 50.84 & 39.37 & 4.79 \\
\hline $90-92$ & ND & 0.81 & ND & 4.15 & 66.52 & 25.79 & 3.53 \\
\hline $92-94$ & ND & 0.85 & ND & 6.14 & 52.89 & 35.97 & 5.00 \\
\hline $94-96$ & ND & 0.75 & ND & 5.16 & 58.74 & 31.73 & 4.37 \\
\hline
\end{tabular}

\begin{tabular}{|c|c|c|c|c|c|c|c|}
\hline \multicolumn{7}{|c|}{ Table A10. RFGC_17PC_B Sediment Physical Properties } \\
\hline $\begin{array}{c}\text { Sample } \\
\text { Interval } \\
(\mathrm{cm})\end{array}$ & $\begin{array}{c}\text { Organic } \\
\text { Carbon } \\
(\%)\end{array}$ & $\begin{array}{c}\text { Bulk density } \\
\left(\mathrm{g} / \mathrm{cm}^{3}\right)\end{array}$ & $\begin{array}{c}\text { Cumulative } \\
\text { Mass depth } \\
\left(\mathrm{g} / \mathrm{cm}^{2}\right)\end{array}$ & $\begin{array}{c}\text { Gravel } \\
(\%)\end{array}$ & $\begin{array}{c}\text { Sand } \\
(\%)\end{array}$ & $\begin{array}{c}\text { Silt } \\
(\%)\end{array}$ & $\begin{array}{c}\text { Clay } \\
(\%)\end{array}$ \\
\hline $0-1$ & 26.80 & 0.49 & $0.53 \pm 0.05$ & 0.00 & 2.30 & 90.11 & 7.59 \\
\hline $1-2$ & 9.84 & 0.49 & $1.67 \pm 0.17$ & 0.00 & 10.34 & 83.70 & 5.96 \\
\hline $2-3$ & 11.23 & 1.08 & $2.16 \pm 0.22$ & 0.00 & 17.35 & 76.38 & 6.27 \\
\hline $3-4$ & 5.43 & 1.08 & $2.93 \pm 0.29$ & 0.00 & 26.07 & 68.83 & 5.09 \\
\hline $4-5$ & 5.69 & 0.50 & $4.01 \pm 0.40$ & 0.00 & 17.16 & 70.22 & 12.62 \\
\hline $5-6$ & 6.08 & 0.50 & $5.11 \pm 0.51$ & 0.00 & 28.86 & 64.04 & 7.10 \\
\hline $6-7$ & 8.65 & 0.75 & $6.53 \pm 0.65$ & 0.00 & 10.15 & 80.98 & 8.88 \\
\hline $7-8$ & 6.67 & 0.75 & $8.02 \pm 0.80$ & 1.92 & 23.41 & 69.92 & 4.76 \\
\hline $8-9$ & 2.92 & 1.16 & $9.65 \pm 0.97$ & 0.00 & 29.08 & 63.62 & 7.31 \\
\hline $9-10$ & 2.67 & 1.16 & $11.29 \pm 1.13$ & 0.00 & 31.42 & 62.09 & 6.48 \\
\hline $10-11$ & 2.65 & 1.12 & $12.91 \pm 1.29$ & 0.00 & 30.22 & 65.26 & 4.53 \\
\hline $11-12$ & 2.11 & 1.12 & $14.48 \pm 1.45$ & 1.54 & 38.19 & 54.30 & 5.96 \\
\hline $12-13$ & 0.69 & 1.46 & $15.98 \pm 1.60$ & 0.00 & 45.74 & 48.89 & 5.37 \\
\hline $13-14$ & 0.51 & 1.46 & $17.47 \pm 1.75$ & 0.00 & 33.48 & 58.70 & 7.82 \\
\hline
\end{tabular}




\begin{tabular}{|c|c|c|c|c|c|c|c|}
\hline \multicolumn{8}{|c|}{ Table A10. Continued } \\
\hline $14-15$ & 0.50 & 1.52 & $18.91 \pm 1.89$ & 1.80 & 48.46 & 45.42 & 4.32 \\
\hline $15-16$ & 0.61 & 1.52 & $20.35 \pm 2.03$ & 2.39 & 41.99 & 51.28 & 4.33 \\
\hline $16-17$ & 0.41 & 1.54 & $21.68 \pm 2.17$ & 0.00 & 49.74 & 43.88 & 6.37 \\
\hline $17-18$ & 0.89 & 1.54 & $22.91 \pm 2.29$ & 0.89 & 54.60 & 39.48 & 5.03 \\
\hline $18-19$ & 0.47 & 1.45 & $24.25 \pm 2.42$ & 3.96 & 57.53 & 34.49 & 4.02 \\
\hline $19-20$ & 0.53 & 1.45 & $25.61 \pm 2.56$ & 8.80 & 53.35 & 33.88 & 3.96 \\
\hline $20-21$ & 0.55 & 1.74 & $27.02 \pm 2.70$ & 2.39 & 54.86 & 38.54 & 4.20 \\
\hline $21-22$ & 0.44 & 1.74 & $28.42 \pm 2.84$ & 0.88 & 55.85 & 38.67 & 4.59 \\
\hline $22-23$ & 0.66 & 1.46 & $29.90 \pm 2.99$ & 1.50 & 54.61 & 39.35 & 4.52 \\
\hline $23-24$ & 0.41 & 1.46 & $31.39 \pm 3.14$ & 7.55 & 50.16 & 37.96 & 4.32 \\
\hline $24-25$ & 0.41 & 1.58 & $32.98 \pm 3.30$ & 0.92 & 55.81 & 39.26 & 4.02 \\
\hline $25-26$ & 0.53 & 1.58 & $34.57 \pm 3.46$ & 0.86 & 54.76 & 40.49 & 3.89 \\
\hline $26-27$ & 0.43 & 1.48 & $36.08 \pm 3.61$ & 0.94 & 54.72 & 39.44 & 4.91 \\
\hline $27-28$ & 0.45 & 1.48 & $37.64 \pm 3.76$ & 0.55 & 54.87 & 39.35 & 5.22 \\
\hline $28-29$ & 0.55 & 1.41 & $39.24 \pm 3.92$ & 0.00 & 61.03 & 34.43 & 4.54 \\
\hline $29-30$ & 0.58 & 1.41 & $40.87 \pm 4.09$ & 0.71 & 51.54 & 42.26 & 5.49 \\
\hline $30-31$ & ND & 1.54 & $42.39 \pm 4.24$ & 1.38 & 53.05 & 40.73 & 4.83 \\
\hline $31-32$ & ND & 1.54 & $43.99 \pm 4.40$ & 0.44 & 50.76 & 43.10 & 5.70 \\
\hline $32-33$ & ND & 1.26 & $45.78 \pm 4.58$ & 0.42 & 50.28 & 44.35 & 4.96 \\
\hline $33-34$ & ND & 1.26 & $47.45 \pm 4.75$ & 0.00 & 50.50 & 43.97 & 5.54 \\
\hline $34-35$ & ND & 1.19 & $49.16 \pm 4.92$ & 0.00 & 53.97 & 40.67 & 5.36 \\
\hline $35-36$ & ND & 1.19 & $50.75 \pm 5.07$ & 0.89 & 47.44 & 45.63 & 6.03 \\
\hline $36-37$ & ND & 1.33 & $52.43 \pm 5.24$ & 0.00 & 47.78 & 46.42 & 5.80 \\
\hline $37-38$ & ND & 1.33 & $54.09 \pm 5.41$ & 0.00 & 50.66 & 43.79 & 5.55 \\
\hline $38-39$ & ND & 1.29 & $55.76 \pm 5.58$ & 0.00 & 56.07 & 39.08 & 4.85 \\
\hline $39-40$ & ND & 1.29 & $57.44 \pm 5.74$ & 0.00 & 44.32 & 50.66 & 4.82 \\
\hline $40-41$ & ND & 1.44 & $59.18 \pm 5.92$ & 0.00 & 49.45 & 45.57 & 4.99 \\
\hline $41-42$ & ND & 1.44 & $60.87 \pm 6.09$ & 0.45 & 49.74 & 44.15 & 5.65 \\
\hline $42-43$ & ND & 1.34 & $62.51 \pm 6.25$ & 1.06 & 44.84 & 48.39 & 5.71 \\
\hline $43-44$ & ND & 1.34 & $64.13 \pm 6.41$ & 3.15 & 44.59 & 46.82 & 5.45 \\
\hline $44-45$ & ND & 1.47 & $65.87 \pm 6.59$ & 0.00 & 44.96 & 49.32 & 5.72 \\
\hline $45-46$ & ND & 1.47 & $67.57 \pm 6.76$ & 0.00 & 46.21 & 48.27 & 5.52 \\
\hline $46-47$ & ND & 1.49 & $69.22 \pm 6.92$ & 0.00 & 43.63 & 50.42 & 5.94 \\
\hline $47-48$ & ND & 1.49 & $70.80 \pm 7.08$ & 0.89 & 42.61 & 50.67 & 5.83 \\
\hline $48-49$ & ND & 1.60 & $72.26 \pm 7.23$ & 0.00 & 48.01 & 45.71 & 6.28 \\
\hline $49-50$ & ND & 1.60 & ND & 0.00 & 48.32 & 45.35 & 6.34 \\
\hline $50-52$ & ND & 0.92 & ND & 0.00 & 48.41 & 45.92 & 5.66 \\
\hline $52-54$ & ND & 0.81 & ND & 0.17 & 50.41 & 43.37 & 6.04 \\
\hline $54-56$ & ND & 0.85 & ND & 0.00 & 58.90 & 35.76 & 5.33 \\
\hline
\end{tabular}




\begin{tabular}{|l|l|l|l|l|l|l|l|}
\hline \multicolumn{7}{|c|}{ Table A10. Continued } \\
\hline $56-58$ & ND & 0.83 & ND & 0.67 & 57.73 & 36.08 & 5.51 \\
\hline $58-60$ & ND & 0.82 & ND & 0.17 & 61.66 & 33.46 & 4.71 \\
\hline $60-62$ & ND & 0.78 & ND & 0.00 & 61.84 & 33.57 & 4.59 \\
\hline $62-64$ & ND & 0.72 & ND & 0.00 & 72.67 & 23.54 & 3.78 \\
\hline $64-66$ & ND & 0.70 & ND & 0.00 & 68.97 & 27.29 & 3.75 \\
\hline $66-68$ & ND & 0.67 & ND & 0.96 & 62.43 & 32.35 & 4.26 \\
\hline $68-70$ & ND & 0.82 & ND & 0.80 & 62.25 & 33.07 & 3.87 \\
\hline $70-72$ & ND & 0.76 & ND & 1.35 & 62.06 & 32.33 & 4.26 \\
\hline $72-74$ & ND & 0.85 & ND & 1.58 & 60.71 & 33.51 & 4.21 \\
\hline $74-76$ & ND & 0.75 & ND & 4.36 & 62.65 & 30.01 & 2.99 \\
\hline $76-78$ & ND & 0.76 & ND & 5.38 & 51.56 & 38.62 & 4.43 \\
\hline $78-80$ & ND & 0.71 & ND & 3.80 & 59.15 & 33.29 & 3.77 \\
\hline $80-82$ & ND & 0.84 & ND & 5.55 & 54.76 & 36.20 & 3.49 \\
\hline $82-84$ & ND & 0.74 & ND & 1.82 & 58.30 & 35.51 & 4.37 \\
\hline $84-86$ & ND & 0.63 & ND & 3.22 & 60.72 & 32.66 & 3.39 \\
\hline $86-88$ & ND & 0.76 & ND & 7.52 & 55.79 & 33.61 & 3.07 \\
\hline $88-90$ & ND & 0.73 & ND & 1.32 & 62.70 & 32.28 & 3.70 \\
\hline $90-92$ & ND & 0.74 & ND & 1.85 & 61.77 & 32.45 & 3.92 \\
\hline $92-94$ & ND & 0.75 & ND & 1.07 & 56.49 & 38.44 & 4.00 \\
\hline $94-96$ & ND & 0.76 & ND & 4.10 & 57.32 & 34.89 & 3.70 \\
\hline $96-98$ & ND & 0.75 & ND & 0.52 & 61.94 & 33.87 & 3.66 \\
\hline
\end{tabular}

\begin{tabular}{|c|c|c|c|c|c|c|c|}
\hline \multicolumn{7}{|c|}{ Table A11. VFWB_17PC_A Sediment Physical Properties } \\
\hline $\begin{array}{c}\text { Sample } \\
\text { Interval } \\
(\mathrm{cm})\end{array}$ & $\begin{array}{c}\text { Organic } \\
\text { Carbon } \\
(\%)\end{array}$ & $\begin{array}{c}\text { Bulk density } \\
\left(\mathrm{g} / \mathrm{cm}^{3}\right)\end{array}$ & $\begin{array}{c}\text { Cumulative } \\
\text { Mass depth } \\
\left(\mathrm{g} / \mathrm{cm}^{2}\right)\end{array}$ & $\begin{array}{c}\text { Gravel } \\
(\%)\end{array}$ & $\begin{array}{c}\text { Sand } \\
(\%)\end{array}$ & $\begin{array}{c}\text { Silt } \\
(\%)\end{array}$ & $\begin{array}{c}\text { Clay } \\
(\%)\end{array}$ \\
\hline $0-1$ & 4.50 & 1.05 & $1.07 \pm 0.11$ & 0.00 & 22.54 & 70.73 & 6.73 \\
\hline $1-2$ & 4.00 & 1.05 & $2.14 \pm 0.21$ & 0.00 & 26.09 & 62.04 & 11.86 \\
\hline $2-3$ & 1.73 & 1.74 & $3.80 \pm 0.38$ & 3.05 & 35.41 & 53.42 & 8.12 \\
\hline $3-4$ & 1.35 & 1.74 & $5.45 \pm 0.55$ & 7.55 & 29.56 & 56.12 & 6.75 \\
\hline $4-5$ & 1.03 & 1.74 & $7.08 \pm 0.71$ & 4.28 & 39.96 & 49.92 & 5.83 \\
\hline $5-6$ & 0.91 & 1.74 & $8.71 \pm 0.87$ & 9.02 & 33.18 & 50.92 & 6.88 \\
\hline $6-7$ & 0.98 & 1.61 & $10.36 \pm 1.04$ & 1.20 & 48.98 & 44.21 & 5.61 \\
\hline $7-8$ & 0.97 & 1.61 & $12.01 \pm 1.20$ & 12.53 & 32.72 & 48.14 & 6.62 \\
\hline $8-9$ & 0.60 & 1.58 & $13.71 \pm 1.37$ & 2.80 & 32.73 & 56.49 & 7.98 \\
\hline $9-10$ & 0.64 & 1.58 & $15.41 \pm 1.54$ & 26.77 & 22.57 & 44.22 & 6.45 \\
\hline $10-11$ & 0.37 & 1.71 & $17.13 \pm 1.71$ & 7.41 & 40.06 & 45.80 & 6.73 \\
\hline $11-12$ & 0.65 & 1.71 & $18.84 \pm 1.88$ & 6.84 & 35.67 & 51.50 & 5.99 \\
\hline $12-13$ & 0.68 & 1.70 & $20.49 \pm 2.05$ & 1.29 & 34.02 & 57.99 & 6.70 \\
\hline $13-14$ & 1.03 & 1.70 & $22.14 \pm 2.21$ & 14.35 & 29.67 & 48.92 & 7.06 \\
\hline
\end{tabular}




\begin{tabular}{|c|c|c|c|c|c|c|c|}
\hline \multicolumn{8}{|c|}{ Table A11. Continued } \\
\hline $14-15$ & 0.62 & 1.75 & $23.85 \pm 2.39$ & 11.51 & 37.47 & 44.15 & 6.87 \\
\hline $15-16$ & 1.15 & 1.75 & $25.56 \pm 2.56$ & 3.91 & 43.25 & 44.47 & 8.37 \\
\hline $16-17$ & 0.83 & 1.93 & $27.29 \pm 2.73$ & 3.66 & 37.47 & 49.97 & 8.90 \\
\hline $17-18$ & 0.77 & 1.93 & $29.01 \pm 2.90$ & 7.16 & 40.38 & 46.35 & 6.11 \\
\hline 18-19 & 1.20 & 1.69 & $30.76 \pm 3.08$ & 8.25 & 45.23 & 40.56 & 5.96 \\
\hline $19-20$ & 0.81 & 1.69 & $32.51 \pm 3.25$ & 6.10 & 35.81 & 51.64 & 6.44 \\
\hline $20-21$ & 0.90 & 1.62 & $34.18 \pm 3.42$ & 15.05 & 30.28 & 47.19 & 7.47 \\
\hline $21-22$ & 1.02 & 1.62 & $35.86 \pm 3.59$ & 5.26 & 46.79 & 41.50 & 6.44 \\
\hline $22-23$ & 1.29 & 1.76 & $37.53 \pm 3.75$ & 9.68 & 39.35 & 42.37 & 8.60 \\
\hline $23-24$ & 0.73 & 1.76 & $39.20 \pm 3.92$ & 2.48 & 35.87 & 51.33 & 10.32 \\
\hline $24-25$ & 0.73 & 1.66 & $40.86 \pm 4.09$ & 23.18 & 28.21 & 40.70 & 7.92 \\
\hline $25-26$ & 0.68 & 1.66 & $42.52 \pm 4.25$ & 3.31 & 33.39 & 54.94 & 8.36 \\
\hline $26-27$ & 0.77 & 1.71 & $44.20 \pm 4.42$ & 1.47 & 35.77 & 52.45 & 10.32 \\
\hline $27-28$ & 0.60 & 1.71 & $45.89 \pm 4.59$ & 27.04 & 24.85 & 40.27 & 7.85 \\
\hline $28-29$ & 0.75 & 1.84 & $47.64 \pm 4.76$ & 12.81 & 40.50 & 40.16 & 6.53 \\
\hline $29-30$ & 0.84 & 1.84 & $49.39 \pm 4.94$ & 2.92 & 41.38 & 48.25 & 7.45 \\
\hline $30-31$ & 0.85 & 1.78 & $51.10 \pm 5.11$ & 5.36 & 42.89 & 43.79 & 7.97 \\
\hline $31-32$ & 0.15 & 1.78 & $52.82 \pm 5.28$ & 13.01 & 49.50 & 33.14 & 4.36 \\
\hline $32-33$ & 0.77 & 1.87 & $54.55 \pm 5.46$ & 0.58 & 47.76 & 44.08 & 7.57 \\
\hline $33-34$ & 0.56 & 1.87 & $56.29 \pm 5.63$ & 2.26 & 63.24 & 30.18 & 4.32 \\
\hline $34-35$ & 0.76 & 1.84 & $57.98 \pm 5.80$ & 2.12 & 65.70 & 28.25 & 3.93 \\
\hline $35-36$ & 0.85 & 1.84 & $59.68 \pm 5.97$ & 10.83 & 38.93 & 42.17 & 6.50 \\
\hline $36-37$ & 0.62 & 1.88 & $61.39 \pm 6.14$ & 17.38 & 38.99 & 39.15 & 4.49 \\
\hline $37-38$ & 0.91 & 1.88 & $63.10 \pm 6.31$ & 17.13 & 36.31 & 40.77 & 5.79 \\
\hline $38-39$ & 1.10 & 1.66 & $64.78 \pm 6.48$ & 0.86 & 72.18 & 23.16 & 3.80 \\
\hline $39-40$ & 0.90 & 1.66 & $66.46 \pm 6.65$ & 7.13 & 33.82 & 52.93 & 6.12 \\
\hline $40-41$ & 1.48 & 1.66 & $68.11 \pm 6.81$ & 6.14 & 39.71 & 46.88 & 7.27 \\
\hline $41-42$ & 1.47 & 1.66 & $69.77 \pm 6.98$ & 3.74 & 39.28 & 48.41 & 8.57 \\
\hline $42-43$ & 0.98 & 1.47 & $71.44 \pm 7.14$ & 27.20 & 24.17 & 41.27 & 7.36 \\
\hline $43-44$ & 1.01 & 1.47 & $73.12 \pm 7.31$ & 6.84 & 34.10 & 52.07 & 7.00 \\
\hline $44-45$ & 0.93 & 1.69 & $74.78 \pm 7.48$ & 4.22 & 31.86 & 55.36 & 8.55 \\
\hline $45-46$ & 0.86 & 1.69 & $76.44 \pm 7.64$ & 7.92 & 41.84 & 43.48 & 6.75 \\
\hline $46-47$ & 0.79 & 1.72 & $78.20 \pm 7.82$ & 13.34 & 32.23 & 47.29 & 7.13 \\
\hline $47-48$ & 0.93 & 1.72 & $79.96 \pm 8.00$ & 4.51 & 42.45 & 47.13 & 5.90 \\
\hline $48-49$ & 0.84 & 1.64 & $81.63 \pm 8.16$ & 2.23 & 44.56 & 46.32 & 6.87 \\
\hline $49-50$ & 0.88 & 1.64 & $83.31 \pm 8.33$ & 6.40 & 34.97 & 51.25 & 7.38 \\
\hline $50-52$ & ND & 0.74 & $86.65 \pm 8.67$ & 14.63 & 33.89 & 44.00 & 7.48 \\
\hline $52-54$ & ND & 0.82 & $90.16 \pm 9.02$ & 8.29 & 37.97 & 46.21 & 7.51 \\
\hline $54-56$ & ND & 0.81 & $92.97 \pm 9.30$ & 5.81 & 39.81 & 47.23 & 7.14 \\
\hline $56-58$ & ND & 0.95 & $96.29 \pm 9.63$ & 22.42 & 34.05 & 37.50 & 6.03 \\
\hline $58-60$ & ND & 0.90 & $99.84 \pm 9.98$ & 6.22 & 34.53 & 50.46 & 8.80 \\
\hline $60-62$ & ND & 0.87 & ND & 19.56 & 36.42 & 37.95 & 6.08 \\
\hline
\end{tabular}




\begin{tabular}{|l|l|l|l|l|l|l|l|}
\hline \multicolumn{7}{|c|}{ Table A11. Continued } \\
\hline $62-64$ & ND & 0.85 & ND & 28.84 & 27.23 & 38.49 & 5.44 \\
\hline $64-66$ & ND & 0.74 & ND & 10.00 & 38.57 & 44.21 & 7.22 \\
\hline $66-68$ & ND & 0.80 & ND & 10.09 & 35.21 & 48.04 & 6.66 \\
\hline
\end{tabular}

\begin{tabular}{|c|c|c|c|c|c|c|c|}
\hline \multicolumn{7}{|c|}{ Table A12. SFMC_15 Sediment Physical Properties } \\
\hline $\begin{array}{c}\text { Sample } \\
\text { Interval } \\
(\mathrm{cm})\end{array}$ & $\begin{array}{c}\text { Organic } \\
\text { Carbon } \\
(\%)\end{array}$ & $\begin{array}{c}\text { Bulk density } \\
\left(\mathrm{g} / \mathrm{cm}^{3}\right)\end{array}$ & $\begin{array}{c}\text { Cumulative } \\
\text { Mass depth } \\
\left(\mathrm{g} / \mathrm{cm}^{2}\right)\end{array}$ & $\begin{array}{c}\text { Gravel } \\
(\%)\end{array}$ & $\begin{array}{c}\text { Sand } \\
(\%)\end{array}$ & $\begin{array}{c}\text { Silt } \\
(\%)\end{array}$ & $\begin{array}{c}\text { Clay } \\
(\%)\end{array}$ \\
\hline $0-2$ & 3.11 & ND & $1.58 \pm 0.16$ & 40.97 & 15.78 & 40.75 & 2.49 \\
\hline $2-4$ & 1.87 & ND & $3.46 \pm 0.35$ & 55.16 & 11.48 & 30.80 & 2.56 \\
\hline $4-6$ & 1.93 & ND & $5.68 \pm 0.57$ & 72.52 & 7.92 & 17.32 & 2.24 \\
\hline $6-8$ & 1.72 & ND & $8.18 \pm 0.82$ & 47.70 & 10.85 & 38.10 & 3.35 \\
\hline $8-10$ & 2.59 & ND & $10.75 \pm 1.08$ & 47.38 & 13.14 & 34.66 & 4.83 \\
\hline $10-12$ & 1.77 & ND & $13.35 \pm 1.34$ & 40.59 & 20.10 & 34.60 & 4.71 \\
\hline $12-14$ & 2.33 & ND & $15.97 \pm 1.60$ & 55.89 & 13.45 & 27.63 & 3.03 \\
\hline $14-16$ & 1.89 & ND & $18.63 \pm 1.86$ & 87.01 & 4.36 & 7.75 & 0.88 \\
\hline $16-18$ & 2.38 & ND & $21.22 \pm 2.12$ & 78.83 & 7.37 & 11.97 & 1.82 \\
\hline $18-20$ & 2.67 & ND & $23.80 \pm 2.38$ & 65.74 & 11.04 & 20.45 & 2.78 \\
\hline $20-25$ & 2.82 & ND & $30.12 \pm 3.01$ & 71.08 & 10.93 & 15.84 & 2.15 \\
\hline $25-30$ & 2.50 & ND & $36.12 \pm 3.61$ & 58.52 & 15.33 & 23.71 & 2.45 \\
\hline $30-35$ & 2.00 & ND & $42.20 \pm 4.22$ & 66.92 & 9.99 & 20.56 & 2.53 \\
\hline $35-40$ & 2.10 & ND & $48.24 \pm 4.82$ & 59.39 & 14.71 & 22.95 & 2.94 \\
\hline $40-45$ & 2.60 & ND & $54.10 \pm 5.41$ & 58.80 & 12.38 & 25.45 & 3.37 \\
\hline $45-50$ & ND & ND & ND & ND & ND & ND & ND \\
\hline
\end{tabular}

\begin{tabular}{|c|c|c|c|c|c|c|c|}
\hline \multicolumn{7}{|c|}{ Table A13. BM_07_16 Sediment Physical Properties } \\
\hline $\begin{array}{c}\text { Sample } \\
\text { Interval } \\
(\mathrm{cm})\end{array}$ & $\begin{array}{c}\text { Organic } \\
\text { Carbon } \\
(\%)\end{array}$ & $\begin{array}{c}\text { Bulk density } \\
\left(\mathrm{g} / \mathrm{cm}^{3}\right)\end{array}$ & $\begin{array}{c}\text { Cumulative } \\
\text { Mass depth } \\
\left(\mathrm{g} / \mathrm{cm}^{2}\right)\end{array}$ & $\begin{array}{c}\text { Gravel } \\
(\%)\end{array}$ & $\begin{array}{c}\text { Sand } \\
(\%)\end{array}$ & $\begin{array}{c}\text { Silt } \\
(\%)\end{array}$ & $\begin{array}{c}\text { Clay } \\
(\%)\end{array}$ \\
\hline $0-2$ & 0.70 & ND & $1.58 \pm 0.16$ & 30.58 & 40.80 & 26.16 & 2.46 \\
\hline $2-4$ & 0.30 & ND & $3.46 \pm 0.35$ & 34.50 & 37.13 & 25.13 & 3.25 \\
\hline $4-6$ & 0.30 & ND & $5.68 \pm 0.57$ & 27.30 & 45.04 & 25.15 & 2.51 \\
\hline $6-8$ & 0.30 & ND & $8.18 \pm 0.82$ & 25.27 & 49.48 & 22.82 & 2.43 \\
\hline $8-10$ & 0.20 & ND & $10.75 \pm 1.08$ & 20.38 & 46.99 & 29.16 & 3.47 \\
\hline $10-12$ & 0.20 & ND & $13.35 \pm 1.34$ & 28.74 & 43.82 & 24.48 & 2.96 \\
\hline $12-14$ & 0.20 & ND & $15.97 \pm 1.60$ & 37.00 & 38.77 & 21.26 & 2.97 \\
\hline $14-16$ & 0.30 & ND & $18.63 \pm 1.86$ & 32.18 & 43.31 & 21.74 & 2.77 \\
\hline $16-18$ & 0.40 & ND & $21.22 \pm 2.12$ & 39.26 & 40.18 & 18.46 & 2.10 \\
\hline $18-20$ & 0.20 & ND & $23.80 \pm 2.38$ & 31.93 & 35.92 & 29.16 & 2.99 \\
\hline
\end{tabular}




\begin{tabular}{|l|l|l|l|l|l|l|l|}
\hline \multicolumn{7}{|c|}{ Table A13. Continued } \\
\hline $20-25$ & 0.15 & ND & $30.12 \pm 3.01$ & 45.64 & 37.63 & 15.39 & 1.34 \\
\hline $25-30$ & 0.30 & ND & $36.12 \pm 3.61$ & 38.52 & 35.92 & 22.67 & 2.88 \\
\hline $30-35$ & 0.20 & ND & $42.20 \pm 4.22$ & 32.64 & 42.69 & 22.20 & 2.48 \\
\hline $35-40$ & 0.30 & ND & $48.24 \pm 4.82$ & 32.31 & 33.57 & 30.23 & 3.89 \\
\hline $40-45$ & 0.20 & ND & $54.10 \pm 5.41$ & 30.48 & 38.08 & 27.68 & 3.76 \\
\hline $45-50$ & 0.20 & ND & $59.87 \pm 5.99$ & 35.79 & 38.91 & 21.89 & 3.41 \\
\hline
\end{tabular}


Appendix B. ${ }^{7} \mathrm{Be},{ }^{137} \mathrm{Cs},{ }^{210} \mathrm{~Pb}$, and ${ }^{210} \mathrm{~Pb}$ xs Activities

\begin{tabular}{|c|c|c|c|c|}
\hline \multicolumn{5}{|c|}{ Table B1. RFMS_17T ${ }^{7} \mathrm{Be},{ }^{137} \mathrm{Cs},{ }^{210} \mathrm{~Pb}$, and ${ }^{210} \mathrm{~Pb}_{\text {xs }}$ Activities } \\
\hline $\begin{array}{c}\text { Sample Interval } \\
(\mathrm{cm})\end{array}$ & ${ }^{7} \mathrm{Be}(\mathrm{Bq} / \mathrm{kg})$ & $\begin{array}{c}{ }^{137} \mathrm{Cs} \\
(\mathrm{Bq} / \mathrm{kg})\end{array}$ & ${ }^{210} \mathrm{~Pb}(\mathrm{~Bq} / \mathrm{kg})$ & $\begin{array}{c}{ }^{210} \mathrm{~Pb} \text { xs } \\
(\mathrm{Bq} / \mathrm{kg})\end{array}$ \\
\hline $0-2$ & $5.33 \pm 0.62$ & $29.01 \pm 1.78$ & $119.35 \pm 5.86$ & $106.23 \pm 5.07$ \\
\hline $2-4$ & $0.00 \pm 0.00$ & $26.04 \pm 1.37$ & $65.71 \pm 3.81$ & $52.59 \pm 3.02$ \\
\hline $4-6$ & $0.00 \pm 0.00$ & $20.88 \pm 1.50$ & $47.93 \pm 2.88$ & $34.82 \pm 2.09$ \\
\hline $6-8$ & $0.00 \pm 0.00$ & $12.86 \pm 0.88$ & $41.77 \pm 2.63$ & $28.65 \pm 1.84$ \\
\hline $8-10$ & $0.00 \pm 0.00$ & $9.19 \pm 0.96$ & $30.36 \pm 2.00$ & $17.24 \pm 1.21$ \\
\hline $10-12$ & $0.00 \pm 0.00$ & $6.33 \pm 0.41$ & $28.66 \pm 1.66$ & $15.55 \pm 0.87$ \\
\hline $12-14$ & $0.00 \pm 0.00$ & $3.92 \pm 0.40$ & $23.75 \pm 1.36$ & $10.64 \pm 0.57$ \\
\hline $14-16$ & $0.00 \pm 0.00$ & $1.64 \pm 0.10$ & $19.15 \pm 1.12$ & $6.03 \pm 0.33$ \\
\hline $16-18$ & ND & $0.00 \pm 0.00$ & $11.69 \pm 0.73$ & ND \\
\hline $18-20$ & ND & $0.00 \pm 0.00$ & $12.04 \pm 0.79$ & ND \\
\hline $20-22$ & ND & $0.00 \pm 0.00$ & $9.40 \pm 0.58$ & ND \\
\hline $22-24$ & ND & $0.00 \pm 0.00$ & $14.65 \pm 0.84$ & ND \\
\hline $24-26$ & ND & $0.00 \pm 0.00$ & $12.04 \pm 0.73$ & ND \\
\hline $26-28$ & ND & $0.00 \pm 0.00$ & $10.76 \pm 0.66$ & ND \\
\hline $28-30$ & ND & $0.00 \pm 0.00$ & $10.26 \pm 0.70$ & ND \\
\hline $30-32$ & ND & $0.00 \pm 0.00$ & $10.11 \pm 0.67$ & ND \\
\hline $32-34$ & ND & $0.00 \pm 0.00$ & $10.20 \pm 0.62$ & ND \\
\hline $34-36$ & ND & $0.00 \pm 0.00$ & $10.41 \pm 0.66$ & ND \\
\hline $36-38$ & ND & $0.00 \pm 0.00$ & $10.83 \pm 0.59$ & ND \\
\hline $38-40$ & ND & $0.00 \pm 0.00$ & $12.56 \pm 0.80$ & ND \\
\hline $40-42$ & ND & $0.00 \pm 0.00$ & $12.14 \pm 0.83$ & ND \\
\hline $42-44$ & ND & $0.00 \pm 0.00$ & $13.23 \pm 0.88$ & ND \\
\hline $44-46$ & ND & $0.00 \pm 0.00$ & $12.99 \pm 0.81$ & ND \\
\hline $46-48$ & ND & $0.00 \pm 0.00$ & $13.22 \pm 0.80$ & ND \\
\hline $48-50$ & ND & $0.00 \pm 0.00$ & $13.14 \pm 0.76$ & ND \\
\hline
\end{tabular}

\begin{tabular}{|c|c|c|c|c|}
\hline \multicolumn{5}{|c|}{ Table B2. FCA_15 ${ }^{7} \mathrm{Be},{ }^{137} \mathrm{Cs},{ }^{210} \mathrm{~Pb}$, and ${ }^{210} \mathrm{~Pb}_{\text {xs }}$ Activities } \\
\hline $\begin{array}{c}\text { Sample Interval } \\
(\mathrm{cm})\end{array}$ & ${ }^{7} \mathrm{Be}(\mathrm{Bq} / \mathrm{kg})$ & ${ }^{137} \mathrm{Cs}(\mathrm{Bq} / \mathrm{kg})$ & ${ }^{210} \mathrm{~Pb}(\mathrm{~Bq} / \mathrm{kg})$ & ${ }^{210} \mathrm{~Pb}$ xs $(\mathrm{Bq} / \mathrm{kg})$ \\
\hline $0-2$ & $14.02 \pm 0.82$ & $28.09 \pm 1.72$ & $303.61 \pm 16.63$ & $285.08 \pm 15.54$ \\
\hline $2-4$ & $0.00 \pm 0.00$ & $12.64 \pm 0.77$ & $98.02 \pm 7.33$ & $79.49 \pm 6.23$ \\
\hline $4-6$ & $0.00 \pm 0.00$ & $29.35 \pm 1.82$ & $78.80 \pm 5.36$ & $60.27 \pm 4.26$ \\
\hline $6-8$ & $0.00 \pm 0.00$ & $27.14 \pm 1.65$ & $50.12 \pm 2.64$ & $31.59 \pm 1.55$ \\
\hline
\end{tabular}




\begin{tabular}{|c|c|c|c|c|}
\hline \multicolumn{5}{|c|}{ Table B2. Continued } \\
\hline $8-10$ & $0.00 \pm 0.00$ & $20.11 \pm 1.29$ & $36.07 \pm 2.40$ & $17.54 \pm 1.31$ \\
\hline $10-12$ & $0.00 \pm 0.00$ & $18.34 \pm 1.23$ & $37.14 \pm 2.59$ & $18.61 \pm 1.50$ \\
\hline $12-14$ & $0.00 \pm 0.00$ & $11.56 \pm 0.71$ & $25.93 \pm 1.58$ & $7.40 \pm 0.49$ \\
\hline $14-16$ & $0.00 \pm 0.00$ & $2.93 \pm 0.18$ & $43.15 \pm 2.69$ & $24.62 \pm 1.60$ \\
\hline $16-18$ & $0.00 \pm 0.00$ & $3.97 \pm 0.20$ & $31.13 \pm 2.10$ & $12.60 \pm 1.01$ \\
\hline $18-20$ & $0.00 \pm 0.00$ & $1.36 \pm 0.10$ & $20.62 \pm 1.27$ & $2.09 \pm 0.17$ \\
\hline $20-25$ & $0.00 \pm 0.00$ & $0.00 \pm 0.00$ & $21.42 \pm 1.40$ & $2.89 \pm 0.30$ \\
\hline $25-30$ & $0.00 \pm 0.00$ & $0.00 \pm 0.00$ & $22.21 \pm 1.38$ & $3.68 \pm 0.28$ \\
\hline $30-35$ & $0.00 \pm 0.00$ & $0.00 \pm 0.00$ & $18.04 \pm 1.00$ & ND \\
\hline $35-40$ & $0.00 \pm 0.00$ & $0.00 \pm 0.00$ & $17.02 \pm 0.91$ & ND \\
\hline $40-45$ & $0.00 \pm 0.00$ & $0.00 \pm 0.00$ & $22.13 \pm 1.37$ & ND \\
\hline $45-50$ & $0.00 \pm 0.00$ & $0.00 \pm 0.00$ & $16.44 \pm 1.01$ & ND \\
\hline
\end{tabular}

\begin{tabular}{|c|c|c|c|c|}
\hline \multicolumn{5}{|c|}{ Table B3. RFFB_18T ${ }^{7} \mathrm{Be}{ }^{137} \mathrm{Cs},{ }^{210} \mathrm{~Pb}$, and ${ }^{210} \mathrm{~Pb}$ xs Activities } \\
\hline Sample Interval (cm) & $\begin{array}{c}{ }^{7} \mathrm{Be} \\
(\mathrm{Bq} / \mathrm{kg})\end{array}$ & ${ }^{137} \mathrm{Cs}(\mathrm{Bq} / \mathrm{kg})$ & ${ }^{210} \mathrm{~Pb}(\mathrm{~Bq} / \mathrm{kg})$ & ${ }^{210} \mathrm{~Pb}_{\mathrm{xs}}(\mathrm{Bq} / \mathrm{kg})$ \\
\hline $0-2$ & ND & $0.00 \pm 0.00$ & $46.89 \pm 2.33$ & $23.08 \pm 0.92$ \\
\hline $2-4$ & ND & $0.00 \pm 0.00$ & $22.60 \pm 1.45$ & $0.00 \pm 0.00$ \\
\hline $4-6$ & ND & $0.00 \pm 0.00$ & $16.45 \pm 1.05$ & $0.00 \pm 0.00$ \\
\hline $6-8$ & ND & $0.00 \pm 0.00$ & $24.12 \pm 1.50$ & $0.00 \pm 0.00$ \\
\hline $8-10$ & ND & $0.00 \pm 0.00$ & $20.39 \pm 1.27$ & $0.00 \pm 0.00$ \\
\hline $10-12$ & ND & $0.00 \pm 0.00$ & $19.44 \pm 1.24$ & $0.00 \pm 0.00$ \\
\hline $12-14$ & ND & $0.00 \pm 0.00$ & $24.98 \pm 1.61$ & $1.17 \pm 0.20$ \\
\hline $14-16$ & ND & $0.00 \pm 0.00$ & $20.93 \pm 1.29$ & ND \\
\hline $16-18$ & ND & $0.00 \pm 0.00$ & $24.75 \pm 1.51$ & ND \\
\hline $18-20$ & ND & $0.00 \pm 0.00$ & $24.73 \pm 1.43$ & ND \\
\hline $20-22$ & ND & $0.00 \pm 0.00$ & $21.95 \pm 1.29$ & ND \\
\hline
\end{tabular}

\begin{tabular}{|c|c|c|c|c|}
\hline \multicolumn{5}{|c|}{ Table B4. RFGC_17T ${ }^{7} \mathrm{Be},{ }^{137} \mathrm{Cs},{ }^{210} \mathrm{~Pb}$, and ${ }^{210} \mathrm{~Pb}$ xs Activities } \\
\hline Sample Interval $(\mathrm{cm})$ & ${ }^{7} \mathrm{Be}(\mathrm{Bq} / \mathrm{kg})$ & ${ }^{137} \mathrm{Cs}(\mathrm{Bq} / \mathrm{kg})$ & ${ }^{210} \mathrm{~Pb}(\mathrm{~Bq} / \mathrm{kg})$ & ${ }^{210} \mathrm{~Pb}_{\mathrm{xs}}(\mathrm{Bq} / \mathrm{kg})$ \\
\hline $0-2$ & $4.48 \pm 0.27$ & $0.00 \pm 0.00$ & $67.89 \pm 4.89$ & $42.77 \pm 3.33$ \\
\hline $2-4$ & $0.00 \pm 0.00$ & $0.00 \pm 0.00$ & $51.39 \pm 3.36$ & $26.26 \pm 1.80$ \\
\hline $4-6$ & $0.00 \pm 0.00$ & $0.00 \pm 0.00$ & $55.92 \pm 3.90$ & $30.80 \pm 2.34$ \\
\hline $6-8$ & $0.00 \pm 0.00$ & $1.89 \pm 0.14$ & $52.94 \pm 3.10$ & $27.81 \pm 1.54$ \\
\hline $8-10$ & $0.00 \pm 0.00$ & $4.45 \pm 0.37$ & $46.99 \pm 3.01$ & $21.87 \pm 1.46$ \\
\hline $10-12$ & $0.00 \pm 0.00$ & $3.71 \pm 0.20$ & $29.90 \pm 1.87$ & $4.78 \pm 0.31$ \\
\hline $12-14$ & $0.00 \pm 0.00$ & $3.33 \pm 0.41$ & $23.78 \pm 1.53$ & $\mathrm{ND}$ \\
\hline $14-16$ & $0.00 \pm 0.00$ & $2.87 \pm 0.19$ & $22.07 \pm 1.40$ & $\mathrm{ND}$ \\
\hline
\end{tabular}




\begin{tabular}{|c|c|c|c|c|}
\hline \multicolumn{5}{|c|}{ Table B4. Continued } \\
\hline $16-18$ & $0.00 \pm 0.00$ & $3.51 \pm 0.38$ & $25.23 \pm 1.65$ & ND \\
\hline $18-20$ & $0.00 \pm 0.00$ & $4.35 \pm 0.26$ & $25.93 \pm 1.53$ & ND \\
\hline $20-22$ & $0.00 \pm 0.00$ & $5.81 \pm 0.70$ & $23.47 \pm 1.48$ & ND \\
\hline $22-24$ & $0.00 \pm 0.00$ & $11.01 \pm 0.76$ & $25.70 \pm 1.53$ & ND \\
\hline $24-26$ & $0.00 \pm 0.00$ & $11.60 \pm 1.01$ & $26.20 \pm 1.66$ & ND \\
\hline
\end{tabular}

\begin{tabular}{|c|c|c|c|c|}
\hline \multicolumn{5}{|c|}{ Table B5. RFGC_17PC_A ${ }^{7} \mathrm{Be},{ }^{137} \mathrm{Cs},{ }^{210} \mathrm{~Pb}$, and ${ }^{210} \mathrm{~Pb}$ xs Activities } \\
\hline $\begin{array}{c}\text { Sample Interval } \\
(\mathrm{cm})\end{array}$ & ${ }^{7} \mathrm{Be}(\mathrm{Bq} / \mathrm{kg})$ & ${ }^{137} \mathrm{Cs}(\mathrm{Bq} / \mathrm{kg})$ & ${ }^{210} \mathrm{~Pb}(\mathrm{~Bq} / \mathrm{kg})$ & ${ }^{210} \mathrm{~Pb}$ xs $(\mathrm{Bq} / \mathrm{kg})$ \\
\hline $0-1$ & $0.00 \pm 0.00$ & $0.00 \pm 0.00$ & $434.87 \pm 26.05$ & $410.27 \pm 24.67$ \\
\hline $1-2$ & ND & $0.00 \pm 0.00$ & $210.05 \pm 10.50$ & $185.45 \pm 9.12$ \\
\hline $2-3$ & ND & $0.00 \pm 0.00$ & $158.66 \pm 7.88$ & $134.06 \pm 6.51$ \\
\hline $3-4$ & ND & $0.00 \pm 0.00$ & $205.78 \pm 13.38$ & $181.18 \pm 12.01$ \\
\hline $4-5$ & ND & $0.00 \pm 0.00$ & $162.10 \pm 7.70$ & $137.50 \pm 6.33$ \\
\hline $5-6$ & ND & $0.00 \pm 0.00$ & $105.74 \pm 4.81$ & $81.14 \pm 3.43$ \\
\hline $6-7$ & ND & $0.00 \pm 0.00$ & $62.90 \pm 4.07$ & $38.30 \pm 2.69$ \\
\hline $7-8$ & ND & $0.00 \pm 0.00$ & $80.99 \pm 3.82$ & $56.39 \pm 2.45$ \\
\hline $8-9$ & ND & $3.07 \pm 0.21$ & $92.58 \pm 6.02$ & $67.98 \pm 4.65$ \\
\hline $9-10$ & ND & $1.95 \pm 0.18$ & $68.21 \pm 3.83$ & $43.61 \pm 2.46$ \\
\hline $10-11$ & ND & $3.22 \pm 0.21$ & $45.00 \pm 3.09$ & $20.40 \pm 1.72$ \\
\hline $11-12$ & ND & $2.62 \pm 0.17$ & $41.98 \pm 2.72$ & $17.38 \pm 1.34$ \\
\hline $12-13$ & ND & $3.94 \pm 0.34$ & $39.67 \pm 2.28$ & $15.07 \pm 0.90$ \\
\hline $13-14$ & ND & $5.09 \pm 0.32$ & $41.69 \pm 2.78$ & $17.09 \pm 1.41$ \\
\hline $14-15$ & ND & $5.12 \pm 0.32$ & $37.75 \pm 2.48$ & $13.15 \pm 1.10$ \\
\hline $15-16$ & ND & $3.48 \pm 0.26$ & $28.85 \pm 1.84$ & $4.25 \pm 0.46$ \\
\hline $16-17$ & ND & $4.32 \pm 0.29$ & $33.44 \pm 1.88$ & $8.84 \pm 0.50$ \\
\hline $17-18$ & ND & $3.84 \pm 0.32$ & $23.96 \pm 1.43$ & ND \\
\hline $18-19$ & ND & $3.15 \pm 0.18$ & $19.78 \pm 1.16$ & ND \\
\hline $19-20$ & ND & $4.03 \pm 0.27$ & $19.64 \pm 1.26$ & ND \\
\hline $20-21$ & ND & $5.82 \pm 0.31$ & $19.01 \pm 1.19$ & ND \\
\hline $21-22$ & ND & $5.16 \pm 0.41$ & $23.79 \pm 1.57$ & ND \\
\hline $22-23$ & ND & $5.64 \pm 0.52$ & $25.56 \pm 1.68$ & ND \\
\hline $23-24$ & ND & $7.11 \pm 0.52$ & $24.82 \pm 1.47$ & ND \\
\hline $24-25$ & ND & $7.81 \pm 0.55$ & $24.58 \pm 1.51$ & ND \\
\hline $25-26$ & ND & $10.17 \pm 0.71$ & $25.74 \pm 1.65$ & $1.14 \pm 0.28$ \\
\hline $26-27$ & ND & $7.16 \pm 0.48$ & $20.33 \pm 1.29$ & ND \\
\hline $27-28$ & ND & $8.85 \pm 0.70$ & $22.86 \pm 1.38$ & ND \\
\hline $28-29$ & ND & $8.75 \pm 0.82$ & $20.16 \pm 1.25$ & ND \\
\hline $29-30$ & ND & $14.00 \pm 0.93$ & $22.48 \pm 1.38$ & ND \\
\hline
\end{tabular}




\begin{tabular}{|c|c|c|c|c|}
\hline \multicolumn{5}{|c|}{ Table B5. Continued } \\
\hline $30-31$ & ND & $12.37 \pm 0.79$ & $23.59 \pm 1.49$ & ND \\
\hline $31-32$ & ND & $13.08 \pm 0.88$ & $24.15 \pm 1.37$ & ND \\
\hline $32-33$ & ND & $12.10 \pm 0.82$ & $25.17 \pm 1.31$ & ND \\
\hline $33-34$ & ND & $8.54 \pm 0.58$ & $24.32 \pm 1.68$ & ND \\
\hline $34-35$ & ND & $7.42 \pm 0.65$ & $25.45 \pm 1.32$ & ND \\
\hline $35-36$ & ND & $8.26 \pm 0.62$ & $24.42 \pm 1.26$ & ND \\
\hline $36-37$ & ND & $7.16 \pm 0.38$ & $27.18 \pm 1.70$ & $2.58 \pm 0.33$ \\
\hline $37-38$ & ND & $5.10 \pm 0.42$ & $30.92 \pm 1.64$ & $6.32 \pm 0.27$ \\
\hline $38-39$ & ND & $4.54 \pm 0.31$ & $31.06 \pm 1.62$ & $6.46 \pm 0.24$ \\
\hline $39-40$ & ND & $5.05 \pm 0.32$ & $29.08 \pm 1.81$ & $4.48 \pm 0.43$ \\
\hline $40-41$ & ND & $5.39 \pm 0.32$ & $33.41 \pm 1.61$ & $8.81 \pm 0.24$ \\
\hline $41-42$ & ND & $2.67 \pm 0.20$ & $32.40 \pm 1.72$ & $7.80 \pm 0.34$ \\
\hline $42-43$ & ND & $1.77 \pm 0.14$ & $30.45 \pm 1.88$ & $5.85 \pm 0.51$ \\
\hline $43-44$ & ND & $1.42 \pm 0.13$ & $28.00 \pm 1.78$ & $3.40 \pm 0.41$ \\
\hline $44-45$ & ND & $1.03 \pm 0.09$ & $28.21 \pm 1.45$ & $3.61 \pm 0.08$ \\
\hline $45-46$ & ND & ND & $26.08 \pm 1.52$ & $1.48 \pm 0.14$ \\
\hline $46-47$ & ND & ND & $24.64 \pm 1.61$ & ND \\
\hline $47-48$ & ND & ND & $26.16 \pm 1.27$ & $1.56 \pm 0.10$ \\
\hline $48-49$ & ND & ND & $23.57 \pm 1.33$ & ND \\
\hline $49-50$ & ND & $\mathrm{ND}$ & $24.07 \pm 1.52$ & $\mathrm{ND}$ \\
\hline $50-52$ & ND & $\mathrm{ND}$ & ND & ND \\
\hline $52-54$ & ND & ND & ND & ND \\
\hline $54-56$ & ND & ND & ND & ND \\
\hline 56-58 & ND & ND & ND & ND \\
\hline $58-60$ & ND & ND & ND & ND \\
\hline $60-62$ & ND & ND & ND & ND \\
\hline $62-64$ & ND & ND & ND & ND \\
\hline $64-66$ & ND & $\mathrm{ND}$ & ND & $\mathrm{ND}$ \\
\hline $66-68$ & ND & ND & ND & ND \\
\hline $68-70$ & ND & ND & ND & ND \\
\hline $70-72$ & ND & ND & ND & ND \\
\hline $72-74$ & ND & ND & ND & ND \\
\hline $74-76$ & ND & ND & ND & ND \\
\hline 76-78 & ND & ND & ND & ND \\
\hline $78-80$ & ND & $\mathrm{ND}$ & ND & $\mathrm{ND}$ \\
\hline $80-82$ & ND & ND & $\mathrm{ND}$ & ND \\
\hline $82-84$ & ND & ND & ND & ND \\
\hline $84-86$ & ND & ND & $\mathrm{ND}$ & ND \\
\hline $86-88$ & ND & ND & ND & ND \\
\hline
\end{tabular}




\begin{tabular}{|l|l|l|l|l|}
\hline \multicolumn{5}{|c|}{ Table B5. Continued } \\
\hline $88-90$ & ND & ND & ND & ND \\
\hline $90-92$ & ND & ND & ND & ND \\
\hline $92-94$ & ND & ND & ND & ND \\
\hline $94-96$ & ND & ND & ND & ND \\
\hline
\end{tabular}

\begin{tabular}{|c|c|c|c|c|}
\hline \multicolumn{5}{|c|}{ Table B6. RFGC_17PC_B ${ }^{7} \mathrm{Be},{ }^{137} \mathrm{Cs},{ }^{210} \mathrm{~Pb}$, and ${ }^{210} \mathrm{~Pb}$ xs Activities } \\
\hline $\begin{array}{l}\text { Sample Interval } \\
(\mathrm{cm})\end{array}$ & $\begin{array}{c}{ }^{7} \mathrm{Be} \\
(\mathrm{Bg} / \mathrm{kg})\end{array}$ & ${ }^{137} \mathrm{Cs}(\mathrm{Bq} / \mathrm{kg})$ & ${ }^{210} \mathrm{~Pb}(\mathrm{~Bq} / \mathrm{kg})$ & ${ }^{210} \mathrm{~Pb}$ xs $(\mathrm{Bq} / \mathrm{kg})$ \\
\hline $0-1$ & ND & $0.00 \pm 0.00$ & $450.73 \pm 21.10$ & $427.02 \pm 19.94$ \\
\hline $1-2$ & ND & $0.00 \pm 0.00$ & $363.77 \pm 16.73$ & $340.06 \pm 15.57$ \\
\hline $2-3$ & ND & $0.00 \pm 0.00$ & $165.01 \pm 7.24$ & $141.30 \pm 6.09$ \\
\hline 3-4 & ND & $0.00 \pm 0.00$ & $128.29 \pm 5.87$ & $104.58 \pm 4.71$ \\
\hline $4-5$ & ND & $0.00 \pm 0.00$ & $120.44 \pm 4.41$ & $96.73 \pm 3.25$ \\
\hline $5-6$ & ND & $0.00 \pm 0.00$ & $151.03 \pm 6.12$ & $127.31 \pm 4.96$ \\
\hline 6-7 & ND & $0.00 \pm 0.00$ & $171.40 \pm 7.24$ & $147.68 \pm 6.08$ \\
\hline $7-8$ & ND & $0.00 \pm 0.00$ & $113.85 \pm 4.15$ & $90.14 \pm 2.99$ \\
\hline $8-9$ & ND & $0.00 \pm 0.00$ & $61.93 \pm 2.60$ & $38.22 \pm 1.44$ \\
\hline $9-10$ & ND & $0.00 \pm 0.00$ & $73.07 \pm 2.75$ & $49.36 \pm 1.59$ \\
\hline $10-11$ & ND & $0.00 \pm 0.00$ & $99.27 \pm 6.44$ & $75.56 \pm 5.28$ \\
\hline $11-12$ & ND & $1.95 \pm 0.20$ & $93.20 \pm 6.49$ & $69.49 \pm 5.33$ \\
\hline $12-13$ & ND & $4.85 \pm 0.47$ & $63.05 \pm 3.18$ & $39.33 \pm 2.02$ \\
\hline $13-14$ & ND & $6.49 \pm 0.61$ & $71.39 \pm 4.37$ & $47.68 \pm 3.21$ \\
\hline $14-15$ & ND & $6.98 \pm 0.73$ & $54.49 \pm 2.86$ & $30.78 \pm 1.70$ \\
\hline $15-16$ & ND & $6.17 \pm 0.57$ & $43.41 \pm 1.98$ & $19.70 \pm 0.82$ \\
\hline $16-17$ & ND & $5.43 \pm 0.49$ & $48.76 \pm 2.85$ & $25.05 \pm 1.69$ \\
\hline $17-18$ & ND & $3.41 \pm 0.21$ & $35.06 \pm 2.25$ & $11.35 \pm 1.09$ \\
\hline 18-19 & ND & $4.17 \pm 0.46$ & $21.77 \pm 1.26$ & $\mathrm{ND}$ \\
\hline $19-20$ & ND & $4.90 \pm 0.32$ & $33.52 \pm 2.16$ & $9.8 \pm 1.00$ \\
\hline $20-21$ & ND & $5.47 \pm 0.33$ & $36.83 \pm 2.28$ & $13.12 \pm 1.12$ \\
\hline $21-22$ & ND & $5.93 \pm 0.49$ & $37.22 \pm 1.97$ & $13.50 \pm 0.81$ \\
\hline $22-23$ & ND & $4.72 \pm 0.33$ & $35.56 \pm 1.98$ & $11.85 \pm 0.82$ \\
\hline $23-24$ & ND & $7.13 \pm 0.53$ & $28.35 \pm 1.78$ & $4.64 \pm 0.62$ \\
\hline $24-25$ & ND & $8.15 \pm 0.67$ & $33.00 \pm 2.16$ & $9.29 \pm 1.00$ \\
\hline $25-26$ & ND & $8.20 \pm 0.71$ & $39.15 \pm 2.63$ & $15.43 \pm 1.47$ \\
\hline $26-27$ & ND & $7.62 \pm 0.56$ & $48.86 \pm 3.27$ & $25.15 \pm 2.11$ \\
\hline $27-28$ & ND & $9.28 \pm 0.66$ & $40.11 \pm 2.61$ & $16.39 \pm 1.45$ \\
\hline $28-29$ & ND & $9.80 \pm 0.66$ & $39.02 \pm 2.41$ & $15.31 \pm 1.25$ \\
\hline $29-30$ & ND & $17.38 \pm 1.06$ & $36.45 \pm 2.20$ & $12.74 \pm 1.04$ \\
\hline $30-31$ & ND & $15.25 \pm 1.14$ & $53.49 \pm 3.37$ & $29.78 \pm 2.21$ \\
\hline
\end{tabular}




\begin{tabular}{|c|c|c|c|c|}
\hline \multicolumn{5}{|c|}{ Table B6. Continued } \\
\hline $31-32$ & ND & $13.21 \pm 0.95$ & $42.65 \pm 2.80$ & $18.93 \pm 1.64$ \\
\hline $32-33$ & ND & $15.72 \pm 1.05$ & $45.91 \pm 3.15$ & $22.20 \pm 1.99$ \\
\hline $33-34$ & ND & $13.21 \pm 0.88$ & $45.82 \pm 2.74$ & $22.10 \pm 1.58$ \\
\hline $34-35$ & ND & $14.15 \pm 1.00$ & $41.03 \pm 2.84$ & $17.31 \pm 1.68$ \\
\hline $35-36$ & ND & $13.52 \pm 1.11$ & $55.77 \pm 3.95$ & $32.06 \pm 2.79$ \\
\hline $36-37$ & ND & $11.17 \pm 0.88$ & $44.58 \pm 2.56$ & $20.87 \pm 1.40$ \\
\hline $37-38$ & ND & $6.77 \pm 0.49$ & $45.31 \pm 2.93$ & $21.59 \pm 1.77$ \\
\hline $38-39$ & ND & $6.19 \pm 0.45$ & $45.43 \pm 2.75$ & $21.71 \pm 1.59$ \\
\hline $39-40$ & ND & $4.82 \pm 0.38$ & $37.56 \pm 2.24$ & $13.84 \pm 1.09$ \\
\hline $40-41$ & ND & $4.20 \pm 0.38$ & $48.39 \pm 3.32$ & $24.67 \pm 2.16$ \\
\hline $41-42$ & ND & $2.08 \pm 0.15$ & $43.50 \pm 2.60$ & $19.78 \pm 1.44$ \\
\hline $42-43$ & ND & $1.03 \pm 0.08$ & $43.79 \pm 2.64$ & $20.07 \pm 1.48$ \\
\hline $43-44$ & ND & $0.00 \pm 0.00$ & $45.02 \pm 2.52$ & $21.30 \pm 1.36$ \\
\hline $44-45$ & ND & $0.00 \pm 0.00$ & $49.07 \pm 3.09$ & $25.35 \pm 1.93$ \\
\hline $45-46$ & ND & $0.00 \pm 0.00$ & $48.20 \pm 3.00$ & $24.49 \pm 1.84$ \\
\hline $46-47$ & ND & $0.00 \pm 0.00$ & $47.57 \pm 3.07$ & $23.86 \pm 1.91$ \\
\hline $47-48$ & ND & ND & $44.53 \pm 2.86$ & $20.82 \pm 1.70$ \\
\hline $48-49$ & ND & ND & $47.17 \pm 2.64$ & $23.45 \pm 1.48$ \\
\hline $49-50$ & ND & ND & $40.02 \pm 2.50$ & $16.30 \pm 1.34$ \\
\hline $50-52$ & ND & ND & $34.84 \pm 2.23$ & $11.13 \pm 1.07$ \\
\hline $52-54$ & ND & ND & $42.53 \pm 2.77$ & $18.82 \pm 1.61$ \\
\hline $54-56$ & ND & ND & $41.42 \pm 2.76$ & $17.70 \pm 1.60$ \\
\hline $56-58$ & ND & ND & $24.62 \pm 1.56$ & $0.90 \pm 0.40$ \\
\hline $58-60$ & ND & ND & $30.78 \pm 1.55$ & $7.07 \pm 0.39$ \\
\hline $60-62$ & ND & ND & $21.28 \pm 1.34$ & ND \\
\hline $62-64$ & ND & ND & $18.62 \pm 1.20$ & ND \\
\hline $64-66$ & ND & ND & $13.42 \pm 0.99$ & ND \\
\hline $66-68$ & ND & ND & $22.51 \pm 1.37$ & ND \\
\hline $68-70$ & ND & ND & $21.50 \pm 1.42$ & ND \\
\hline $70-72$ & ND & ND & $24.93 \pm 1.30$ & $1.22 \pm 0.14$ \\
\hline $72-74$ & ND & ND & $31.70 \pm 1.36$ & $7.99 \pm 0.20$ \\
\hline $74-76$ & ND & ND & $36.87 \pm 1.58$ & $13.16 \pm 0.42$ \\
\hline $76-78$ & ND & ND & $37.26 \pm 1.61$ & $13.55 \pm 0.45$ \\
\hline $78-80$ & ND & ND & $34.63 \pm 1.62$ & $10.92 \pm 0.46$ \\
\hline $80-82$ & ND & ND & $33.16 \pm 1.44$ & $9.45 \pm 0.28$ \\
\hline $82-84$ & ND & ND & $23.92 \pm 1.13$ & ND \\
\hline $84-86$ & ND & ND & $30.37 \pm 1.21$ & $6.66 \pm 0.05$ \\
\hline $86-88$ & ND & ND & $23.70 \pm 1.16$ & ND \\
\hline $88-90$ & ND & ND & $17.07 \pm 1.11$ & ND \\
\hline
\end{tabular}




\begin{tabular}{|l|l|l|l|l|}
\hline \multicolumn{5}{|c|}{ Table B6. Continued } \\
\hline $90-92$ & ND & ND & ND & ND \\
\hline $92-94$ & ND & ND & ND & ND \\
\hline $94-96$ & ND & ND & ND & ND \\
\hline $96-98$ & ND & ND & ND & ND \\
\hline
\end{tabular}

\begin{tabular}{|c|c|c|c|c|}
\hline \multicolumn{5}{|c|}{ Table B7. VFWB_17PC_A ${ }^{7} \mathrm{Be},{ }^{137} \mathrm{Cs},{ }^{210} \mathrm{~Pb}$, and ${ }^{210} \mathrm{~Pb} \times \mathrm{xs}$ Activities } \\
\hline Sample Interval $(\mathrm{cm})$ & $\begin{array}{c}{ }^{7} \mathrm{Be} \\
(\mathrm{Bq} / \mathrm{kg})\end{array}$ & ${ }^{137} \mathrm{Cs}(\mathrm{Bq} / \mathrm{kg})$ & ${ }^{210} \mathrm{~Pb}(\mathrm{~Bq} / \mathrm{kg})$ & ${ }^{210} \mathrm{~Pb}$ xs $(\mathrm{Bq} / \mathrm{kg})$ \\
\hline $0-1$ & $\mathrm{ND}$ & ND & $55.41 \pm 2.42$ & $24.91 \pm 0.84$ \\
\hline $1-2$ & ND & ND & $50.47 \pm 2.80$ & $19.97 \pm 1.22$ \\
\hline $2-3$ & ND & ND & $28.48 \pm 1.77$ & ND \\
\hline $3-4$ & ND & ND & $31.80 \pm 1.89$ & $1.29 \pm 0.31$ \\
\hline $4-5$ & ND & ND & $30.35 \pm 1.78$ & ND \\
\hline $5-6$ & ND & ND & $32.83 \pm 1.93$ & $2.33 \pm 0.35$ \\
\hline 6-7 & ND & ND & $27.42 \pm 1.41$ & ND \\
\hline $7-8$ & ND & ND & $27.42 \pm 1.32$ & ND \\
\hline $8-9$ & ND & ND & $25.31 \pm 1.26$ & ND \\
\hline $9-10$ & ND & ND & $25.70 \pm 1.36$ & ND \\
\hline $10-11$ & ND & ND & $28.52 \pm 1.47$ & ND \\
\hline $11-12$ & ND & ND & $27.22 \pm 1.76$ & ND \\
\hline $12-13$ & ND & ND & $26.52 \pm 1.29$ & ND \\
\hline $13-14$ & ND & ND & $23.84 \pm 1.54$ & ND \\
\hline $14-15$ & ND & ND & $27.23 \pm 1.55$ & ND \\
\hline $15-16$ & ND & ND & $28.50 \pm 1.79$ & ND \\
\hline $16-17$ & ND & ND & $26.98 \pm 1.63$ & ND \\
\hline $17-18$ & ND & ND & $31.10 \pm 1.91$ & ND \\
\hline $18-19$ & ND & ND & $28.76 \pm 1.80$ & ND \\
\hline $19-20$ & ND & ND & $28.38 \pm 1.67$ & ND \\
\hline $20-21$ & ND & ND & $29.38 \pm 1.51$ & ND \\
\hline $21-22$ & ND & ND & $27.70 \pm 1.66$ & ND \\
\hline $22-23$ & ND & ND & $27.62 \pm 1.52$ & ND \\
\hline $23-24$ & ND & ND & $33.45 \pm 2.08$ & ND \\
\hline $24-25$ & ND & ND & $27.67 \pm 1.62$ & ND \\
\hline $25-26$ & ND & ND & $27.49 \pm 1.52$ & ND \\
\hline $26-27$ & ND & ND & $30.08 \pm 1.63$ & ND \\
\hline $27-28$ & ND & ND & $27.15 \pm 1.45$ & ND \\
\hline $28-29$ & ND & ND & $23.29 \pm 1.34$ & ND \\
\hline $29-30$ & ND & ND & $28.06 \pm 1.29$ & ND \\
\hline $30-31$ & ND & ND & ND & ND \\
\hline
\end{tabular}




\begin{tabular}{|c|c|c|c|c|}
\hline \multicolumn{5}{|c|}{ Table B7. Continued } \\
\hline $31-32$ & ND & ND & ND & ND \\
\hline $32-33$ & ND & ND & ND & ND \\
\hline $33-34$ & ND & ND & ND & ND \\
\hline $34-35$ & ND & ND & $29.94 \pm 1.62$ & ND \\
\hline $35-36$ & ND & ND & ND & ND \\
\hline $36-37$ & ND & ND & ND & ND \\
\hline $37-38$ & ND & ND & ND & ND \\
\hline $38-39$ & ND & ND & ND & ND \\
\hline $39-40$ & ND & ND & $29.85 \pm 1.63$ & ND \\
\hline $40-41$ & ND & ND & ND & ND \\
\hline $41-42$ & ND & ND & ND & ND \\
\hline $42-43$ & ND & ND & ND & ND \\
\hline $43-44$ & ND & ND & ND & ND \\
\hline $44-45$ & ND & ND & $29.68 \pm 1.45$ & ND \\
\hline $45-46$ & ND & ND & ND & ND \\
\hline $46-47$ & ND & ND & ND & ND \\
\hline $47-48$ & ND & ND & ND & ND \\
\hline $48-49$ & ND & ND & ND & ND \\
\hline $49-50$ & ND & ND & $31.97 \pm 1.66$ & ND \\
\hline $50-52$ & ND & ND & ND & ND \\
\hline $52-54$ & ND & ND & ND & ND \\
\hline $54-56$ & ND & ND & ND & ND \\
\hline $56-58$ & ND & ND & ND & ND \\
\hline $58-60$ & ND & ND & ND & ND \\
\hline $60-62$ & ND & ND & ND & ND \\
\hline $62-64$ & ND & ND & ND & ND \\
\hline $64-66$ & ND & ND & ND & ND \\
\hline $66-68$ & ND & ND & ND & ND \\
\hline
\end{tabular}

\begin{tabular}{|c|c|c|c|c|}
\hline \multicolumn{5}{|c|}{ Table B8. SFMC_15 ${ }^{7} \mathrm{Be},{ }^{137} \mathrm{Cs},{ }^{210} \mathrm{~Pb}$, and ${ }^{210} \mathrm{~Pb}$ xs Activities } \\
\hline $\begin{array}{c}\text { Sample Interval } \\
(\mathrm{cm})\end{array}$ & ${ }^{7} \mathrm{Be}(\mathrm{Bq} / \mathrm{kg})$ & ${ }^{137} \mathrm{Cs}(\mathrm{Bq} / \mathrm{kg})$ & ${ }^{210} \mathrm{~Pb}(\mathrm{~Bq} / \mathrm{kg})$ & ${ }^{210} \mathrm{~Pb}$ xs $(\mathrm{Bq} / \mathrm{kg})$ \\
\hline $0-2$ & $7.49 \pm 0.37$ & ND & $43.83 \pm 2.78$ & $33.19 \pm 2.14$ \\
\hline $2-4$ & $0.00 \pm 0.00$ & ND & $18.44 \pm 1.20$ & $7.80 \pm 0.56$ \\
\hline $4-6$ & $0.00 \pm 0.00$ & ND & $21.94 \pm 1.33$ & $11.29 \pm 0.69$ \\
\hline $6-8$ & $0.00 \pm 0.00$ & ND & $20.98 \pm 1.22$ & $10.33 \pm 0.58$ \\
\hline $8-10$ & $0.00 \pm 0.00$ & ND & $19.83 \pm 1.48$ & $9.18 \pm 0.84$ \\
\hline $10-12$ & $0.00 \pm 0.00$ & ND & $24.87 \pm 1.37$ & $14.22 \pm 0.73$ \\
\hline $12-14$ & $0.00 \pm 0.00$ & ND & $18.32 \pm 1.14$ & $7.67 \pm 0.49$ \\
\hline
\end{tabular}




\begin{tabular}{|c|c|c|c|c|}
\hline \multicolumn{5}{|c|}{ Table B8. Continued } \\
\hline $14-16$ & $0.00 \pm 0.00$ & ND & $20.90 \pm 1.25$ & $10.25 \pm 0.61$ \\
\hline $16-18$ & $0.00 \pm 0.00$ & ND & $14.67 \pm 1.10$ & $4.03 \pm 0.46$ \\
\hline $18-20$ & $0.00 \pm 0.00$ & ND & ND & ND \\
\hline $20-25$ & $0.00 \pm 0.00$ & ND & $11.07 \pm 0.71$ & ND \\
\hline $25-30$ & $0.00 \pm 0.00$ & ND & ND & ND \\
\hline $30-35$ & $0.00 \pm 0.00$ & ND & $12.36 \pm 0.71$ & ND \\
\hline $35-40$ & $0.00 \pm 0.00$ & ND & $8.52 \pm 0.50$ & ND \\
\hline $40-45$ & $0.00 \pm 0.00$ & ND & ND & ND \\
\hline $45-50$ & ND & ND & ND & ND \\
\hline
\end{tabular}

\begin{tabular}{|c|c|c|c|c|}
\hline \multicolumn{5}{|c|}{ Table B9. BM_07_16 ${ }^{7} \mathrm{Be},{ }^{137} \mathrm{Cs},{ }^{210} \mathrm{~Pb}$, and ${ }^{210} \mathrm{~Pb}$ xs Activities } \\
\hline Sample Interval (cm) & $\begin{array}{c}{ }^{7} \mathrm{Be} \\
(\mathrm{Bq} / \mathrm{kg})\end{array}$ & ${ }^{137} \mathrm{Cs}(\mathrm{Bq} / \mathrm{kg})$ & ${ }^{210} \mathrm{~Pb}(\mathrm{~Bq} / \mathrm{kg})$ & ${ }^{210} \mathrm{~Pb}$ xs $(\mathrm{Bq} / \mathrm{kg})$ \\
\hline $0-2$ & ND & ND & $6.65 \pm 0.46$ & $4.42 \pm 0.14$ \\
\hline $2-4$ & ND & ND & $2.66 \pm 0.25$ & ND \\
\hline $4-6$ & ND & ND & $2.42 \pm 0.19$ & ND \\
\hline $6-8$ & ND & ND & $2.17 \pm 0.20$ & ND \\
\hline $8-10$ & ND & ND & $1.73 \pm 0.21$ & ND \\
\hline $10-12$ & ND & ND & $2.02 \pm 0.26$ & ND \\
\hline $12-14$ & ND & ND & $1.98 \pm 0.27$ & ND \\
\hline $14-16$ & ND & ND & $2.66 \pm 0.32$ & ND \\
\hline $16-18$ & ND & ND & $2.25 \pm 0.28$ & ND \\
\hline $18-20$ & ND & ND & $2.32 \pm 0.28$ & ND \\
\hline $20-25$ & ND & ND & $2.20 \pm 0.36$ & ND \\
\hline $25-30$ & ND & ND & $2.19 \pm 0.28$ & ND \\
\hline $30-35$ & ND & ND & $1.84 \pm 0.30$ & ND \\
\hline $35-40$ & ND & ND & $2.06 \pm 0.33$ & ND \\
\hline $40-45$ & ND & ND & $2.78 \pm 0.34$ & ND \\
\hline $45-50$ & ND & ND & $1.87 \pm 0.29$ & ND \\
\hline
\end{tabular}


Appendix C. Stable Isotope and POC Values

\begin{tabular}{|c|c|c|}
\hline \multicolumn{3}{|c|}{ Table C1. RFMS_17T d $\mathrm{d}^{13} \mathrm{C}$ and POC } \\
\hline Sample Interval (cm) & $\begin{array}{l}\mathrm{d}^{13} \mathrm{C} \\
(\% \mathrm{o})\end{array}$ & Organic Carbon (\%) \\
\hline $0-2$ & -27.75 & 2.68 \\
\hline $2-4$ & -26.35 & 1.37 \\
\hline $4-6$ & -26.16 & 0.98 \\
\hline $6-8$ & -26.04 & 0.63 \\
\hline $8-10$ & -25.95 & 0.55 \\
\hline $10-12$ & -24.99 & 0.35 \\
\hline $12-14$ & -25.62 & 0.58 \\
\hline 14-16 & -25.60 & 0.29 \\
\hline 16-18 & ND & 0.15 \\
\hline $18-20$ & -27.29 & 0.25 \\
\hline $20-22$ & ND & 0.17 \\
\hline $22-24$ & -27.55 & 0.21 \\
\hline $24-26$ & -27.42 & 0.22 \\
\hline $26-28$ & -25.06 & 0.25 \\
\hline $28-30$ & -26.44 & 0.32 \\
\hline $30-32$ & -28.75 & 0.73 \\
\hline $32-34$ & -27.39 & 0.23 \\
\hline $34-36$ & ND & 0.13 \\
\hline $36-38$ & ND & 0.18 \\
\hline $38-40$ & -27.97 & 0.20 \\
\hline $40-42$ & ND & 0.16 \\
\hline $42-44$ & ND & 0.14 \\
\hline $44-46$ & ND & 0.12 \\
\hline $46-48$ & ND & 0.15 \\
\hline $48-50$ & -27.72 & 0.33 \\
\hline
\end{tabular}

\begin{tabular}{|c|c|c|}
\hline \multicolumn{3}{|c|}{ Table C2. FCA_15 $\mathrm{d}^{13} \mathrm{C}$ and POC } \\
\hline Sample Interval $(\mathrm{cm})$ & $\begin{array}{c}\mathrm{d}^{13} \mathrm{C} \\
(\%)\end{array}$ & Organic Carbon (\%) \\
\hline $0-2$ & -27.99 & 21.12 \\
\hline $2-4$ & -27.64 & 4.95 \\
\hline $4-6$ & -27.47 & 3.62 \\
\hline $6-8$ & -27.12 & 2.39 \\
\hline $8-10$ & -27.26 & 2.03 \\
\hline $10-12$ & -27.31 & 1.72 \\
\hline $12-14$ & -27.10 & 1.51 \\
\hline
\end{tabular}




\begin{tabular}{|c|c|c|}
\hline \multicolumn{3}{|c|}{ Table C2. Continued } \\
\hline $14-16$ & -27.25 & 1.18 \\
\hline $16-18$ & -27.07 & 1.03 \\
\hline $18-20$ & -26.99 & 0.85 \\
\hline $20-25$ & -26.90 & 0.90 \\
\hline $25-30$ & -26.74 & 0.80 \\
\hline $30-35$ & -26.13 & 0.60 \\
\hline $35-40$ & -26.33 & 0.40 \\
\hline $40-45$ & -26.09 & 0.40 \\
\hline $45-50$ & -26.67 & 0.40 \\
\hline
\end{tabular}

\begin{tabular}{|c|c|c|}
\hline \multicolumn{3}{|c|}{ Table C3. RFF_18T d ${ }^{13} \mathrm{C}$ and POC } \\
\hline Sample Interval (cm) & $\begin{array}{c}\mathrm{d}^{13} \mathrm{C} \\
(\%)\end{array}$ & Organic Carbon (\%) \\
\hline $0-2$ & -29.17 & 0.44 \\
\hline $2-4$ & ND & 0.18 \\
\hline $4-6$ & ND & 0.11 \\
\hline $6-8$ & ND & 0.16 \\
\hline $8-10$ & ND & 0.13 \\
\hline $10-12$ & ND & 0.11 \\
\hline $12-14$ & ND & 0.18 \\
\hline $14-16$ & ND & 0.18 \\
\hline $16-18$ & ND & 0.18 \\
\hline $18-20$ & ND & 0.12 \\
\hline $20-22$ & ND & 0.14 \\
\hline
\end{tabular}

\begin{tabular}{|c|c|c|}
\hline \multicolumn{3}{|c|}{ Table C4. RFG_17T $\mathrm{d}^{13} \mathrm{C}$ and POC } \\
\hline Sample Interval (cm) & $\begin{array}{c}\mathrm{d}^{13} \mathrm{C} \\
(\%)\end{array}$ & Organic Carbon (\%) \\
\hline $0-2$ & -28.04 & 2.36 \\
\hline $2-4$ & -27.12 & 1.81 \\
\hline $4-6$ & -27.92 & 2.82 \\
\hline $6-8$ & -27.13 & 1.98 \\
\hline $8-10$ & -28.93 & 1.15 \\
\hline $10-12$ & -28.11 & 0.30 \\
\hline $12-14$ & -27.50 & 0.30 \\
\hline $14-16$ & -28.38 & 0.20 \\
\hline $16-18$ & ND & 0.10 \\
\hline $18-20$ & -26.84 & 0.22 \\
\hline $20-22$ & -27.62 & 0.44 \\
\hline $22-24$ & -27.32 & 0.37 \\
\hline $24-26$ & -26.81 & 0.39 \\
\hline
\end{tabular}




\begin{tabular}{|c|c|c|}
\hline \multicolumn{3}{|c|}{ Table C5. RFGC_17PC_A d ${ }^{13} \mathrm{C}$ and POC } \\
\hline Sample Interval $(\mathrm{cm})$ & $\begin{array}{l}\mathrm{d}^{13} \mathrm{C} \\
(\%)\end{array}$ & Organic Carbon $(\%)$ \\
\hline $0-1$ & -31.00 & 10.10 \\
\hline $1-2$ & -29.70 & 6.00 \\
\hline $2-3$ & -28.70 & 4.20 \\
\hline $3-4$ & -29.60 & 4.60 \\
\hline $4-5$ & -29.30 & 5.00 \\
\hline $5-6$ & -27.00 & 2.70 \\
\hline $6-7$ & -25.80 & 2.90 \\
\hline $7-8$ & -26.20 & 1.70 \\
\hline $8-9$ & -27.40 & 1.80 \\
\hline $9-10$ & -26.40 & 1.00 \\
\hline $10-11$ & -27.90 & 0.70 \\
\hline $11-12$ & -26.10 & 0.90 \\
\hline $12-13$ & -26.50 & 1.10 \\
\hline $13-14$ & -27.30 & 0.50 \\
\hline $14-15$ & -28.30 & 0.50 \\
\hline $15-16$ & -27.80 & 0.50 \\
\hline $16-17$ & -27.60 & 0.50 \\
\hline $17-18$ & -27.30 & 0.20 \\
\hline $18-19$ & ND & 0.17 \\
\hline $19-20$ & -28.28 & 0.22 \\
\hline $20-21$ & -27.40 & 0.30 \\
\hline $21-22$ & -27.40 & 0.30 \\
\hline $22-23$ & -27.30 & 0.30 \\
\hline $23-24$ & -27.30 & 0.30 \\
\hline $24-25$ & -27.50 & 0.30 \\
\hline $25-26$ & -27.00 & 0.30 \\
\hline $26-27$ & -26.90 & 0.30 \\
\hline $27-28$ & -27.10 & 0.30 \\
\hline $28-29$ & -27.10 & 0.20 \\
\hline $29-30$ & -27.40 & 0.30 \\
\hline $30-31$ & -26.60 & 0.40 \\
\hline $31-32$ & -26.90 & 0.30 \\
\hline $32-33$ & -27.10 & 0.30 \\
\hline 33-34 & -26.70 & 0.40 \\
\hline $34-35$ & -27.30 & 0.30 \\
\hline $35-36$ & -27.40 & 0.50 \\
\hline $36-37$ & -27.70 & 0.30 \\
\hline $37-38$ & -27.80 & 0.40 \\
\hline $38-39$ & -27.10 & 0.40 \\
\hline $39-40$ & -27.30 & 0.40 \\
\hline
\end{tabular}




\begin{tabular}{|c|c|c|}
\hline \multicolumn{3}{|c|}{ Table C5. Continued } \\
\hline $40-41$ & -27.30 & 0.30 \\
\hline $41-42$ & -27.70 & 0.80 \\
\hline $42-43$ & -27.10 & 0.40 \\
\hline $43-44$ & -26.80 & 0.70 \\
\hline $44-45$ & -26.70 & 0.60 \\
\hline $45-46$ & -26.10 & 0.50 \\
\hline $46-47$ & -26.10 & 0.40 \\
\hline $47-48$ & -25.80 & 0.40 \\
\hline $48-49$ & -25.60 & 0.30 \\
\hline $49-50$ & -25.50 & 0.30 \\
\hline $50-52$ & -25.60 & 0.50 \\
\hline $52-54$ & -26.40 & 0.30 \\
\hline $54-56$ & -26.20 & 0.30 \\
\hline $56-58$ & -26.00 & 0.30 \\
\hline $58-60$ & ND & ND \\
\hline $60-62$ & ND & ND \\
\hline $62-64$ & ND & ND \\
\hline $64-66$ & ND & ND \\
\hline $66-68$ & ND & ND \\
\hline $68-70$ & ND & ND \\
\hline $70-72$ & ND & ND \\
\hline $72-74$ & $\mathrm{ND}$ & ND \\
\hline $74-76$ & $\mathrm{ND}$ & ND \\
\hline $76-78$ & $\mathrm{ND}$ & ND \\
\hline $78-80$ & ND & ND \\
\hline $80-82$ & ND & ND \\
\hline $82-84$ & ND & ND \\
\hline $84-86$ & -25.90 & 0.30 \\
\hline $86-88$ & ND & ND \\
\hline $88-90$ & -27.00 & 0.30 \\
\hline $90-92$ & ND & ND \\
\hline $92-94$ & ND & ND \\
\hline $94-96$ & ND & ND \\
\hline
\end{tabular}




\begin{tabular}{|c|c|c|}
\hline \multicolumn{3}{|c|}{ Table C6. RFGC_17PC_B d ${ }^{13} \mathrm{C}$ and POC } \\
\hline Sample Interval (cm) & $\begin{array}{l}\mathrm{d}^{13} \mathrm{C} \\
(\% \mathrm{o})\end{array}$ & Organic Carbon (\%) \\
\hline $0-1$ & ND & 26.80 \\
\hline $1-2$ & ND & 9.84 \\
\hline $2-3$ & ND & 11.23 \\
\hline $3-4$ & ND & 5.43 \\
\hline $4-5$ & $\mathrm{ND}$ & 5.69 \\
\hline $5-6$ & ND & 6.08 \\
\hline $6-7$ & ND & 8.65 \\
\hline $7-8$ & ND & 6.67 \\
\hline $8-9$ & -24.85 & 2.92 \\
\hline $9-10$ & -25.34 & 2.67 \\
\hline 10-11 & -25.77 & 2.65 \\
\hline $11-12$ & -26.98 & 2.11 \\
\hline $12-13$ & -28.19 & 0.69 \\
\hline $13-14$ & -28.15 & 0.51 \\
\hline $14-15$ & -28.51 & 0.50 \\
\hline $15-16$ & -28.98 & 0.61 \\
\hline $16-17$ & -28.60 & 0.41 \\
\hline $17-18$ & -28.48 & 0.89 \\
\hline $18-19$ & -28.11 & 0.47 \\
\hline $19-20$ & -28.17 & 0.53 \\
\hline $20-21$ & -27.70 & 0.55 \\
\hline $21-22$ & -28.06 & 0.44 \\
\hline $22-23$ & -26.72 & 0.66 \\
\hline $23-24$ & -28.06 & 0.41 \\
\hline $24-25$ & -27.82 & 0.41 \\
\hline $25-26$ & -28.06 & 0.53 \\
\hline $26-27$ & -27.64 & 0.43 \\
\hline $27-28$ & -28.26 & 0.45 \\
\hline $28-29$ & -28.08 & 0.55 \\
\hline $29-30$ & -27.92 & 0.58 \\
\hline $30-31$ & ND & ND \\
\hline $31-32$ & ND & ND \\
\hline $32-33$ & ND & ND \\
\hline 33-34 & ND & ND \\
\hline $34-35$ & ND & ND \\
\hline $35-36$ & ND & ND \\
\hline $36-37$ & ND & ND \\
\hline $37-38$ & ND & ND \\
\hline $38-39$ & ND & ND \\
\hline $39-40$ & ND & ND \\
\hline
\end{tabular}




\begin{tabular}{|c|c|c|}
\hline \multicolumn{3}{|c|}{ Table C6. Continued } \\
\hline $40-41$ & ND & ND \\
\hline $41-42$ & ND & ND \\
\hline $42-43$ & ND & ND \\
\hline $43-44$ & ND & ND \\
\hline $44-45$ & ND & ND \\
\hline $45-46$ & ND & ND \\
\hline $46-47$ & ND & ND \\
\hline $47-48$ & ND & ND \\
\hline $48-49$ & ND & ND \\
\hline $49-50$ & ND & ND \\
\hline $50-52$ & ND & ND \\
\hline $52-54$ & ND & ND \\
\hline $54-56$ & ND & ND \\
\hline $56-58$ & ND & ND \\
\hline $58-60$ & ND & ND \\
\hline $60-62$ & ND & ND \\
\hline $62-64$ & ND & ND \\
\hline $64-66$ & ND & ND \\
\hline $66-68$ & ND & ND \\
\hline $68-70$ & ND & ND \\
\hline $70-72$ & ND & ND \\
\hline $72-74$ & ND & ND \\
\hline $74-76$ & ND & ND \\
\hline $76-78$ & ND & ND \\
\hline $78-80$ & ND & ND \\
\hline $80-82$ & ND & ND \\
\hline $82-84$ & ND & ND \\
\hline $84-86$ & ND & ND \\
\hline $86-88$ & ND & ND \\
\hline $88-90$ & ND & ND \\
\hline $90-92$ & ND & ND \\
\hline 92-94 & ND & ND \\
\hline 94-96 & ND & ND \\
\hline $96-98$ & ND & ND \\
\hline
\end{tabular}




\begin{tabular}{|c|c|c|}
\hline \multicolumn{3}{|c|}{ Table C7. VFWB_17PC_A d ${ }^{13} \mathrm{C}$ and POC } \\
\hline Sample Interval (cm) & $\begin{array}{l}\mathrm{d}^{13} \mathrm{C} \\
(\% \mathrm{o})\end{array}$ & Organic Carbon (\%) \\
\hline $0-1$ & -27.42 & 4.50 \\
\hline $1-2$ & -27.77 & 4.00 \\
\hline $2-3$ & -25.86 & 1.73 \\
\hline $3-4$ & -26.33 & 1.35 \\
\hline $4-5$ & -26.29 & 1.03 \\
\hline $5-6$ & -26.04 & 0.91 \\
\hline 6-7 & -25.96 & 0.98 \\
\hline $7-8$ & -25.57 & 0.97 \\
\hline $8-9$ & -26.06 & 0.60 \\
\hline $9-10$ & -25.95 & 0.64 \\
\hline 10-11 & -26.54 & 0.37 \\
\hline $11-12$ & -26.19 & 0.65 \\
\hline $12-13$ & -26.75 & 0.68 \\
\hline $13-14$ & -25.57 & 1.03 \\
\hline $14-15$ & -25.76 & 0.62 \\
\hline $15-16$ & -25.99 & 1.15 \\
\hline $16-17$ & -26.55 & 0.83 \\
\hline $17-18$ & -26.52 & 0.77 \\
\hline $18-19$ & -25.96 & 1.20 \\
\hline $19-20$ & -25.58 & 0.81 \\
\hline $20-21$ & -26.62 & 0.90 \\
\hline $21-22$ & -26.38 & 1.02 \\
\hline $22-23$ & -28.02 & 1.29 \\
\hline $23-24$ & -26.36 & 0.73 \\
\hline $24-25$ & -26.39 & 0.73 \\
\hline $25-26$ & -26.11 & 0.68 \\
\hline $26-27$ & -26.03 & 0.77 \\
\hline $27-28$ & -26.21 & 0.60 \\
\hline $28-29$ & -26.45 & 0.75 \\
\hline $29-30$ & -26.43 & 0.84 \\
\hline $30-31$ & -26.80 & 0.85 \\
\hline $31-32$ & ND & 0.15 \\
\hline $32-33$ & -26.98 & 0.77 \\
\hline 33-34 & -26.35 & 0.56 \\
\hline $34-35$ & -26.37 & 0.76 \\
\hline $35-36$ & -26.22 & 0.85 \\
\hline $36-37$ & -26.21 & 0.62 \\
\hline $37-38$ & -25.86 & 0.91 \\
\hline $38-39$ & -25.44 & 1.10 \\
\hline $39-40$ & -26.35 & 0.90 \\
\hline
\end{tabular}




\begin{tabular}{|c|c|c|}
\hline \multicolumn{3}{|c|}{ Table C7. Continued } \\
\hline $40-41$ & -25.93 & 1.48 \\
\hline $41-42$ & -25.62 & 1.47 \\
\hline $42-43$ & -26.00 & 0.98 \\
\hline $43-44$ & -26.15 & 1.01 \\
\hline $44-45$ & -26.10 & 0.93 \\
\hline $45-46$ & -26.47 & 0.86 \\
\hline $46-47$ & -26.59 & 0.79 \\
\hline $47-48$ & -26.12 & 0.93 \\
\hline $48-49$ & -26.08 & 0.84 \\
\hline $49-50$ & -25.56 & 0.88 \\
\hline $50-52$ & ND & ND \\
\hline $52-54$ & ND & ND \\
\hline $54-56$ & ND & ND \\
\hline $56-58$ & ND & ND \\
\hline $58-60$ & ND & ND \\
\hline $60-62$ & ND & ND \\
\hline $62-64$ & ND & ND \\
\hline $64-66$ & ND & ND \\
\hline $66-68$ & ND & ND \\
\hline
\end{tabular}

\begin{tabular}{|c|c|c|}
\hline \multicolumn{3}{|c|}{ Table C8. SFMC_15 $\mathrm{d}^{13} \mathrm{C}$ and POC } \\
\hline Sample Interval (cm) & $\begin{array}{c}\mathrm{d}^{13} \mathrm{C} \\
(\%)\end{array}$ & Organic Carbon (\%) \\
\hline $0-2$ & -26.87 & 3.11 \\
\hline $2-4$ & -25.59 & 1.87 \\
\hline $4-6$ & -25.56 & 1.93 \\
\hline $6-8$ & -25.51 & 1.72 \\
\hline $8-10$ & -26.05 & 2.59 \\
\hline $10-12$ & -25.74 & 1.77 \\
\hline $12-14$ & -25.55 & 2.33 \\
\hline $14-16$ & -25.12 & 1.89 \\
\hline $16-18$ & -24.99 & 2.38 \\
\hline $18-20$ & -25.11 & 2.67 \\
\hline $20-25$ & -25.11 & 2.82 \\
\hline $25-30$ & -25.10 & 2.50 \\
\hline $30-35$ & -25.02 & 2.00 \\
\hline $35-40$ & -24.99 & 2.10 \\
\hline $40-45$ & -25.15 & 2.60 \\
\hline $45-50$ & ND & ND \\
\hline
\end{tabular}




\begin{tabular}{|c|c|c|}
\hline \multicolumn{3}{|c|}{ Table C9. BM_07_16 $\mathrm{d}^{13} \mathrm{C}$ and POC } \\
\hline Sample Interval (cm) & $\begin{array}{c}\mathrm{d}^{13} \mathrm{C} \\
(\%)\end{array}$ & Organic Carbon (\%) \\
\hline $0-2$ & -27.65 & 0.70 \\
\hline $2-4$ & -26.69 & 0.30 \\
\hline $4-6$ & -26.31 & 0.30 \\
\hline $6-8$ & -26.75 & 0.30 \\
\hline $8-10$ & -26.89 & 0.20 \\
\hline $10-12$ & -27.10 & 0.20 \\
\hline $12-14$ & -27.24 & 0.20 \\
\hline $14-16$ & -25.75 & 0.30 \\
\hline $16-18$ & -24.93 & 0.40 \\
\hline $18-20$ & -26.26 & 0.20 \\
\hline $20-25$ & -26.43 & 0.15 \\
\hline $25-30$ & -26.80 & 0.30 \\
\hline $30-35$ & -26.17 & 0.20 \\
\hline $35-40$ & -25.86 & 0.30 \\
\hline $40-45$ & -26.09 & 0.20 \\
\hline $45-50$ & -26.49 & 0.20 \\
\hline
\end{tabular}


Appendix D. Sediment Accumulation Rates

\begin{tabular}{|c|c|c|}
\hline \multicolumn{3}{|c|}{ Table D1. RFMS_17T Accumulation Rates } \\
\hline Time (Yr.) & SMARs $\left(\mathrm{g} \mathrm{cm}^{-2} \mathrm{yr}^{-1}\right)$ & LARs $\left(\mathrm{cm} \mathrm{yr}^{-1}\right)$ \\
\hline 14.61 & 0.22 & 0.16 \\
\hline 26.18 & 0.24 & 0.17 \\
\hline 36.80 & 0.20 & 0.15 \\
\hline 49.18 & 0.23 & 0.17 \\
\hline 61.09 & 0.16 & 0.12 \\
\hline 79.48 & 0.11 & 0.08 \\
\hline 112.31 & ND & ND \\
\hline
\end{tabular}

\begin{tabular}{|c|c|c|}
\hline \multicolumn{3}{|c|}{ Table D2. FCA_15 Accumulation Rates } \\
\hline Time (yr.) & SMARs $\left(\mathrm{g} \mathrm{cm}^{-2} \mathrm{yr}^{-1}\right)$ & LARs $\left(\mathrm{cm} \mathrm{yr}^{-1}\right)$ \\
\hline 15.48 & 0.19 & ND \\
\hline 25.39 & 0.33 & ND \\
\hline 36.94 & 0.29 & ND \\
\hline 45.46 & 0.39 & ND \\
\hline 51.50 & 0.56 & ND \\
\hline 59.50 & 0.42 & ND \\
\hline 63.37 & 0.89 & ND \\
\hline 81.62 & 0.19 & ND \\
\hline 97.91 & 0.22 & ND \\
\hline 101.69 & 2.39 & ND \\
\hline 120.18 & 0.50 & ND \\
\hline
\end{tabular}

\begin{tabular}{|c|c|c|}
\hline \multicolumn{3}{|c|}{ Table D3. RFFB_18T Accumulation Rates } \\
\hline Time (yr.) & SMARs $\left(\mathrm{g} \mathrm{cm}^{-2} \mathrm{yr}^{-1}\right)$ & LARs $\left(\mathrm{cm} \mathrm{yr}^{-1}\right)$ \\
\hline ND & ND & ND \\
\hline ND & ND & ND \\
\hline ND & ND & ND \\
\hline ND & ND & ND \\
\hline ND & ND & ND \\
\hline ND & ND & ND \\
\hline ND & ND & ND \\
\hline ND & ND & ND \\
\hline ND & ND & ND \\
\hline ND & ND & \\
\hline
\end{tabular}




\begin{tabular}{|c|c|c|}
\hline \multicolumn{3}{|c|}{ Table D4. RFGC_17T Accumulation Rates } \\
\hline Time (yr.) & SMARs $\left(\mathrm{g} \mathrm{cm}^{-2} \mathrm{yr}^{-1}\right)$ & LARs $\left(\mathrm{cm} \mathrm{yr}^{-1}\right)$ \\
\hline 5.10 & 0.27 & 0.24 \\
\hline 14.25 & 0.15 & 0.14 \\
\hline 29.66 & 0.10 & 0.09 \\
\hline 49.97 & 0.05 & 0.04 \\
\hline 95.79 & ND & ND \\
\hline
\end{tabular}

\begin{tabular}{|c|c|c|}
\hline \multicolumn{3}{|c|}{ Table D5. RFGC_17PC_A Accumulation Rates } \\
\hline Time (yr.) & SMARs $\left(\mathrm{g} \mathrm{cm}^{-2} \mathrm{yr}^{-1}\right)$ & LARs $\left(\mathrm{cm} \mathrm{yr}^{-1}\right)$ \\
\hline 5.50 & 0.15 & 0.15 \\
\hline 8.35 & 0.18 & 0.19 \\
\hline 12.23 & 0.11 & 0.12 \\
\hline 18.35 & 0.13 & 0.13 \\
\hline 23.72 & 0.18 & 0.19 \\
\hline 27.39 & 0.35 & 0.36 \\
\hline 30.42 & 0.21 & 0.22 \\
\hline 35.48 & 0.14 & 0.15 \\
\hline 43.29 & 0.18 & 0.18 \\
\hline 49.54 & 0.32 & 0.33 \\
\hline 54.03 & 0.32 & 0.34 \\
\hline 58.43 & 0.33 & 0.34 \\
\hline 63.04 & 0.24 & 0.25 \\
\hline 69.23 & 0.26 & 0.27 \\
\hline 75.40 & 0.71 & 0.74 \\
\hline 77.68 & 0.30 & 0.31 \\
\hline 85.429 & 0.336 & 0.35 \\
\hline 89.743 & 0.285 & 0.30 \\
\hline 94.738 & 0.357 & 0.37 \\
\hline 98.721 & 0.15 & 0.15 \\
\hline 108.533 & 0.12 & 0.12 \\
\hline
\end{tabular}

\begin{tabular}{|c|c|c|}
\hline \multicolumn{3}{|c|}{ Table D6. RFGC_17PC_B Accumulation Rates } \\
\hline Time (yr.) & SMARs $\left(\mathrm{g} \mathrm{cm}^{-2} \mathrm{yr}^{-1}\right)$ & LARs $\left(\mathrm{cm} \mathrm{yr}^{-1}\right)$ \\
\hline 2.60 & 0.23 & 0.17 \\
\hline 7.67 & 0.49 & 0.38 \\
\hline 8.66 & 0.64 & 0.50 \\
\hline 9.85 & 0.67 & 0.51 \\
\hline 11.47 & 0.48 & 0.37 \\
\hline 13.79 & 0.37 & 0.29 \\
\hline
\end{tabular}




\begin{tabular}{|c|c|c|}
\hline \multicolumn{3}{|c|}{ Table D6. Continued } \\
\hline 17.56 & 0.55 & 0.43 \\
\hline 20.26 & 1.23 & 0.94 \\
\hline 21.58 & 0.91 & 0.70 \\
\hline 23.39 & 0.55 & 0.42 \\
\hline 26.34 & 0.55 & 0.42 \\
\hline 29.20 & 0.90 & 0.69 \\
\hline 30.86 & 0.70 & 0.54 \\
\hline 32.99 & 1.03 & 0.79 \\
\hline 34.39 & 1.55 & 1.19 \\
\hline 35.32 & 1.18 & 0.91 \\
\hline 36.45 & 2.54 & 1.95 \\
\hline 36.93 & ND & ND \\
\hline 36.93 & 2.90 & 2.22 \\
\hline 37.41 & 2.13 & 1.63 \\
\hline 38.07 & 2.02 & 1.55 \\
\hline 38.76 & 2.26 & 1.73 \\
\hline 39.42 & 5.69 & 4.37 \\
\hline 39.68 & 2.80 & 2.15 \\
\hline 40.24 & 1.65 & 1.27 \\
\hline 41.21 & 0.97 & 0.75 \\
\hline 42.76 & 1.43 & 1.10 \\
\hline 43.85 & 1.48 & 1.14 \\
\hline 44.93 & 1.73 & 1.33 \\
\hline 45.88 & 0.70 & 0.54 \\
\hline 48.03 & 1.05 & 0.80 \\
\hline 49.56 & 0.84 & 0.65 \\
\hline 51.68 & 0.79 & 0.61 \\
\hline 53.80 & 0.95 & 0.73 \\
\hline 55.58 & 0.48 & 0.37 \\
\hline 58.93 & 0.67 & 0.51 \\
\hline 61.46 & 0.59 & 0.46 \\
\hline 64.25 & 0.54 & 0.41 \\
\hline 67.35 & 0.78 & 0.60 \\
\hline 69.51 & 0.39 & 0.30 \\
\hline 73.91 & 0.43 & 0.33 \\
\hline 77.82 & 0.38 & 0.29 \\
\hline 82.19 & 0.30 & 0.23 \\
\hline 87.51 & 0.21 & 0.16 \\
\hline 95.94 & 0.16 & 0.12 \\
\hline 106.59 & ND & ND \\
\hline
\end{tabular}




\begin{tabular}{|c|c|c|}
\hline \multicolumn{3}{|c|}{ Table D7. VFWB_17PC_A Accumulation Rates } \\
\hline Time (yr.) & SMARs $\left(\mathrm{g} \mathrm{cm}^{-2} \mathrm{yr}^{-1}\right)$ & LARs $\left(\mathrm{cm} \mathrm{yr}^{-1}\right)$ \\
\hline 21.30 & 0.02 & 0.01 \\
\hline 70.59 & ND & ND \\
\hline 70.59 & 0.11 & 0.07 \\
\hline 85.02 & ND & ND \\
\hline 85.02 & ND & ND \\
\hline
\end{tabular}

\begin{tabular}{|c|c|c|}
\hline \multicolumn{3}{|c|}{ Table D9. SFMC_15 Accumulation Rates } \\
\hline Time (yr.) & SMARs $\left(\mathrm{g} \mathrm{cm}^{-2} \mathrm{yr}^{-1}\right)$ & LARs $\left(\mathrm{cm} \mathrm{yr}^{-1}\right)$ \\
\hline 9.99 & 0.86 & ND \\
\hline 13.38 & 0.66 & ND \\
\hline 19.03 & 0.62 & ND \\
\hline 25.29 & ND & ND \\
\hline 31.79 & 0.45 & ND \\
\hline 45.43 & 0.52 & ND \\
\hline 56.55 & 0.38 & ND \\
\hline 82.53 & 0.53 & ND \\
\hline 103.67 & ND & ND \\
\hline
\end{tabular}

\begin{tabular}{|c|c|c|}
\hline \multicolumn{3}{|c|}{ Table D9. BM_07_16 Accumulation Rates } \\
\hline Time (yr.) & SMARs $\left(\mathrm{gcm}^{-2} \mathrm{yr}^{-1}\right)$ & LARs $\left(\mathrm{cm} \mathrm{yr}^{-1}\right)$ \\
\hline ND & ND & ND \\
\hline ND & ND & ND \\
\hline ND & ND & ND \\
\hline ND & ND & ND \\
\hline ND & ND & ND \\
\hline ND & ND & ND \\
\hline ND & ND & ND \\
\hline ND & ND & ND \\
\hline ND & ND & ND \\
\hline ND & ND & ND \\
\hline ND & ND & ND \\
\hline ND & ND & ND \\
\hline ND & ND & ND \\
\hline ND & ND & \\
\hline ND & ND & \\
\hline
\end{tabular}



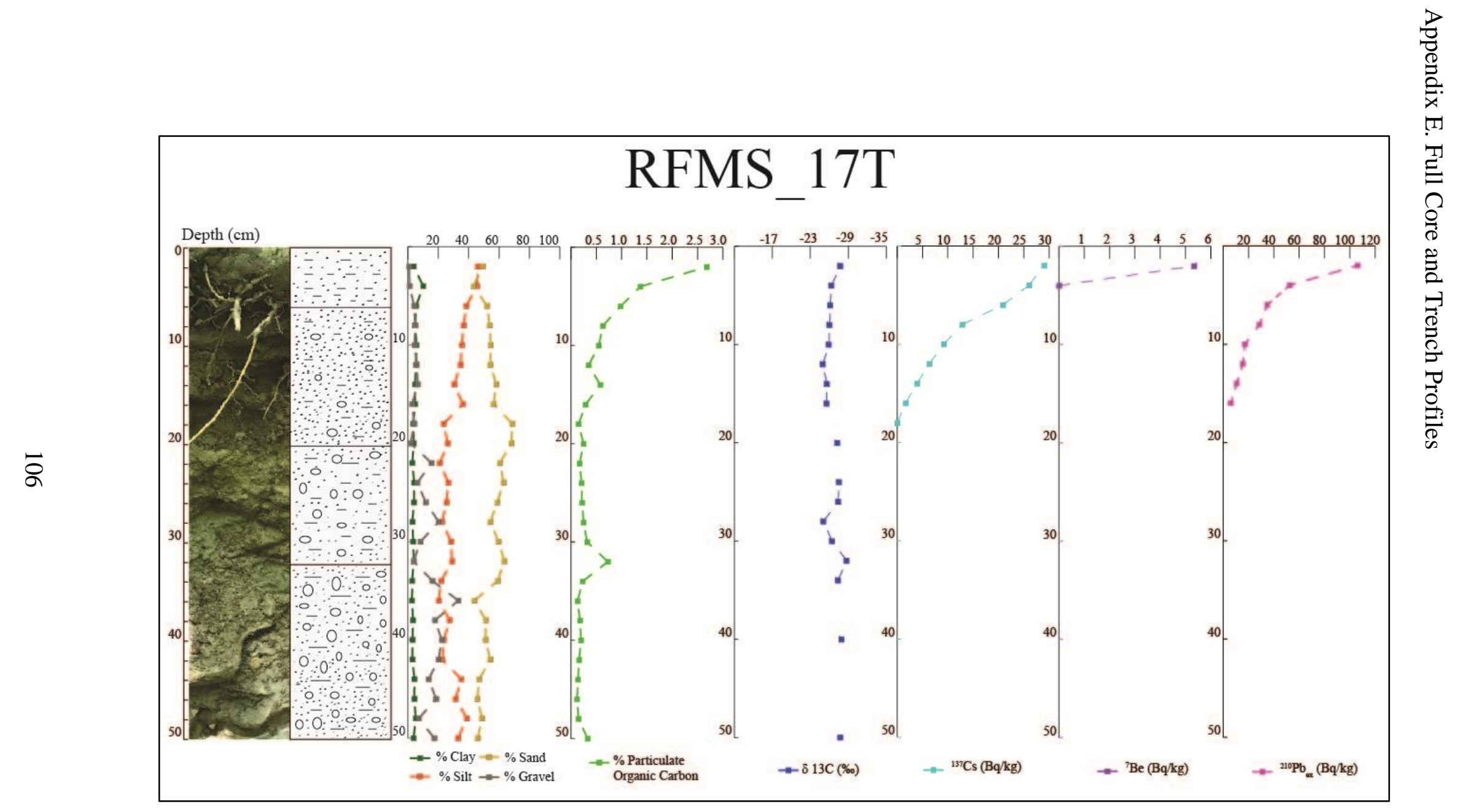


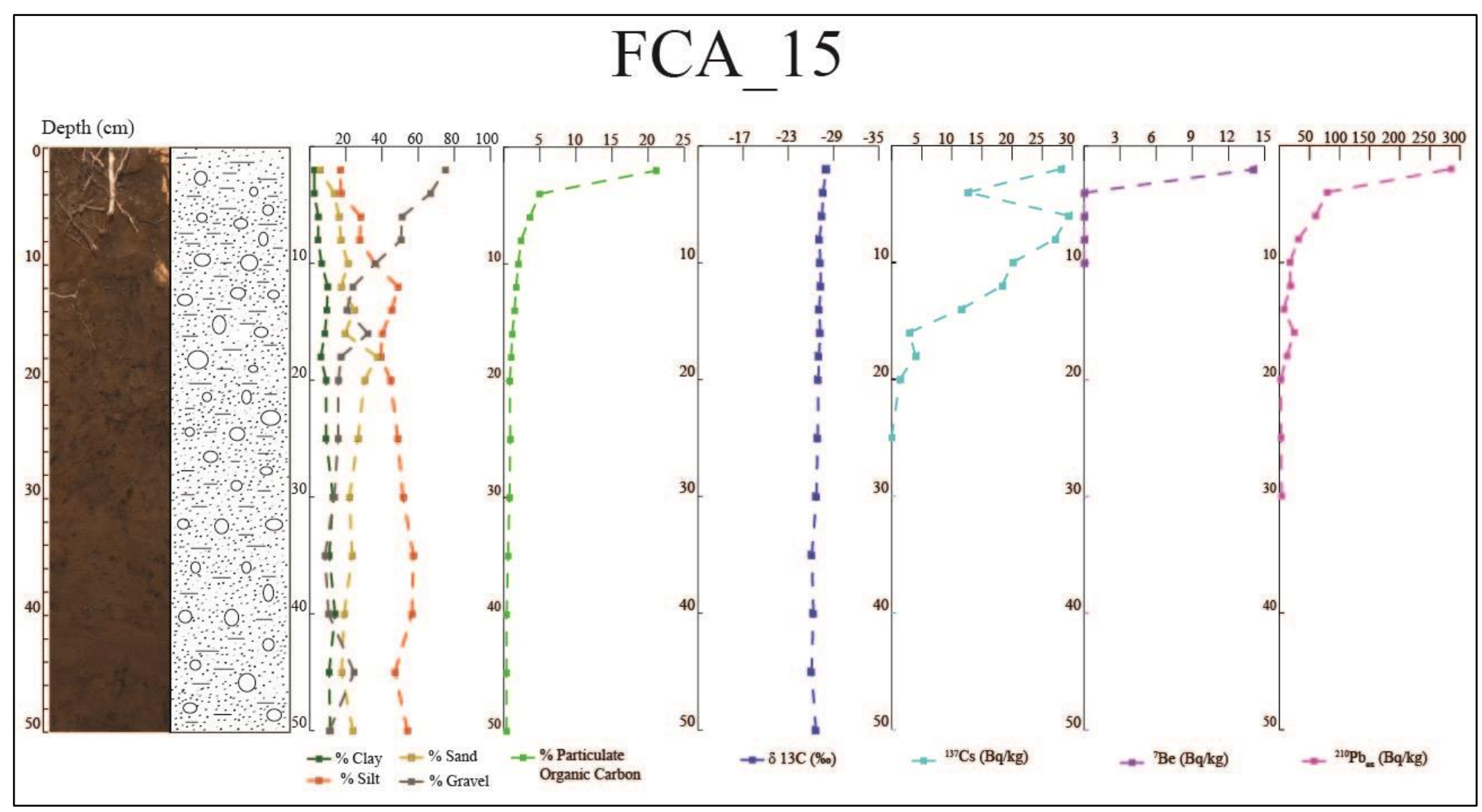




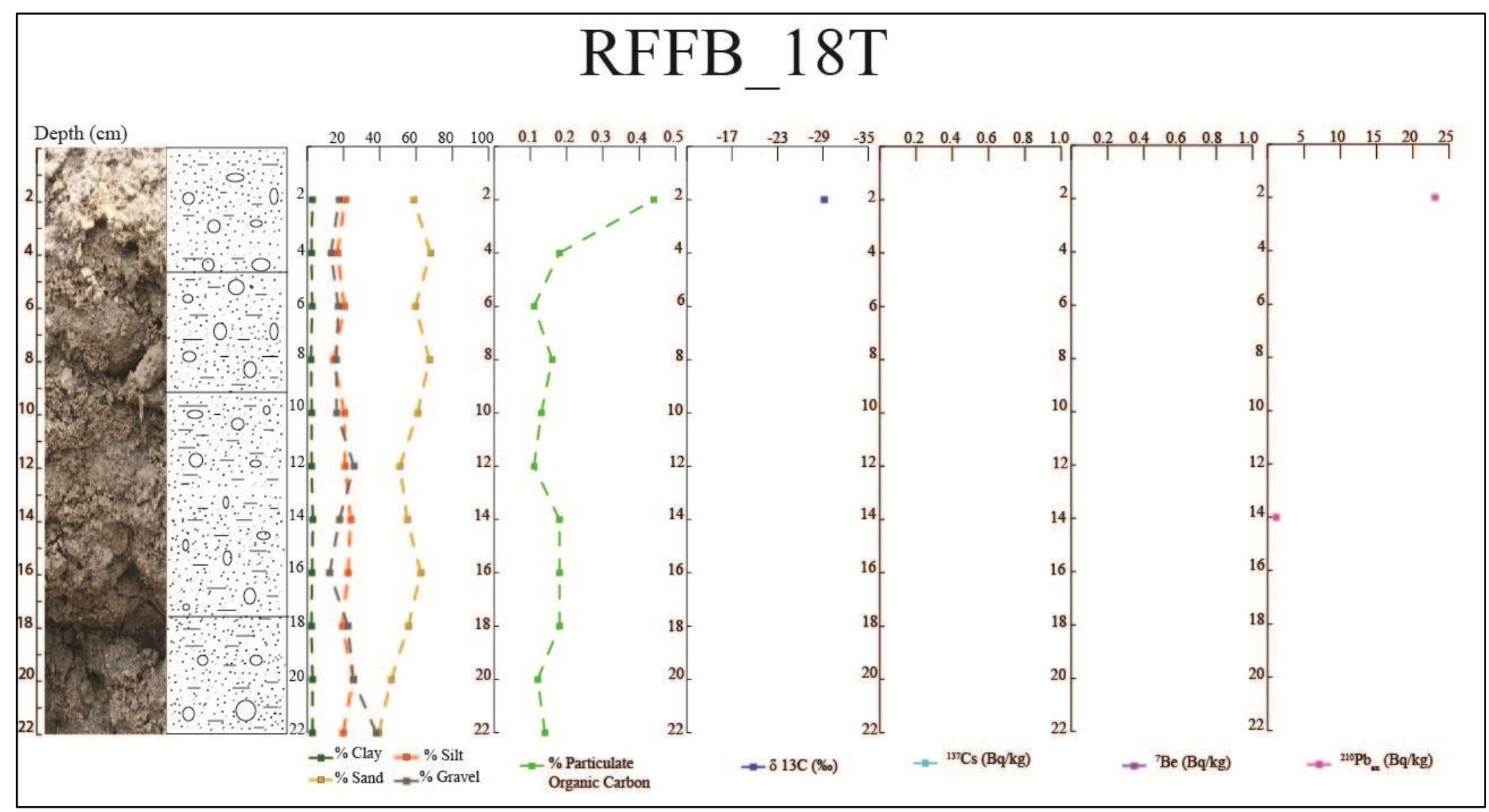




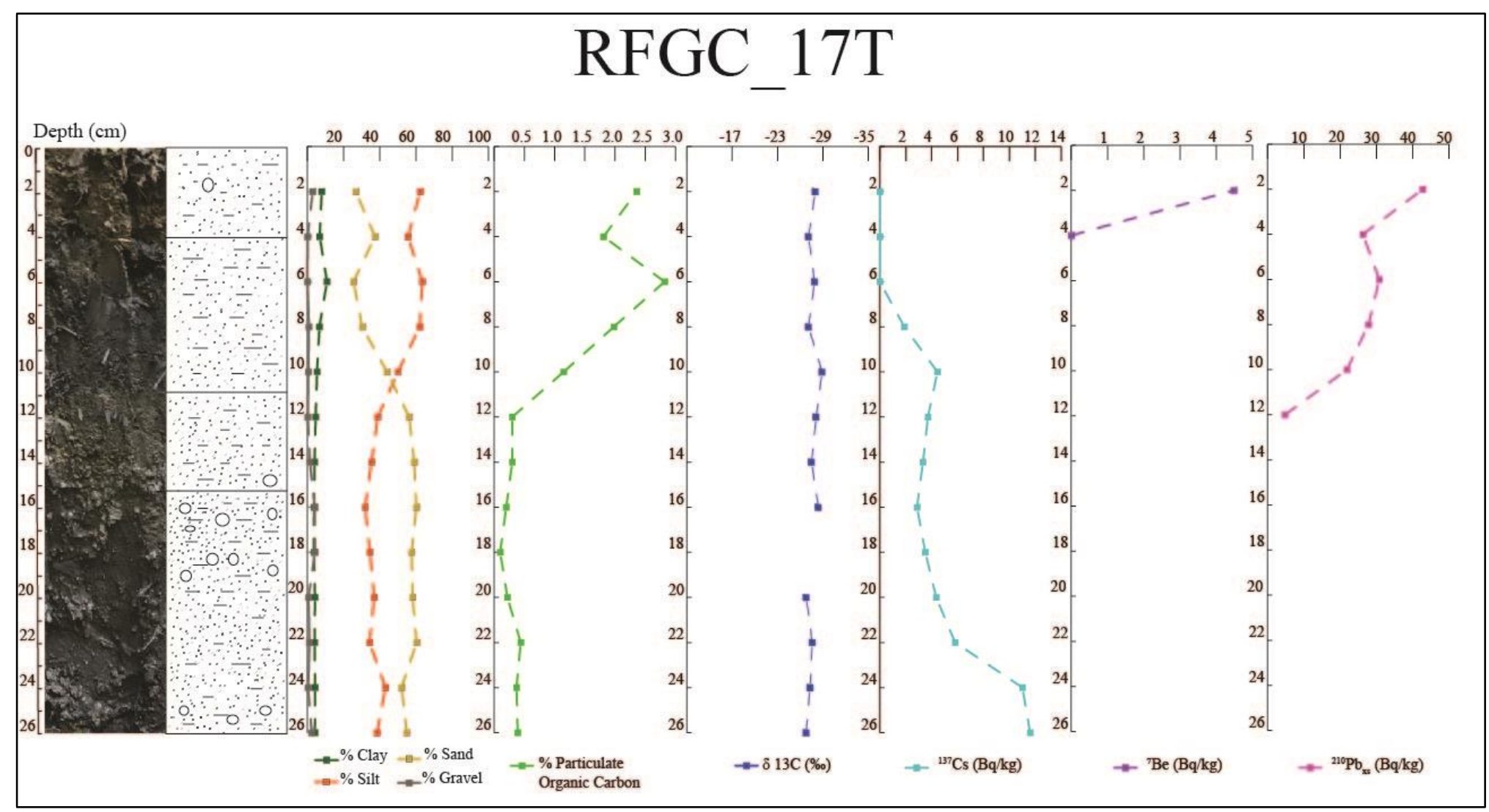




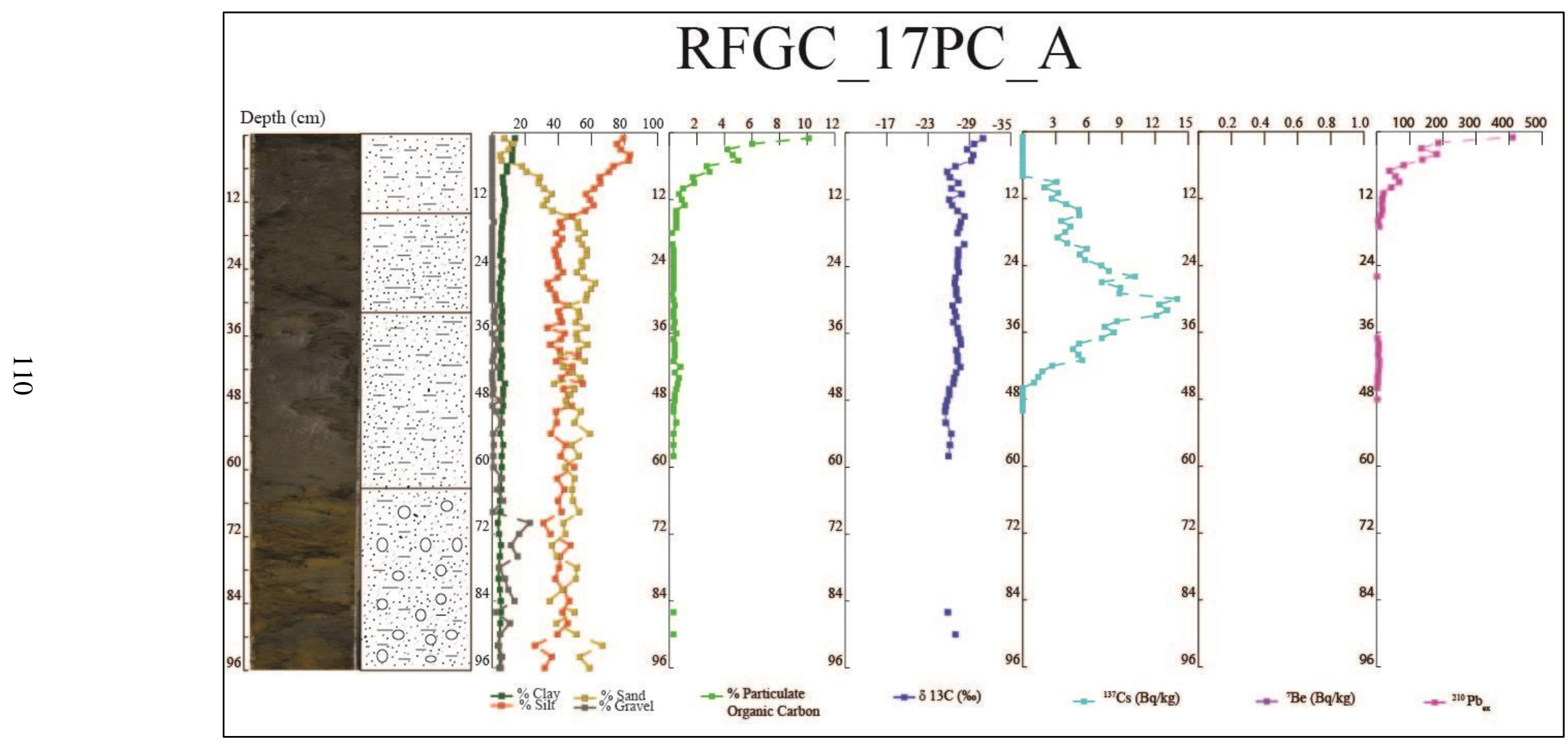




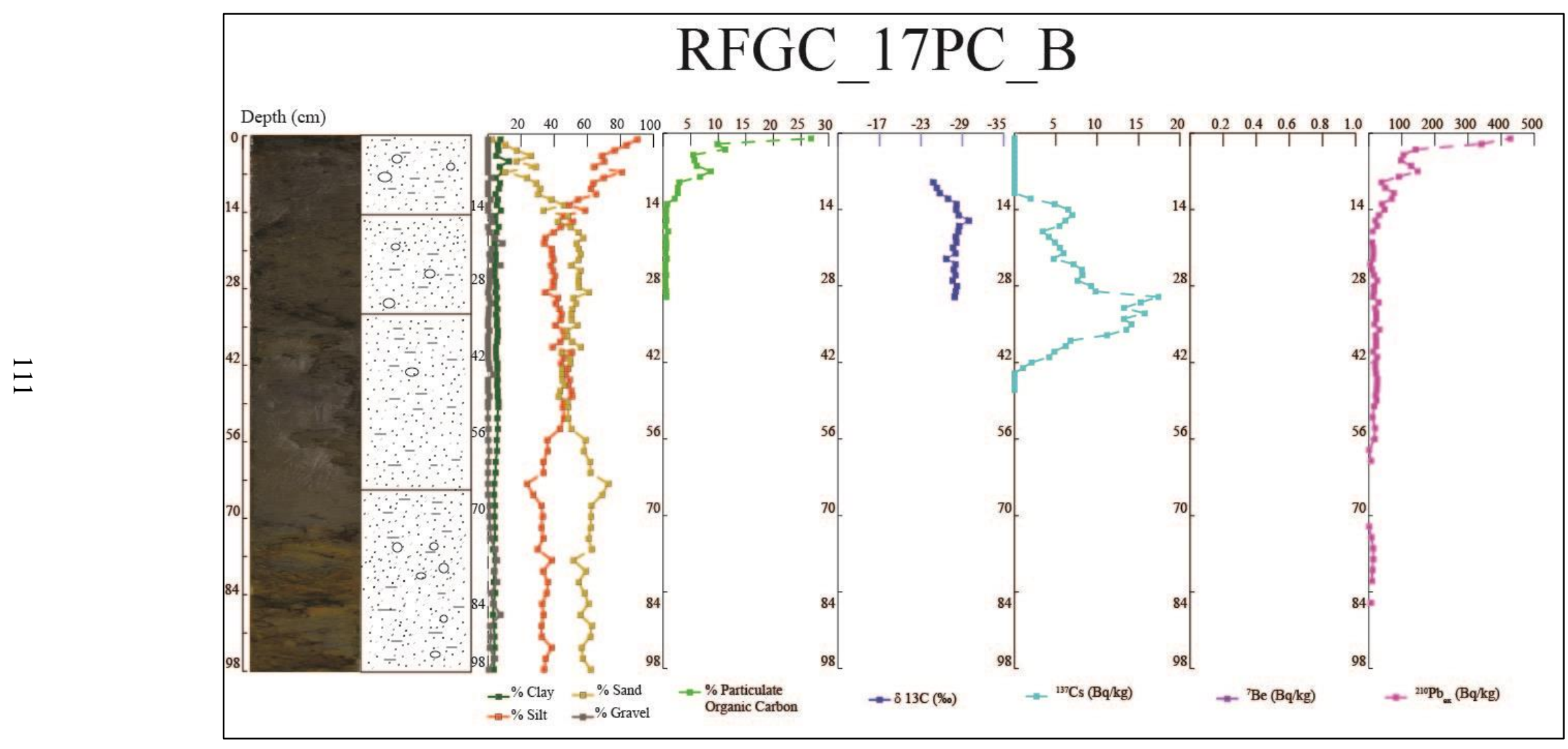




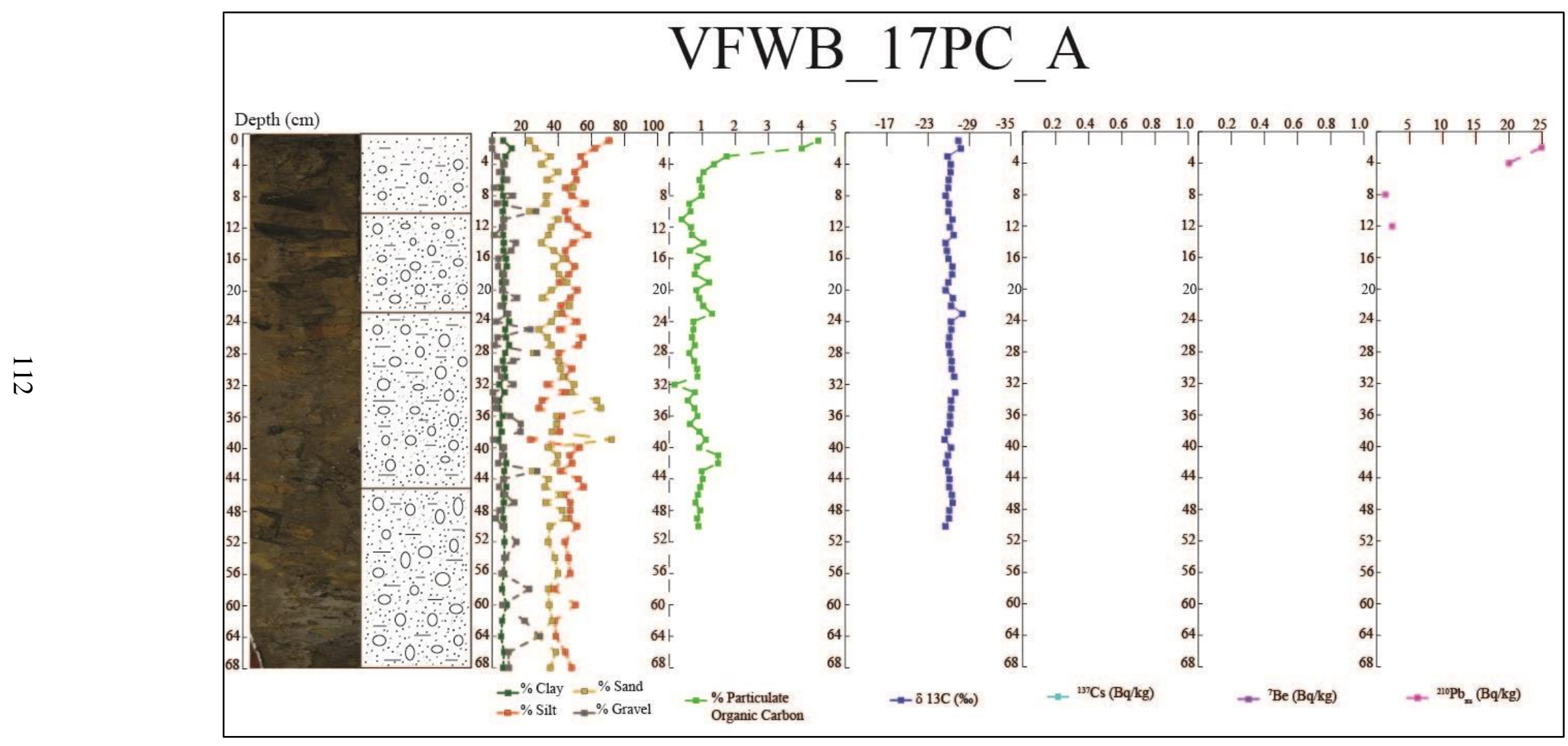




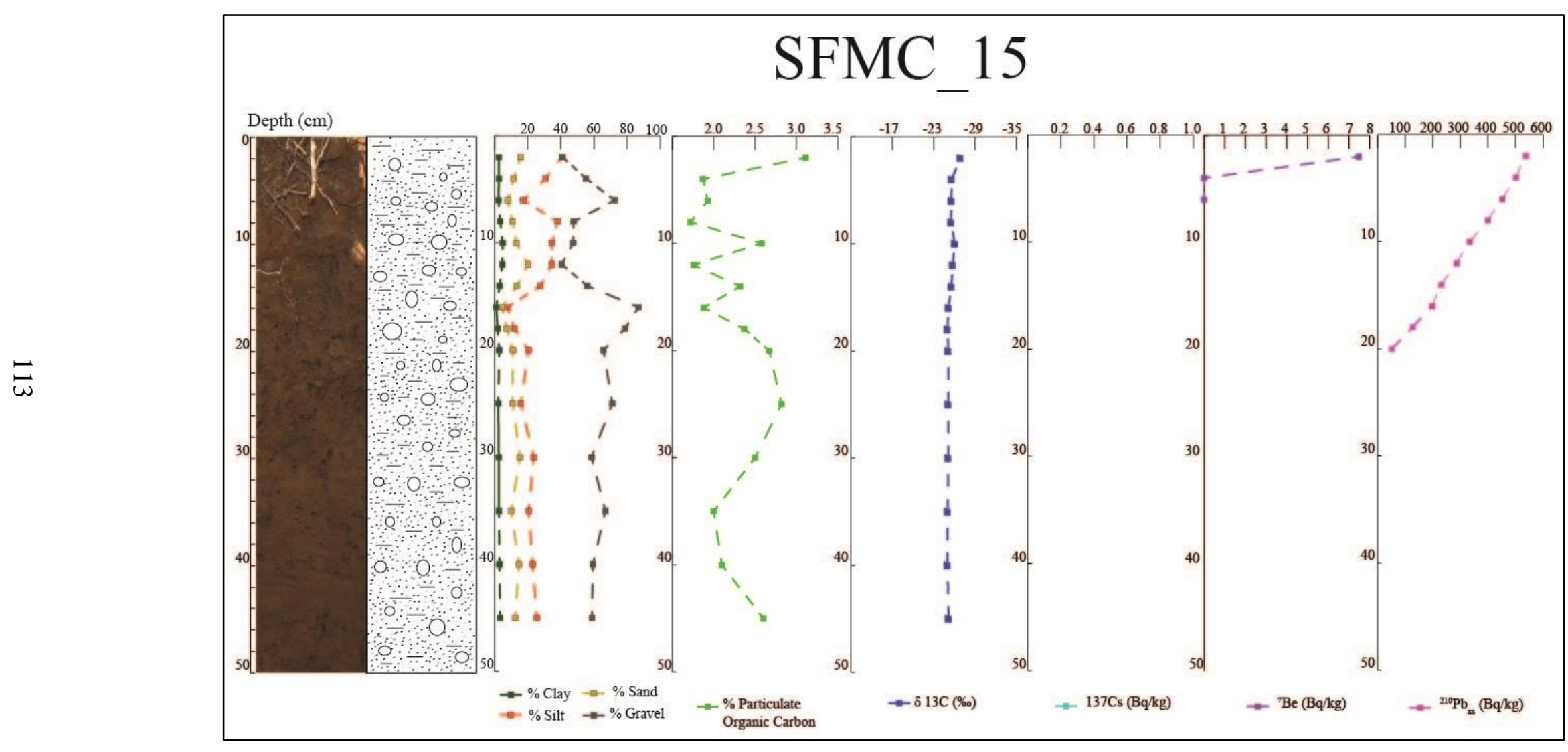




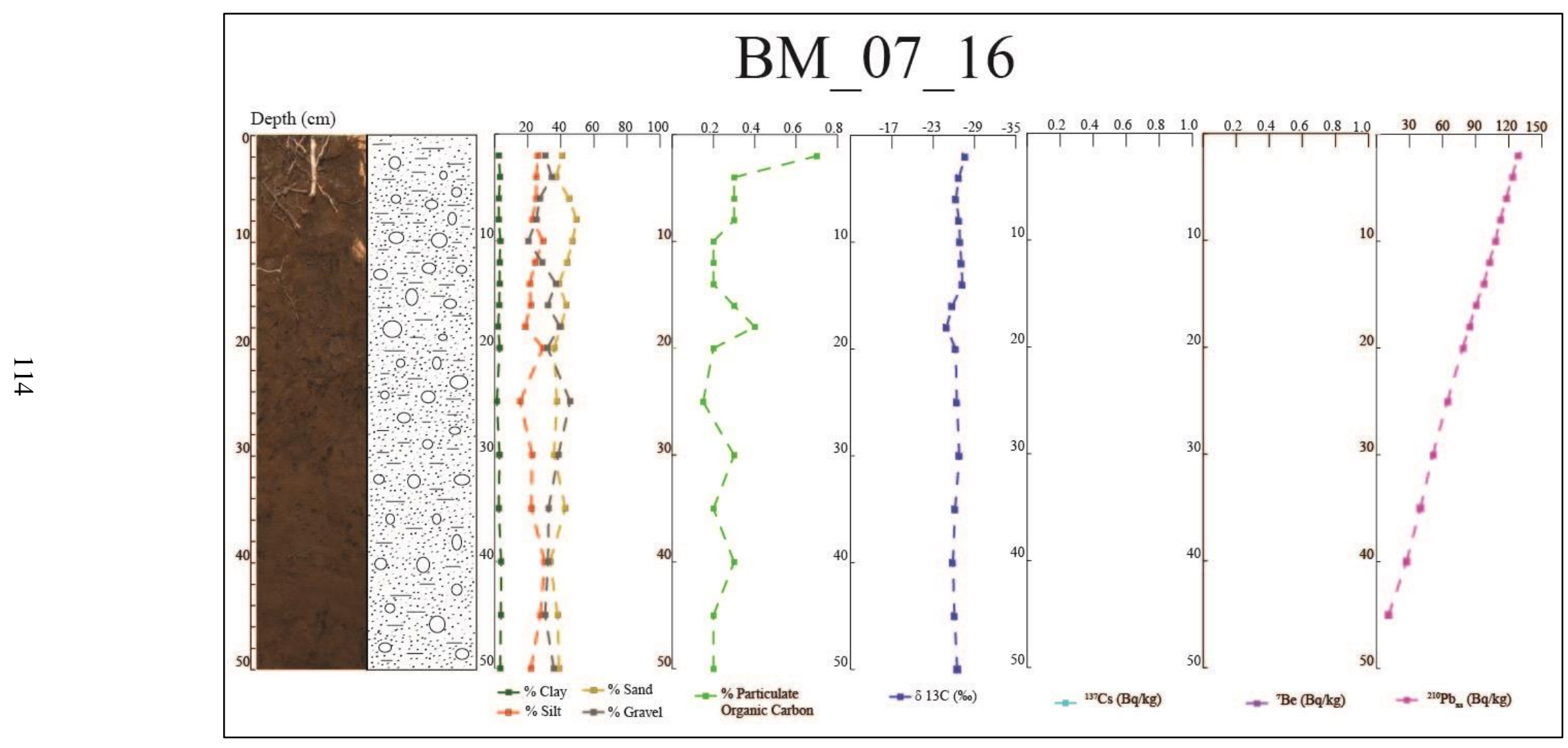




\section{REFERENCES}

Ab Razak, I. A., Li, A., Christensen, E. R. (1996). Association of PAHs, PCBs, ${ }^{137}$ Cs, and ${ }^{210} \mathrm{~Pb}$ with clay, silt, and organic carbon in sediments. Water Science and Technology, 34(7-8), 29-35.

Adams, M. B. (2017). The forestry reclamation approach: Guide to successful reforestation of mined lands. Gen. Tech. Rep. NRS-169. Newtown Square, PA: U.S. Department of Agriculture, Forest Service, Northern Research Station: Volume 169, 128.

Al Hamarneh, I., Wreikat, A., Toukan, K. (2003). Radioactivity concentrations of ${ }^{40} \mathrm{~K}$, ${ }^{134} \mathrm{Cs},{ }^{137} \mathrm{Cs},{ }^{90} \mathrm{Sr},{ }^{241} \mathrm{Am},{ }^{238} \mathrm{Pu}$ and ${ }^{239,240} \mathrm{Pu}$ radionuclides in Jordanian soil samples. J. of Environmental Radioactivity, 67(1), 53-67.

Angel, P. N., Burger, J. A., Davis, V. M., Barton, C. D., Bower, M., Eggerud, S. D., Rothman, P. (2009). The forestry reclamation approach and the measure of its success in Appalachia. In 26th Annual National Conference of the American Society of Mining and Reclamation, Lexington, KY (pp. 18-36).

Angel, P. N., Graves, D. H., Barton, C., Warner, R. C., Conrad, P. W., Sweigard, R. J., Agouridis, C. (2006). Surface mine reforestation research: Evaluation of tree response to low compaction reclamation techniques. In Proceedings, American Society of Mining and Reclamation (pp. 45-58).

Arthur, M. A., Coltharp, G. B., Brown, D. L. (2007). Effects of best management practices on forest stream water quality in eastern Kentucky 1. JAWRA J. of the American Water Resources Association, 34(3), 481-495.

Arvidsson, J. (1999). Nutrient uptake and growth of barley as affected by soil compaction. Plant and Soil, 208(1), 9-19.

Baskaran, M. (Ed.). (2011). Handbook of Environmental Isotope Geochemistry. Springer Science and Business Media. pp 305-331.

Baskaran, M., Coleman, C. H., Santschi, P. H. (1993). Atmospheric depositional fluxes of ${ }^{7} \mathrm{Be}$ and ${ }^{210} \mathrm{~Pb}$ at Galveston and College Station, Texas. J. of Geophysical Research: Atmospheres, 98(D11), 20,555-20,571.

Bauman, J. M., Cochran, C., Chapman, J., Gilland, K. (2015). Plant community development following restoration treatments on a legacy reclaimed mine site. Ecological Engineering, 83, 521-528.

Benmansour, M., Nouira, A., Benkdad, A., MAJAH, M., Bouksirat, H., Oumri, M., Mossadek, R., Duchemin, M. (2011). Estimates of long- and short-term soil erosion rates on farmland in semi-arid West Morocco using caesium-137, excess lead-210 and 
beryllium-7 measurements. Impact of Soil Conservation Measures on Erosion Control and Soil

Quality, IAEA-TECDOC-1665, IAEA, Vienna, 159-174.

Bernhardt, E. S., Palmer, M. A. (2011). The environmental costs of mountaintop mining valley fill operations for aquatic ecosystems of the Central Appalachians. Annals of the New York Academy of Sciences, 1223(1), 39-57.

Bernhardt, E. S., Lutz, B. D., King, R. S., Fay, J. P., Carter, C. E., Helton, A., Campagna, D., Amos, J. (2012). How many mountains can we mine? Assessing the regional degradation of central Appalachian rivers by surface coal mining. Environmental Science and Technology, 46(15), 8,115-8,122.

Bernoux, M., Cerri, C. C., Neill, C., de Moraes, J. F. (1998). The use of stable carbon isotopes for estimating soil organic matter turnover rates. Geoderma, 82(1-3), 43-58.

Beschta, R. L. (1978). Long-term patterns of sediment production following road construction and logging in the Oregon Coast Range. Water Resources Research, 14(6), 1011-1016.

Black, D., McKinnish, T., Sanders, S. (2005a). The economic impact of the coal boom and bust. The Economic Journal, 115(503), 449-476.

Black, D. A., McKinnish, T. G., Sanders, S. G. (2005b). Tight labor markets and the demand for education: Evidence from the coal boom and bust. ILR Review, 59(1), 3-16.

Boccardy, J. A., Spaulding Jr, W. M. (1968). Effects of surface mining on fish and wildlife in Appalachia (No. 65). U.S. Fish and Wildlife Service.

Bohrer, S. L., Limb, R. F., Daigh, A. L. M., Volk, J. M. (2017). Below ground attributes on reclaimed surface mine lands over a 40-year chronosequence. Land Degradation and Development, 28(7), 2,290-2,297.

Bonta, J. V. (2000). Impact of coal surface mining and reclamation on suspended sediment in three Ohio watersheds. JAWRA Journal of the American Water Resources Association, 36(4), 869-887.

Bovis, M. J., Millard, T. H., Oden, M. E. (1998). Gully processes in coastal British Columbia: the role of woody debris. In Carnation Creek and Queen Charlotte Islands Fish/Forestry Workshop: Applying (Vol. 20, pp. 49-76).

Bradshaw, A. D., Chadwick, M. J. (1980). The restoration of land: The ecology and reclamation of derelict and degraded land. University of California Press. 
Brais, S., Camiré, C., Paré, D. (1995). Impacts of whole-tree harvesting and winter windrowing on soil $\mathrm{pH}$ and base status of clayey sites of northwestern Quebec. Canadian J. of Forest Research, 25(6), 997-1,007.

Brown, G. W., Krygier, J. T. (1971). Clear-cut logging and sediment production in the Oregon Coast Range. Water Resources Research, 7(5), 1189-1198.

Burger, J. A. (2011). Sustainable mined land reclamation in the eastern U.S. coalfields: A case for an ecosystem reclamation approach. In Proceedings of the National Meeting of the American Society of Mining and Reclamation, Bismark, ND, USA (Vol. 15, pp. 113141).

Burger, J. A., Zipper, C. E. (2002). How to restore forests on surface-mined land. Publication 460-123. Virginia Cooperative Extension, Virginia Polytechnic Institute and State University.

Cavender, N., Byrd, S., Bechtoldt, C. L., Bauman, J. M. (2014). Vegetation communities of a coal reclamation site in southeastern Ohio. Northeastern Naturalist, 21(1), 31-46.

Clark, E. V., Zipper, C. E. (2016). Vegetation influences near-surface hydrological characteristics on a surface coal mine in eastern USA. Catena, 139, 241-249.

Compton, J. E., Hooker, T. D., Perakis, S. S. (2007). Ecosystem N distribution and $\delta^{15} \mathrm{~N}$ during a century of forest regrowth after agricultural abandonment. Ecosystems, 10(7), $1,197-1,208$.

Crowther, T. W., Maynard, D. S., Leff, J. W., Oldfield, E. E., McCulley, R. L., Fierer, N., Bradford, M. A. (2014). Predicting the responsiveness of soil biodiversity to deforestation: A cross-biome study. Global Change Biology, 20(9), 2,983-2,994.

Curtis, J. B. (2002). Fractured shale-gas systems. AAPG bulletin, 86(11), 1921-1938.

Dawson, T. E., Mambelli, S., Plamboeck, A. H., Templer, P. H., Tu, K. P. (2002). Stable isotopes in plant ecology. Annual Review of Ecology and Systematics, 33(1), 507-559.

Eble, C. F., Hower, J. C. (1997). Coal quality trends and distribution of potentially hazardous trace elements in Eastern Kentucky coals. Fuel, 76(8), 711-715.

Feng, Y., Wang, J., Bai, Z., Reading, L. (2019). Effects of surface coal mining and land reclamation on soil properties: A review. Earth-Science Reviews.

Ferrari, J. R., Lookingbill, T. R., McCormick, B., Townsend, P. A., Eshleman, K. N. (2009). Surface mining and reclamation effects on flood response of watersheds in the central Appalachian Plateau region. Water Resources Research, 45(4), W04407, doi:10.1029/ 2008WR007109. 
Foil, R. R., Ralston, C. W. (1967). The establishment and growth of Loblolly Pine seedlings on compacted soils 1. Soil Science Society of America J., 31(4), 565-568.

Fornara, D. A., Tilman, D. (2008). Plant functional composition influences rates of soil carbon and nitrogen accumulation. J. of Ecology, 96(2), 314-322.

Fox, J. F. (2009). Identification of sediment sources in forested watersheds with surface coal mining disturbance using Carbon and Nitrogen isotopes 1. JAWRA J. of the American Water Resources Association, 45(5), 1,273-1,289.

Foufoula-Georgiou, E., Ganti, V., \& Dietrich, W. E. (2010). A nonlocal theory of sediment transport on hillslopes. J. of Geophysical Research: Earth Surface, 115(F2).

Fritz, K. M., Fulton, S., Johnson, B. R., Barton, C. D., Jack, J. D., Word, D. A., Burke, R. A. (2010). Structural and functional characteristics of natural and constructed channels draining a reclaimed mountaintop removal and valley fill coal mine. J. of the North American Benthological Society, 29(2), 673-689.

Goldberg, E. F., Power, G. (1972). Legal problems of coal mine reclamation: A study in Maryland, Ohio, Pennsylvania, and West Virginia. College Park, MD.

Gomez, A., Powers, R. F., Singer, M. J., Horwath, W. R. (2002). Soil compaction effects on growth of young ponderosa pine following litter removal in California's Sierra Nevada. Soil Science Society of America J., 66(4), 1,334-1,343.

Gough, D. B. (2013). The value of the commonwealth: An ecocritical history of Robinson Forest. Ph.D. Dissertation, The University of Iowa.

Greacen, E. L., Sands, R. (1980). Compaction of forest soils. A review. Soil Research, 18(2), 163-189.

Groninger, J., Skousen, J., Angel, P., Barton, C., Burger, J., Zipper, C. (2007). Mine reclamation practices to enhance forest development through natural succession. In: Adams, Mary Beth, ed. The Forestry Reclamation Approach: Guide to Successful Reforestation of Mined Lands. Gen. Tech. Rep. NRS-169. Newtown Square, PA: U.S. Department of Agriculture, Forest Service, Northern Research Station: 1-7.

Haering, K. C., Daniels, W. L., Galbraith, J. M. (2004). Appalachian mine soil morphology and properties. Soil Science Society of America J., 68(4), 1,315-1,325.

Hamlett, J. M., Melvin, S. W., Horton, R. (1990). Traffic and soil amendment effects on infiltration and compaction. Transactions of the ASAE, 33(3), 821-826.

Hamza, M. A., Anderson, W. K. (2005). Soil compaction in cropping systems: A review of the nature, causes and possible solutions. Soil and Tillage Research, 82(2), 121-145. 
Harrison, L. H., Klotter, J. C. (2009). A new history of Kentucky. University Press of Kentucky.

Hatten, J. A., Segura, C., Bladon, K. D., Hale, V. C., Ice, G. G., Stednick, J. D. (2018). Effects of contemporary forest harvesting on suspended sediment in the Oregon Coast Range: Alsea Watershed Study Revisited. Forest Ecology and Management, 408, 238248.

He, Q., Walling, D. E. (1996). Interpreting particle size effects in the adsorption of ${ }^{137} \mathrm{Cs}$ and unsupported ${ }^{210} \mathrm{~Pb}$ by mineral soils and sediments. J. of Environmental Radioactivity, 30(2), 117-137.

Hillier, S. (2001). Particulate composition and origin of suspended sediment in the R. Don, Aberdeenshire, UK. Science of the Total Environment, 265(1-3), 281-293.

Hobbie, E. A., Werner, R. A. (2004). Intramolecular, compound-specific, and bulk carbon isotope patterns in $\mathrm{C} 3$ and $\mathrm{C} 4$ plants: A review and synthesis. New Phytologist, 161(2), 371-385.

Holl, K. D. (2002). Long-term vegetation recovery on reclaimed coal surface mines in the eastern USA. J. Applied Ecology, 39(6), 960-970.

Holl, K. D., Cairns Jr, J. (1994). Vegetational community development on reclaimed coal surface mines in Virginia. Bulletin of the Torrey Botanical Club, 327-337.

Huang, J., Lacey, S. T., Ryan, P. J. (1996). Impact of forest harvesting on the hydraulic properties of surface soil. Soil Science, 161(2), 79-86.

Huffman, G. P., Mitra, S., Huggins, F. E., Shah, N., Vaidya, S., Lu, F. (1991).

Quantitative analysis of all major forms of sulfur in coal by X-ray absorption fine structure spectroscopy. Energy and Fuels, 5(4), 574-581.

Hunter, C. D., Young, D. M. (1953). Relationship of natural gas occurrence and production in eastern Kentucky (Big Sandy gas field) to joints and fractures in Devonian bituminous shale. AAPG Bulletin, 37(2), 282-299.

Jaeger, K. L. (2015). Reach-scale geomorphic differences between headwater streams draining mountaintop mined and unmined catchments. Geomorphology, 236, 25-33.

Jobbágy, E. G., Jackson, R. B. (2000). The vertical distribution of soil organic carbon and its relation to climate and vegetation. Ecological applications, 10(2), 423-436.

Kalisz, P. J., Dotson, D. B. (1989). Land-use history and the occurrence of exotic earthworms in the mountains of eastern Kentucky. American Midland Naturalist, 122(2), 288-297. 
Kohn, M. J. (2010). Carbon isotope compositions of terrestrial C3 plants as indicators of (paleo) ecology and (paleo) climate. Proceedings of the National Academy of

Sciences, 107(46), 19,691-19,695.

Krishnaswami, S., Benninger, L. K., Aller, R. C., Von Damm, K. L. (1980).

Atmospherically-derived radionuclides as tracers of sediment mixing and accumulation in near-shore marine and lake sediments: Evidence from ${ }^{7} \mathrm{Be},{ }^{210} \mathrm{~Pb}$, and ${ }^{239,240} \mathrm{Pu}$. Earth and Planetary Science Letters, 47(3), 307-318.

Kochenderfer, J. N. (1970). Erosion control on logging roads in the Appalachians. Res. Pap. NE-158. Upper Darby, PA: US Department of Agriculture, Forest Service, Northeastern Forest Experiment Station. 28 p., 158.

Koestner, K. A., Carroll, M. D., Neary, D. G., Koestner, P. E., Youberg, A. (2011). Depositional characteristics and sediment availability resulting from the post-Schultz Fire floods of 2010. 24th Annual Symposium of the Arizona Hydrological Society; Watersheds Near and Far: Response to Changes in Climate and Landscape; September 18-20, 2010; Flagstaff, AZ. 5 p.

Kozlowski, T. T. (1999). Soil compaction and growth of woody plants. Scandinavian J. of Forest Research, 14(6), 596-619.

Larsen, R. J. (1984). Worldwide deposition of 90 Sr through 1982 (No. EML--430). Department of Energy.

Lima, A. T., Mitchell, K., O’Connell, D. W., Verhoeven, J., Van Cappellen, P. (2016). The legacy of surface mining: Remediation, restoration, reclamation and rehabilitation. Environmental Science and Policy, 66, 227-233.

Lubis, A. A. (2013). Constant rate of supply (CRS) model for determining the sediment accumulation rates in the coastal area using ${ }^{210} \mathrm{~Pb}$. J. of Coastal Development, 10(1), 918.

Mabit, L., Benmansour, M., Walling, D. E. (2008). Comparative advantages and limitations of the fallout radionuclides ${ }^{137} \mathrm{Cs},{ }^{210} \mathrm{~Pb}$ ex and ${ }^{7} \mathrm{Be}$ for assessing soil erosion and sedimentation. J. of Environmental Radioactivity, 99(12), 1,799-1,807.

Maharaj, S., Barton, C. D., Karathanasis, T. A., Rowe, H. D., Rimmer, S. M. (2007). Distinguishing" new" from" old" organic carbon in reclaimed coal mine sites using thermogravimetry: II. Field validation. Soil science, 172(4), 302-312.

Mangena, S. J., Brent, A. C. (2006). Application of a life cycle impact assessment framework to evaluate and compare environmental performances with economic values of supplied coal products. Journal of Cleaner Production, 14(12-13), 1,071-1,084. 
Martin, C. W. (1988). Soil disturbance by logging in New England, review and management recommendations. Northern J. of Applied Forestry, 5(1), 30-34.

Martin, C. W., Hornbeck, J. W. (1994). Logging in New England need not cause sedimentation of streams. Northern J. of Applied Forestry, 11(1), 17-23.

Martin, L. L. (2006). Effects of Forest and Grass Vegetation on Fluviokarst Hillslope Hydrology. Bowman's Bend, Kentucky (Ph.D. dissertation) University of Kentucky, Lexington (Available at: http://uknowledge.uky. edu/gradschool_diss/362/).

Matisoff, G., Bonniwell, E. C., Whiting, P. J. (2002). Soil erosion and sediment sources in an Ohio watershed using beryllium-7, cesium-137, and lead-210. J. of Environmental Quality, 31(1), 54-61.

Megahan, W. F., \& Kidd, W. J. (1972). Effects of logging and logging roads on erosion and sediment deposition from steep terrain. Journal of Forestry, 70(3), 136-141.

McCashion, J. D., \& Rice, R. M. (1983). Erosion on logging roads in northwestern California: How much is avoidable?. Journal of Forestry, 81(1), 23-26.

Meier, A. J., Bratton, S. P., Duffy, D. C. (1995). Possible ecological mechanisms for loss of vernal-herb diversity in logged eastern deciduous forests. Ecological Applications, 5(4), 935-946.

Mensah, A. K. (2015). Role of revegetation in restoring fertility of degraded mined soils in Ghana: A review. International J. of Biodiversity and Conservation, 7(2), 57-80.

Milici, R. C. (2000). Depletion of Appalachian coal reserves-how soon? International Journal of Coal Geology, 44(3-4), 251-266.

Miura, T., Hayano, K., Nakayama, K. (1999). Determination of ${ }^{210} \mathrm{~Pb}$ and ${ }^{210} \mathrm{Po}$ in environmental samples by alpha ray spectrometry using an extraction chromatographic resin. Analytical Sciences, 15(1), 23-28.

Moehring, D. M., Rawls, I. W. (1970). Detrimental effects of wet weather logging. J. of Forestry, 68(3), 166-167.

Narita, H., Harada, K., Burnett, W. C., Tsunogai, S., McCabe, W. J. (1989).

Determination of ${ }^{210} \mathrm{~Pb},{ }^{210} \mathrm{Bi}$ and ${ }^{210} \mathrm{Po}$ in natural waters and other materials by electrochemical separation. Talanta, 36(9), 925-929.

O'Leary, M. H. (1988). Carbon isotopes in photosynthesis. Bioscience, 38(5), 328-336.

O'loughlin, C. L., Pearce, A. J. (1976). Influence of Cenozoic geology on mass movement and sediment yield response to forest removal, North Westland, New Zealand. Bulletin of the International Association of Engineering Geology 13(1), 41-46. 
O'Loughlin, C. L., Rowe, L. K., Pearce, A. J. (1980). Sediment yield and water quality responses to clear felling of evergreen mixed forests in western New Zealand. IAHSAISH Publication (IAHS). no. 130.

O'Loughlin, C. L., Rowe, L. K., Pearce, A. J. (1982). Exceptional storm influences on slope erosion and sediment yield in small forest catchments, North Westland, New Zealand. Institution of Engineers, Australia.

Palmer, M. A., Bernhardt, E. S., Schlesinger, W. H., Eshleman, K. N., FoufoulaGeorgiou, E., Hendryx, M., Lemly, A., Likens, G., Loucks, O., Power, M., White, P., Wilcock, P. (2010). Mountaintop mining consequences. Science, 327(5962), 148-149.

Persson, B. R., Holm, E. (2011). Polonium-210 and lead-210 in the terrestrial environment: A historical review. J. of Environmental Radioactivity, 102(5), 420-429.

Peterson, B. J., Fry, B. (1987). Stable isotopes in ecosystem studies. Annual Review of Ecology and Systematics, 18(1), 293-320.

Phillips, J. D. (2004). Impacts of surface mine valley fills on headwater floods in eastern Kentucky. Environmental Geology, 45(3), 367-380.

Phillips, D. L., Gregg, J. W. (2001). Uncertainty in source partitioning using stable isotopes. Oecologia, 127(2), 171-179.

Plouffe, A., Hall, G. E., Pelchat, P. (2001). Leaching of loosely bound elements during wet grain size separation with sodium hexametaphosphate: Implications for selective extraction analysis. Geochemistry: Exploration, Environment, Analysis, 1(2), 157-162.

Poet, S. E., Moore, H. E., Martell, E. A. (1972). Lead 210, bismuth 210, and polonium 210 in the atmosphere: Accurate ratio measurement and application to aerosol residence time determination. J. of Geophysical Research, 77(33), 6,515-6,527.

Pond, G. J. (2010). Patterns of Ephemeroptera taxa loss in Appalachian headwater streams (Kentucky, USA). Hydrobiologia, 641(1), 185-201.

Pond, G. J., Passmore, M. E., Pointon, N. D., Felbinger, J. K., Walker, C. A., Krock, K. J., Fulton, J. B., Nash, W. L. (2014). Long-term impacts on macroinvertebrates downstream of reclaimed mountaintop mining valley fills in central Appalachia. Environmental Management, 54(4), 919-933.

Price, P., Wright, I. A. (2016). Water quality impact from the discharge of coal mine wastes to receiving streams: Comparison of impacts from an active mine with a closed mine. Water, Air, and Soil Pollution, 227(5), 155

Price, S. J., Muncy, B. L., Bonner, S. J., Drayer, A. N., Barton, C. D. (2016). Effects of 
mountaintop removal mining and valley filling on the occupancy and abundance of stream salamanders. J. of Applied Ecology, 53(2), 459-468.

Ramani, R. V. (2012). Surface mining technology: progress and prospects. Procedia Engineering, 46, 9-21.

Rani, L. M., Jeevanram, R. K., Kannan, V., Govindaraju, M. (2014). Estimation of Polonium-210 activity in marine and terrestrial samples and computation of ingestion dose to the public in and around Kanyakumari coast, India. J. of Radiation Research and Applied Sciences, 7(2), 207-213.

Reisinger, T. W., Simmons, G. L., Pope, P. E. (1988). The impact of timber harvesting on soil properties and seedling growth in the south. Southern J. of Applied Forestry, 12(1), 58-67.

Rice, D. L. (1986). Early diagenesis in bioadvective sediments: Relationships between the diagenesis of beryllium-7, sediment reworking rates, and the abundance of conveyorbelt deposit-feeders. J. of Marine Research, 44(1), 149-184.

Rice, R. M., Tilley, F. B., Datzman, P. A. (1979). A watershed's response to logging and roads: South Fork of Caspar Creek, California, 1967-1976. Res. Paper PSW-RP-146. Berkeley, CA: US Department of Agriculture, Forest Service, Pacific Southwest Forest and Range Experiment Station. 12 p, 146.

Ritchie, J. C., McHenry, J. R. (1990). Application of radioactive fallout cesium-137 for measuring soil erosion and sediment accumulation rates and patterns: A review. $J$. of Environmental Quality, 19(2), 215-233.

Robinson, R. A., Slingerland, R. L. (1998). Origin of fluvial grain-size trends in a foreland basin: The Pocono Formation on the central Appalachian basin. J. of Sedimentary Research, 68(3), 473-486.

Ryan, M., Meiman, J. (1996). An examination of short-term variations in water quality at a karst spring in Kentucky. Groundwater, 34(1), 23-30.

Santschi, P. H., Guo, L., Walsh, I. D., Quigley, M. S., Baskaran, M. (1999). Boundary exchange and scavenging of radionuclides in continental margin waters of the Middle Atlantic Bight: Implications for organic carbon fluxes. Continental Shelf Research, 19(5), 609-636.

Santschi, P. H., Allison, M. A., Asbill, S., Perlet, A. B., Cappellino, S., Dobbs, C., McShea, L. (1999). Sediment transport and $\mathrm{Hg}$ recovery in Lavaca Bay, as evaluated from radionuclide and $\mathrm{Hg}$ distributions. Environmental Science and Technology, 33(3), 378-391. 
Schuler, R., Lowery, B., Wolkowski, R., Bundy, L. (1986). Soil Compaction: Causes, Concerns, and Cures. University of Wisconsin-Extension Report A3367.

Schuler, T. M., Gillespie, A. R. (2000). Temporal patterns of woody species diversity in a central Appalachian forest from 1856 to 1997. J. of the Torrey Botanical Society, 127(2), 149-161.

Sharma, P., Gardner, L. R., Moore, W. S., Bollinger, M. S. (1987). Sedimentation and bioturbation in a salt marsh as revealed by ${ }^{210} \mathrm{~Pb},{ }^{137} \mathrm{Cs}$, and ${ }^{7} \mathrm{Be}$ studies. Limnology and Oceanography, 32(2), 313-326.

Shaw III, C. G., Sidle, R. C., Harris, A. S. (1987). Evaluation of planting sites common to a southeast Alaska clear-cut. III. Effects of microsite type and ectomycorrhizal inoculation on growth and survival of Sitka spruce seedlings. Canadian J. of Forest Research, 17(4), 334-339.

Sheoran, V., Sheoran, A. S., Poonia, P. (2010). Soil reclamation of abandoned mine land by revegetation: A review. International J. of Soil, Sediment and Water, 3(2), art. 13.

Simmons, J. A., Currie, W. S., Eshleman, K. N., Kuers, K., Monteleone, S., Negley, T. L., Pohlad, B.R, Thomas, C. L. (2008). Forest to reclaimed mine land use change leads to altered ecosystem structure and function. Ecological Applications, 18(1), 104-118.

Stevenson, B. A., Kelly, E. F., McDonald, E. V., Busacca, A. J. (2005). The stable carbon isotope composition of soil organic carbon and pedogenic carbonates along a bioclimatic gradient in the Palouse region, Washington State, USA. Geoderma, 124(1-2), 37-47.

Swab, R. M., Lorenz, N., Byrd, S., Dick, R. (2017). Native vegetation in reclamation: Improving habitat and ecosystem function through using prairie species in mine land reclamation. Ecological Engineering, 108, 525-536.

Swer, S., Singh, O. P. (2004). Status of water quality in coal mining areas of Meghalaya, India. In Proceedings of the national seminar on environmental engineering with special emphasis on mining environment (pp. 19-20). NSEEME-2004.

Tiwary, R. K. (2001). Environmental impact of coal mining on water regime and its management. Water, Air, and Soil Pollution, 132(1-2), 185-199.

Turekian, K. K., Nozaki, Y., Benninger, L. K. (1977). Geochemistry of atmospheric radon and radon products. Annual Review of Earth and Planetary Sciences, 5(1), 227255.

Updegraff, K., Pastor, J., Bridgham, S. D., Johnston, C. A. (1995). Environmental and substrate controls over carbon and nitrogen mineralization in northern wetlands. Ecological Applications, 5(1), 151-163. 
Ussiri, D. A., Lal, R. (2005). Carbon sequestration in reclaimed minesoils. Critical Reviews in Plant Sciences, 24(3), 151-165.

Ussiri, D. A., Lal, R., Jacinthe, P. A. (2006). Post-reclamation land use effects onproperties and carbon sequestration in minesoils of southeastern Ohio. Soil Science, 171(3), 261-271.

Vaaramaa, K., Aro, L., Solatie, D., Lehto, J. (2010). Distribution of ${ }^{210} \mathrm{~Pb}$ and ${ }^{210} \mathrm{Po}$ in boreal forest soil. Science of the Total Environment, 408(24), 6,165-6,171.

Vesterbacka, P., Ikäheimonen, T. K. (2005). Optimization of ${ }^{210} \mathrm{~Pb}$ determination via spontaneous deposition of ${ }^{210} \mathrm{Po}$ on a silver disk. Analytica Chimica Acta, 545(2), 252261.

Walling, D. E. (1998). Use of 137 Cs and other fallout radionuclide in soil erosion investigations: progress, problems and prospects (No. IAEA-TECDOC--1028).

Walling, D. E., Zhang, Y., He, Q. (2011). Models for deriving estimates of erosion and deposition rates from fallout radionuclide (caesium-137, excess lead-210, and beryllium7) measurements and the development of user-friendly software for model implementation. Impact of soil conservation measures on erosion control and soil quality. IAEA-TECDOC-1665, 11-33.

Wan, G. J., Chen, J. A., Wu, F. C., Xu, S. Q., Bai, Z. G., Wan, E. Y. Wang, C. S., Huang, R. G., Yeager, K. M. Santschi, P. H. (2005). Coupling between ${ }^{210} \mathrm{~Pb}$ ex and organic matter in sediments of a nutrient-enriched lake: An example from Lake Chenghai, China. Chemical Geology, 224(4), 223-236.

Wang, J., LeDoux, C. B., Edwards, P., Jones, M. (2005). Soil bulk density changes caused by mechanized harvesting: A case study in central Appalachia. Forest Products J., 55 (11):

$37-40$.

Wentworth, C. K. (1922). A scale of grade and class terms for clastic sediments. The J. of Geology, 30(5), 377-392.

Wickham, J. D., Riitters, K. H., Wade, T. G., Coan, M., Homer, C. (2007). The effect of Appalachian mountaintop mining on interior forest. Landscape Ecology, 22(2), 179-187.

Wickham, J., Wood, P. B., Nicholson, M. C., Jenkins, W., Druckenbrod, D., Suter, G., Strager, M., Mazzarella, C., Galloway, W., Amos, J. (2013). The overlooked terrestrial impacts of mountaintop mining. BioScience, 63(5), 335-348.

Wood, P. J., \& Armitage, P. D. (1997). Biological effects of fine sediment in the lotic environment. Environmental management, 21(2), 203-217. 
Wyatt, J. L., Silman, M. R. (2010). Centuries-old logging legacy on spatial and temporal patterns in understory herb communities. Forest Ecology and Management, 260(1), 116124.

Wynn, J. G., Harden, J. W., Fries, T. L. (2006). Stable carbon isotope depth profiles and soil organic carbon dynamics in the lower Mississippi Basin. Geoderma, 131(1-2), 89109.

Yang, M. Y., Walling, D. E., Tian, J. L., Liu, P. L. (2006). Partitioning the contributions of sheet and rill erosion using beryllium-7 and cesium-137. Soil Science Society of America Journal, 70(5), 1579-1590.

Yeager, K. M., Santschi, P. H., Phillips, J. D., Herbert, B. E. (2005). Suspended sediment sources and tributary effects in the lower reaches of a coastal plain stream as indicated by radionuclides, Loco Bayou, Texas. Environmental Geology, 47(3), 382-395.

Yeager, K. M., Santschi, P. H., Rifai, H. S., Suarez, M. P., Brinkmeyer, R., Hung, C., Schindler, K., Andres, M., Weaver, E. (2007). Dioxin chronology and fluxes in sediments of the Houston Ship Channel, Texas: Influences of non-steady-state sediment transport and total organic carbon. Environmental Science and Technology, 41(15), 5,291-5,298.

Zipper, C. E., Burger, J. A., Skousen, J. G., Angel, P. N., Barton, C. D., Davis, V., Franklin, J. A. (2011). Restoring forests and associated ecosystem services on Appalachian coal surface mines. Environmental Management, 47(5), 751-765. 
VITA

\section{William Edward Bond}

\section{Education}

B.S. Natural Resource Management (2014)

Angelo State University

B.S. Geology (2016)

Angelo State University

Experience

Shale Oil Research Fellow

Angelo State University

Graduate Teaching Assistant

Department of Earth and Environmental Sciences

Research Assistant

Department of Earth and Environmental Sciences 